\title{
Análise de Riscos Costeiros a Eventos Atmosféricos Extremos no Litoral Sul do Estado de São Paulo - Estudo de caso na região da Desembocadura de Cananéia
}

Dissertação apresentada ao Instituto Oceanográfico da Universidade de São Paulo, como parte dos requisitos para obtenção do título de Mestre em Ciências, área de Oceanografia Geológica

Orientador: Prof. Dr. Moysés Gonsalez Tessler

São Paulo 


\section{Universidade de São Paulo \\ Instituto Oceanográfico}

Análise de Riscos Costeiros a Eventos Atmosféricos Extremos no Litoral Sul do Estado de São Paulo - Estudo de caso na região da Desembocadura lagunar de Cananéia

Dissertação apresentada ao Instituto Oceanográfico da Universidade de São Paulo, como parte dos requisitos para obtenção do título de Mestre em Ciências, área de Oceanografia Geológica

Julgada em

Conceito

$\operatorname{Prof}(a) \cdot \operatorname{Dr}(a)$.

Conceito

$\operatorname{Prof}(\mathrm{a}) . \operatorname{Dr}(\mathrm{a})$.

Conceito

Prof(a). Dr(a). 


\section{Sumário}

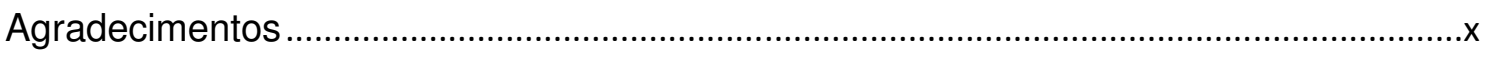

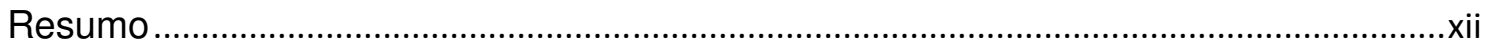

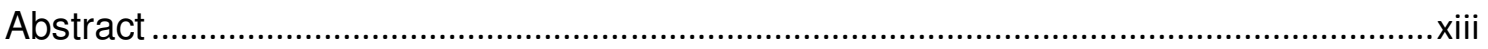

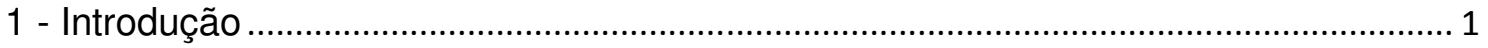

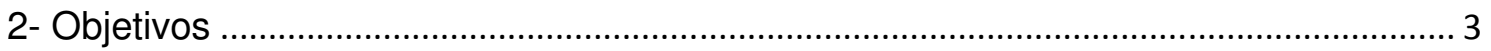

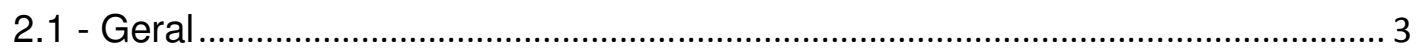

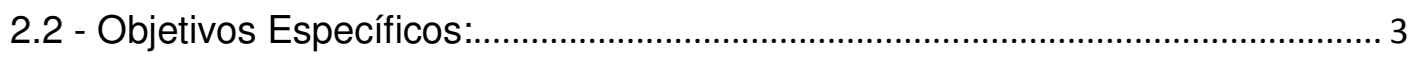

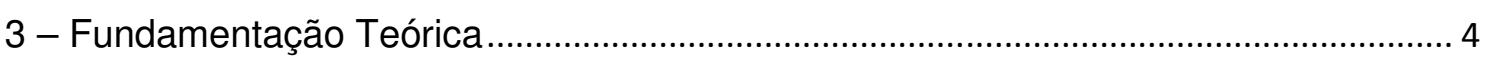

3.1 Sistemas Praiais - Conceitos e Processos .............................................................. 4

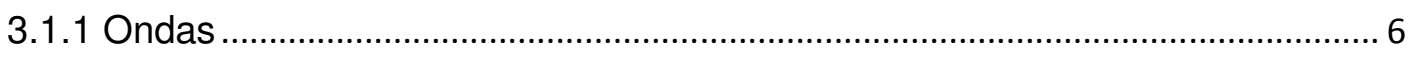

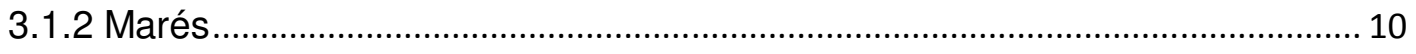

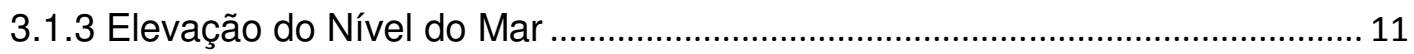

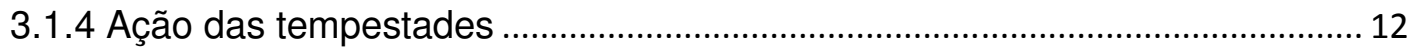

3.2 Estudos abordando a morfodinâmica dos sistemas praias..................................... 15

3.2.1 - Breve Histórico do Desenvolvimento dos Principais Métodos ....................... 15

3.2.2 - Estudos Enfocando a Morfodinâmica Praial na Costa do Brasil .................. 23

3.2.3 - Estudos Enfocando a Morfodinâmica Praial no Litoral Paulista ................... 24

3.2.4 - Estudos Utilizando o Sistema de Posicionamento Global Diferencial ........ 29

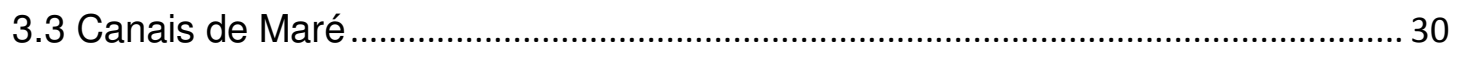

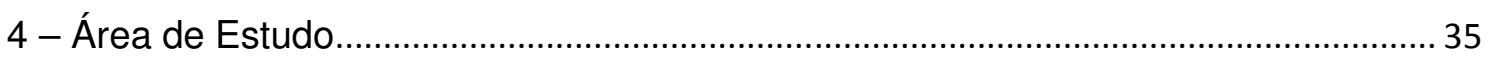

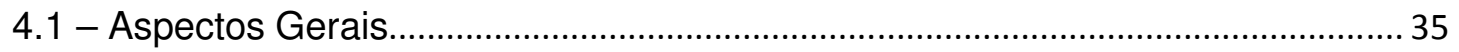

4.2 - Geologia e Geomorfologia da Planície Cananéia-Iguape...................................... 37

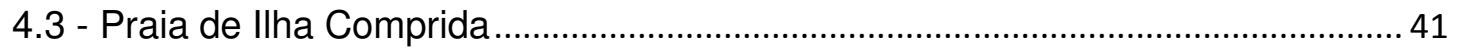

4.4 - Desembocadura de Cananéia .............................................................................. 43

4.5 - Fatores Oceanográficos e Meteorológicos............................................................ 51

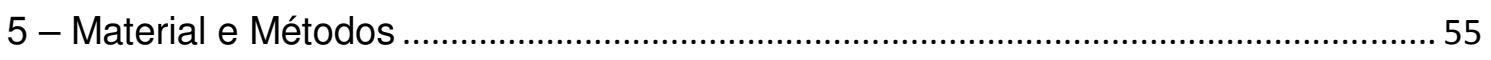

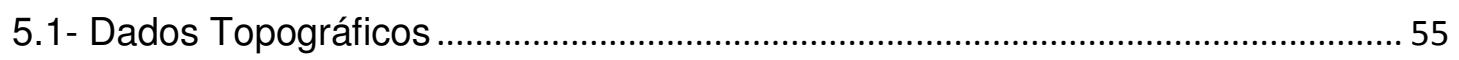

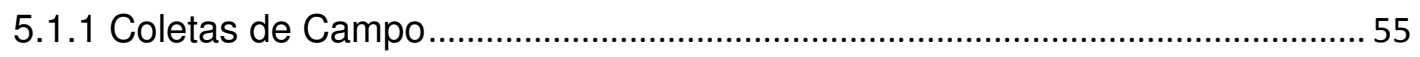

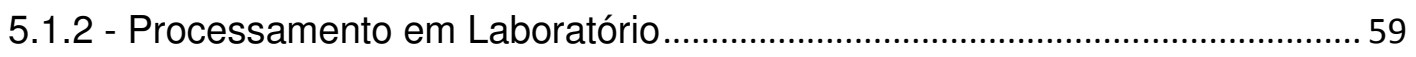

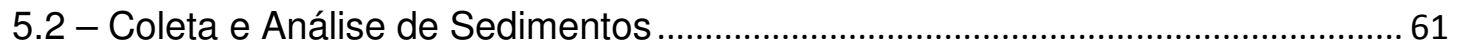

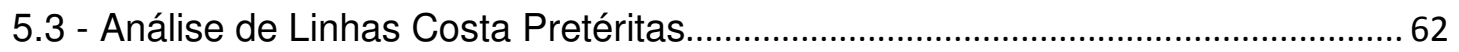

5.4 - Aquisição dos dados Oceanográficos e Meteorológicos ..................................... 64

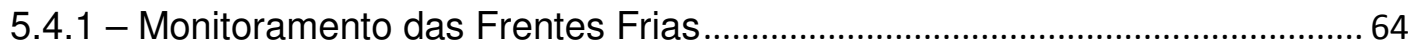




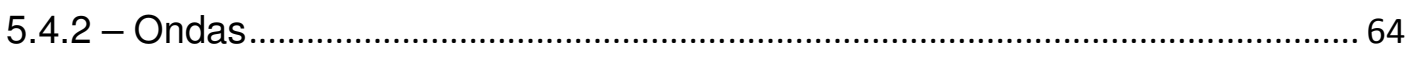

5.4.3 - Precipitação, Vento, Pressão e Maré.................................................................. 66

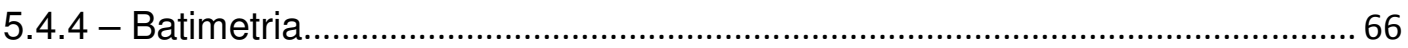

5.5 - Utilização do Sistema de Modelagem Costeira (SMC) …………….....................6 66

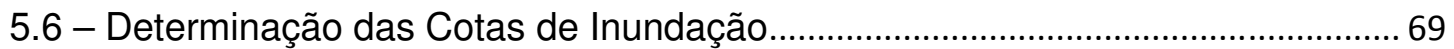

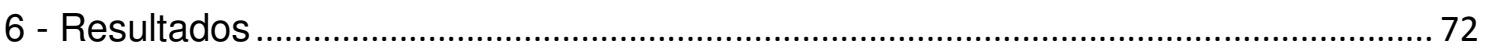

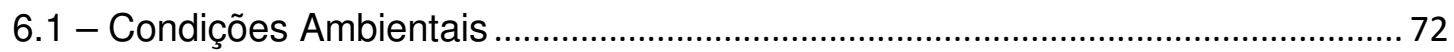

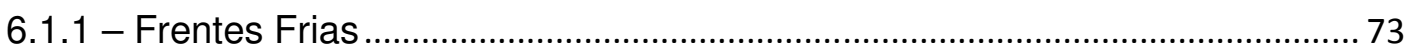

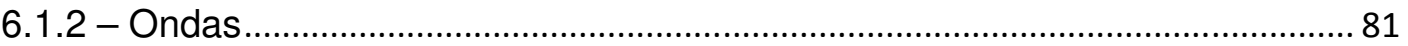

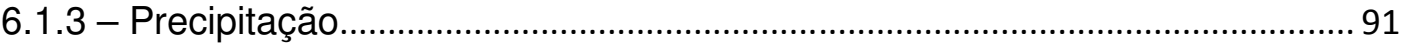

6.2 - Análises das Linhas de Costa Pretéritas .............................................................. 98

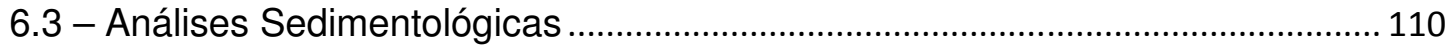

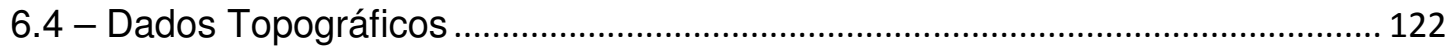

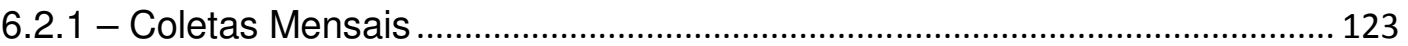

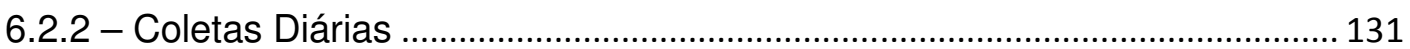

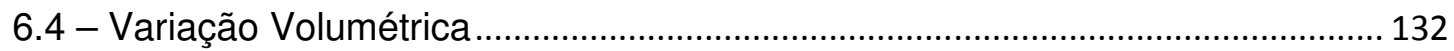

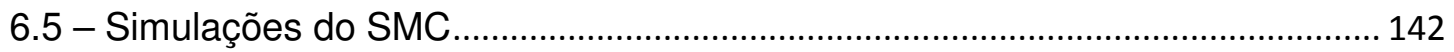

6.6 - Determinação das Cotas de Inundação..................................................................... 146

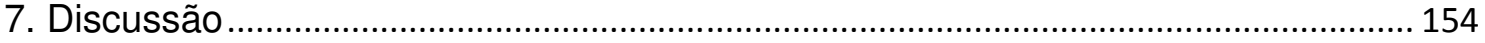

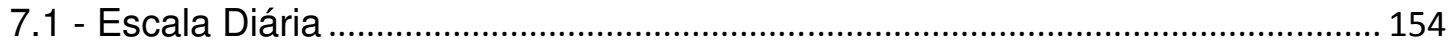

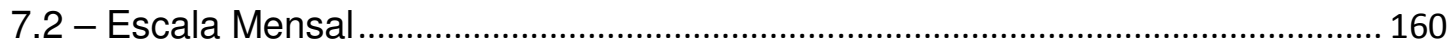

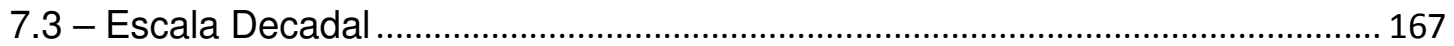

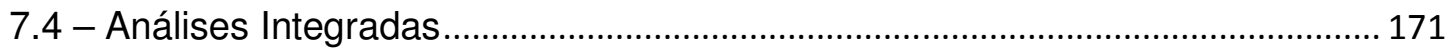

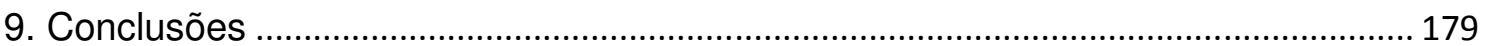

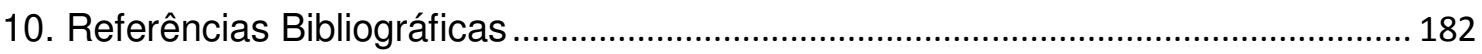

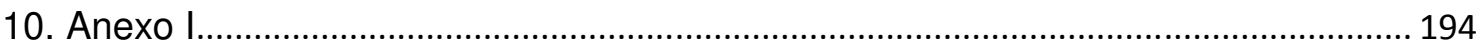

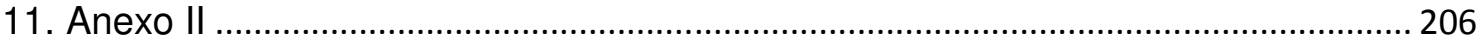




\section{Índice de figuras}

Figura 1: Terminologia de ambientes e subambientes litorâneos (Angulo, 1996)....................... 5

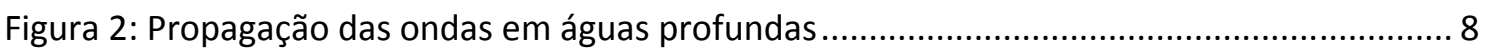

Figura 3: Propagação das ondas em águas rasas ................................................................... 8

Figura 4: Interação entre as correntes de deriva litorânea, ocorrendo no sentido longitudinal a linha de costa, e correntes onshore-offshore, atuando perpendicularmente a face praial.

(Adaptado de Short, 1999)

Figura 5: Série temporal da variação do volume da porção subaérea da praia de Moruya, no SE da Austrália, a partir de medições de campo. Notar a recuperação praial após a incidência de tempestades muito severas durante 1974. Adaptado de Short (1999).

Figura 6: Características dos diversos estados praias para condições de ondas construtiva (lado esquerdo) e erosivas (lado direito). Extraído de Calliari et al., 2003.

Figura 7: Estabilidade dos estados praias, sua direção e taxa de mudanças em função de $\Omega$.

Extraído de Calliari et al., 2003.

Figura 8: Principais componentes de uma desembocadura, (modificado de Boothroyd 1985;

CERC 2002).

Figura 9: Diagrama esquemático das correntes de maré enchente e vazante na porção marinha

do canal. (Modificado de O'Brien, 1969; CERC, 2002).

Figura 10: A morfologia de um delta de maré vazante indicando a influência relativa de ondas versus energia da maré bem como a direção dominante do transporte de sedimento paralelo à

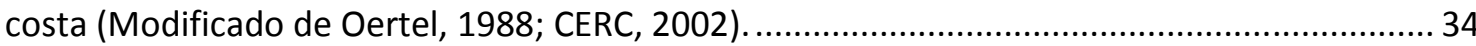

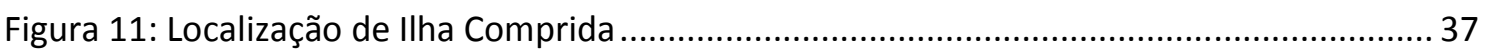

Figura 12: Escala de cor representando os domínios dos fluxos de maré sobre o fundo inferido a partir da morfologia das feições (setas brancas) e estimado por Tessler \& Souza (1998) (setas escuras). Extraído de Paolo \& Mahiques (2008)

Figura 13: Resultante do transporte, onde cada vetor representa a direção e o sentido preferencial da circulação de fundo em cima de cada feição identificada. Escala de cor representando qualitativamente a intensidade relativa deste transporte, onde as feições simétricas representam transporte mínimo. Extraído de Paolo \& Mahiques (2008)................. 49

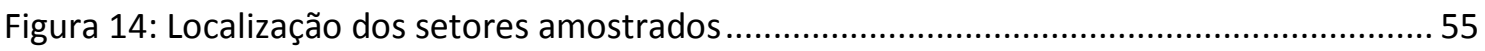

Figura 15: Áreas Leste e Sul do Setor 2 e o percurso do levantamento realizado no dia

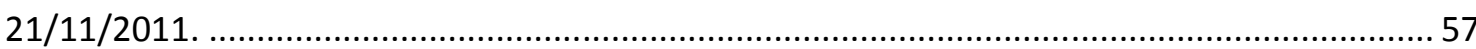

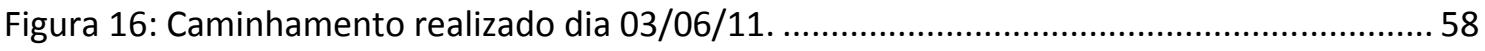

Figura 17: Caminhamento no limite entre face praial e vegetação........................................... 59

Figura 18: Posição dos pontos de amostragens de sedimento. A: Setor 2; B: Setor 1. ...............61 61

Figura 19: Módulos do Sistema de Modelado Costeiro (SMC) com respectivos dados de entrada e saída.

Figura 20: Ocorrências de frentes frias no mês de maio de 2011 no litoral brasileiro. Extraído da Síntese Sinótica Mensal do CPTEC.

Figura 21: Ocorrências de frentes frias no mês de junho de 2011 no litoral brasileiro. Extraído

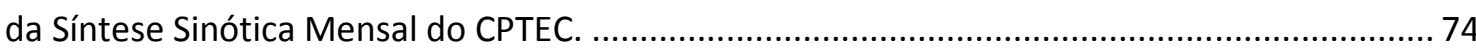
Figura 22: Ocorrências de frentes frias no mês de julho de 2011 no litoral brasileiro. Extraído da Síntese Sinótica Mensal do CPTEC. 
Figura 23: Ocorrências de frentes frias no mês de agosto de 2011 no litoral brasileiro. Extraído da Síntese Sinótica Mensal do CPTEC.

Figura 24: Ocorrências de frentes frias no mês de setembro de 2011 no litoral brasileiro.

Extraído da Síntese Sinótica Mensal do CPTEC.

Figura 25: Ocorrências de frentes frias no mês de outubro de 2011 no litoral brasileiro.

Extraído da Síntese Sinótica Mensal do CPTEC.

Figura 26: Ocorrências de frentes frias no mês de novembro de 2011 no litoral brasileiro.

Extraído da Síntese Sinótica Mensal do CPTEC.

Figura 27: Ocorrências de frentes frias no mês de dezembro de 2011 no litoral brasileiro.

Extraído da Síntese Sinótica Mensal do CPTEC.

Figura 28: Ocorrências de frentes frias no mês de janeiro de 2012 no litoral brasileiro. Extraído

da Síntese Sinótica Mensal do CPTEC.

Figura 29: Ocorrências de frentes frias no mês de fevereiro de 2012 no litoral brasileiro.

Extraído da Síntese Sinótica Mensal do CPTEC.

Figura 30: Rosas de Ondas para 05/2011. Gráfico da direita referente à altura de ondas por direção de propagação e gráfico da esquerda referente a período de ondas por direção de propagação, resultados em metros e segundos respectivamente.

Figura 31: Rosas de Ondas para 06/2011. Gráfico da direita referente a altura de ondas por direção de propagação e gráfico da esquerda referente a período de ondas por direção de propagação, resultados em metros e segundos respectivamente.

Figura 32: Rosas de Ondas para 07/2011. Gráfico da direita referente à altura de ondas por direção de propagação e gráfico da esquerda referente a período de ondas por direção de propagação, resultados em metros e segundos respectivamente.

Figura 33: Rosas de Ondas para 08/2011. Gráfico da direita referente à altura de ondas por direção de propagação e gráfico da esquerda referente a período de ondas por direção de propagação, resultados em metros e segundos respectivamente.

Figura 34: Rosas de Ondas para 09/2011. Gráfico da direita referente à altura de ondas por direção de propagação e gráfico da esquerda referente a período de ondas por direção de propagação, resultados em metros e segundos respectivamente.

Figura 35: Rosas de Ondas para 10/2011. Gráfico da direita referente à altura de ondas por direção de propagação e gráfico da esquerda referente a período de ondas por direção de propagação, resultados em metros e segundos respectivamente.

Figura 36: Rosas de Ondas para 11/2011. Gráfico da direita referente à altura de ondas por direção de propagação e gráfico da esquerda referente a período de ondas por direção de propagação, resultados em metros e segundos respectivamente.

Figura 37: Rosas de Ondas para 12/2011. Gráfico da direita referente à altura de ondas por direção de propagação e gráfico da esquerda referente a período de ondas por direção de propagação, resultados em metros e segundos respectivamente.

Figura 38: Rosas de Ondas para 01/2012. Gráfico da direita referente à altura de ondas por direção de propagação e gráfico da esquerda referente a período de ondas por direção de propagação, resultados em metros e segundos respectivamente.

Figura 39: Rosas de Ondas para 02/2012. Gráfico da direita referente à altura de ondas por direção de propagação e gráfico da esquerda referente a período de ondas por direção de propagação, resultados em metros e segundos respectivamente. 
Figura 40: Rosas de Ondas para o período total analisado, ou seja, entre 05/2011 e 02/2012. Gráfico da direita referente à altura de ondas por direção de propagação e gráfico da esquerda referente a período de ondas por direção de propagação, resultados em metros e segundos respectivamente.

Figura 41: Precipitação acumulada mensal no período entre 05/2011 e 05/2012. Valores em $\mathrm{mm}$.

Figura 42: Precipitação diária no período entre 02/06/2011 e 26/07/2011. Valores em mm... 93 Figura 43: Precipitação diária no período entre 26/07/2011 e 12/08/2011. Valores em mm... 94 Figura 44: Precipitação diária no período entre 12/08/2011 e 30/09/2011. Valores em mm... 94 Figura 45: Precipitação diária no período entre 30/09/2011 e 25/11/2011. Valores em mm... 95 Figura 46: Precipitação diária no período entre 25/11/2011 e 15/12/2011. Valores em mm... 96 Figura 47: Precipitação diária no período entre 15/12/2011 e 30/01/2012. Valores em mm... 97 Figura 48: Precipitação diária no período entre 30/01/2012 e 27/02/2012. Valores em mm... 98 Figura 49: Linhas de costa obtidas a partir das fotografias aéreas e imagens de satélite sobrepostas a fotografia aérea de 2001.

Figura 50: Transectos gerados para o calculo da TVLc e linhas de costa de 1981 (linha azul pontilhada) e 2001 (linha cheia preta).

Figura 51: Setores adotados para facilitar a exposição dos resultados. Setor 1 - Vermelho, Setor 2 - Azul; Setor 3 - Verde.

Figura 52: Resultados do cálculo da TVLc entre os anos de 1962 e 1973, valores em m/ano. 103 Figura 53: Resultados do cálculo de TVLc para período entre 1973 e 1981, valores expressos em $\mathrm{m} / \mathrm{ano}$ 104

Figura 54: Resultados do cálculo de TVLc para período entre 1981 e 2001, valores expressos em $m$ /ano. 105

Figura 55: Resultados do cálculo de TVLc para período entre 2001e 2009, valores expressos em $\mathrm{m} / \mathrm{ano}$. 106

Figura 56: Resultados do cálculo de TVLc para período entre 1962 e 2009, valores expressos em $\mathrm{m} / \mathrm{ano}$ 108

Figura 57: Linhas de costas obtidas para os anos de 1973 e 1981 sobrepostas a fotografia de 1973. Notar a presença do rio e tênue presença da linha de vegetação.

Figura 58: Resultados obtidos para variação dos parâmetros sedimentares no ponto P1S1. Barra Azul - Diâmetro Médio; Barra Roxa - Desvio Padrão; Barra Vermelha - Assimetria; Barra Verde - Curtose

Figura 59: Resultados obtidos para variação dos parâmetros sedimentares no ponto P2S1. Barra Azul - Diâmetro Médio; Barra Roxa - Desvio Padrão; Barra Vermelha - Assimetria; Barra Verde - Curtose.

Figura 60: Resultados obtidos para variação dos parâmetros sedimentares no ponto P3S1. Barra Azul - Diâmetro Médio; Barra Roxa - Desvio Padrão; Barra Vermelha - Assimetria; Barra Verde - Curtose.

Figura 61: Resultados obtidos para variação dos parâmetros sedimentares no ponto P4S1. Barra Azul - Diâmetro Médio; Barra Roxa - Desvio Padrão; Barra Vermelha - Assimetria; Barra Verde - Curtose. 112

Figura 62: Resultados obtidos para variação dos parâmetros sedimentares no ponto P1S2. Barra Azul - Diâmetro Médio; Barra Roxa - Desvio Padrão; Barra Vermelha - Assimetria; Barra Verde - Curtose. 
Figura 63: Resultados obtidos para variação dos parâmetros sedimentares no ponto P2S2. Barra Azul - Diâmetro Médio; Barra Roxa - Desvio Padrão; Barra Vermelha - Assimetria; Barra Verde - Curtose.

Figura 64: Resultados obtidos para variação dos parâmetros sedimentares no ponto P3S2. Barra Azul - Diâmetro Médio; Barra Roxa - Desvio Padrão; Barra Vermelha - Assimetria; Barra Verde - Curtose.

Figura 65: Resultados obtidos para variação dos parâmetros sedimentares no ponto P4S2. Barra Azul - Diâmetro Médio; Barra Roxa - Desvio Padrão; Barra Vermelha - Assimetria; Barra Verde - Curtose.

Figura 66: Resultados obtidos para variação dos parâmetros sedimentares no ponto P5S2. Barra Azul - Diâmetro Médio; Barra Roxa - Desvio Padrão; Barra Vermelha - Assimetria; Barra Verde - Curtose.

Figura 67: Resultados obtidos para variação dos parâmetros sedimentares no ponto P6S2. Barra Azul - Diâmetro Médio; Barra Roxa - Desvio Padrão; Barra Vermelha - Assimetria; Barra Verde - Curtose.

Figura 68: Resultados obtidos para variação dos parâmetros sedimentares no ponto P7S2. Barra Azul - Diâmetro Médio; Barra Roxa - Desvio Padrão; Barra Vermelha - Assimetria; Barra Verde - Curtose.

Figura 69: Resultados obtidos para variação dos parâmetros sedimentares no ponto P8S2.

Barra Azul - Diâmetro Médio; Barra Roxa - Desvio Padrão; Barra Vermelha - Assimetria; Barra Verde - Curtose.

Figura 70: Resultados obtidos para variação dos parâmetros sedimentares no ponto P9S2.

Barra Azul - Diâmetro Médio; Barra Roxa - Desvio Padrão; Barra Vermelha - Assimetria; Barra Verde - Curtose.

Figura 71: Resultados obtidos para variação dos parâmetros sedimentares no ponto P10S2.

Barra Azul - Diâmetro Médio; Barra Roxa - Desvio Padrão; Barra Vermelha - Assimetria; Barra Verde - Curtose.

Figura 72: Resultados obtidos para variação dos parâmetros sedimentares no ponto P11S2.

Barra Azul - Diâmetro Médio; Barra Roxa - Desvio Padrão; Barra Vermelha - Assimetria; Barra Verde - Curtose

Figura 73: Resultados obtidos para variação dos parâmetros sedimentares no ponto P12S2. Barra Azul - Diâmetro Médio; Barra Roxa - Desvio Padrão; Barra Vermelha - Assimetria; Barra Verde - Curtose

Figura 74: MDT gerado a partir dos dados do levantamento do dia 23/11/2011.

Figura 75: Detalhe dos dados coletados nos caminhamentos dos 03/06/2011(vermelho) e 06/06/2011(preto). Notar a maior abrangência do levantamento do dia 06/06 no limite superior da figura.

Figura 76: Variação líquida do volume na Área Leste do Setor 2 durante todo o período de levantamento.

Figura 77: Variação total do volume na Área Leste do Setor 2 durante todo o período de levantamento.

Figura 78: Variação mensal líquida de volume na Área Leste do Setor 2, valores em $\mathrm{m}^{3}$........ 135

Figura 79: Variação mensal total de volume na Área Leste do Setor 2, valores em m ${ }^{3}$............ 136

Figura 80: Variação líquida do volume na Área Sul do Setor 2 durante todo o período de levantamento. 
Figura 81: Variação total do volume na Área Sul do Setor 2 durante todo o período de levantamento.

Figura 82: Variação mensal líquida de volume na Área Sul do Setor 2, valores em $\mathrm{m}^{3}$............. 139

Figura 83: Variação mensal total de volume na Área Sul do Setor 2, valores em $\mathrm{m}^{3}$................ 139

Figura 84: Variação líquida diária do volume do Setor 1, valores em $\mathrm{m}^{3}$................................. 141

Figura 85: Variação diária líquida de volume do Setor 2, valores em $\mathrm{m}^{3}$. ................................ 141

Figura 86: Área de influência da Desembocadura de Cananéia delimitada pela linha vermelha pontilhada. Notar os bancos areia dispostos entorno da saída da desembocadura.

Figura 87: Dados utilizados na cofecção do MDT. Pontos Pretos - dados coletados em campo; Pontos Vermelhos - dados do modelo digital de elevação global do software Goggle Earth ${ }^{\circledR}$.

Figura 88: Elevação do mar de 1,4 m sobreposto ao MDT (Caso 1) ....................................... 148

Figura 89: Elevação do mar de 2.02 m sobreposto ao MDT (Caso 2) ........................................ 149

Figura 90: Elevação do mar de 2.47 m sobreposto ao MDT (Caso 3). ....................................... 150

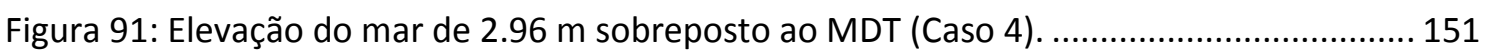

Figura 92: Elevação do mar de 1.27 m sobreposto ao MDT (Caso 5) ........................................ 152

Figura 93: Elevação do mar de 1.52 m sobreposto ao MDT (Caso 6) ...................................... 153

Figura 94: Previsão da posição da linha de costa em 50 anos no futuro baseada nos resultados

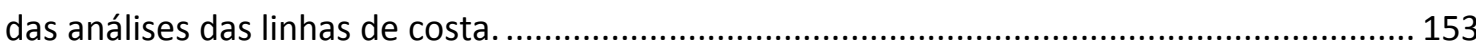

Figura 95: Alturas das ondas registradas entre os dias 03/06/2011 e 06/06/2011, observações

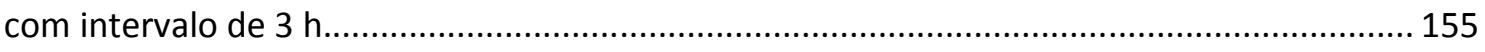

Figura 96: Períodos das ondas registrados entre os dias 03/06/2011 e 06/06/2011, observações

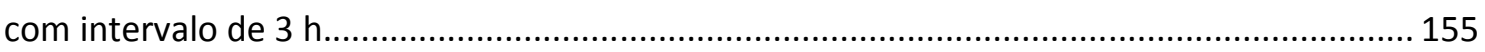

Figura 97: Direções das ondas registradas entre os dias 03/06/2011 e 06/06/2011, observações

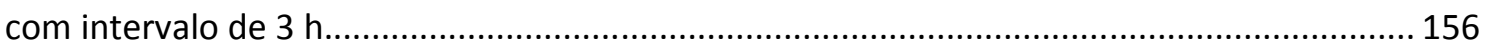

Figura 98: Maré meteorológica observada no dia 04/06, notar a água invadindo a estrada de

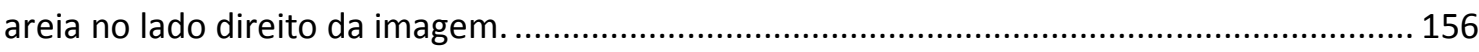

Figura 99: Maré meteorológica observa no dia 04/06, notar a ação das ondas na escarpa que

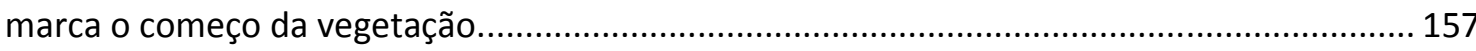

Figura 100: Ação dos ventos transportando sedimentos no dia 04/06, ilhas do Cardoso e do

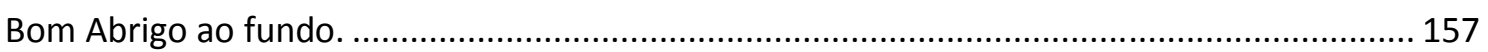

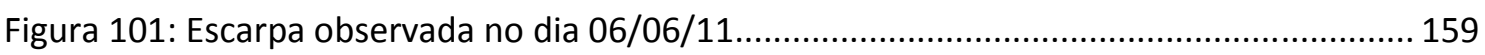

Figura 102: Escarpa secundaria localizada abaixo da escarpa que divide a faixa de areia e

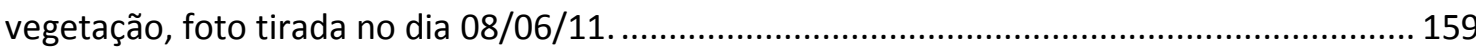

Figura 103: Escarpa produzida pela passagem de uma frente fria no mês de maio de 2011.

Segundo os comerciantes locais varias dessas estruturas foram derrubadas.......................... 160

Figura 104: Altura das ondulações registradas durante o período entre 06/2011 e 02/2012. 162

Figura 105: Direções das ondulações registradas durante o período entre 06/2011 e 02/2012.

Figura 106: Períodos das ondulações registradas durante o período entre 06/2011 e 02/2012.

Figura 107: Poças de água acumuladas na face praial e zona de arrebentação no mês de

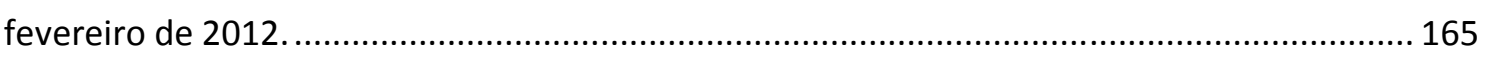

Figura 108: Acumulações pronunciadas de água na faixa de areia no ano de 2001. ................ 165 
Figura 109: Comparação entre os caminhamentos dos dias 03/06/2011 e 24/02/2012

denotando a retração da linha de vegetação. Imagem de satélite de 2009 ao fundo.

Figura 110: Posição dos deltas de vazante saída da Desembocadura de Cananéia.

Figura 111: Comparação entre as Linhas de Costa de 2001, 2009 e fevereiro de 2012. Imagem de satélite de 2009 ao fundo.

Figura 112: Sobreposição das Linhas de Costa de 2001 e 2009 ao MDT referente a comparação entre o primeiro e o último levantamento topográfico. Imagem de satélite de 2009 ao fundo.

\section{Índice de tabelas}

Tabela 1: Direções adotadas e seus respectivos intervalos.

Tabela 2: Comparação entre os dias de ocorrência de frentes frias e os dias de saídas a campo.

A coluna da esquerda corresponde ao acontecimento das coletas e a segunda coluna a ocorrência de sistemas frontais.

Tabela 3: Valores de RMS utilizados na aplicação da extensão DSAS.

Tabela 4: Valores máximos e mínimos da variação da linha costa nos períodos analisados. A coluna da esquerda representa a variação em metros por ano (TVLc m/ano), e a coluna da direita representa a variação total em metros (TVLc tot).

Tabela 5: Resultados dos volumes para todos os levantamentos executados na Área Leste do Setor 2. Da esquerda para direita, Tabela A: Volumes líquidos; Tabela B: Volumes totais...... 135 Tabela 6: Variação mensal dos volumes durante os levantamentos executados na Área Leste do Setor 2. Da esquerda para direita, Tabela A: Volumes líquidos; Tabela B: Volumes totais. 136 Tabela 7: Resultados dos volumes para todos os levantamentos executados na Área Sul do Setor 2. Da esquerda para direita, Tabela A: Volumes líquidos; Tabela B: Volumes totais...... 138 Tabela 8: Variação mensal dos volumes durante os levantamentos executados na Área Sul do Setor 2. Da esquerda para direita, Tabela X: Volumes líquidos; Tabela Y: Volumes totais. ..... 140 Tabela 9: (da esquerda para direita) Tabela A: Variação diária dos volumes do Setor 1, Tabela B: Variação mensal dos volumes do Setor 1 , valores em $\mathrm{m}^{3}$. 142 Tabela 10: Resumo dos casos selecionados e seus respectivos parâmetros. Valores de direção em graus, altura de onda $(\mathrm{H})$ em metros, períodos de ondas $(\mathrm{T})$ em segundos e profundidade inicial da onda (Prof) em metros

Tabela 11: Valores utilizados para obtenção das cotas de inundação. Valores de maré corrigidos para o datum do IBGE. Valores em metros. 


\section{Agradecimentos}

Esta, como a maioria das dissertações de mestrado, é fruto do trabalho de muitas pessoas. Vou me esforçar muito para lembrar de todo mundo, mas agente sempre esquece alguém.

Em primeiro lugar agradeço ao meu orientador Prof. Moysés Gonsalez Tessler pela oportunidade oferecida, pelo bom humor, pelas orientações fundamentais e a sabedoria compartilhada. Agradeço ao Prof. Eduardo Siegle pelos empréstimos de equipamento, laboratório e orientações, sem ele não haveria dissertação.

Agradeço ao amigo Mario Luiz Mascagni pela grandessíssima ajuda prestada em todos os aspectos, acadêmicos, pessoais e profissionais. Pode se dizer que ele é o "culpado" pela dissertação.

Agradeço a CAPES pelo financiamento, e pela oportunidade de integrar a "Rede Interdisciplinar para a Análise de Riscos Costeiros a Eventos Atmosféricos Extremos devido as Mudanças Globais nas regiões Sul e Sudeste do Brasil [REDE RISCOSCOSTEIROS]", Edital Ciências do Mar - CAPES - N 09/2009.

Agradeço aos técnicos da Geo do IO, Marcelo Rodrigues, Samara Cazzoli y Goya e Edilson Oliveira pela grande ajuda prestada, nas análises sedimentares, no SURFER, e por fim na escrita. Agradeço em especial a Samara pela calma, atenção e correria.

Agradeço muito a todos que me ajudaram nos campos, Manapé, Carlos, Dani, Ferru, Nery, Juzinha. Em muito especial a Janaina Moslavacz Camargo. Valeu Jana, sem você não ia ter campo.

Agradeço ao pessoal da Base de Cananéia e da Administração do 
IOUSP pela ajuda nas questões práticas e burocráticas.

Agradeço aos orientados do Prof. Moysés; Dani, Carlos e Janaína; e o pessoal do LDC; PH, Pitu, Escadinha, Mirella, Juzinha, Diana (essa é agregada, mas conta também) pelo convívio e trocas de ideias.

Agradeço muito aos amigos do 10 nesses quase 10 anos de USP, Oceanografia não é pra qualquer um!

Agradeço aos irmãos e moradores dos Orcas, republica já famigerada, pelas risadas, cervejas, churrascos, baladas e o acima de tudo 0 companheirismo. Valeu Derico, Rosinha e Uiu!

Agradeço muito, mas muito mesmo a Paula Carneiro Romagnoli, melhor namorada do mundo, melhor companhia do mundo e a arquiteta que mais entende de sedimentação costeira do mundo. Muito obrigado por estar do meu lado e ser compreensiva meu amor.

Por último, mas não menos importante a todos meus familiares que mal entendem o que eu faço, mas mesmo assim me apoiam. Meus primos e tias pela infância maravilhosa e pelos cuidados. A meu irmão por todo o trabalho e amor dado.

Em muito especial meus pais, José Wilson Gagliardi e Maria Cristina Chagas Gagliardi pela educação, formação e todo amor. Nunca vou conseguir agradecê-los o suficiente.

A minhas avós, Dona Haydé e Dona Margot, por toda a preocupação e amor.

A meus avôs, Seu Nino e Seu Loca, por todo carinho e dedicação. 


\section{Resumo}

O atual estudo visa cooperar na compreensão dos efeitos da passagem de tempestades extremas sobre os sistemas litorâneos através do estudo de caso na Desembocadura de Cananéia, localizada na llha Comprida SP. O trabalho contou com campanhas de campo para levantamento de dados topográficos e coletas de sedimentos, análises das condições ambientais atuantes durante o período dos campos, determinação da evolução da linha de costa através da análise de fotos aéreas e imagens de satélite e simulações numéricas para caracterizar o regime de ondas atuante na região. Foram produzidos mapas temáticos para representar as cotas de inundação associadas a ocorrência de marés meteorológicas .Os resultados indicaram que a ação das ondas de tempestade se da principalmente por meio do transporte onshore-offshore nas escalas temporais diária e mensal. A evolução da linha de costa obtida apontou para maior eficiência das correntes de deriva litorânea na escala decadal. A comparação entre os resultados topográficos/volumétricos e da evolução da linha de costa evidenciam uma tendência erosiva nas adjacências do Pontal de Fora associada à incidência de eventos atmosféricos extremos para o período entre 2001 e início de 2012. Os resultados das determinações das cotas de inundação apontam que os maiores impactos locais associados às mudanças climáticas serão provenientes das alterações na frequência de ocorrência e intensidade das tempestades.

Palavras Chaves: Morfodinâmica Costeira, eventos extremos, marés meteorológicas, mudanças climáticas. 


\section{Abstract}

The current study aims to cooperate in the knowledge about the effects of the occurrence of extreme storms on coastal systems through the case study of the Desembocadura de Cananéia, located on Ilha Comprida - SP. The work included campaigns of field survey to collect topographic data and sediment samples, analysis of environmental conditions during the period of surveys, determination of the shoreline evolution through analysis of aerial photos and satellite images and numerical simulations to characterize the wave regime present in the region. Thematic maps were produced to represent the flood hazard associated with the occurrence of storm surges. Results indicated that the action of storm waves occurs primarily by means of the onshore-offshore transport on daily and monthly time scales. The evolution of the shoreline obtained pointed to greater efficiency of longshore currents on the decadal scale. The comparison between the topographic/volumetric results and the evolution of the coastline shows an erosive trend in the vicinity of the Pontal de Fora associated with the incidence of extreme weather events for the period between 2001 and early 2012. The results of the determinations of flood hazard areas points out that the major local impacts related to the global climate changes will come from variations in the frequency of occurrence and intensity of storms.

Key words: Coastal Morphodynamics, extreme events, storm surge, climate change. 


\section{1 - Introdução}

Desde o principio de sua história a raça humana tenta entender os processos naturais e suas consequências, sendo esta sua mais valiosa ferramenta para resistir e se adaptar às mudanças do planeta. Apesar do relativo sucesso em identificar as diferentes forçantes físicas presentes na natureza, suas combinações causam efeitos muitas vezes sutis, que revelam sua real importância somente em escalas de tempo que excedem em muito a própria escala de tempo humana.

Com o aumento exponencial da população e o desenvolvimento cada vez maior da ciência e da tecnologia, o homem começou a tentar entender o seu papel modificador nos ambientes em que vive, classificando sua influência na forma de processos antrópicos. Nas duas últimas décadas surgiram indícios de que tais processos sejam responsáveis por um aumento anômalo nas temperaturas atmosféricas em todo o globo (IPCC, 2007). Apesar de controvérsias ainda existirem acerca da importância relativa entre causas antrópicas e naturais nos processos controladores das alterações climáticas e da intensidade destas, suas consequências são reais e devem ser levadas em conta no planejamento urbano e econômico a médio e longo prazo.

Os ambientes costeiros estão entre as áreas do globo mais afetadas por essas mudanças devido a sua grande complexidade. O caráter transicional desses ambientes faz com que os processos atuantes sejam notadamente complexos, havendo interação entre os meios terrestres, marinhos e atmosféricos. Suas características são moldadas e moldam os processos atuantes e as escalas envolvidas variam espacialmente desde poucos 
centímetros até milhares de quilômetros, e temporalmente desde poucas horas a milhões de anos (CERC, 2002).

Além da grande variedade natural, a faixa costeira é uma das áreas do globo mais ocupadas pelo homem. Segundo o Atlas of the Oceans publicado pelas Nações Unidas em 2002 (http://www.oceansatlas.org, acessado em 22/11/2012), 44\% da população mundial habita uma faixa de $150 \mathrm{~km}$ a partir do nível do mar, além de 8 das 10 maiores megalópoles do mundo estarem localizadas na mesma faixa. Os impactos decorrentes da presença do homem são variados e podem acarretar modificações profundas da dinâmica dos processos físicos e biológicos presentes na zona costeira.

Os processos sedimentares em especial requerem uma grande atenção na construção de obras próximas a linha de costa ou curso de rios, entre outros, pois há o risco de perdas de terreno e prejuízos às atividades de navegação. As construções muitas vezes alteram o delicado balanço natural entre aporte e distribuição de sedimentos, agravando ou até mesmo causando situações de erosão costeira (Farinacceo, 2008).

Nestes termos pode-se afirmar que a ocupação e exploração da zona litorânea pelo homem impõem a compreensão de como estas interagem e afetam os processos naturais vigentes. No presente momento as alterações climáticas globais podem causar impactos até mesmo em áreas pouco habitadas, evidenciando a necessidade de se entender sua influência em ambientes variados. Dentre as consequências ambientais previstas, pode se citar a aceleração da elevação do nível relativo do mar (NRM) e as alterações nos ciclos de tempestades como os causadores mais prováveis de impactos na zona costeira, modificando os balanços sedimentares estabelecidos atualmente 
ao redor do globo (Muehe, 2001).

O presente trabalho busca contribuir com o conhecimento dos efeitos das atuais mudanças climáticas na dinâmica local dos diferentes sistemas costeiros. Pretende-se avaliar a influência destas mudanças em um ambiente pouco impactado pela ação humana, composto por uma feição praial e uma desembocadura estuarina/lagunar, localizada em Ilha Comprida - SP. Desta forma, acredita-se somar conhecimentos acerca da sedimentação atual do ambiente em questão e também ao processo de gestão costeira aplicado no Estado de São Paulo.

\section{2- Objetivos}

\section{1 - Geral}

O objetivo principal do estudo é contribuir com a compreensão dos efeitos das atuais mudanças climáticas na evolução geomorfológica dos ambientes costeiros atuais. Para tanto será realizado um estudo de caso em um setor localizado no sul de Ilha Comprida - SP, contando com levantamentos de dados topográficos em campo, análise da evolução da linha de costa, determinação das cotas de inundação e simulações numéricas.

\section{2 - Objetivos Específicos:}

- Identificar a influência da aceleração da elevação do nível relativo do mar nos processos sedimentares locais.

- Identificar a influência da passagem de frentes frias nos processos sedimentares atuantes nas adjacências da Desembocadura de Cananéia. 
- Definir área inundada atualmente nas adjacências da Desembocadura de Cananéia durante a ocorrência de marés meteorológicas extremas.

\section{3 - Fundamentação Teórica}

\subsection{Sistemas Praiais - Conceitos e Processos}

Sistemas praiais ocorrem por todo o globo onde quer que existam sedimentos e espaço para acomodação disponíveis para a atuação dos trens de ondas. Existem muitas definições formais para descrição das praias, talvez a forma mais simples seja a utilizada por Short (1999):

"Praias são acumulações de sedimentos depositados por ondas entre a base modal das ondas e o limite do espraiamento, onde a base modal das ondas corresponde à profundidade máxima na qual as ondas transportam os sedimentos em direção à costa, e o limite do espraiamento corresponde ao limite subaéreo da ação das ondas e consequentemente do seu transporte de sedimentos".

Apesar desta definição não englobar todos os processos transportadores de sedimentos e de não definir as subambientes presentes nos sistemas praias, ela demonstra claramente a importância da presença de ondas para formação das praias.

Além dos processos associados a ação das ondas, a ação das marés, dos ventos, a presença de drenagens fluviais, características sedimentares, e o histórico geológico da região influenciam muito na formação e dinâmica dos sistemas praiais. Devido a essa gama de fatores a evolução de um sistema praial se torna um assunto complexo a ser estudado, requerendo abordagens em escalas espaço-temporais distintas. De forma simplificada pode se 
enxergar esses sistemas como produto de eventos temporalmente instantâneos de natureza estocástica que produzem sistemas com caraterísticas determinísticas em escalas temporais mais amplas (Short, 1999).

Para facilitar seu estudo, os sistemas praiais são divididos em subambientes de acordo com os processos atuantes. A terminologia de tais subambientes praiais varia muito, tanto nos trabalhos nacionais quanto internacionais. A fim de se contornar este problema decidiu-se utilizar a nomenclatura proposta por Angulo (1996), expressa na figura 1.

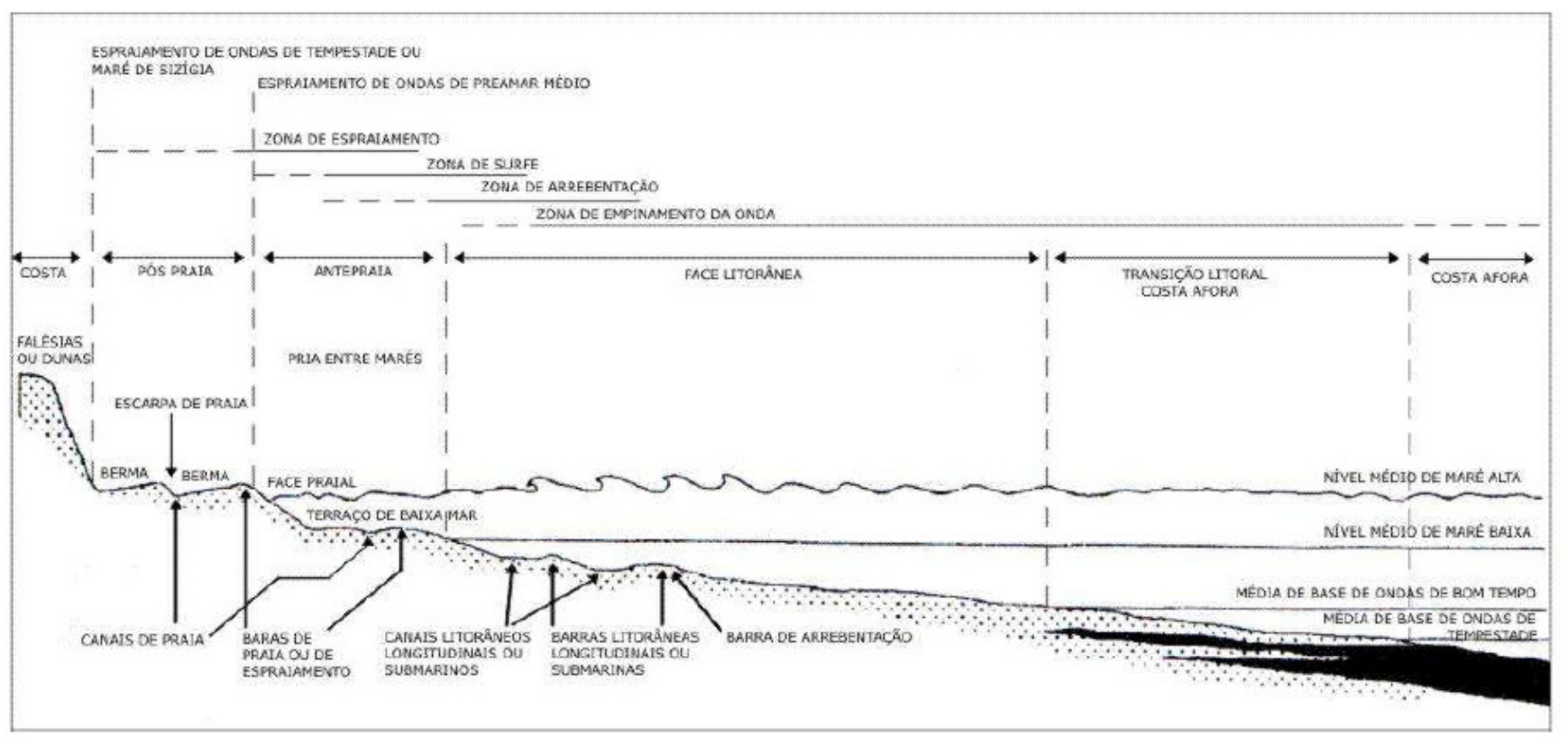

Figura 1: Terminologia de ambientes e subambientes litorâneos (Angulo, 1996).

Os limites entre a face litorânea, a costa afora e o início da zona de surf são controversos, pois são definidos pela ação dos trens de onda sobre o fundo marinho e a essa própria ação modifica essas feições em função da variação de energia nos diferentes trens de onda incidentes.

Hallermeir (1981) define o início da zona de surf como profundidade de fechamento interno, ou seja, o ponto onde as ondas quebram. O limite entre a 
face litorânea e a costa afora é definido como profundidade de fechamento externo pelo autor, ou seja, ponto onde a ação das ondas começa a remobilizar o sedimento de fundo. No estudo estão medições de perfis praiais, dados sobre os trens de onda incidentes e dados sobre as características sedimentares para estabelecer equações que calculam as profundidades em questão.

No caso da profundidade de fechamento interno os resultados alcançados se provaram validos apenas para "anos típicos" definidos pelo autor, ou seja, anos em que os perfis praiais não se alterem em mais de $0,3 \mathrm{~m}$ na escala vertical, sendo inadequado para períodos de tempo mais longos ou em que uma tempestade extrema atue sobre a costa. Já no caso da profundidade de fechamento externo a equação formulada acaba por não ser representativa, pois leva em consideração o diâmetro médio dos sedimentos submersos em seu calculo, parâmetro muito associado as condições ambientais locais.

Nas próximas seções serão tratados de forma mais detalhada os processos identificados como os mais importantes na formação e evolução dos sistemas praiais.

\subsubsection{Ondas}

A ação das ondas é a maior responsável pelas feições observadas nas praias. As ondas capazes de formar feições praiais normalmente são as chamadas ondas de gravidade, ou seja, ondas em que o mecanismo reparador do movimento é a força gravitacional. Sua formação está associada a troca de energia entre a atmosfera e o oceano por meio do atrito entre o vento e a superfície do mar.

As características das ondas, como altura e período, dependem das 
características de seu vento formador, tais como sua intensidade, tempo de duração e tamanho da pista, ou seja, a extensão da superfície aquosa sobre a qual o vento atua. Nas proximidades de sua zona de formação as ondulações recebem o nome de sea ou vaga e à medida que em se distanciam dessa zona são denominadas de swell ou marulho.

As ondas de gravidade, como qualquer outro tipo de onda, não transportam matéria, tratando-se de pulsos energéticos que se propagam através do espaço ou de um meio físico transferindo energia de um lugar para outro sem que qualquer das partículas do meio seja deslocada.

À medida que as ondas se afastam da sua área de formação ocorrem modificações em suas características básicas (altura e período). Outro processo marcante é o agrupamento de trens de onda com velocidades de propagação semelhantes e por consequência com períodos e alturas também semelhantes.

A propagação das ondas de gravidade no oceano faz com que as partículas de água descrevam movimentos orbitais circulares, cujos raios diminuem em direção ao fundo oceânico. Em águas profundas as orbitais se dissipam antes de tocar o fundo (figura 2), porém em águas mais rasas o atrito com o fundo deforma as orbitais, transformando-as em elipses nas proximidades da superfície que se tornam cada vez mais achatados com o aumento da profundidade, como pode ser observado na figura 3 . Esse processo gera um fluxo capaz de transportar os sedimentos do leito marinho. 


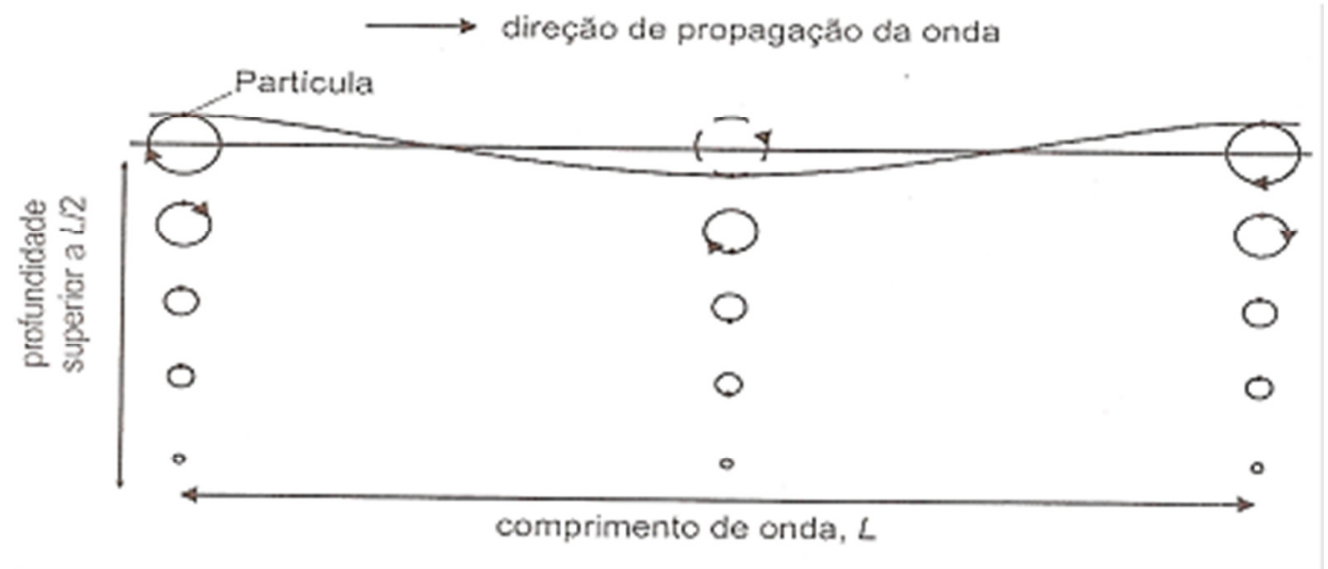

Figura 2: Propagação das ondas em águas profundas

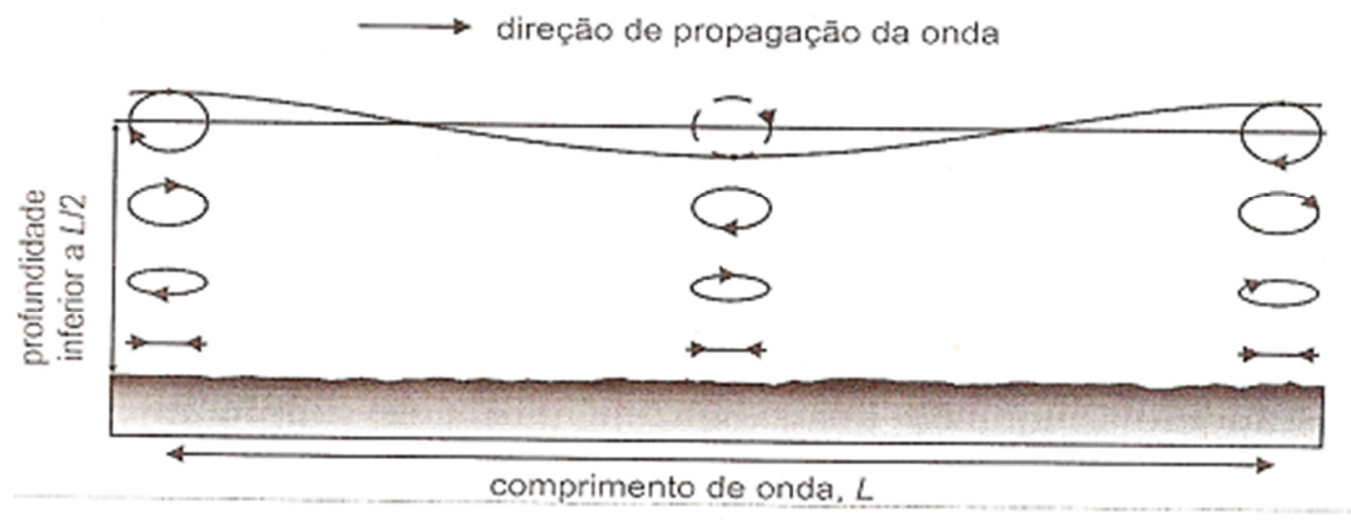

Figura 3: Propagação das ondas em águas rasas

O processo de transformação das orbitais das ondas em águas rasas é conhecido como wave shoaling. Os fluxos de água gerados por este processo são as correntes costeiras responsáveis pelo perfil côncavo clássico observado nos sistemas praiais, sendo estas conhecidas como correntes de deriva litorânea e as correntes costa afora - costa adentro (onshore-offshore).

A corrente de deriva litorânea é causada pela incidência dos trens de ondas se dar de forma obliqua a face praial, sempre transportando sedimento paralelamente à faixa de areia. A direção da corrente depende do ângulo com que os trens de onda atingem a praia e sua intensidade depende da altura e do 
período das ondas associados. As correntes onshore-offshore transportam sedimentos no sentido perpendicular à linha de costa e estão ligadas principalmente a intensidade das ondas atuantes na face praial.

Ambas as correntes são criadas na zona de surf e costumam atuar em conjunto no sistema praial, sendo responsáveis pelo balanço de sedimento entre a face subaérea e a face submersa das praias. Seus efeitos são visíveis na forma de feições morfológicas como escarpas de erosão e bancos de areias submersos. A ação conjunta das duas correntes normalmente gera células de circulação perpendiculares à costa com rotação de sedimentos. A figura 4 sintetiza a interação entre as duas correntes e a linha costa, havendo um equilíbrio dinâmico entre o ângulo e intensidade das ondas incidentes e as feições morfológicas resultantes.

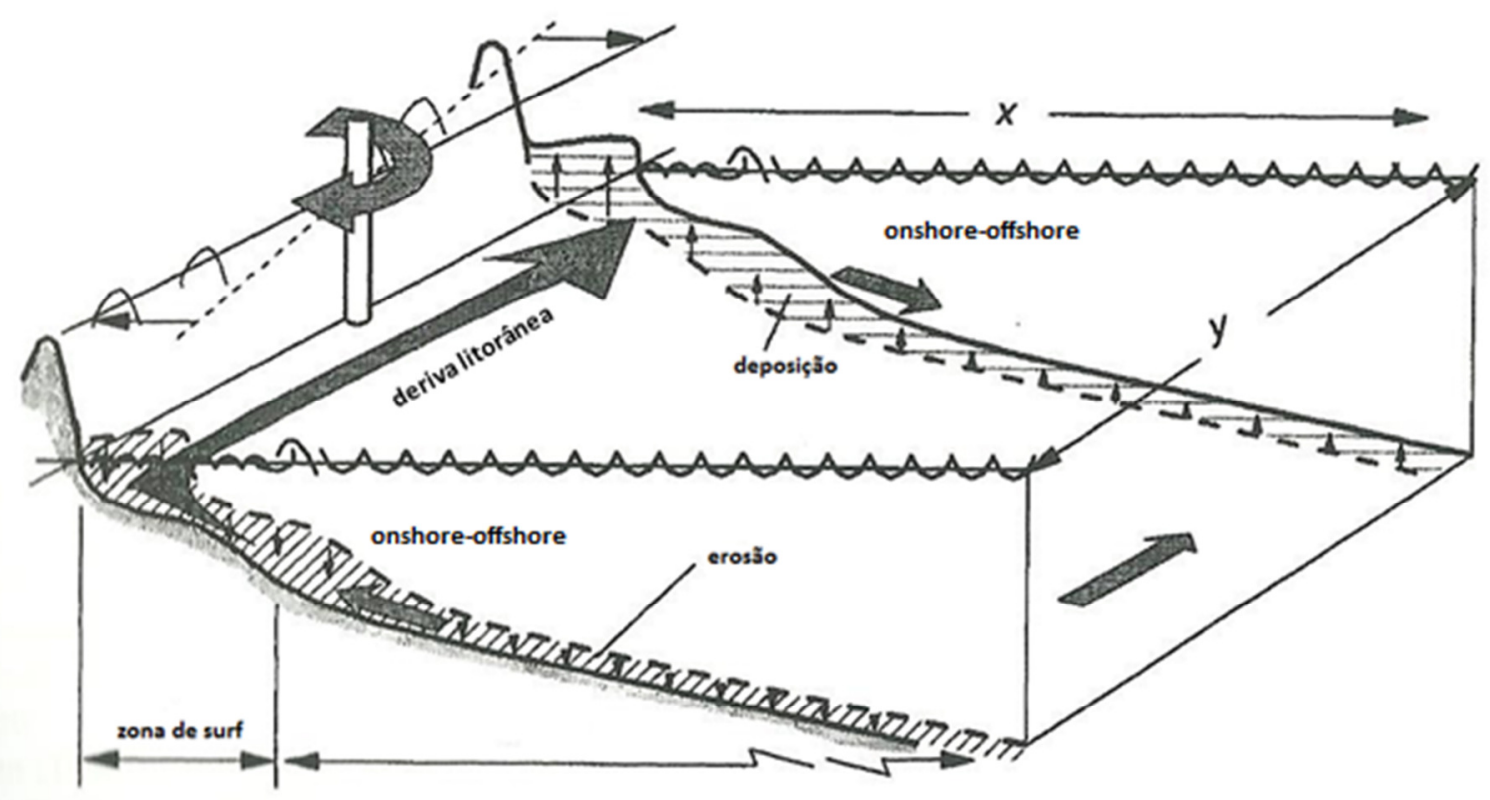

Figura 4: Interação entre as correntes de deriva litorânea, ocorrendo no sentido longitudinal a linha de costa, e correntes onshore-offshore, atuando perpendicularmente a face praial. (Adaptado de Short, 1999). 


\subsubsection{Marés}

A variação da maré é um fator muito importante a ser considerado nas variações morfológicas dos sistemas praiais. Em muitos lugares do globo seu efeito pode eclipsar o efeito das ondas se tornando o principal processo modelador da zona costeira. Sua dominância se revela pela formação de planícies de maré ao invés de praias.

De modo geral a maré atua como uma força moduladora dos processos da zona de surf, promovendo a migração das zonas subáreas praiais através da variação diária do nível do mar. Sua capacidade de transporte direto de sedimentos, por meio das correntes de maré vazante e enchente também não pode ser menosprezada (Short, 1999). A influência das marés é menos elucidada que o efeito das ondas devido a restrição geográfica das maiores amplitudes de maré.

Os efeitos da variação da maré aumentam proporcionalmente com o aumento de sua intensidade, sendo a zonas litorâneas ao redor do globo classificadas popularmente em três categorias de regimes de maré: micro maré - variação menor que 2 m; meso maré - variação entre 2 e 4 m e macro maré - variação maior que $4 \mathrm{~m}$.

Outro aspecto importante da variação da maré é a elevação do lençol freático na face praial, saturando de água o sedimento e consequentemente diminuindo sua permeabilidade. Apesar de não existirem resultados conclusivos, existem estudos como Turner \& Masselink (1998) que apontam um aumento no transporte sedimentar durante situações de saturação aquosa na faixa de areia. A variação da maré acaba por definir a quantidade de tempo em que uma praia se encontra saturada ou não. 
Masselink (1993) estudou o efeito das marés na morfodinâmica dos sistemas praiais, seus resultados demonstram que com o aumento da variação das marés as praias tendem a ser mais largas, apresentar um gradiente de inclinação menor e exibirem menos feições morfológicas associadas a dinâmica das ondas.

\subsubsection{Elevação do Nível do Mar}

Os processos de recuo e avanço do nível relativo do mar (NRM) atuam no planeta desde sua formação, causando construção e destruição de ambientes costeiros ao longo do tempo. Existem muitos processos responsáveis por variações do NRM, podendo ser classificados em processos globais, como os ciclos glaciais planetários, ou locais como alterações no estoque de sedimentos e movimentos de subsidência e elevação da crosta terrestre.

Os efeitos das oscilações do nível mar variam muito localmente, estando sujeitos ao efeito de características como a declividade da plataforma continental e da costa, estoque e características dos sedimentos, feições morfológicas (cordões litorâneos, ilhas barreira, pontais, planícies de cristas de praia, tombolos), grau de exposição à ação das ondas, presença de aporte fluvial e presença de formações rochosas.

Nos últimos anos foi detectada uma aceleração adicional da elevação do NRM, atribuída à expansão térmica da água do mar e o aporte de água doce provindo do derretimento das geleiras polares causados pela recente elevação das temperaturas atmosféricas (Church \& White, 2006).

A real amplitude de tal aceleração ainda não foi definida, sendo que atualmente existem estimativas globais de que o NRM aumenta em uma taxa 
de cerca de 2 mm/ano (Holgate \& Woodworth, 2004; Church \& White, 2006). Estudos na costa brasileira indicam um aumento em torno de $4 \mathrm{~mm} / \mathrm{ano}$ (Mesquita, 2003). Jevrejava et al. (2008) apresentam uma aceleração média global de $0,001 \mathrm{~mm} / \mathrm{ano}^{2}$ para o período entre 1700 e 2003, obtendo por simples extrapolação um aumento de $34 \mathrm{~cm}$ do NRM para o período entre 1990 e 2090.

Tal processo de elevação inunda áreas mais próximas da linha de costa e faz com que a ação dos trens de ondas atinja cotas mais elevadas, provocando ocasionalmente erosão e, por conseguinte, perda de terreno. Como já mencionado, os efeitos e amplitudes de tal processo são muito variáveis, sendo fortemente condicionada pelas características locais dos ambientes. A perda de terreno pode variar desde cerca de $1 \mathrm{~m}$, para ambientes rochosos consolidados muito inclinados, até centenas de metros para ambientes praiais de baixa declividade (Muehe, 2001).

\subsubsection{Ação das tempestades}

Tempestades são eventos atmosféricos extremos que podem atuar como agentes erosivos nos sistemas costeiros por meio do incremento da altura e do período dos trens de ondas atuantes e por um aumento adicional no nível do mar, chamado de maré meteorológica (Barletta \& Calliari, 2003). Tais eventos são intensificados quando ocorrem simultaneamente com o pico positivo da maré astronômica, caracterizando as chamadas "ressacas", normalmente associadas a grande perda sedimentar e também enorme prejuízo material em áreas costeiras densamente urbanizadas (Campos et. al., 2009).

As tempestades normalmente causam erosão em toda a extensão de 
área emersa do sistema praial, desde a face praial até as escarpas e dunas. $\mathrm{O}$ sedimento empilhado nesse setor acaba por se espalhar pela face litorânea e costa afora, deslocando o início da zona de espraiamento e até mesmo a profundidade basal das ondas. O tempo de recuperação do sistema depende da intensidade e frequência dos eventos. A figura 5 indica um tempo de recuperação de aproximadamente 10 anos da zona subárea da praia de Moruya, no SE da Austrália, após a incidência de uma série de tempestades extremas durante 1974/75 (Cowell \& Thom,1994 apud Short, 1999)

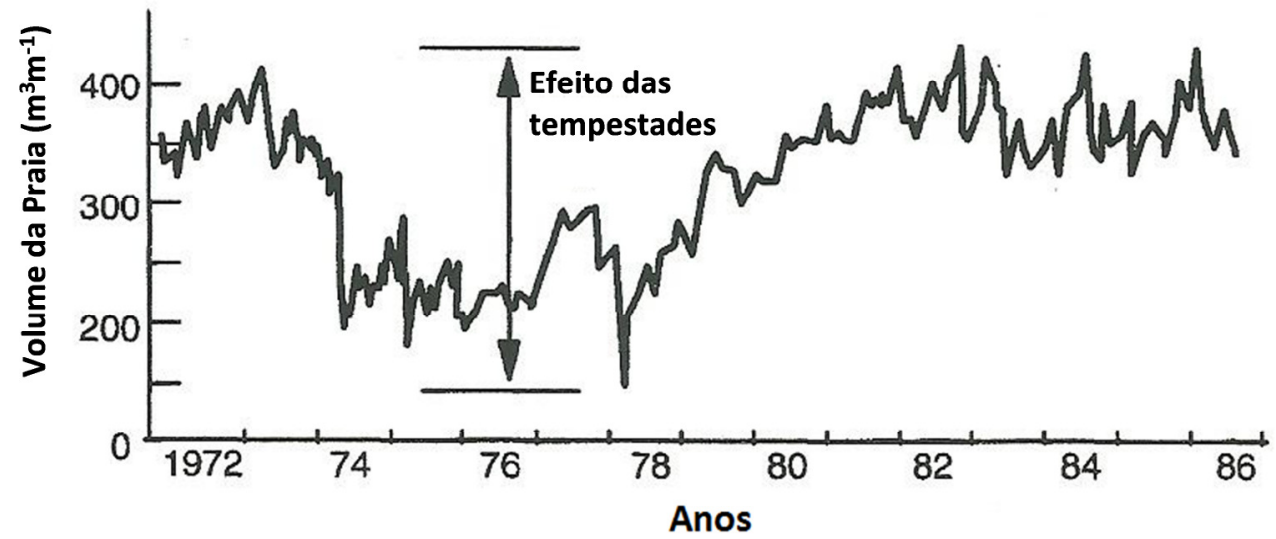

Figura 5: Série temporal da variação do volume da porção subaérea da praia de Moruya, no SE da Austrália, a partir de medições de campo. Notar a recuperação praial após a incidência de tempestades muito severas durante 1974. Adaptado de Short (1999).

Os efeitos da passagem desses fenômenos são potencializados pelas chamadas marés meteorológicas (strom surges). Tais fenômenos são classificados como oscilações de baixa frequência do nível do mar resultantes da soma entre a ação de ventos, wind set-up, e variações da pressão atmosférica, barometric set-up (Truccolo et al., 2006).

Ainda segundo Truccolo et al. (2006), o efeito do wind set up é responsável por até $90 \%$ destas oscilações e pode ser explicado pela teoria de Ekman. O vento longitudinal causa um gradiente barotrópico no sentido 
perpendicular a plataforma continental, que é balanceado pelo gradiente geostrófico do planeta, resultando em um deslocamento de água também no sentido perpendicular a plataforma continental. A Força de Coriollis acaba por determinar a direção na qual a água se deslocará. No hemisfério sul seu efeito faz com que o transporte de Ekman ocorra para esquerda do sentido do movimento do fluxo em questão, desta forma os ventos provindos do quadrante S/SE normalmente são os causadores das elevações do nível do mar na costa brasileira.

As variações da pressão atmosférica associadas aos eventos atmosféricos extremos causam uma resposta isostática do nível do mar, ou seja, uma queda na pressão atmosférica resulta em um aumento no nível do mar. Tal situação é conhecida com "fenômeno do barômetro inverso" e segundo Benavente et al.(2006) se pressões baixas puderem persistir por tempo suficiente, o nível d'água aumentará cerca de 0,10 $\mathrm{m}$ para cada queda de $10 \mathrm{hPa}$ abaixo da pressão barométrica normal (1013 hPa), totalizando $1 \mathrm{~cm}$ por milibar de pressão.

Infelizmente, ainda não existem resultados conclusivos a cerca dos efeitos do atual aquecimento global sobre as tempestades, principalmente no hemisfério sul do planeta, onde dados observados são mais escassos (Wang et al, 2006). Entretanto existem alguns estudos apontando um possível aumento na intensidade dos eventos atmosféricos extremos em todo o globo, especialmente os ciclones extratropicais do Atlântico Sul, como o evento conhecido como Furacão Catarina que ocorreu em 2004 (Emanuel, 2005; Pezza \& Simmonds, 2005; Veiga et. al., 2008). 


\subsection{Estudos abordando a morfodinâmica dos sistemas praias}

\subsection{1 - Breve Histórico do Desenvolvimento dos Principais Métodos}

Os trabalhos pioneiros sobre a morfodinâmica praial tinham um enfoque mais descritivo, baseado na observação visual das feições morfológicas e das ondas atuantes em conjunto com observações da textura e granulometria dos sedimentos. No entanto conceitos como a modificação do fluxo sedimentar em função da alteração na energia das ondas já começavam a surgir (Johnson, 1919 apud Hoefel 1995).

Emery (1961) desenvolveu uma metodologia para observar variações nas feições praias a partir de perfis transversais obtidos pelo meio de balizas e um nível topográfico. Tal método prima pela simplicidade e precisão, possibilitando uma boa descrição do ambiente praial quando replicado com frequências temporais e espaciais adequadas. Sua influência persistiu em muitos trabalhos sendo utilizado até os dias atuais.

Sonu \& Van Beek (1971) introduziram conceitos de sazonalidade que associavam as estações do ano com a quantidade de sedimentos depositados na porção subaérea em praias localizadas nas médias e altas latitudes. As condições de acresção foram relacionadas ao verão ("perfis de verão") enquanto as condições de erosão com o inverno ("perfis de inverno"). Komar (1976) estendeu essa relação às zonas de baixa latitude, que não apresentam ritmicidade climática, modificando a nomenclatura para "perfis de tempo bom" (swel) e de "tempestade" (storm).

Com a evolução das técnicas de amostragem e aparecimento de experimentos em laboratório, começaram a surgir modelos quantitativos dos processos responsáveis pelas variações no ambiente praial. Dean (1973) 
apresentou um modelo que relacionava a velocidade de queda de um grão de areia na coluna d'água com a esbeltez $(H / L)$ de uma onda, expresso pela seguinte equação:

$$
\Omega=H / L=1,7 . \pi \cdot w_{s} / g . T
$$

Onde,

$\mathrm{H}=$ altura da onda;

$\mathrm{L}=$ comprimento da onda;

$\pi=3,14$

$\mathrm{w}_{\mathrm{s}}=$ velocidade de queda de partícula na coluna d'água;

$\mathrm{g}$ = aceleração da gravidade;

$\mathrm{T}$ = período da onda;

$1,7=$ coeficiente determinado empiricamente.

Este parâmetro adimensional pode ser interpretado fisicamente como a indicação de que um grão de areia, colocado em suspensão pela passagem de uma onda, pode, ou não, sedimentar durante o tempo em que o fluxo de água é induzido pela propagação da onda em direção à praia (Calliari et al., 2003).

Fazendo uma associação geral com o padrão de ondas, pode se dizer que ondas mais energéticas, ou seja, mais esbeltas, tendem a criar fluxos d'água em direção à praia que impossibilitam a sedimentação dos grãos, fazendo com que estes sejam levados em suspensão em direção ao mar aberto, criando assim uma situação de erosão. Por outro lado ondas menos energéticas normalmente não conseguem criar fluxos competentes o suficiente para impedir a sedimentação dos grãos na praia, criando uma situação desposicional.

Outro modelo que se tornou importante foi o apresentado por Guza \& 
Inman(1975), que introduz o parâmetro dimensionador do surf, surf scalling parametrer, $(\varepsilon)$, representado pela seguinte equação:

$$
\varepsilon=\text { ai.w }^{2} / g \cdot \operatorname{tang}^{2} \beta
$$

Onde:

ai = amplitude da onda na arrebentação $\left(\mathrm{H}_{\mathrm{b}} / 2\right)$;

$W^{2}=$ frequência angular da onda incidente $(2 \pi / T)$;

$\mathrm{g}$ = aceleração da gravidade;

$\tan \beta=$ declividade do perfil praial.

A equação relaciona os fenômenos físicos ocorridos na zona de surf com a morfologia da praia durante a ação dos trens de onda.

Os dois parâmetros apresentados acima foram muito importantes para o desenvolvimento de sistemas quantitativos de classificação e predição dos sistemas praias, constituindo a base tanto para a engenharia costeira quanto para estudos de cunho mais acadêmico (Cazzoli, 1997).

Historicamente pode se destacar duas principais correntes de estudo da morfologia praial: a escola norte americana e a chamada Escola Australiana de Geomorfologia Costeira. A primeira apresenta um foco mais voltado à engenharia costeira, sendo baseada principalmente nas publicações da U. S. Army Coastal Engineering Research Center - CERC de 1973 e 1993, enquanto a segunda tem um cunho mais acadêmico e se caracteriza pela aplicação da metodologia exposta nos diversos trabalhos desenvolvidos principalmente por Wrigth e Short (Wright et al., 1978; Wright et al., 1979; Short, 1979a; Short 1979b; Short \& Wright, 1981; Short, 1981; Wright et al.,1982; Wright \& Short, 1983; Wright \& Short, 1985).

Os trabalhos publicados pelo CERC apresentam uma metodologia 
baseada em levantamentos pontuais e detalhados da face praial (levantamentos topográficos, caracterização geológica-geomorfológica) aliados a estudos das condições hidrodinâmicas atuantes (caracterização do ângulo, altura e direção das ondas, correntes, marés, entre outros). Outra faceta importante sobre os trabalhos do CERC é o pioneirismo na implementação de ferramentas computacionais nas análises e predições sobre a morfodinâmica praial (Cazzoli, 1997).

A Escola Australiana de Geomorfologia Costeira é responsável pela metodologia de classificação do estado morfológico praial mais aceita e utilizada. A metodologia tem como base estudos realizados principalmente por Wrigth e Short no final da década de 70, em localidades da costa sudoeste australiana. Os ambientes abordados estavam expostos a ondulações de energia moderada a alta, compreendidos no regime de micro maré e apresentavam graus de exposição, compartimentação e variabilidade temporal diferentes.

Em Wrigth \& Short $(1983,1985)$ os autores definiram um sistema de classificação de praias baseados na concepção de "estados" ou "estágios" morfológicos distintos associados a regimes hidrodinâmicos caraterísticos. Os autores estabeleceram um total de 6 estágios, caracterizados por dois estados extremos (estado dissipativo e estado refletivo) e quatro estados intermediários.

O já mencionado parâmetro dimensionador de surfe $(\varepsilon)$ (Guza \& Inman, 1975) foi incorporado à descrição para distinguir estágios praiais conforme a razão entre a forma das ondas e a declividade da praia.

O estado dissipativo apresenta uma grande zona de surf bem 
desenvolvida graças à atuação de ondulações energéticas e/ou sedimentos de granulometria fina. Apresenta baixo gradiente topográfico e elevada presença de sedimentos na zona subaquosa. A arrebentação normalmente é do tipo deslizante (spilling), podendo apresentar correntes de retorno associadas às variações na altura de onda na arrebentação. Devido ao baixo gradiente topográfico o run-up na face praial é reduzido (entende-se por run-up o máximo deslocamento vertical do espraiamento na face da praia) e o parâmetro dimensionador de surf se mantem sempre acima de 20 , chegando facilmente a valores como 400.

O estado refletivo apresenta uma zona de surf restrita e um grande gradiente topográfico, está associado a praias confinadas com sedimentos grossos ou ambientes que experimentaram grandes períodos de acresção. Os sedimentos se encontram estocados na zona subaérea e ao contrário do estado dissipativo o run up é máximo, fato que normalmente acarreta na geração de feições rítmicas na face praial. A arrebentação predominante é do tipo mergulhante (pluning) ou ascendente (surging) e o parâmetro dimensionador do surf se mantém sempre abaixo de 3.

Os estados dissipativo e refletivo correspondem aos extremos da variação na escala proposta e são associados respectivamente a condições erosivas e deposicionais, entre eles se encontram os estados intermediários que apresentam elementos de ambos estados.

De forma resumida pode se dizer que a evolução dos estágios intermediários são explicados pela migração do banco de areia submerso, presente no estrado dissipativo, em direção a praia devido as variações hidrodinâmicas, ocasionando a diminuição da calha longitudinal, até essa 
finalmente se soldar a face praial no estado refletivo. A figura 6 exibe de forma sintética a evolução dos estágios.

a) DISSIPATIVO

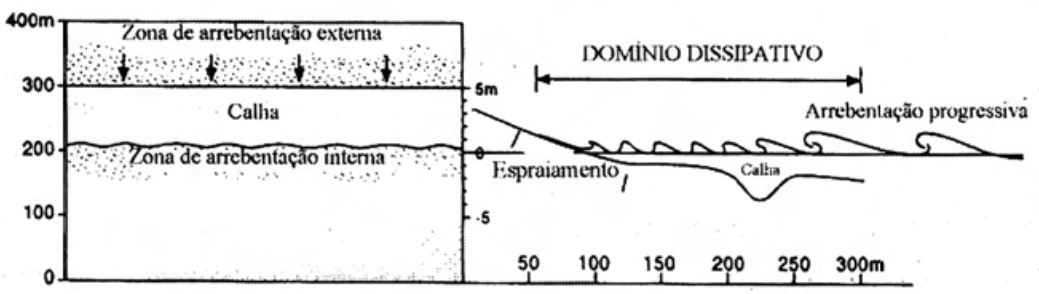

b) BANCO E CALHA LONGITUDINAL.

INTERMEDIÁRIO

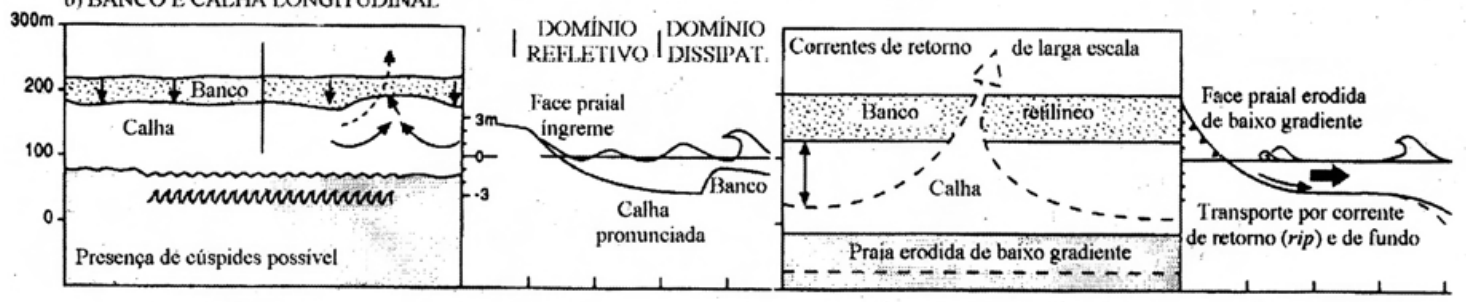

c) BANCO E PRAIA DF CÚSPIDES
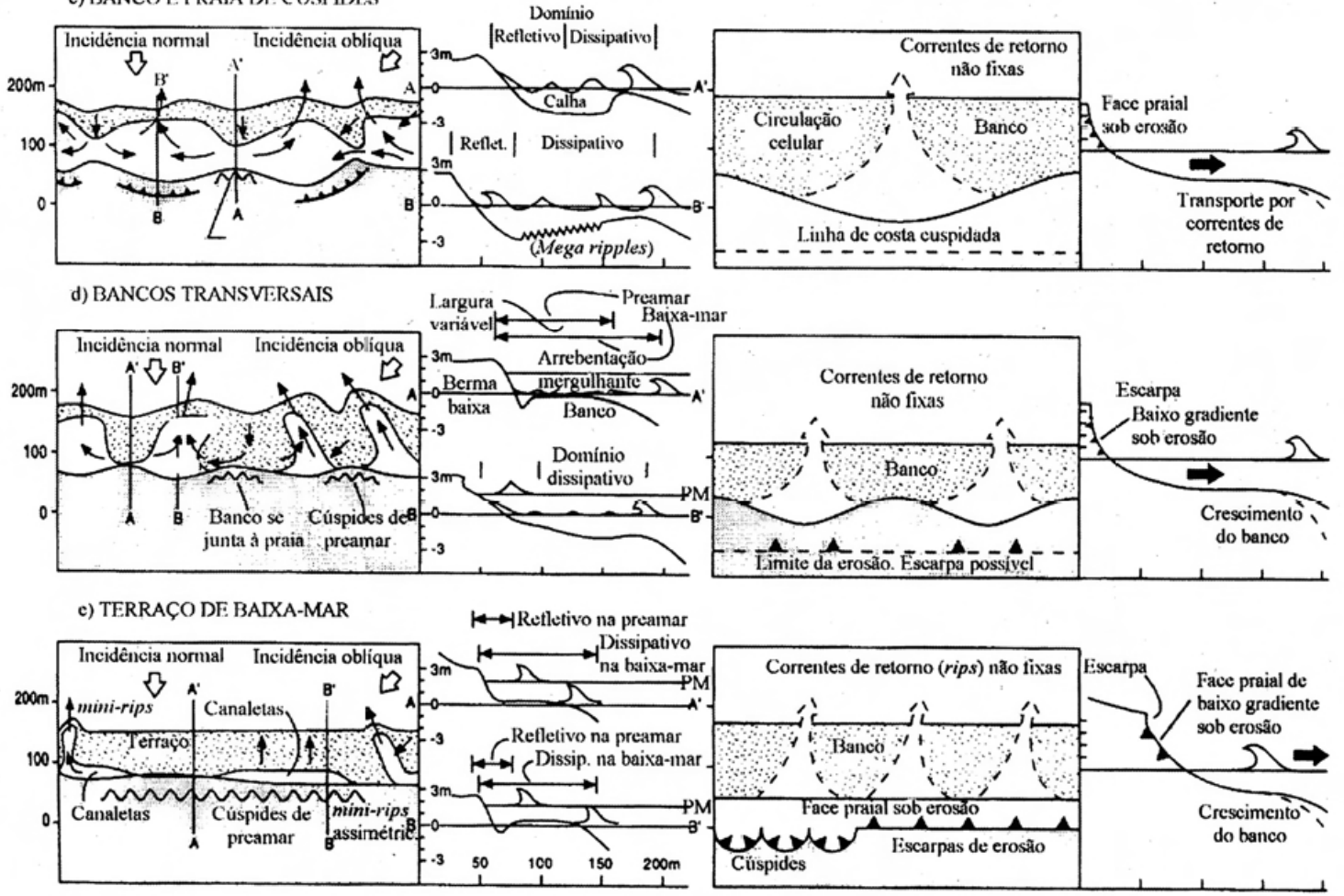

e) REFLETIVO
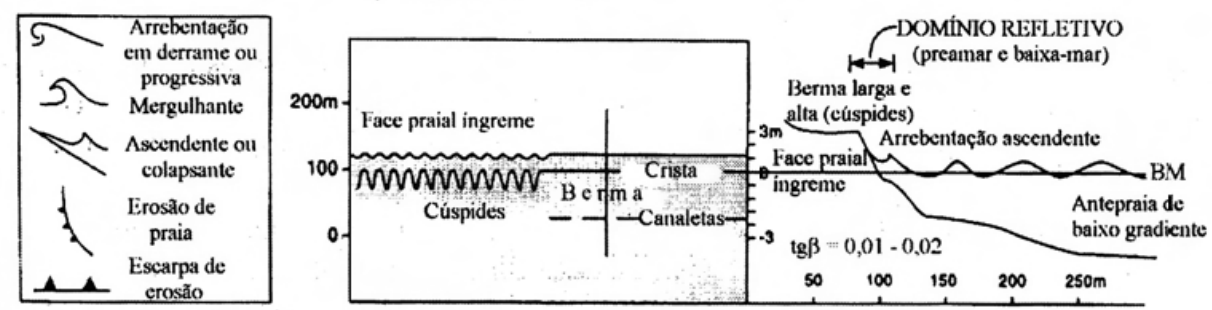

Figura 6: Características dos diversos estados praias para condições de ondas construtiva (lado esquerdo) e erosivas (lado direito). Extraído de Calliari et al., 2003. 
A aplicação da classificação morfodinâmica envolve a determinação do seu estado mais frequente, ou modal, por meio de sucessivas medições em situ dos parâmetros envolvidos. Dependo da variação dos fatores ambientais, como o clima de ondas, dos ventos, maré e características e quantidade de sedimentos, uma praia pode apresentar variações em seu estado modal. A fim de relacionar o estado morfológico da praia, a variação das ondas incidentes e das características sedimentares, Wright \& Short (1985) utilizaram o parâmetro adimensional ômega $(\Omega)$ de Dean (1973) para estabelecer a seguinte equação:

$$
\Omega=\mathrm{H}_{\mathrm{b}} / \mathrm{w}_{\mathrm{s}} . \mathrm{T}
$$

onde:

$\mathrm{H}_{\mathrm{b}}=$ altura significativa da onda na arrebentação;

$\mathrm{W}_{\mathrm{s}}=$ velocidade média de decantação dos sedimentos da face da praia;

$\mathrm{T}=$ período médio das ondas.

Com tal relação foi possível identificar a "migração" de uma determinada praia entre os diferentes estados morfodinâmicos em direção a seu estado modal. Cabe ressaltar que as tais variações estão associadas a exposição a diferentes valores de Hb e são características de ambientes praiais intermediários. Na figura 7 se encontra o gráfico relacionando os valores de $\Omega$ com os diferentes estados morfodinâmicos. 


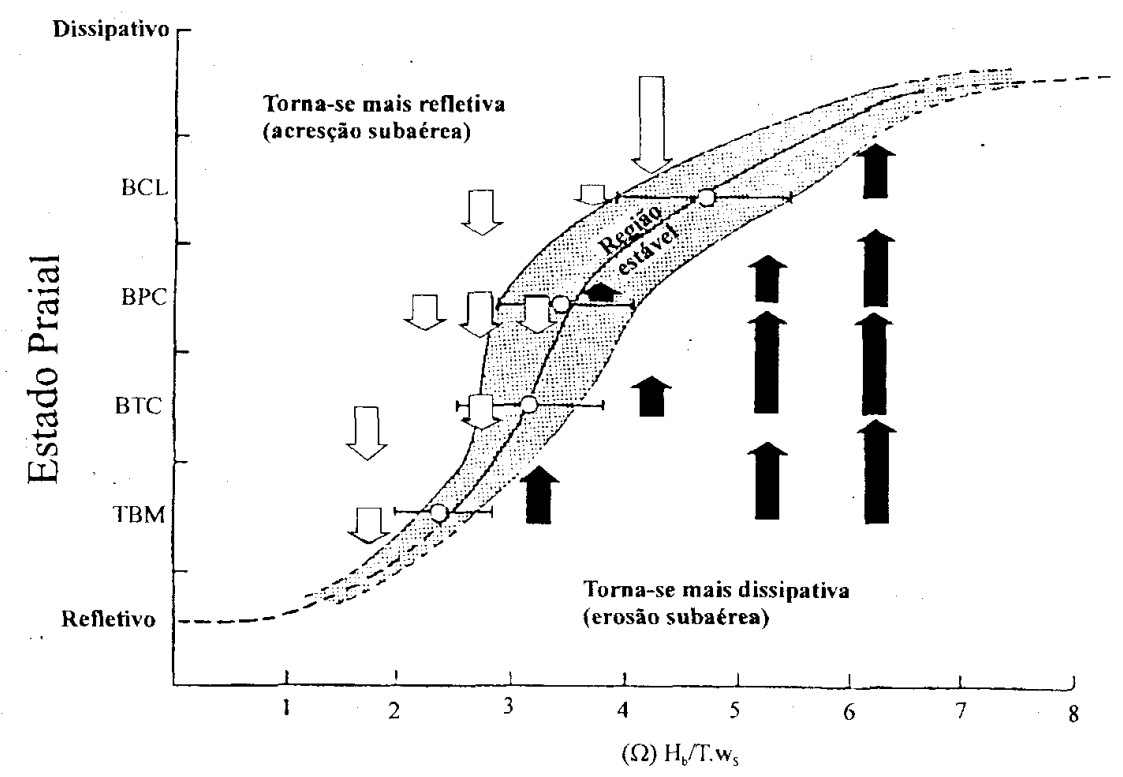

Figura 7: Estabilidade dos estados praias, sua direção e taxa de mudanças em função de

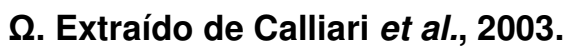

O mérito da metodologia reside na quantificação e na possibilidade de predição dos futuros estados morfológicos. Em termos práticos é possível inferir com base em parâmetros de simples medição e cálculo se uma praia se encontra em uma tendência acresciva ou erosiva.

As principais deficiências do método estão ligadas ao ambiente onde este foi concebido. Os resultados demonstram que a escala é adequada para praias com um banco arenoso, submetidas a um regime de micro maré e clima de ondas de moderada ou alta energia. Este método foi testado em outros tipos de praias, sem resultados tão efetivos. Um exemplo disto é a dificuldade encontrada é a tentativa de adaptação da metodologia em sistemas praias com múltiplos bancos (Aagaard, 1991; Short, 1992 e Short \& Aagaard, 1993). Os autores chegaram a propor um modelo relacionado ao parâmetro $\Omega$, porém ainda existem problemas relacionados à diminuição da altura das ondas devido a disposição dos bancos. 
A variação da maré é um fator muito importante a ser considerado nas variações morfológicas dos sistemas praiais, especialmente em praias submetidas a regimes de meso e macro maré. Com intuito de avançar no desenvolvimento da metodologia de classificação de praias, Short (1991) e Masselink \& Short (1993) criam um modelo conceitual adicionando uma relação entre a amplitude de variação da maré e altura significativa das ondas na arrebentação (Relative Tide Range Parameter, RTR) ao modelo proposto por Wright \& Short (1985).

O modelo tenta estabelecer o grau de importância da variação da maré na hidrodinâmica praial com base em sua amplitude, associando os valores de $\Omega$ e RTR aos estados morfológicos já definidos. Infelizmente, ainda existem poucos dados sobre os processos hidrodinâmicos que ocorrem nas praias expostas a grandes variações de maré, tornando o modelo proposto um primeiro passo nos estudos desses ambientes.

A classificação de Writgth \& Short $(1983,1985)$ vem sendo aplicada em diferentes partes do mundo. Atualmente alguns autores vêm adaptando-a para ambientes com diversos regimes de ondulações e de variação de maré (Benavente et al., 2002; Gómez-Pujol et al., 2007; Sénéchal et al., 2009, entre muitos outros).

\subsection{2 - Estudos Enfocando a Morfodinâmica Praial na Costa do Brasil}

No Brasil existem vários trabalhos realizados ao longo de toda costa, utilizando metodologias variadas, com o uso de perfis topográficos, análises sedimentares, caracterização do regime de ondas, análises de fotos aéreas, imagens de satélite, geoprocessamento, análises de isótopos radioativos, e 
mais recentemente modelagem numérica (Cazzoli, 1997). Cabe ressaltar os estudos realizados no sul do país desde o início dos anos 90, nos quais se encontram elementos da metodologia proposta por Wright \& Short $(1983,1985)$, além de análises dos processos meteorológicos atuantes, caracterização sedimentar e imagens aéreas (Calliari \& Klein,1993; Toldo Jr et al., 1993; Klein \& Menezes, 2001; Esteves et al., 2002; Tabajara et al., 2004; Figueiro \& Calliari, 2006; Tagliani et al., 2006; Siegle \& Calliari, 2008; Parise et at., 2009; Freitas et al., 2010; Pereira et al., 2010; entre outros).

Pode se destacar também o litoral fluminense, que conta com estudos sobre morfodinâmica praial desde o final da década de 70 . Os trabalhos também levam em conta parâmetros da metodologia da escola australiana, análises dos padrões meteorológicos, imagens aéreas e modelagem numérica. (Muehe \& Dobereiner, 1977; Muehe 1979; Muehe \& Corrêa, 1989; Muehe \& Albino, 1992; Machado \& Muehe, 2005; Muehe et al., 2005; Fernandez et al., 2006; Savi, 2007; Silva et al., 2008; Muehe, no prelo; entre outros).

\subsection{3 - Estudos Enfocando a Morfodinâmica Praial no Litoral}

\section{Paulista}

Em ralação ao estado de São Paulo podemos destacar os trabalhos de Cazzoli (2000), Martins (2000, 2006), Barros \& Tessler (2003), Karniol-Marques (2007), Nuber (2008) e Rogacheski (2010).

Cazzoli (1997) efetuou um estudo sobre duas praias do município de Itanhaém, sul do litoral paulista, a praia de Cibratel e Itanhaém-Suarão. Foi realizado um monitoramento do prisma praial por meio de perfis topográficos e coletas de sedimento ao longo de 14 meses, além da caracterização visual das ondas e análise das condições meteorológicas durante o período. 
$\mathrm{Na}$ praia de Cibratel os resultados demonstram que o transporte predominante foi o on shore - off shore (costa adentro- costa afora), com deriva litorânea rumo NE mais efetiva, direção essa associada a passagem de sistemas frontais (frentes frias). A praia de Itanhaém-Suarão foi subdividida em dois setores devido a presença da influência do Rio Itanhaém. O transporte de sedimentos se deu pela alternância da ação da corrente on shore - off shore e da deriva litorânea com rumo NE, também associada a passagem de frentes frias. De modo geral a autora concluiu que o processo de transporte de sedimento é condicionado em função das alterações meteorológicas, que causam variações nos trens de onda incidentes na face praial.

Em estudo sobre as variações morfológicas de curto período sobre a face praial, Martins (2000) fez uso de perfis topográficos para monitorar a praia de Bertioga, no município de mesmo nome localizado no litoral central paulista, em conjunto com coleta de sedimentos, caracterização visual das ondas incidentes e análise das condições meteorológicas. Os resultados apontaram para a influência da passagem dos sistemas frontais como explicação das modificações nos processos sedimentares. No primeiro momento do levantamento o transporte on shore - off shore foi identificado como o processo predominante no transporte de sedimentos, na segunda fase, sob atuação de uma frente fria, a deriva litorânea rumo SW foi caracterizada como processo predominante.

Em 2006, a mesma autora realizou estudos sobre os processos sedimentares na praia da Sununga, no município de Ubatuba localizado no norte do litoral paulista. Para tanto a autora fez uso de perfis topográficos obtidos por meio do RTK-GPS, análise do espectro de ondas por meio de 
dados de ondógrafos e modelos numéricos, caracterização dos eventos atmosféricos ocorridos, dados batimétricos e análises sedimentares.

Os resultados revelaram que a morfodinâmica local é fortemente ligada ao processo de rotação praial, ou seja, a alternação de setores em acresção e erosão ao longo do sistema praial. Tal processo está ligado à morfologia restrita desse sistema, cuja configuração pode ser classificada como uma praia de bolso, limitada por maciços rochosos. O mecanismo iniciador do processo de rotação praial foi identificado nos diferentes processos meteorológicos atuantes, sendo os ciclones extratropicais associados a situações erosivas e à instalação do Anticiclone Tropical do Atlântico Sul (ATA) a situações construtivas.

Barros \& Tessler (2003) avaliaram a morfodinâmica das praias da Fazenda, Puruba e Itamambuca localizadas no setor norte do município de Ubatuba. O estudo foi efetuado por meio de perfis topográficos mensais durante 14 meses em conjunto com coletas de sedimento e caracterização das ondas incidentes e dos sistemas meteorológicos atuantes. Os autores também associaram as modificações nos processos sedimentares aos diferentes sistemas meteorológicos presentes durante as coletas, relacionando as ondas de NE e N, formadas pelo ATA, a situações construtivas e as ondas de S e SE, associadas a ciclones extratropicais, a processos erosivos.

A magnitude da resposta aos processos meteorológicos observados variou com a orientação dos sistemas praiais e seus graus de compartimentação e exposição. A praia da Fazenda se encontra mais abrigada das ondulações provindas de $\mathrm{NE}$ e $\mathrm{N}$, aumentando o seu tempo de recuperação depois de um evento erosivo. A praia de Puruba apresentou uma 
rápida resposta tanto a processos erosivos quanto construtivos, mesmo se encontrando relativamente protegida das ondas de S e SE. Porém, a circulação sedimentar se mostrou influenciada pela sazonalidade da descarga fluvial, promovida pela variação do volume de chuvas. A praia de Itamambuca apresentou respostas diretas na deriva longitudinal dos sedimentos quando submetida a mudanças na orientação dos trens de ondas incidentes devido ao seu maior grau de exposição as diferentes ondulações.

O trabalho de Karniol-Marquez (2007) foi realizado em trecho no sul do município de Ilha Comprida, localizado no extremo sul do litoral paulista. A autora usou o DGPS para obter perfis topográficos do setor em questão entre os anos de 2005 e 2006, além de efetuar coletas de sedimentos e utilizar métodos geofísicos para identificar as feições presentes na zona submersa do sistema praial.

Os resultados foram analisados com base nos sistemas meteorológicos atuantes e nos trens de ondas incidentes no período de monitoramento. As conclusões apontaram as ondas de S com período médio entre 7 e 8 segundos e com até $1 \mathrm{~m}$ de altura como atuantes no processo de engorda da feição emersa. Com o aumento do período médio para entre 8 e 10 s e a altura para 1,5 $\mathrm{m}$ as ondas de mesma direção passaram a exercer influência erosiva. De forma, inversa as ondas de $E$ com período entre 6 e $8 \mathrm{~s}$ e com até $1 \mathrm{~m}$ de altura exerceram papel erosivo, enquanto ondas da mesma direção e com 1,5 $\mathrm{m}$ de altura e período médio entre 6 e $7 \mathrm{~s}$ exerceram papel construtivo. Tal padrão é incongruente com os dados da literatura, podendo ser explicado por um possível atraso no tempo de resposta desse sistema praial.

Novamente as diferentes ondulações são atribuídas à passagem de 
diferentes sistemas frontais, sendo ATA vinculado às ondas de $\mathrm{N}$ e NE, e os ciclones extratropicais são vinculados às ondas S, SE e ocasionalmente a ondas de $\mathrm{E}$.

Nuber (2008) efetuou o monitoramento do sistema praial de Massaguaçú, localizado em Caraguatatuba, litoral norte do estado de São Paulo. O estudo contou com análises de fotos aéreas para definir o padrão de variação da linha costa entre os anos de 1962, 1977, 1994 e 2001, e com perfis praiais obtidos com um DGPS no período entre 2006 e 2008 em conjunto com coletas de sedimentos.

O autor relata que a tendência da praia era acresciva entre 1962 e 1994 e a partir de 1994 até 2006 predominou a tendência erosiva. Os dados de morfologia e sedimentologia demonstraram grande variabilidade espacial e temporal, provavelmente ligadas à variação anual da energia de ondas causada por variações meteorológicas. $\mathrm{O}$ autor ainda classifica $\mathrm{O}$ arco praial em 5 setores diferentes com base na análise de risco a erosão costeira, sendo este mais elevado na porção central e menor nas extremidades.

No mesmo arco praial se deu o estudo de Rogacheski (2010) buscando caracterizar as Zonas de Erosão Acentuada (ZEAs) presentes. O autor utilizou dados batimétricos de ondas incidentes para alimentar dois modelos numéricos, o SWAN, para propagação de ondas em águas profundas, e o SMC, para propagação de ondas em águas rasas, simulação de correntes e de transporte sedimentar.

Os resultados apontaram para dois padrões de ondas distintos atuando no arco praial de Massaguaçú, o primeiro, menos eficaz, está relacionado com as ondas provindas dos quadrantes $\mathrm{NE}-\mathrm{E}$, que geram correntes longitudinais 
para o sul e correntes transversais. Ambas as correntes se mostraram menos significativas para o transporte de sedimentos, além de formar células de circulação em vórtices. O segundo padrão, mais intenso, está associado às ondas oriundas de SSE - SE - ESE, sendo as correntes de deriva resultantes de sentido norte. Estas correntes juntamente com as correntes transversais e células de circulações em vórtices representaram o padrão de modificação morfológico mais competente.

Tais resultados levaram o autor a atribuir a existência das Zonas de Erosão Acentuadas a um possível aumento na frequência e intensidade das tempestades nas últimas décadas, que dura até o presente momento.

\subsection{4 - Estudos Utilizando o Sistema de Posicionamento Global}

\section{Diferencial}

O uso do Sistema de Posicionamento Global (DGPS) se faz presente em vários trabalhos sobre morfodinâmica costeira no Brasil e no mundo, como Estevez et al.(2002) que relata o uso do DGPS no modo cinemático, acoplado a um veículo, para determinar a linha de costa do estado do Rio Grande do Sul entre os anos de 1997 e 2002, e comparando-as com as linhas de costa pretéritas obtidas por fotos aéreas. Os autores destacam a possibilidade de se cobrir grandes distancias com o método devido sua agilidade e praticidade.

Baptista et al.(2008) usaram dois DGPS no modo cinemático acoplados a um quadriciclo para monitorar a trechos de sistemas praiais em Portugal. A partir dos resultados obtidos em campo foram criados Modelos Digitais de Terreno (MDT), para determinar o volume, a declividade do prisma praial, e a localização das feições morfológicas presentes. A vantagem da metodologia aplicada reside na simplicidade e na facilidade do posicionamento dos dados 
aliados a uma precisão relativamente boa. $\mathrm{O}$ erro associado aos MDTs em relação a pontos de controle obtidos simultaneamente com outros DGPS ficou na casa de 0,10 RMS (square mean root-erro quadrático metrico).

Capo et al. (2009) usaram quatro DGPS para estudar as modificações de escala temporal curta associadas a tempestades na praia Truc Vert na França. Dois aparelhos foram usados por pesquisadores a pé na obtenção de perfis topográficos, um aparelho foi acoplado a um quadriciclo e o último foi montado em uma caixa estanque para aquisição de dados nos limites da zona de surf e espraiamento. Os autores usaram os resultados para quantificar os efeitos das tempestades e classificar a praia morfologicamente, o erro associado aos dados ficou abaixo dos $3 \mathrm{~cm}$.

Karniol-Marquez (2007) e Nuber (2008), como já mencionado, também usaram o DGPS para obter perfis topográficos nos seus respectivos locais de estudo. Karniol-Marquez (2007) utilizou o modo estático do aparelho para coletar pontos discretos enquanto Nuber (2008) se utilizou tanto do modo estático quanto do modo cinemático. Os autores elaboram MDTs para avaliação da variação volumétrica, altimétrica e da inclinação da facie praial.

Existem muitos outros exemplos de uso do DGPS na literatura, os pontos em comum apontados pela a maioria dos autores são de grande precisão obtida e a praticidade do manejo em campo, especialmente em áreas de amostragem extensas.

\subsection{Canais de Maré}

Canais de maré, ou inlets, são aberturas que conectam corpos de água protegidos, como lagunas e estuários, com o oceano aberto. Neles ocorrem 
trocas de água, nutrientes, organismos planctônicos, sedimentos e poluentes, exercendo uma grande influência na hidrodinâmica e morfologia locais (CERC, 2002).

Davis e FitzGerald (2004) definem um canal de maré como uma abertura na linha da costa através do qual a água penetra no continente, deste modo proporcionando uma conexão entre o oceano e baías, lagunas, pântanos e sistemas de canais de maré, sendo o canal principal primariamente mantido pelo fluxo das correntes de maré. Na prática, qualquer abertura localizada na costa variando de poucos metros até muitos quilômetros pode ser considerada um canal de maré, até mesmo grandes desembocaduras fluviais podem ser incluídas nesta classificação.

Do ponto de vista econômico os canais de maré são utilizados há muito tempo como vias de navegação para entrada e saída de portos, visto que regiões protegidas são locais adequados para tal atividade. Do ponto de vista biológico as características intermediárias desses ambientes favorecem 0 aparecimento de florestas de manguezal e marismas, proliferação de organismos planctônicos e predadores associados, como peixes e aves, bem como refúgios para reprodução dos últimos.

As características dos canais de maré podem diferir grandemente. Muitos fatores podem determinar sua forma e dinâmica, como regime de ondas, marés e ventos e características geológicas, como o gradiente de inclinação do embasamento rochoso, afloramentos próximos, geometria da bacia do corpo de água, drenagens continentais e características sedimentares (CERC, 2002).

Apesar da grande variação local, existem algumas feições morfológicas 
comuns a maior parte dos canais de maré, sendo as mais importantes:

- Canal Principal ou Garganta: normalmente localizado no centro do canal de maré, é onde por onde a maior parte da água flui durante o ciclo de maré. Na maioria dos canais de maré o canal principal tende a ser estreito e abrigar as maiores profundidades, e graças às velocidades mais intensas exibe a tendência de não acumular sedimentos (Hayes, 1980).

- Delta de Maré Vazante - trata-se do acúmulo de sedimentos transportados pelas correntes de maré vazante, localiza-se na porção marítima do sistema, sendo suas características localmente muito variáveis.

- Delta de Maré Enchente - trata-se do acúmulo de sedimentos transportados pelas correntes de maré enchente, localiza-se na porção interna do sistema, sendo suas características localmente também muito variáveis.

As figuras 8 e 9 ilustram as feições comuns presentes em canais de maré e as correntes associadas aos seus processos de formação. Notar na figura 9 a presença de correntes em direção ao continente mesmo durante a maré vazante, tal condição é atribuída as ação de trens de ondas e difere grandemente em ambientes diverso, de acordo com as condições locais. 


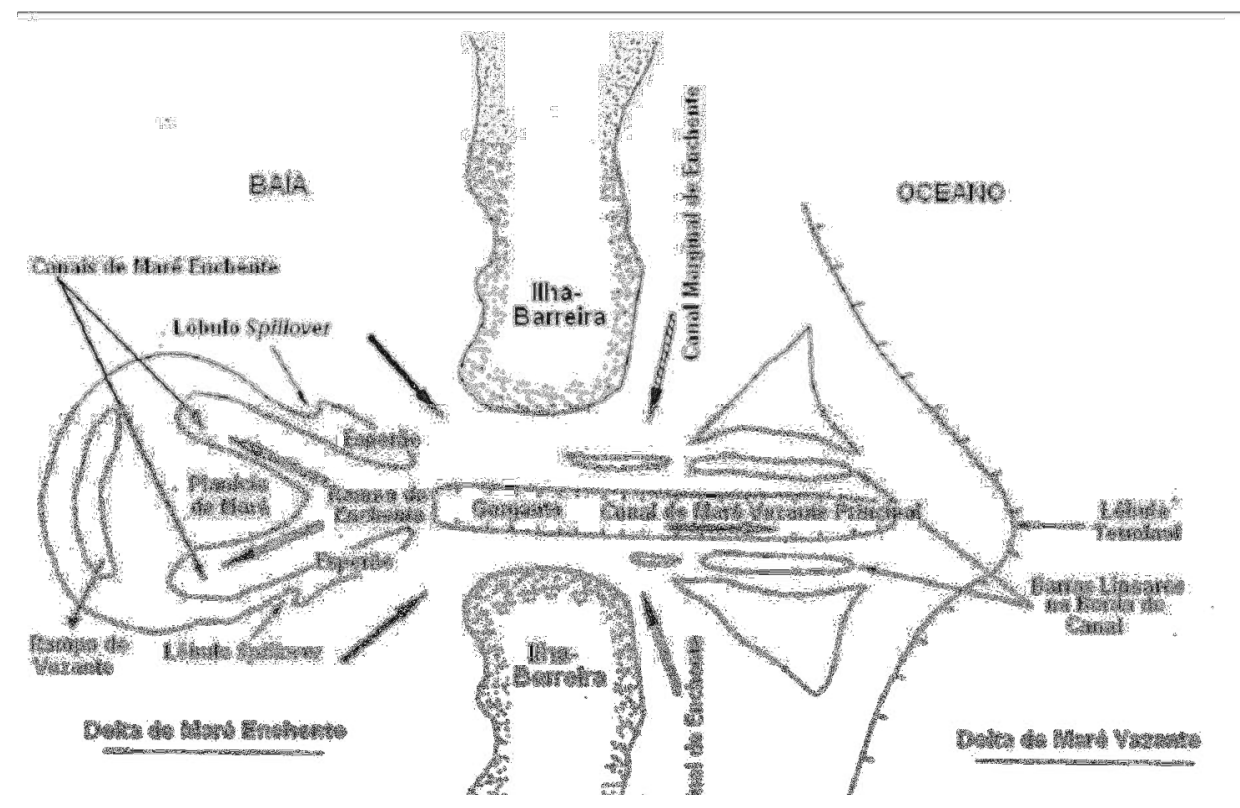

Figura 8: Principais componentes de uma desembocadura, (modificado de Boothroyd 1985; CERC 2002).
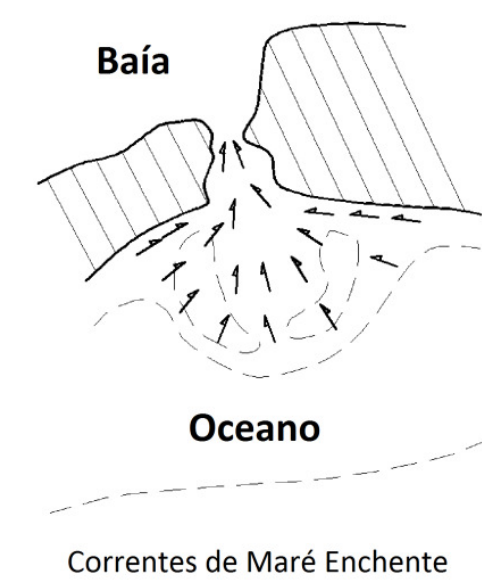

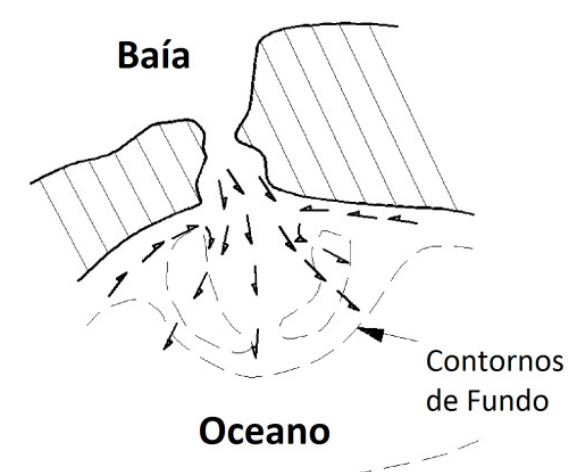

Correntes de Maré Vazante

Figura 9: Diagrama esquemático das correntes de maré enchente e vazante na porção marinha do canal. (Modificado de O'Brien, 1969; CERC, 2002).

Estudando a costa da Georgia, EUA, Oertel (1988) definiu um modelo simples para a morfologia do delta de maré vazante. Sua aplicação é possível na maior parte dos canais de maré, se levadas em conta as peculiaridades locais. A figura 11 ilustra tal modelo que conta com quatro situações, os vetores indicam o sentido das correntes predominantes, variando de predominância 
simples das correntes de deriva litorânea (a) até domínio das correntes de maré (d).

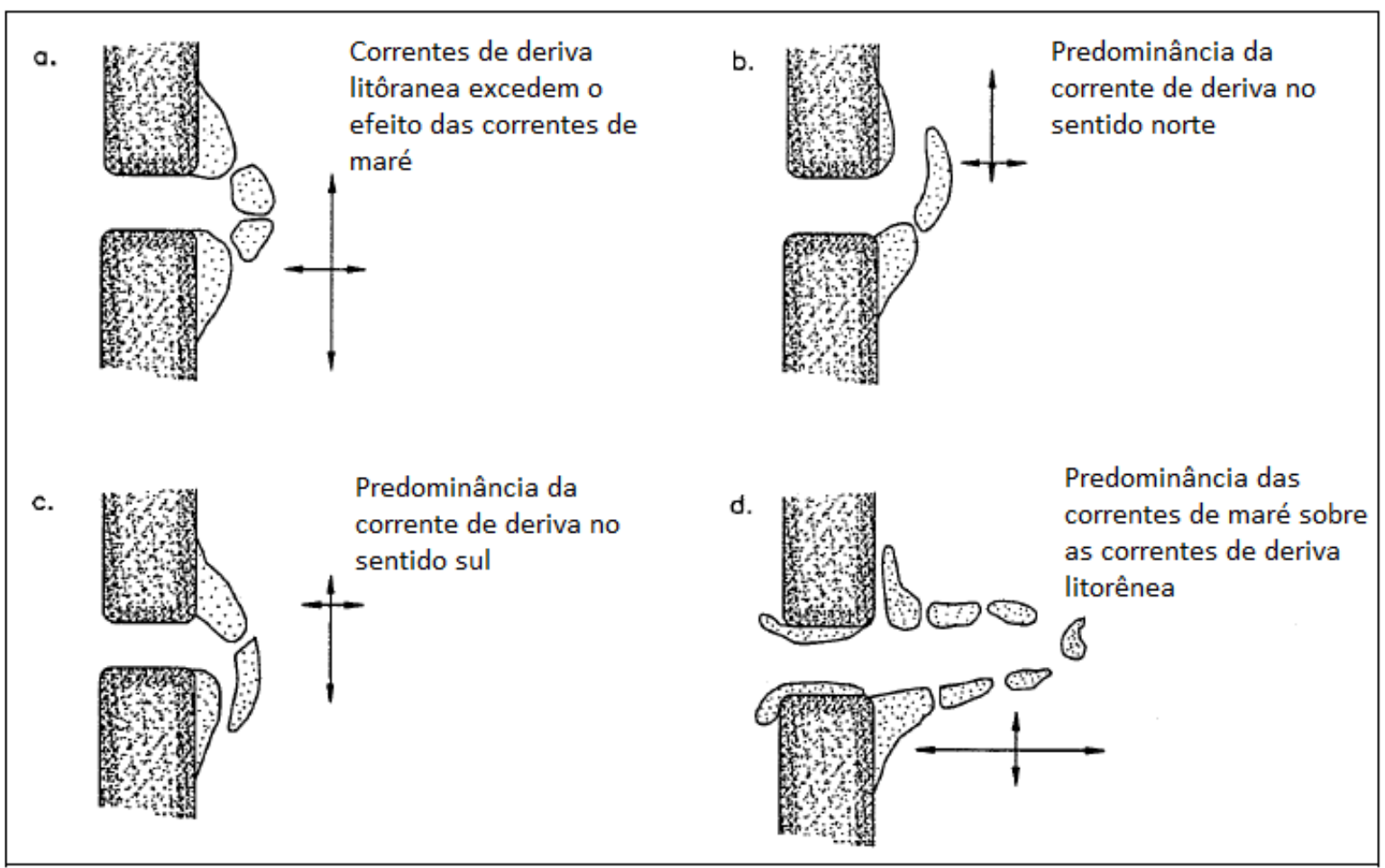

Figura 10: A morfologia de um delta de maré vazante indicando a influência relativa de ondas versus energia da maré bem como a direção dominante do transporte de sedimento paralelo à costa (Modificado de Oertel, 1988; CERC, 2002).

O prisma de maré é o produto entre a área do canal de maré e amplitude da maré, ou seja, o volume total de água que passa através da desembocadura pelo ciclo da maré (Pereira et al., 2010). Tal variável tem ralação direta com o tamanho da desembocadura (O'Brien, 1931, 1969 apud CERC, 2002) e o com volume do delta de maré vazante (Walton e Adams, 1976 apud CERC, 2002). 


\section{4 - Área de Estudo}

\section{1 - Aspectos Gerais}

No extremo sul do litoral paulista se encontra a planície costeira mais extensa do estado (figura 11), local onde se desenvolveu o chamado Complexo Estuarino Lagunar Cananéia-Iguape (Bonetti Filho \& Miranda, 1997). O Complexo é composto por ilhas (Cananéia, Comprida, Iguape e Cardoso), canais lagunares (Mar de Cananéia, Mar Pequeno, Mar de Cubatão e canal de Ararapira), rios de gamboa, desembocaduras (Barra de Icapara, Barra de Cananéia e Barra de Ararapira) e canais artificiais (Valo Grande e canal do Varadouro, sendo este uma conexão hidrográfica com o outro sistema semelhante, o Complexo de Paranaguá mais ao sul).

A região apresenta drenagem complexa, formada por muitos rios gambóas e riachos, sendo o mais importante o rio Ribeira de lguape, o rio de maior expressão do litoral paulista. A contribuição do Ribeira ao Complexo Cananéia-Iguape passou a existir a partir da abertura do canal do Valo Grande em 1841, no município de Iguape. No ano de 1978 o canal foi fechado artificialmente, porém intensas chuvas o reabriram em 1995 (Bonetti Filho \& Miranda, 1997). A abertura do canal, além de aumentar a introdução de água doce, acarretou modificações substanciais ao aporte sedimentar (principalmente das frações pelíticas) no Complexo Cananéia-Iguape causando consequências tanto para os processos ecológicos como para os processos sedimentares.

A ocupação humana está presente na região há muito tempo,

inicialmente habitada por povos indígenas e posteriormente pelos 
colonizadores europeus (Farinacceo, 2008). Contudo a região é considerada uma área de baixo impacto antrópico, contando com florestas de mata atlântica e bosques de manguezais bem conservados. Há pelo menos três unidades de conservação ambiental inseridas na área, sendo estas a Área de Proteção Ambiental (APA) de Ilha Comprida, a APA Cananéia-Iguape-Peruíbe e o Parque Estadual da llha do Cardoso.

Neste contexto se insere a llha Comprida, com cerca de $70 \mathrm{~km}$ de comprimento e largura entre 3 e $5 \mathrm{~km}$, e altitude raramente ultrapassando os 5 m (Suguio \& Martin 1978). A ilha é separada do continente pelo Mar de Cananéia e pelas Barras de Icapara, ao norte, e de Cananéia ao sul. A Barra de Cananéia é tradicionalmente utilizada nas atividades de navegação, sendo o principal acesso ao oceano do Complexo Cananéia-Iguapé. Porém é notória a periculosidade da área, associada principalmente a movimentação constante dos bancos de areia presentes em sua interface com o oceano. Nesta ilha está compreendido o município de Ilha Comprida

A ilha acompanha a orientação geral NE-SW da costa paulista, estando quase todo seu complexo praial exposto a ondas dos quadrantes SE, S, SE, E e NE. Sua constituição é amplamente dominada por sedimentos arenosos dispostos sob a forma de cordões litorâneos, com ocorrência de cordões de dunas.

Segundo Farinaceo (2008), desde a década de 1980 a ocupação humana cresce de forma acelerada no setor norte da ilha, onde se localiza a atual sede do município de llha Comprida. Ainda segundo este autor, nas áreas mais ao sul da ocorrem comunidades tradicionais, loteamentos para casas de veraneio, pousadas e estabelecimentos comerciais relacionados à atividade 
turística.

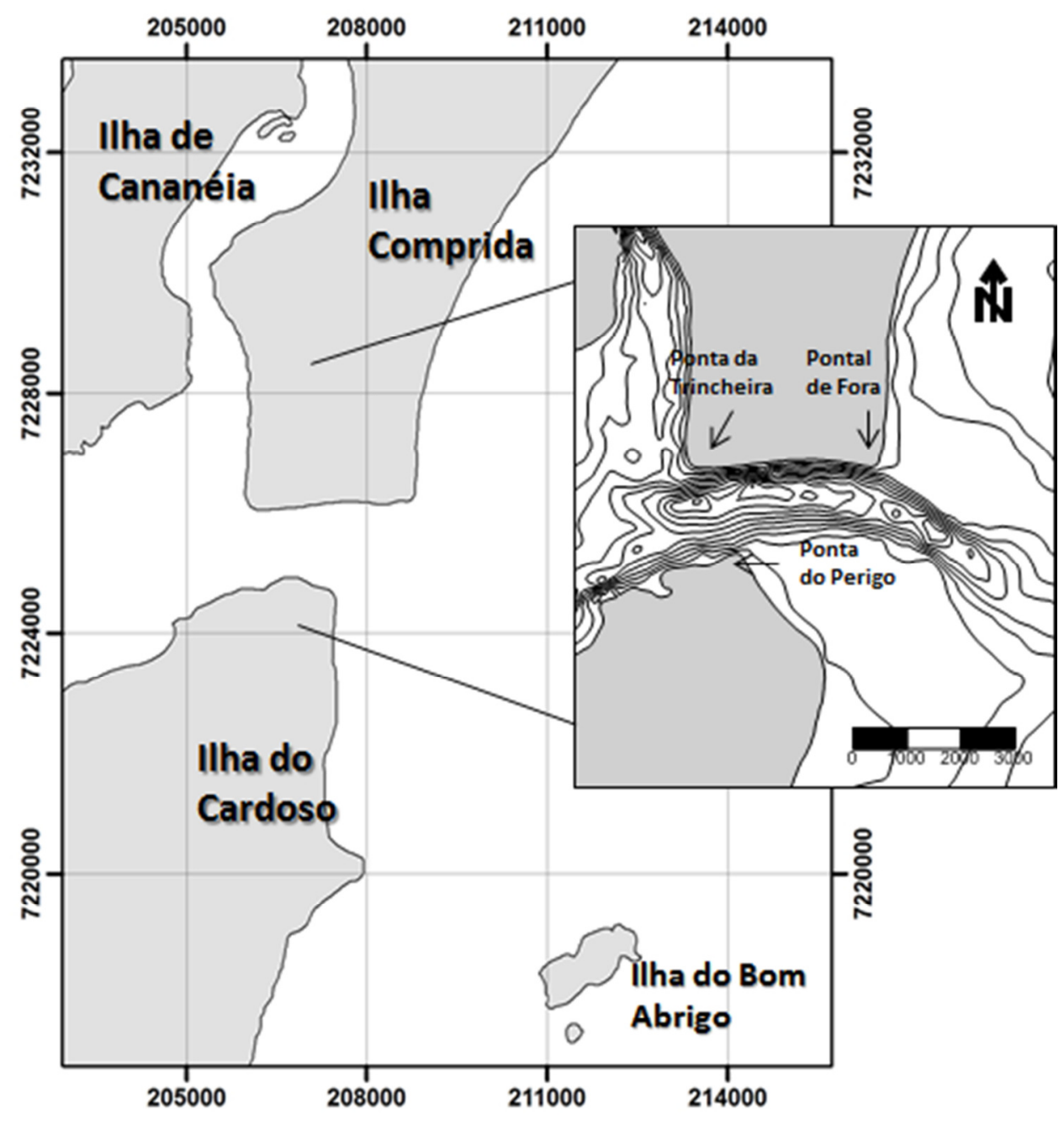

Figura 11: Localização de Ilha Comprida

\section{2 - Geologia e Geomorfologia da Planície Cananéia-Iguape}

O litoral do estado de São Paulo se encontra em um trecho da costa brasileira marcada pela presença de escarpas cristalinas, abrangendo desde 0 Cabo de Santa Marta (SC) até Cabo Frio (RJ) (Tessler \& Cazzoli y Goya, 2005). Essas escarpas formam o conjunto das serras do Mar-Mantiqueira, sua origem causa controvérsia entre vários autores.

Almeida e Carneiro (1998) consideram o relevo atual da Serra do Mar 
como resultado do recuo erosivo das principais falhas da borda da bacia de Santos. Já o estudo realizado por Zalan \& Oliveira (2005), atribui o relevo atual da Serra do Mar a um colapso gravitacional, precedido por um soerguimento intraplaca no Cretáceo superior, com formação de riftes paralelos à costa. Tal soerguimento foi marcado por eventos de magmatismo alcalino, que culminaram na formação de uma série de morros no litoral paulista.

De modo geral, o litoral paulista pode ser subdivido em função da variação da proximidade das escarpas cristalinas da linha de costa. Na porção Norte o Embasamento Cristalino aflora constantemente muito próximo as águas marinhas, configurando um litoral recortado com praias confinadas a pequenas baías. Na porção Sul o maciço rochoso normalmente se encontra a algumas de dezenas de quilômetros, configurando planícies costeiras mais desenvolvidas, apresentando praias mais expostas. Em um desses recuos da Serra do Mar se insere a região de Cananéia-Iguape.

A região é classificada como uma planície sedimentar costeira e apresenta um formato aproximadamente triangular limitado pelo afloramento do Embasamento Cristalino (Tessler, 1988). Tem um tamanho aproximado de 130 por 40 km, sendo os sues limites: o morro de Icapara a NE; a Ilha do Cardoso a SW e a serrania da cidade de Registro a N.

A planície Cananéia-Iguape esta muito ligada as flutuações do nível relativo do mar durante o Quaternário. Segundo a literatura estas oscilações produziram um sistema composto por três formações sedimentares na planície (Nascimento Jr, 2006; Karniol-Marquez, 2007; Guedes, 2009).

A Formação Pariquera-Açu ocupa o nível mais próximo ao embasamento cristalino aflorando na cidade homônima e em subsuperfície, 
abaixo da formação sotaposta (Formação Cananéia). É constituída de orto e paraconglomerados e de sedimentos argilosos e arenosos atribuídos a leques aluviais e depósitos fluviais e lacustres (Melo,1990). Segundo Guedes (2009) as evidências sobre sua idade são inconclusivas, havendo discordância entre diversos autores.

A Formação Cananéia foi inicialmente descrita por Suguio \& Petri (1973) como uma única sequência litológica. Posteriormente Suguio \& Martin (1978) aumentaram sua abrangência para mais duas sequências litológicas, localizadas sobrepostas a primeira. Atualmente a Formação é descrita como: (1) sedimentos síltico-argilosos (até 14 m de espessura); (2) areias siltosas (até $12 \mathrm{~m}$ de espessura) e (3) areias finas muitos bem selecionadas (de até $30 \mathrm{~m}$ de espessura). Os mesmos autores relacionam sua origem a um evento de flutuação do nível relativo do mar, nomeado por estes como Transgressão Cananéia. Através de datações $14 \mathrm{C}$ e correlação com corais da costa baiana, os autores obtiveram uma idade pleistocênica (cerca de 120000 anos A.P.).

A Formação llha Comprida foi informalmente designada como Formação Santos (Suguio \& Martin, 1978) por se referir a sedimentos geneticamente relacionados à Transgressão Santos e a regressão subsequente. A Formação é composta por areias marinhas finas e muito finas e sua distinção da Formação Cananéia se dá apenas por critérios cronológicos, não litográficos, sendo mais próximas de séries cronológicas distintas do que de formações, como apontado por Tessler (1988).

A llha Comprida é quase toda formada por sedimentos arenosos. A única exceção é o morro do Morrete, considerado um corpo satélite do morro de São João em Cananéia. Estes dois corpos são formados por rochas 
intrusivas alcalinas, de natureza sienítica, cortam o Complexo do Embasamento Cristalino e estão associados ao condicionamento tectônico do Arco de Ponta Grossa (Spinelli, 2003).

Suguio \& Martin (1978) descreveram a ilha como uma ilha-barreira, formada pelas contínuas variações do nível relativo do mar durante o Quaternário. Estes autores adotaram um modelo para explicar a evolução sedimentar da llha Comprida.

A primeira fase se iniciou em 5100 anos AP, no último máximo trangressivo (Trangressão Santos), quando somente um trecho da porção centro-sudeste se encontrava emerso, composto por sedimentos da Formação Cananéia. Em um segundo estágio em 3100 anos AP, com o recuo nível do mar, a porção sudeste da ilha, também composta por sedimentos da Formação Cananéia, foi adicionada a porção emersa e começou a apresentar crescimento longitudinal. Desse período até a fase atual a ilha foi marcada pelo crescimento longitudinal e alargamento concomitante.

Guedes (2009) estabeleceu outro modelo de evolução de llha Comprida baseado na análise de fotografias aéreas, parâmetros granulométricos, minerais pesados e datações por luminescência opticamente estimulada.

O autor definiu cinco fases distintas na evolução da ilha. A primeira corresponde a formação da barreira transgressiva em aproximadamente 6000 anos A.P., período de provável subida do nível do mar. Após essa fase inicial a ilha progradou até 5000 anos A.P., apresentando crescimento acelerado tanto transversalmente quanto longitudinalmente através da adição de cordões litorâneos. Entre 5000 e aproximadamente 1900 anos A.P. a ilha praticamente 
não apresentou engorda transversal e a taxa de crescimento longitudinal foi baixa $(5,2$ a $6,9 \mathrm{~m} / \mathrm{ano})$.

Com os morros próximos a Iguape bloqueando o crescimento longitudinal, a Ilha inteira passou por um período de intensa engorda transversal entre 1900 e aproximadamente 500 anos A.P. No período subsequente, entre 550 a 200 anos A.P. aproximadamente, as mudanças no regime ventos e ondas, associadas à Pequena Idade do Gelo, parecem ter favorecido a erosão e/ou estabilidade de toda linha de costa. Tal fato é ilustrado pela formação de cordões de dunas ao invés das habituais cristas praiais.

Dessa época até o presente a Ilha Comprida venceu o obstáculo do morro de Icapara e voltou a crescer longitudinalmente de forma acelerada (25 a $30 \mathrm{~m} / \mathrm{a})$, situação provavelmente provocada pela abertura do canal Valo Grande pela mão do homem, o que intensificou o molhe hidráulico da Barra de Icapara, aprisionando sedimentos na ponta da ilha. Provavelmente, as condições de vento continuaram intensas, visto que os cordões de dunas ainda se formam no centro-sul de Ilha Comprida, configurando segundo o autor uma situação de erosão transversal nessa região em oposição nas extremidades norte e sul.

\section{3 - Praia de Ilha Comprida}

Barcelos (1975) encontrou cinco subambientes deposicionais: eólicodunas, praial, marinho raso - cordões litorâneos, marinho raso - praial e mangue e reconheceu, também, que a deposição dos sedimentos na face marinha tem ocorrido predominantemente na direção NE. Esta hipótese 
apoiada por Tessler (1988) ao observar o padrão de crescimento dos cordões litorâneos, indicativo que provavelmente esse padrão de direção já era preponderante desde o máximo transgressivo holocênico.

Souza (1997), em estudo sobre as células de deriva litorânea e erosão para todo o estado de São Paulo, verificou que nas desembocaduras lagunares de Cananéia e Icapara ocorrem intensos processos deposicionais influenciados tanto pela ação marinha quanto pelas atividades flúvio-lagunares. A mesma autora sugeriu um padrão de células de deriva litorânea mais complexa, no qual, apesar do padrão predominante para NE, haveria duas células com uma zona de divergência na porção centro-sul.

Nascimento Jr. (2006), em seu estudo abordando a praia e as dunas frontais adjacentes à praia de Ilha Comprida, usa parâmetros estatísticos da distribuição granulométrica segundo a regra de McLaren \& Bowles (1985, apud Nascimento Jr., 2006), para confirmar o rumo predominante de deriva litorânea para NE com a presença de duas células de deriva litorânea distintas. $\mathrm{O}$ autor definiu duas células de deriva com rumos opostos, a primeira localizada na porção nordeste da ilha apresenta rumo de deriva NE e abrange $53 \mathrm{~km}$, enquanto a segunda está localizada no sudeste, abrange aproximadamente 10 $\mathrm{km}$ de extensão e possui rumo de deriva SW. Ainda segundo o autor existe uma zona de divergência entre as duas regiões, provável fonte de sedimentos, caracterizada por erosão costeira acentuada.

O mesmo padrão de deriva litorânea é encontrado por Guedes (2009) através da utilização da distribuição dos minerais pesados para inferir os processos de seleção hidrodinâmica no transporte sedimentar. Seus resultados ainda evidenciam a hipótese da semelhança entre os transportes sedimentares 
pretéritos e atuais na Ilha Comprida.

Karniol-Marquez (2007) estudou a morfodinâmica de um trecho localizado na porção sudoeste da ilha e monitorou também as condições meteorológicas a fim de gerar correlações com os processos deposicionais condicionantes. Seus resultados demonstraram uma praia erodida no inverno e acrescida no verão. Nas condições hidrodinâmicas observadas neste estudo o transporte transversal à praia se revelou mais atuante que o longitudinal.

Quanto à variação do estado morfodinâmicos da praia, a mesma autora encontrou dois estágios: praia dissipativa com a presença de cúspides em maio de 2005 e janeiro de 2006 e praia intermediária tipo banco e calha em agosto e novembro de 2005. Esses resultados coincidem com os encontrados por Nascimento Jr. (2006). O autor associa os primeiros $16 \mathrm{~km}$ no sentido SW-NE da ilha a predominância dos estágios morfodinâmicos de praia intermediário à dissipativo. Cabe ressaltar que nenhum dos trabalhos contou com medições dos parâmetros da classificação morfológica de Wright \& Short (1983, 1985).

\section{4 - Desembocadura de Cananéia}

A Desembocadura de Cananéia, localizada a sudeste da cidade de mesmo nome, separa as ilhas Comprida e do Cardoso, sendo o maior canal de ligação entre as águas continentais e o oceano do Sistema Estuarino-lagunar Cananéia-Iguape. Popularmente denominada de Barra de Cananéia, a desembocadura recebe as águas provindas do Mar de Cubatão que desagua na chamada Baía do Trampandé, onde encontra o fluxo d'água advindo do Mar de Cananéia.

A grande distância entre a Desembocadura de Cananéia e o Rio 
Ribeira de Iguape, limita a influência deste grande rio nos processos vigentes na desembocadura. A principal influência fluvial da região da desembocadura vem de uma bacia de drenagem com cerca $1.340 \mathrm{Km}^{2}$, composta pelos rios Taquari, Das Minas, Mandira e Itapitangui (Myshima et al., 1985).

As múltiplas fontes de aporte fluvial tornam complexa a determinação precisa do aporte total de água doce na Desembocadura de Cananéia, sendo os resultados encontrados na literatura conflitantes. Um estudo executado pelo DAEE em 1987 apresenta um valor $3 \mathrm{~m}^{3} \mathrm{~s}^{-1}$ para média de vazão anual para a bacia próxima a Cananéia, enquanto GEOBRÁS (1966) apresenta em valor de $50 \mathrm{~m}^{3} \mathrm{~s}^{-1}$, Boneti Filho \& Miranda (1997) apresentam $43 \mathrm{~m}^{3} \mathrm{~s}^{-1}$ e Bergamo (2000) um valor de $47,24 \mathrm{~m}^{3} \mathrm{~s}^{-1}$.

A desembocadura de Cananéia é o principal meio para trocas de águas entre o ambiente estuarino e marinho da região sul do complexo estuarinolagunar. Quando a onda de maré enchente penetra no sistema, ocorre uma divisão do fluxo com um dos ramos se propagando pelo canal do Mar de Cubatão, enquanto o outro ramo se propaga, rumo a NE, pelo canal do Mar de Cananéia (Tessler \& Souza, 1998). Devido a contribuição do aporte de água fluvial a maré vazante apresenta menor duração e correntes de fundo mais intensas do que a maré enchente, 0,7 e $0,6 \mathrm{~m} / \mathrm{s}$ respectivamente, enquanto na superfície são comumente registradas velocidades acima de $1 \mathrm{~m} / \mathrm{s}$ (Myao, 1977).

Bergamo (2000) executou um estudo detalhado da hidrografia e circulação estuarina da região da Desembocadura de Cananéia. Os seus resultados indicam uma predominância das trocas de água no sentido do Mar de Cananéia, em detrimento da Baía do Trapandé. O autor aponta uma 
defasagem de cerca de 1 hora na propagação da onda de maré entre a desembocadura e a estação maregráfica na base do IOUSP, além de classificar os processos hidrodinâmicos da área com base em teorias da circulação estuarina.

A área onde se localiza a Desembocadura de Cananéia é listada como a porção mais antiga de Ilha Comprida por diversos autores (Suguio \& Martin, 1978; Guedes, 2009), fato explicado pela presença dos maciços alcalinos do Morro de São João em Cananéia e do Morrete em Ilha Comprida, configurando esta região como um alto estrutural propício ao acumulo de sedimentos.

A região da Desembocadura de Cananéia é conhecida como uma área de risco navegação devido a grande dinâmica de bancos de areia localizados em frente do canal principal e nas proximidades de suas margens. Tal fato fez com a desembocadura fosse monitorada desde o período da colonização portuguesa.

Os diversos levantamentos batimétricos realizados; como o da Diretoria de Hidrografia e Navegação do Ministério da Marinha (DHN - MM), do Laboratoire Nationale d'Hydraulique Chatou/Departamento de Águas e Energia Elétrica do Estado de São Paulo (DAEE - SP,1956, apud Suguio \& Tessler, 1983) e o realizado por Paolo \& Mahiques (2008); demonstram a presença dos citados bancos e também a manutenção das profundidades do canal central em torno dos $20 \mathrm{~m}$ (Tessler et al., 1990).

A manutenção dessas profundidades é observada devido a uma depressão no embasamento rochoso que propícia à intensificação das correntes de maré. Tal depressão é relacionada ao afogamento de um paleovale na transgressão holocênica segundo Suguio \& Tessler (1983). O 
estudo realizado pela GEOBRÁS (1966) indica um abatimento estrutural. Qual quer seja sua origem essa situação indica a ausência de trocas significativas de sedimentos entre os ambientes marinho e estuarino ao longo dos últimos 70 anos (Tessler et al, 1990).

Os processos físicos atuantes e a dinâmica sedimentar da região da Desembocadura de Cananéia vêm sendo estudados desde a metade do século passado. Besnard (1950) associou observações da ação das ondas e das correntes marinhas com as feições morfológicas para desenvolver um modelo evolutivo do complexo Estuarino-Lagunar de Cananéia-Iguape, chegando até mesmo a apresentar hipóteses para situações futuras. Sadowsky $(1952,1954)$ seguiu a mesma linha de estudo para explicar episódios de mudança sedimentar ocorridos durante dois anos de observações em campo da região.

Os dois autores indicam uma forte atividade nos bancos arenosos adjacentes ao canal central e indicam uma tendência de erosão na margem leste da Ilha do Cardoso, deixando a margem do canal de Ilha Comprida mais exposta ao embate das ondas e consequentemente ocasionando a erosão desta e o deslocamento do canal para a direção Norte. Sadowsky (1954) aponta a formação de uma "nova ilha" em frente à margem leste da llha do Cardoso.

Em 1971, Petri \& Suguio usaram fotos aéreas e trabalhos de campo para estudar a configuração das margens da Desembocadura de Cananéia. Os resultados obtidos apontaram para uma grande dinâmica sedimentar, com uma tendência geral de acresção para a área, mas com episódios de erosão associados às condições de ventos e ondas ideais. Suguio \& Tessler (1983) comparam tais resultados com as fotografias aéreas de 1973, não encontrando 
alterações significativas na dinâmica estabelecida. Os autores também destacam o crescimento de bancos arenosos submersos dispostos quase que paralelamente a orientação do canal, associando estas feições à ação conjunta das correntes de maré vazante e das correntes resultantes da ação das ondas incidentes.

Tessler et al. (1990) interpretam os mecanismos hidrodinâmicos que condicionaram a evolução geomorfológica da Desembocadura de Cananéia com base na análise das linhas de costas extraídas a partir de fotos aéreas de 1954, 1981 e dos resultados obtidos em um estudo usando fotos aéreas de 1952, 1962 e 1969 realizado pelo Centro Tecnológico de Hidráulica (CTH /USP - 1973).

Os resultados expõem uma tendência de erosão do setor norte da llha do Cardoso e na porção da llha Comprida voltada a desembocadura, enquanto a região leste da Ilha do Cardoso apresenta acresção. Os autores atribuem tal condição a variação dos trens de ondas incidentes devido à passagem de sistemas frontais provindos S e SE, resultando em correntes de deriva litorânea que transportam sedimentos na direção NE.

Os bancos formados em frente ao canal principal ocorreriam devido a perda de competência das correntes de deriva litorânea em face a ação das correntes de maré vazante. Posteriormente esses sedimentos seriam novamente carregados para NE pela ação da deriva litorânea, sendo depositados ao longo de toda praia de llha Comprida. A esses sedimentos também se somam os sedimentos erodidos da margem da desembocadura, os quais em um primeiro momento contribuem para o crescimento da ponta sul da Ilha Comprida. 
A fim de se caracterizar a dinâmica sedimentar do Complexo EstuarinoLagunar de Cananéia-Iguapé, Tessler \& Souza (1998) se valeram de análises de cartas náuticas e levantamentos batimétricos, além de dados sedimentares, correntometrias de fundo e superfície e levantamentos geofísicos. Os autores relacionam os sedimentos e as feições encontradas com as características hidrodinâmicas dos canais internos do sistema. Os resultados revelam que maiores valores para velocidades de corrente se encontram na Desembocadura de Cananéia durante a maré vazante $(1,2 \mathrm{~m} / \mathrm{s})$, além de demonstrarem que as maiores diferenças nos perfis batimétricos ocorrem nesta região.

Paolo \& Mahiques (2008) utilizaram levantamentos batimétricos e métodos geofísicos para estudar as feições de fundo presentes no canal da desembocadura de Cananéia e nas áreas próximas, localizadas no Mar de Cananéia e na Baía de Trapandé. Seus resultados revelaram a presença de megaondulações nas áreas mais internas e ondas de areia na porção mais externa, próxima ao mar aberto.

Através da interpretação das feições e comparação com os resultados obtidos por Tessler \& Souza (1998), os autores estabeleceram um modelo de transporte para a região, apontando uma diminuição da intensidade do fluxo em direção ao interior do estuário. Outro resultado interessante é a ocorrência concomitante de correntes de fundo com sentido inverso, tanto durante a maré vazante quanto na maré enchente. As figuras 12 e 13 expõem os resultados alcançados pelos autores. 


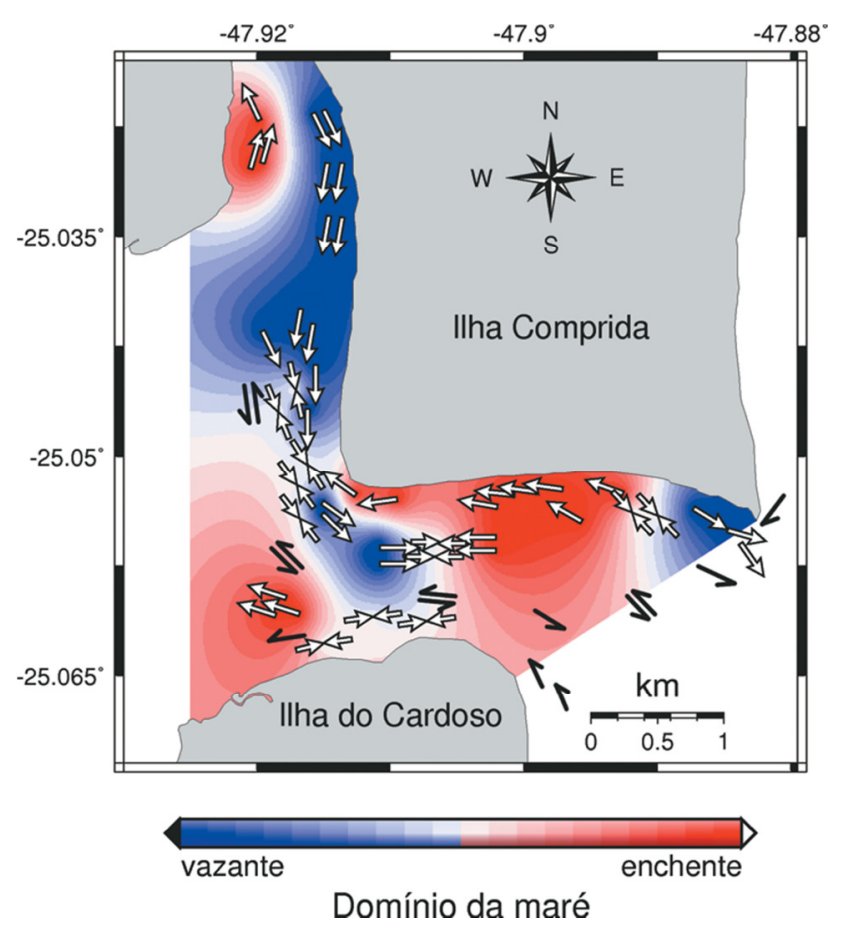

Figura 12: Escala de cor representando os domínios dos fluxos de maré sobre o fundo inferido a partir da morfologia das feições (setas brancas) e estimado por Tessler \& Souza (1998) (setas escuras). Extraído de Paolo \& Mahiques (2008)

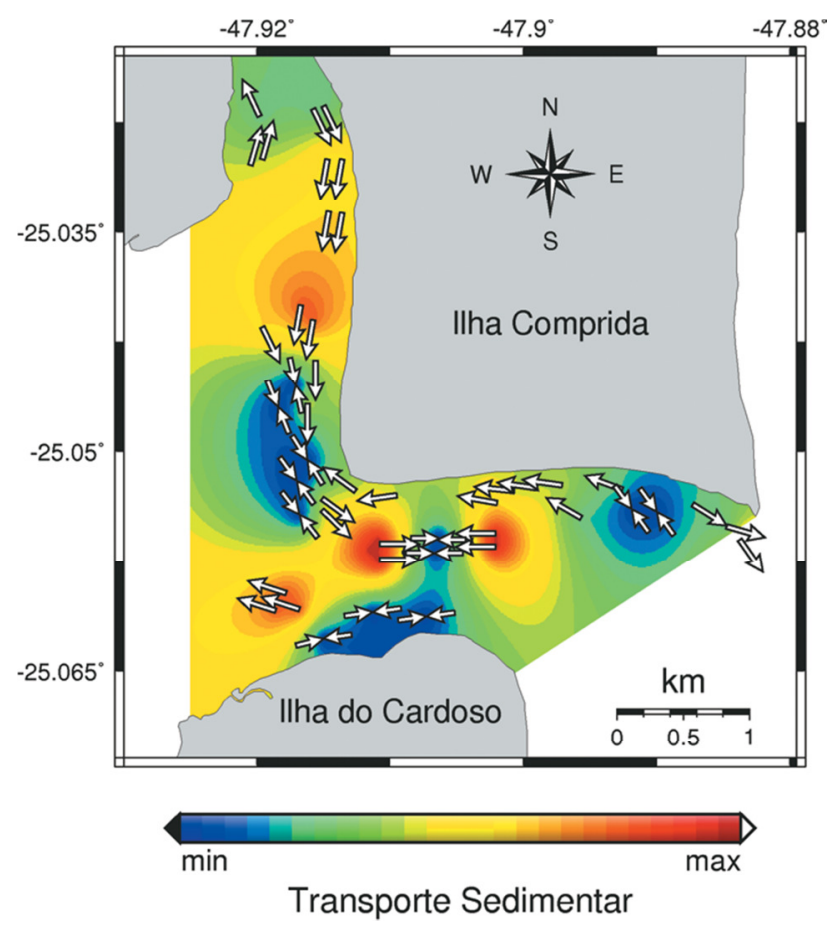

Figura 13: Resultante do transporte, onde cada vetor representa a direção e o sentido preferencial da circulação de fundo em cima de cada feição identificada. Escala de cor representando qualitativamente a intensidade relativa deste transporte, onde as feições simétricas representam transporte mínimo. Extraído de Paolo \& Mahiques (2008). 
Em posse de diversos tipos de dados, como cobertura sedimentar, feições de fundo, conteúdo de matéria orgânica, linhas de costa obtidas por fotos aéreas e imagens de satélite e resultados de modelos computacionais, Conti et al.(2012) utilizaram Sistemas de Informações Geográficas (SIG) para integrar e analisar essas informações em busca de um cenário abrangente dos processos sedimentológicos e morfológicos atuantes no Sistema EstuarinoLagunar de Cananéia-Iguape. Através da análise de fotos e imagens de satélite os autores identificaram as mudanças nas linhas de costa das margens do canal da Desembocadura de Cananéia e correlacioná-las a padrões de sedimentação obtidos através da aplicação de diversos modelos, baseados tanto nos processos hidrodinâmicos, quanto nas características, distribuição e morfologia dos sedimentos de fundo.

Na margem de llha Comprida foi identificada a ação mais intensa das correntes de maré devido a batimetria local ser mais íngreme e apresentar as maiores profundidades. Os autores ainda destacam a ação da passagem de frentes frias na sedimentação da porção mais próxima ao mar, ocorrendo uma variação de mais de 500 m na posição da linha de costa entre 1962 e 2006, alternado entre fases deposicionais e fases erosivas. Na margem da llha do Cardoso foram descritos processos erosivos da porção marinha e deposicionais na margem do canal. Os autores expõem uma menor efetividade das correntes de marés nesse processo, relacionando a tendência erosiva na porção marinha a ação das ondas, e ainda demonstrado uma mudança no sentido de orientação dos cordões arenosos mais atuais em relação aos cordões litorâneos holocênicos antigos, respectivamente a NE-SW e N-S. 


\section{5 - Fatores Oceanográficos e Meteorológicos}

Existem dois principais sistemas atmosféricos responsáveis pela geração das ondas que atingem a costa brasileira: o Anticiclone Tropical Atlântico (ATA) e os Ciclones Extratropicais. As ondas geradas pelo ATA afetam praticamente toda a costa brasileira, enquanto as geradas pelos ciclones extratropicais afetam com maior intensidade as costas sul e sudeste e ocasionalmente a costa sul da região Nordeste.

O ATA é um anticiclone semifixo localizado aproximadamente a $30^{\circ}$ de latitude do Atlântico Sul e está relacionado ao transporte de calor entre as médias latitudes e o equador, sendo o responsável pelos ventos alísios de SE que atingem principalmente o litoral nordeste e norte (Karniol-Marquez, 2007). Devido à migração sazonal desse sistema, durante o verão a influência dos ventos alísios chega até acima dos $10^{\circ} \mathrm{S}$ de SE e E e desta porção até $40^{\circ} \mathrm{S}$, de NE e NW. No inverno geralmente ação desses ventos não ultrapassa os $20^{\circ}$ S.

As ondas geradas por esse sistema chegam a costa paulista do quadrante NE e apresentam período médio entre 8 e $12 \mathrm{~s}$ e altura variando entre 1 e 1,5 m. Normalmente, essas ondas estão associadas a condições climáticas de tempo bom e ocasionam o surgimento de uma corrente de deriva litorânea com sentido SW (Tessler, 1988). Por serem menos energéticas, causam um transporte longitudinal de sedimentos menos intenso do que 0 produzido pelas ondas geradas pelos ciclones extratropicais.

Os ciclones extratropicais estão ligados às trocas de calor entre a zona 
tropical e os polos. São considerados os fenômenos dominantes do clima na escala sinótica em médias e altas latitudes e normalmente estão associados a fortes ventos e chuvas (Lim \& Simmonds, 2007).

Na região do Atlântico Sul Gan \& Rao (1991) identificaram duas áreas de formação ciclogênica, uma localizada na Argentina (42,5 $S$ e $62,5^{\circ}$ W) explicada pela instabilidade baroclínica local dos ventos de oeste e outra no Uruguai (nas proximidades de $31,5^{\circ} \mathrm{S}$ e $55^{\circ} \mathrm{W}$ ) associada a anomalia baroclínica provocada pela presença da Cordilheira dos Andes. A área localizada na Argentina exibiu o máximo de formação ciclones no verão, enquanto a região no Uruguai apresentou máximos de atividade durante o inverno.

Hoskins \& Hodges (2005) e Reboita (2008) apontam outra área de ciclogênese no América do Sul, localizada na zona tropical do Atlântico Sul (entre $20^{\circ} \mathrm{S}$ e $35^{\circ} \mathrm{S}$ ), na costa das regiões Sul e Sudeste do Brasil. A zona apresenta maior atividade ciclogênica durante o verão, e está ligada a sistemas atmosféricos provindos do Oceano Pacífico que acabam por serem intensificados pela transferência de calor latente entre as águas costeiras quentes e a atmosfera.

Gan \& Rao (1991) ainda abordaram a frequência de ocorrência dos ciclones extratropicais na América do Sul em um período de 10 anos, obtendo 305 ocorrências no inverno, 302 no outono, 268 na primavera e 207 no verão. A maior frequência mensal foi identificada mês de maio, totalizando 134 ocorrências, enquanto o mês que exibiu a menor frequência foi dezembro com 71 casos. Além da sazonalidade, os ciclones extratropicais são fortemente influenciados pela variação interanual do sistema El Niño/ La Niña. Durante os 
anos de aquecimento anormal das águas superficiais do Oceano Pacífico (El Niño) ocorre um incremento da frequência dos anticiclones extratropicais, e durante os anos de resfriamento anormal (La Ninã) acontece uma diminuição de ciclogênese no Atlântico Sul.

Alves (2006) se utilizou de simulações numéricas para caracterizar as ondas geradas pelo vento em diferentes áreas do globo durante um período de 30 anos (1971-2000). Seus resultados demonstraram uma média de 147 tempestades extratropicais por ano para o Atlântico Sul, com uma duração média de 3,6 dias.

Usualmente os ciclones extratropicais que ocorrem na América do Sul de deslocam para Sul e Leste, duram em média 3 dias, e presentam velocidade média de $9 \mathrm{~ms}^{-1}$ (Reboita, 2008), porém suas velocidades e trajetórias podem variar com as condições climáticas. Reboita et al. (2009) descrevem um sistema que apresentou comportamento semi-estacionário na costa do Rio Grande do Sul, ou seja, deslocou-se com velocidades muito abaixo das médias históricas. Os resultados demonstraram que os ciclones com esse tipo de comportamento acabam por causar chuvas e ondas mais intensas e muitas vezes marés meteorológicas.

Estudando os efeitos dos ciclones extratropicais nas praias do Rio Grande do Sul, Parise et al. (2009) encontram três padrões de migração dos ciclones extratropicais associados a marés de tempestade:

- Padrão I: Ciclogênese no Sul da Argentina e migração para leste entre $47,5^{\circ} \mathrm{S}$ e $57,5^{\circ} \mathrm{S}$;

- Padrão II: Ciclogênese na costa sul do Uruguai com deslocamento no rumo leste entre $28^{\circ} \mathrm{S}$ e $43^{\circ} \mathrm{S}$; 
- Padrão III: Ciclogênese na costa sul do Uruguai com deslocamento para sudeste entre $32^{\circ} \mathrm{S}$ e $57,5^{\circ} \mathrm{S}$.

Os ciclones extratropicais estão associados ao encontro de duas massas de ar de diferentes temperaturas, uma fria formada nas regiões polares, e uma mais quente advinda da zona tropical. Durante o processo a massa de ar frio forma uma cunha que desloca o ar quente para níveis mais altos da atmosfera, configurando uma "frente fria" que avança sobre a massa de ar quente (Reboita, 2008).

Durante a migração das frentes frias são produzidas ondas em três situações distintas, provindas de direções distintas. A primeira situação é a préfrontal e produz ondas da direção S e SE; a segunda é chamada de frontal e produz ondas de E; a terceira é a pós-frontal e produz ondas de NE. As ondas associadas aos ciclones extratropicais são mais energéticas que as produzidas pelo ATA, apresentando período médio entre 6 e 9 s e altura média maior que $2 \mathrm{~m}$. O sentido da corrente de deriva litorânea produzida varia com a passagem do sistema, sob condições pré-frontais o sentido predominante é $\mathrm{NE}$, na condição frontal o sentido pode ser tanto NE quanto SW e sob condições pósfrontais o sentido é SW (Ponçano et. al., 1999).

Cabe ressaltar que os sentidos da corrente de deriva litorânea estão ligados também à orientação de cada sistema praial, sendo os sentidos aqui expostos referentes à orientação geral do litoral sudeste/sul brasileiro (NE-SW). O litoral sul de São Paulo se encontra em uma área caracterizada por regime de micro maré semi diurna, ou seja, varia menos de $2 \mathrm{~m}$ e seus picos ocorrem duas vezes por dia. Segundo Mesquita \& Harari (1983) a amplitude média de maré, medida na estação maregráfica de Cananéia, varia 1,2 m na 
sizígia 0,25 na quadratura.

\section{5 - Material e Métodos}

\section{1- Dados Topográficos}

\subsubsection{Coletas de Campo}

Foram realizadas nove saídas a campo para execução de levantamentos topográficos e coleta de sedimentos durante o período entre maio de 2011 e fevereiro de 2012, sendo a primeira saída considerada preparatória para definição dos setores de amostragem, apresentados na figura 14.

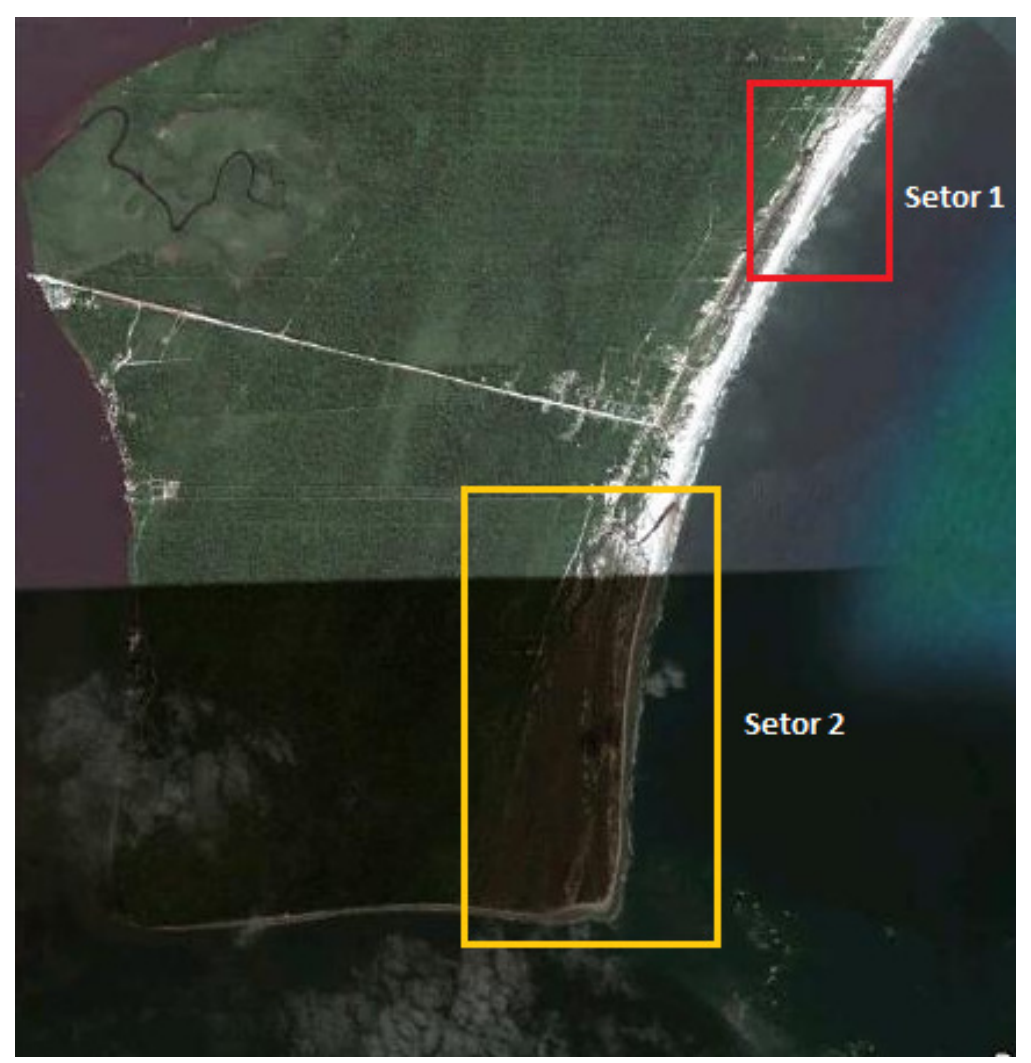

Figura 14: Localização dos setores amostrados

Ao Setor 2, localizado próximo a Desembocadura de Cananéia foi o 
principal foco das atividades, já o setor mais ao norte, denominado Setor 1 por uma questão geográfica, foi tratado como uma "área controle" por estar livre da influência dos processos sedimentares da desembocadura de Cananéia e também por estar distante da llha do Bom Abrigo, localizada a sudeste da llha Comprida. A presença da ilhado Bom Abrigo contribui para a dinâmica estabelecida na Desembocadura de Cananéia por criar um efeito de proteção natural da região contra as ondas incidentes dos setores S e SE.

O Setor 2 foi subdividido em duas áreas devido a sua grande extensão e por englobar ambientes morfodinamicamente distintos, os quais estão expressos na figura 15. As áreas são:

- Área Leste - Compreende a porção com orientação SW/NE em relação ao oceano. Encontra-se mais vulnerável a ação das ondas e provavelmente sofre menos influência da desembocadura de Cananéia. Apresenta um rio em sua parte norte, próximo a quiosques instalados no pós-praia. Justamente devido a essa proximidades o curso deste rio foi desviado de modo afasta-lo dos estabelecimentos comerciais;

- Área Sul - compreende a porção com orientação E/W em relação ao oceano, localizada canal da Desembocadura de Cananéia. Apresenta uma faixa de areia mais estreita e maior gradiente de inclinação. Está sujeita aos processos relacionados ao canal de maré. 


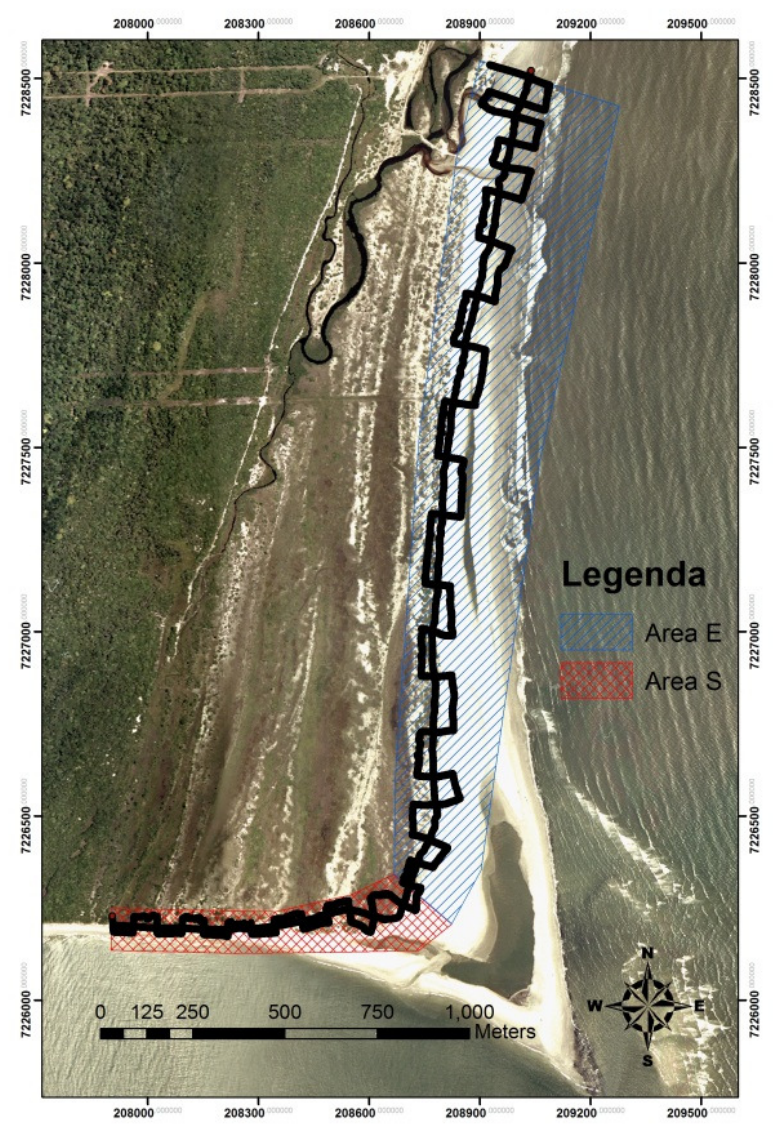

Figura 15: Áreas Leste e Sul do Setor 2 e o percurso do levantamento realizado no dia 21/11/2011.

As saídas a campo aconteceram preferencialmente no período da maré de sizígia, na lua nova, quando os efeitos da passagem de sistemas frontais são fortalecidos pelo maior nível d'água e também com o intuito de se aproveitar a maior área possível de praia emersa.

A duração das saídas a campo variou conforme a disponibilidade de equipamentos, pessoal e vagas na Base de Pesquisa do IOUSP "Dr. João de Paiva Carvalho", situada na cidade de Cananéia, além de condições meteorológicas favoráveis.

Os levantamentos foram realizados com o aparelho DGPS da marca Trimble, receptor modelo R3 e antena A3, utilizando-se a configuração PPK (Pos Processed Kinematic) do aparelho, na qual os dados são processados 
posteriormente em laboratório. Como referencial para processamento adotouse a estação fixa da Rede Brasileira de Monitoramento Contínuo (RBMC) do IBGE, localizada na Base de Pesquisas do IOUSP em Cananéia. Os dados aquisitados são disponibilizados pelo IBGE periodicamente no site: http://www.ibge.gov.br/home/geociencias/geodesia/rbmc/rbmc.shtm?c=7.

Os dados foram coletados por meio de um caminhamento contínuo, tentando produzir uma malha amostral que englobasse a maior área do prisma praial em face da duração da bateria do aparelho e da variação de maré. A forma que mais se adequou foi a de perfis transversais separados por distâncias entre 50 e 150 m (condicionadas em função das variações morfológicas da praia) cortados por uma linha continua passando aproximadamente na metade do pós-praia, como demonstrado nas figuras $16 \mathrm{e}$ 17. Os perfis transversais variaram entre o início da vegetação costeira e a máxima profundidade onde se pode caminhar com segurança com 0 equipamento (cerca de $40 \mathrm{~cm}$ ), dependendo da maré.

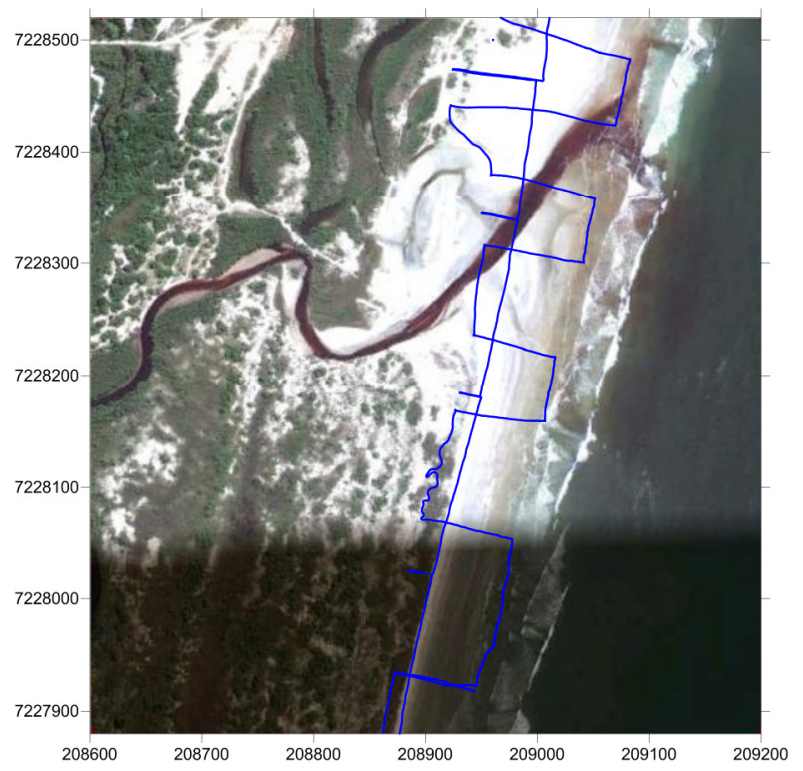

Figura 16: Caminhamento realizado dia 03/06/11. 


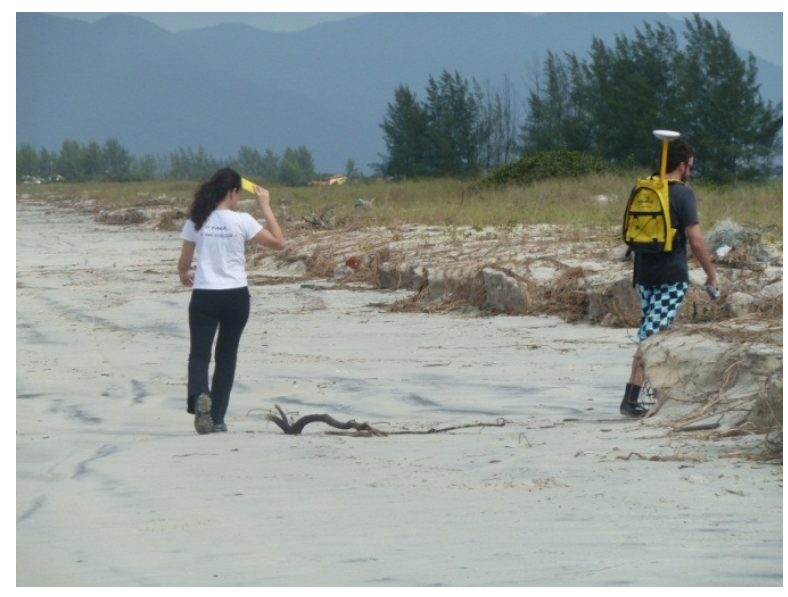

Figura 17: Caminhamento no limite entre face praial e vegetação.

Os levantamentos foram efetuados através de percursos livres, ou seja, sem a fixação de perfis obrigatórios durante os caminhamentos. Tal escolha é baseada na grande extensão da área de estudo, na grande densidade de pontos obtidos por levantamento e pelas características dissipativas da praia de Ilha Comprida.

\subsection{2 - Processamento em Laboratório}

Os dados foram processados em laboratório no programa Trimble Business Center (TBC), que corrige os dados coletados pela estação móvel com base nas informações adquiridas pela estação de referência fixa. As coordenadas obtidas apresentaram um erro máximo de $0,10 \mathrm{~cm}$ na vertical e $0,5 \mathrm{~cm}$ na horizontal. Cabe ressaltar que o erro presente nos dados é sujeito a variação das condições climáticas, que limitam a quantidade de satélites encontrados pelos receptores, muitas vezes inviabilizando a coleta de dados.

Foi utilizado o programa MAPGEO2010 do IBGE para referenciar as elevações obtidas ao modelo de geoide adotado no Brasil. Os arquivos XYZ gerados no TBC e corrigidos pelo MAPGEO2010 foram interpolados para gerar grids de modelos digital de terreno (MDT) no programa Global Mapper 11. 
O método interpolador que melhor se adaptou aos dados foi a Triangulação com Interpolação Linear, pois este é um interpolador exato, ou seja, os valores dos dados coletados são honrados no MDT, apresenta rápido desempenho computacional e é comumente utilizado para dados topográficos (Landim, 2000). Após a confecção de MDTs para cada dia de levantamento, estes foram subtraídos uns dos outros para obter-se as diferenças de elevação entre eles, resultando em novos MDTs.

Com base na discussão sobre a aplicação do DGPS para obtenção de MDTs apresentada em Baptista et al.(2008) e tendo em vista as tolerâncias utilizadas no processamento de dados no programa TBC, decidiu-se adotar um erro de $15 \mathrm{~cm}$ na vertical e $10 \mathrm{~cm}$ na horizontal para os MDTs. Deve se ressaltar que a maioria dos dados apresentou erros na casa dos $2 \mathrm{~cm}$ na vertical e $1 \mathrm{~cm}$ na horizontal. Contudo, para minimizar a perda de dados optouse em utilizar a já referida tolerância.

Os MDTs resultantes foram tratados no programa SURFER ${ }^{\circledR} 9$ (Golden Softwares Inc.) e utilizados para obtenção de perfis praias, com espaçamento de cerca 200 metros. Finalmente foram confeccionados mapas para uma melhor compreensão, contando com sobreposições dos perfis produzidos.

No cálculo do volume foi adotada a máxima área abrangida em todos os levantamentos, com a consequente produção de novos MDTs. Os cálculos foram efetuados no programa SURFER ${ }^{\circledR} 9$, utilizando-se os três métodos padrões oferecidos pelo software: Trapezoidal Rule, Simpson's Rule, Simpson's 3/8 Rule (Press et al., 1988 apud SURFER 9 User Guide), sendo adotado como resultado para o volume líquido a média entre o resultado dos três métodos, e para o volume total a soma entre o volume positivo e negativo 
fornecidos pelo software.

\section{2 - Coleta e Análise de Sedimentos}

Durante a execução dos caminhamentos para obtenção dos dados topográficos procedeu-se a coleta mensal de sedimentos nos dois setores estudados, totalizando 4 amostras no Setor 1 e 12 amostras no Setor 2. Os pontos foram definidos com base no traçado do percurso dos caminhamentos, a partir do ponto inicial, locado no primeiro perfil transversal. As amostras eram coletadas a cada dois perfis transversais, estando sempre situados na zona de espraiamento. A figura 18 demonstra os pontos se coleta de sedimentos em ambos os setores.

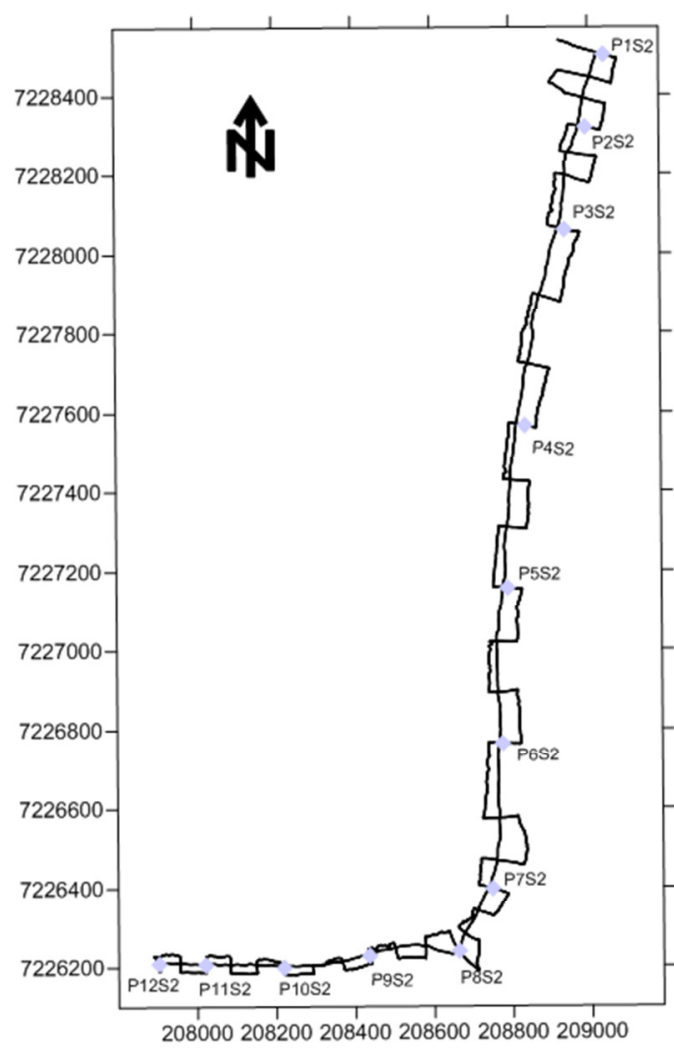

A

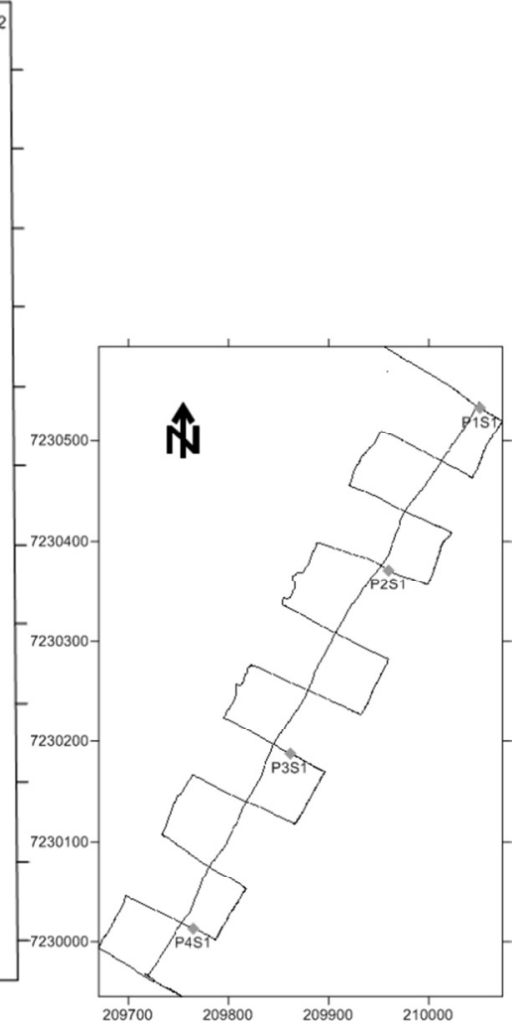

B

Figura 18: Posição dos pontos de amostragens de sedimento. A: Setor 2; B: Setor 1. 
As amostras foram submetidas a lavagem e depois expostas a ação de $\mathrm{HCl} 10 \%$ por pelo menos um dia a fim de se eliminar as partículas de carbonato de cálcio. Posteriormente, se aplicou o método descrito em Suguio (1973), no qual se obtém os volumes das diferentes frações granulométricas do material terrígeno de interesse, no caso grãos de areia, por meio do peneiramento mecânico simples.

Os resultados obtidos foram utilizados para alimentar o software GRANULO V.1 - BORLAND inc. (1983), a fim de se determinar os parâmetros de Folk \& Ward (1957). Este software calcula os parâmetros automaticamente apenas com a entrada dos dados do peso das frações granulométricas peneiradas

\section{3 - Análise de Linhas Costa Pretéritas}

O objetivo inicial do presente estudo era aplicar a metodologia proposta por Ferreira et al. (2006) para projeção de linhas costa futuras na porção da área de estudo sujeita principalmente a ação erosiva. No entanto, no decorrer das análises das fotografias aéreas e imagens de satélite ficou claro a importância dos processos sedimentares ligados a ação das correntes de maré na porção em processo de erosão na região de interesse. Tendo se em vista que a metodologia em questão não leva em consideração tais processos, decidiu-se em não aplica-la.

A metodologia proposta por Ferreira et.al.(2006) considera como pior cenário futuro para a linha de costa de áreas em progradação a própria configuração atual nestes sistemas, tornando-se irrelevante a determinação de 
linhas de costa futuras na área estudada em face dos objetivos desta dissertação.

Optou-se então apenas pela determinação da taxa de variação da linha de costa anuais a fim e se ter uma quantificação dos processos de erosão e acresção vigentes na área da desembocadura de Cananéia para comparação com estudos posteriores. Para tanto se aplicou a extensão Digital Shoreline Analyses System 4.0 (DSAS) (Thieler et al.,2005), do Sistema de Informação Geográfica (SIG) $\operatorname{ArcGIS}^{\circledR} 9.3$ da ESRI softwares. Inicialmente foram adquiridas fotografias aéreas dos anos 1962, 1973, 1981 e 2001, cedidas pelo Msc. Carlos Alberto Araújo, e imagens de satélite de 2009 a partir do programa Google Earth ${ }^{\circledR}$. Todos as imagens foram georreferenciadas ao datum WGS84 usando o SIG ArcGIS ${ }^{\circledR} 9.3$ a partir da fotografia de 2001 já georreferenciada pelo INPE - Instituto Nacional de Pesquisas Aéreas.

A partir das imagens georreferenciadas foram traçadas as linhas de costa no limite entre a vegetação e a faixa de areia, em face do objetivo de se analisar o efeito de frentes frias na região de estudo. Para calcular o taxa de variação da linha de costa foi utilizado o método do EPR (End Point Rate) da extensão DSAS. O princípio é obter a distância de movimentação da linha de costa entre dois períodos distintos e dividi-la pelo tempo transcorrido, fornecendo, assim, a taxa anual de migração em metros. Então foram confeccionados mapas temáticos para análise e apresentação dos resultados. 


\section{4 - Aquisição dos dados Oceanográficos e Meteorológicos}

\subsection{1 - Monitoramento das Frentes Frias}

A fim de se monitorar as condições meteorológicas durante a execução dos levantamentos de campo foram adquiridas sínteses sinóticas disponibilizadas pelo Centro de Previsão de Tempo e Estudos Climáticos (CPTEC) do INPE, em caráter mensal no site http://www.cptec.inpe.br/. Tais sínteses fornecem o deslocamento dos principais sistemas meteorológicos que atuaram na América do Sul a norte do paralelo $40^{\circ} \mathrm{S}$, além de uma análise das anomalias de precipitação e temperatura atmosférica no período.

\subsection{2 - Ondas}

Os dados de onda que serão usados para a discussão dos resultados obtidos em campo e também nas simulações do SMC foram adquiridos no site do Programa Nacional de Boias (PNBOIA) (http://www.mar.mil.br/dhn/chm/meteo/prev/dados/dados.htm). As boias se encontram aproximadamente sobre a isóbata de $200 \mathrm{~m}$ de profundidade, nas proximidades da quebra da plataforma, os dados contêm características básicas de ondas, como período, altura e direção. Os dados utilizados foram coletados pela boia localizada no litoral de São Paulo, nas coordenadas aproximadas de $25^{\circ} 16^{\prime} 52.66^{\prime \prime S ~ e ~} 45^{\circ} 55^{\prime} 32.93 " \mathrm{~W}$, no período entre 05/2011 e 07/2012.

Foram utilizados os dados de altura de onda $(H)$, período $(T)$ e direção das ondulações incidentes durante o período de campanhas a campo. Houve necessidade de tratamento dos dados para eliminar valores espúrios para os parâmetros $\mathrm{H}$ e T, para tanto foi adotado um critério de eliminação se a 
diferença entre um determinado dado e a média mensal fosse maior que três desvios padrões, ou seja:

$$
\begin{aligned}
& \text { se }(a-m)>3 \sigma, \text { o dado é descartado, } \\
& \text { onde, } \\
& a=\text { dado singular, } \\
& m=\text { média mensal, } \\
& \sigma=\text { desvio padrão. }
\end{aligned}
$$

Quanto às observações a cerca das direções dos trens de ondulação decidiu-se por excluir dados com valores entre $22,5^{\circ}$ e $247,5^{\circ}$, devido a geografia e orientação da área de estudo. A partir dos dados tratados foram confeccionados gráficos relacionando os parâmetros $\mathrm{H}$ e $\mathrm{T}$ das ondulações com suas respectivas direções.

As direções de propagação de onda foram distribuídas em 16 subdivisões conforme seu quadrante de origem. A tabela 1 discrimina 0 intervalo adotado para cada subdivisão.

\begin{tabular}{ll}
\hline Direções & Intervalo em Graus \\
\hline NE & 22,5 a 56,25 \\
ENE & 56,25 a 78,75 \\
\hline E & 78,75 a 101,25 \\
ESE & 101,25 a 123,75 \\
SE & 123,75 a 146,25 \\
SSE & 146,25 a 168,75 \\
S & 168,75 a 191,25 \\
SSW & 191,25 a 213,75 \\
SW & 213,75 a 236,25 \\
\hline WSW & 236,25 a 247,5 \\
\hline
\end{tabular}

Tabela 1: Direções adotadas e seus respectivos intervalos. 


\subsection{3 - Precipitação, Vento, Pressão e Maré}

Os dados referentes a precipitação são provenientes das estações meteorológica e maregráfica localizadas na base de apoio do IOUSP em Cananéia. Estes foram adquiridos a partir do LabDados do IOUSP que cuida dos equipamentos de aquisição de dados ambientais nas bases de apoio do Instituto.

A estação meteorológica é automatizada e conta com sensores cs215 para medição de temperatura e umidade, 05106 para medição da velocidade e direção do vento, cs300 para aquisição de dados de radiação solar, e te525 para medição da chuva. O marégrafo digital é da marca AOtt, modelo Kalesto.

Infelizmente, durante no início do período de coletas a campo houve uma pane nos equipamentos de medição, só havendo dados de vento, pressão e maré a partir de outubro de 2011.

\subsection{4 - Batimetria}

Para elaboração da grade batimétrica foram utilizados dados baseados em cartas náuticas e folhas de bordo (previamente digitalizadas). As cartas náuticas digitalizadas foram as de número 1800 e 1700, cedidas pelo mestrando Filipe Galiforni Silva referentes a costa do estado São Paulo, mais especificamente a região de Ilha Comprida e Cananéia.

\section{5 - Utilização do Sistema de Modelagem Costeira (SMC)}

O Sistema de Modelagem Costeira (SMC) é uma ferramenta computacional que agrega uma série de modelos numéricos, estruturados de acordo com as escalas temporais e espaciais dos processos a modelar. Este conjunto de programas permite gerar diferentes cenários na região costeira, 
como instrumento de avaliação na identificação de como o sistema responde as diferentes forçantes que o controlam como o regime de ondas, transporte sedimentar litorâneo e influência das obras de engenharia costeira. O Sistema de Monitoramento Costeiro (SMC) foi desenvolvido pelo Grupo da Universidade de Cantábria, sob a orientação do Governo da Espanha, através do Ministério correspondente ao Ministério do Meio Ambiente do Brasil (GIOC, 2003).

O SMC está estruturado em cinco módulos fundamentais: (1) pré processo; (2) análise de curto prazo de praias (ACORDES); (3) análise de médio e longo prazo de praias (ARPA); (4) modelo de terreno (MMT) e (5) tutorial de engenharia (Figura 19).

\begin{tabular}{|c|c|c|}
\hline \multicolumn{3}{|c|}{ 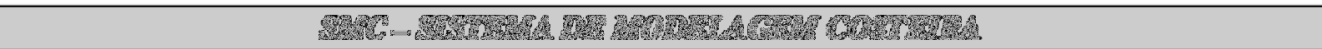 } \\
\hline & 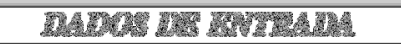 & 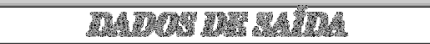 \\
\hline 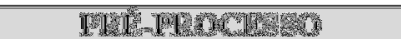 & $\Leftrightarrow$ & $\approx$ \\
\hline 1) & 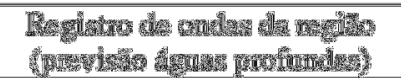 & 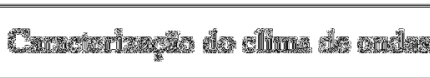 \\
\hline 2) & 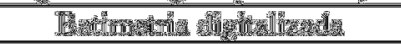 & 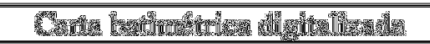 \\
\hline 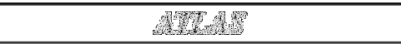 & 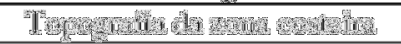 & B \\
\hline ACrlkIns & $\Leftrightarrow$ & $=$ \\
\hline 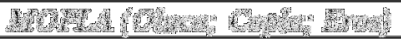 & $=$ & $e$ \\
\hline 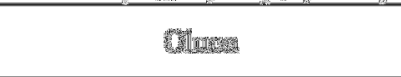 & "I) & 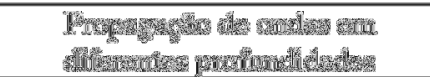 \\
\hline 6. & 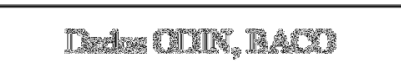 & 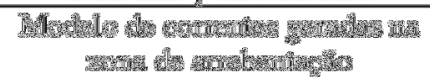 \\
\hline Thx & 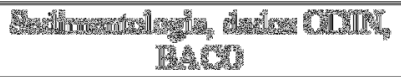 & 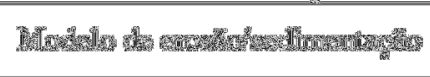 \\
\hline 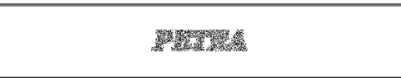 & 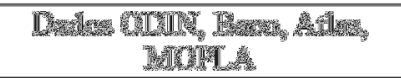 & 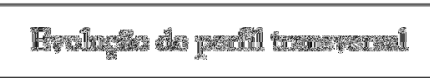 \\
\hline AlOM & 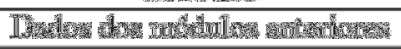 & 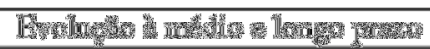 \\
\hline 1TII & 10. & 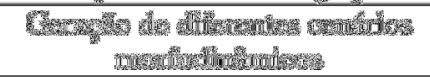 \\
\hline 119 & 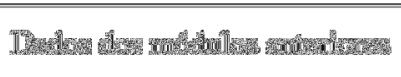 & 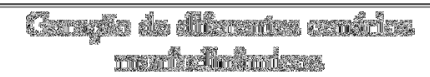 \\
\hline
\end{tabular}

Figura 19: Módulos do Sistema de Modelado Costeiro (SMC) com respectivos dados de entrada e saída.

Devido à falta de dados acerca da batimetria de detalhe e das ondulações atuantes na área de estudo, se torna impossível a validação de qualquer modelo numérico. Com intuito de se caracterizar qualitativamente a ação dos distintos trens de onda atuantes na área de trabalho se optou pela 
utilização do módulo Oluca do Modelo Mopla. Os outros módulos presentes neste modelo, Copla e Eros, não foram aplicados em face da já mencionada falta de dados essenciais e também pelo fato de na área de estudo se encontrar a Desembocadura de Cananéia, cujas correntes de maré e descarga fluvial não poderiam ser simulados pelo sistema SMC.

O modelo Mopla, assim como todos os modelos numéricos, apresenta limitações devido aos pressupostos adotados para simplificar os cálculos executados. O módulo de onda espectral OLUCA-SP (GIOC, 2003) é um modelo debilmente não linear baseado no modelo de refração e difração REF/DIF (Kirby et al., 1994) da Universidade de Delaware (EUA), que resolve a equação da pendente suave à partir de sua aproximação parabólica. Este modelo pode ser classificado como um modelo não dispersivo em amplitude, que resolve a fase da onda sobre batimetrias complexas.

A aproximação parabólica amplia a validade da teoria dos raios até a costa, permitindo a difusão de energia, com cálculos de ondas propagadas numa certa direção, mas, também na direção contrária. A equação da pendente suave do modulo OLUCA não resolve a superfície livre para momentos específicos baseados nas equações de quantidade de movimento de fluxo de massa, e, sim calcula os efeitos combinados dos processos de refração e difração, através de suas equações, sempre que a hipótese da linearidade seja aceitável (Liu e Losada, 2000).

Para o OLUCA resolver a equação da pendente suave através da aproximação parabólica implica em algumas limitações: (1) somente são propagadas ondas cuja direção de propagação esteja entre +/- 55ํㅡ, em relação à orientação da malha (eixo x); (2) aceita uma pendente máxima de 1/3 $(\tan \beta \leq$ 
1/3); (3) não há reflexão de ondas e (4) o número de divisões e subdivisões da malha de cálculo é limitado, tornando-o aplicável apenas a domínios pequenos (menores que $10 \mathrm{~km}$ ).

Assim, o modelo OLUCA é usado para calcular as condições de onda resolvendo bem a difração e a quebra de ondas, além de ser acoplado ao modelo COPLA, que resolve as correntes geradas pela quebra de ondas e está acoplado ao modelo EROS, de transporte de sedimentos.

\section{6 - Determinação das Cotas de Inundação}

Os impactos da incidência de eventos atmosféricos extremos envolvem a ação conjunta de varias forçantes físicas. A singularidade inerente as interações de tais forçantes faz com que uma tempestade possa ser tratada como um evento único, tornado a definição de sua área de atuação e magnitude dos impactos decorrentes um processo intrincado.

Uma simplificação eficaz para gestão de áreas costeiras é a determinação áreas sujeitas ao maior risco de inundação durante a ocorrência de eventos atmosféricos extremos. Trabalhos como Benavente et al. (2006), Maia (2010) e Vieira da Silva (2012) se valem as somatória dos efeitos das principais forçantes físicas causadoras das marés meteorológicas para definição das cotas de máxima inundação associadas as tempestades. Os autores usaram dados medidos em campo e resultados de modelos numéricos para determinar e somar os efeitos da ação do vento (wind set up), da variação da pressão (barometric set up), da incidência de ondas (wave set up e run up, altura e período) e dos ciclos de maré para obter a cotas de inundação de eventos com diferentes intensidades. 
Dada a complexidade envolvida e os dados disponíveis, optou-se por adaptar a metodologia aplicada em Costa et al. (2010) para delimitação das áreas mais sujeitas a risco de inundação. As equações utilizadas pelos autores foram modificadas para se adequarem a melhor a condições locais, resultando em:

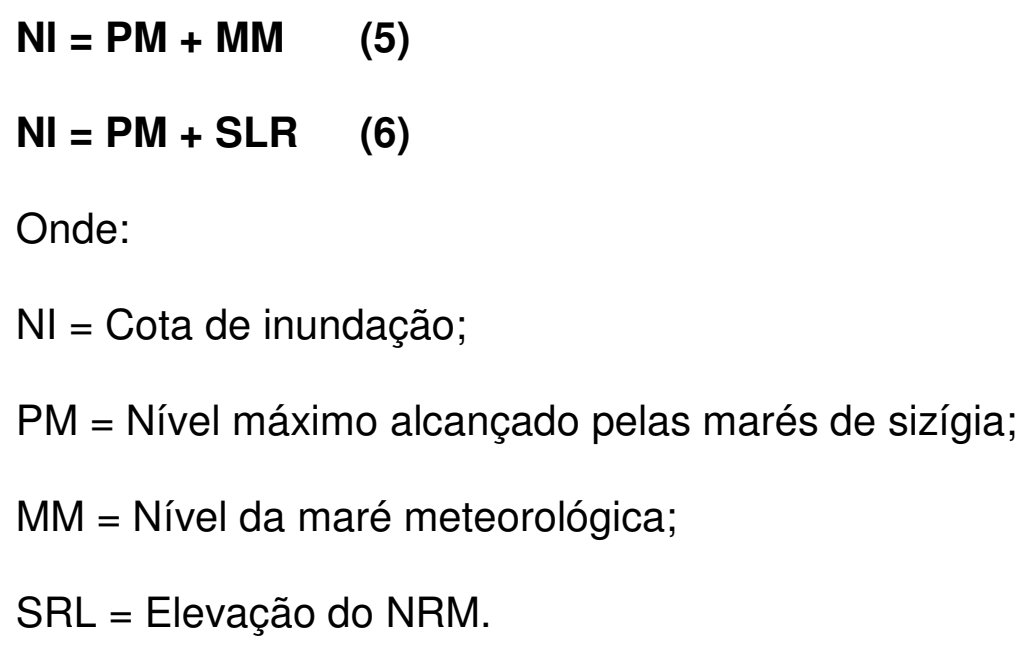$$
\mathrm{NI}=\mathrm{PM}+\mathrm{SLR}
$$

Onde:

$\mathrm{NI}=$ Cota de inundação;

PM = Nível máximo alcançado pelas marés de sizígia;

MM = Nível da maré meteorológica;

$\mathrm{SRL}=$ Elevação do NRM.

Os valores de maré meteorológica foram obtidos dos resultados dos trabalhos de Parise et al.(2009) e Campos et al. (2010). O efeito da aceleração da elevação NRM foi obtido do relatório do IPCC (2007). As amplitudes das marés foram obtidas dos resultados de Mesquita \& Harari (1983) e das tábuas de maré publicadas pelo Instituto Oceanográfico (Harari \& Mesquita, 2011).

Os valores de oscilação de maré normalmente são referenciados ao nível de referência adotado pela Diretoria Hidrografia e Navegação da Marinha do Brasil (DHN), sendo este correspondente a média das baixas mares de sizígia (Mean Low Water Springs - MLWS). Para a sobreposição desses valores aos MDTs criados, que estão referenciados ao nível zero do IBGE, foi necessária a correção do datum vertical.

O datum do IBGE é referenciado ao Nível Médio do Mar (Mean Sea 
Level - MSL), obtido a partir da série histórica de nível do mar do maregráfo de Imbituba, em Santa Catarina. Nas cartas náuticas da DHN, estão contidos tanto os valores de MLS quanto os valores de MLWS, que apresentam variação local. A correção vertical foi executada por meio da subtração dos valores de MLS contidos na carta náutica número 1703 da DHN dos níveis de marés encontrados.

Foi dada prioridade aos resultados obtidos por Campos et al. (2010) devido a maior proximidade da área do atual estudo a cidade de Santos, região abordada pelos autores. Os autores determinaram as ocorrências de marés meteorológicas em Santos por meio da analise de uma série temporal de elevação nível do mar no período entre 1951 e 1990. Foi estabelecido como limite de detecção de eventos anômalos 2 desvios-padrões, ou seja, só foram selecionados casos que apresentaram pelo menos $+0,34 \mathrm{~m}$ ou $-0,34 \mathrm{~m}$ de elevação do nível do mar. Os resultados dos autores ainda indicam o valor de +/-1 m como limite extremo de variação anormal do nível do mar.

O estudo de Parise et al.(2009 abrange a região Sul do país, o estado do Rio Grande do Sul mais especificamente. Nesta região o fenômeno da maré meteorológica costuma ser mais intenso devido a proximidade geográfica das áreas de formação dos sistemas atmosféricos. Os valores obtidos neste estudo foram tratados como situações extremas associadas a eventos com grande período de retorno. Entretanto, deve se salientar que os resultados de Parise et al.(2009) foram obtidos por medidas diretas em situ, tornando-os mais confiáveis do que os resultados obtidos indiretamente por Campos et al. (2010).

Com base em tais informações foram elaborados os casos para serem 
sobrepostos ao MDT referente ao dia 26/02/2012. Devido a falta de dados acerca das regiões mais interiores da área de estudo, adicionou-se ao MDT dados obtidos do modelo digital de elevação global utilizado pelo software Goggle Earth ${ }^{\circledR}$. Para tornar mais fácil a compreensão dos resultados foi sobreposta ao MDT a imagem de satélite de 2009, também adquirida no softwere Goggle Earth ${ }^{\circledR}$.

Os resultados obtidos devem ser tratados com cautela, sendo considerados indicativos das áreas mais vulneráveis. Deve se salientar que não estão sendo levados em consideração uma série de fatores importantes para o refinamento da delimitação das cotas de inundação, como a estimativa de velocidade do run up, porosidade dos sedimentos, percolação da água, coeficientes de arrasto nas dunas, influência do lençol freático, ocorrências de séries de tempestades (Maia, 2010).

\section{6 - Resultados}

\section{1 - Condições Ambientais}

Os dados coletados acerca da variação da maré, incidência de ventos, e variação de pressão abrangem somente os período entre outubro de 2011 e fevereiro de 2012. Devido este lapso na série temporal e dos resultados alcançados nas analises dos dados topográficos, decidiu-se em expor somente os dados referentes a precipitação, os quais estão disponíveis para todo o período de coleta. 


\subsection{1 - Frentes Frias}

A passagem de frentes frias foi obtida através da análise das sínteses sinóticas emitidas pelo CPTEC. As figuras de 20 a 29 ilustram a passagem de frentes frias pelo litoral brasileiro entre os meses de 05/2011 a 02/2012.

A figura 20 expõem as frentes frias que ocorreram no mês de maio de 2012, apesar de terem sido registradas 7 frentes no total, somente duas chegaram a influenciar a área de estudo, situada entre Paranaguá e Iguape, sendo estas a ocorrência de número 3 e a ocorrência de número 7 . No texto da síntese não há menções de ondas grandes, porém na saída de campo preliminar realizada neste mês ficou claro a influência da passagem de uma frente fria significativa, pois ocorreu até mesmo queda de estruturas para proteção do sol nos quiosques localizados a beira-mar, e havia a presença clara de uma escarpa de erosão na face praial.

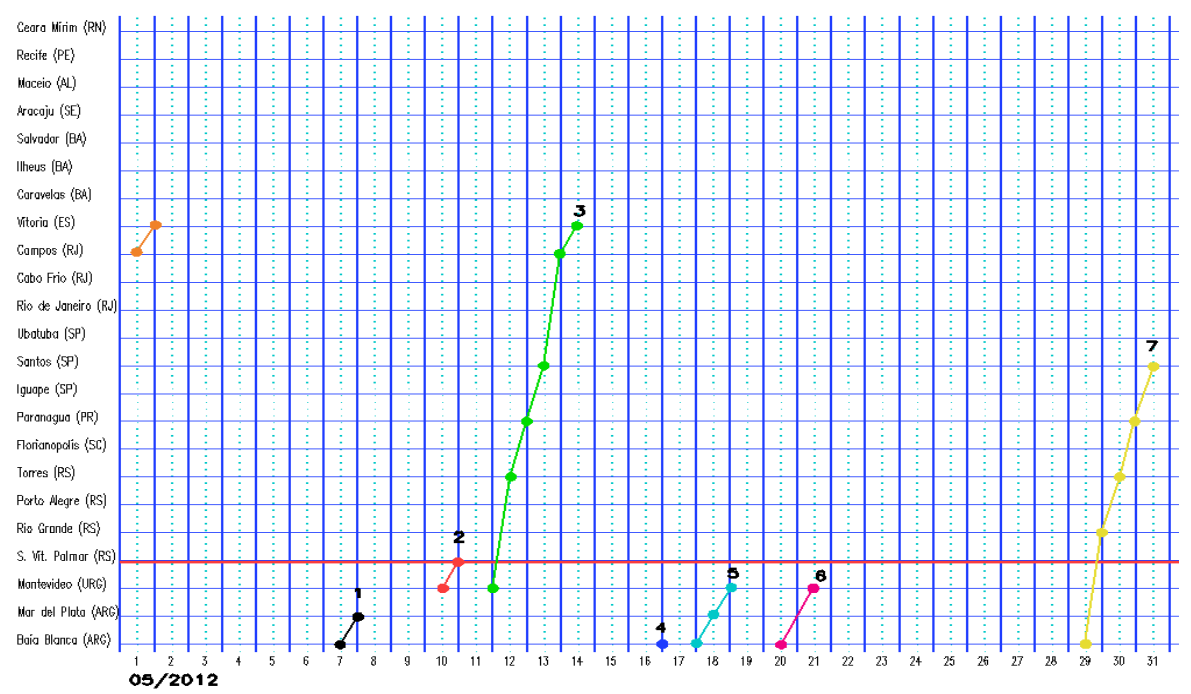

Figura 20: Ocorrências de frentes frias no mês de maio de 2011 no litoral brasileiro. Extraído da Síntese Sinótica Mensal do CPTEC.

No mês de junho de 2011 houve a passagem de 8 frentes no litoral brasileiro, como exposto na figura 21, porém somente três sistemas 
atmosféricos exerceram influência no local de estudo (1,4 e 8).

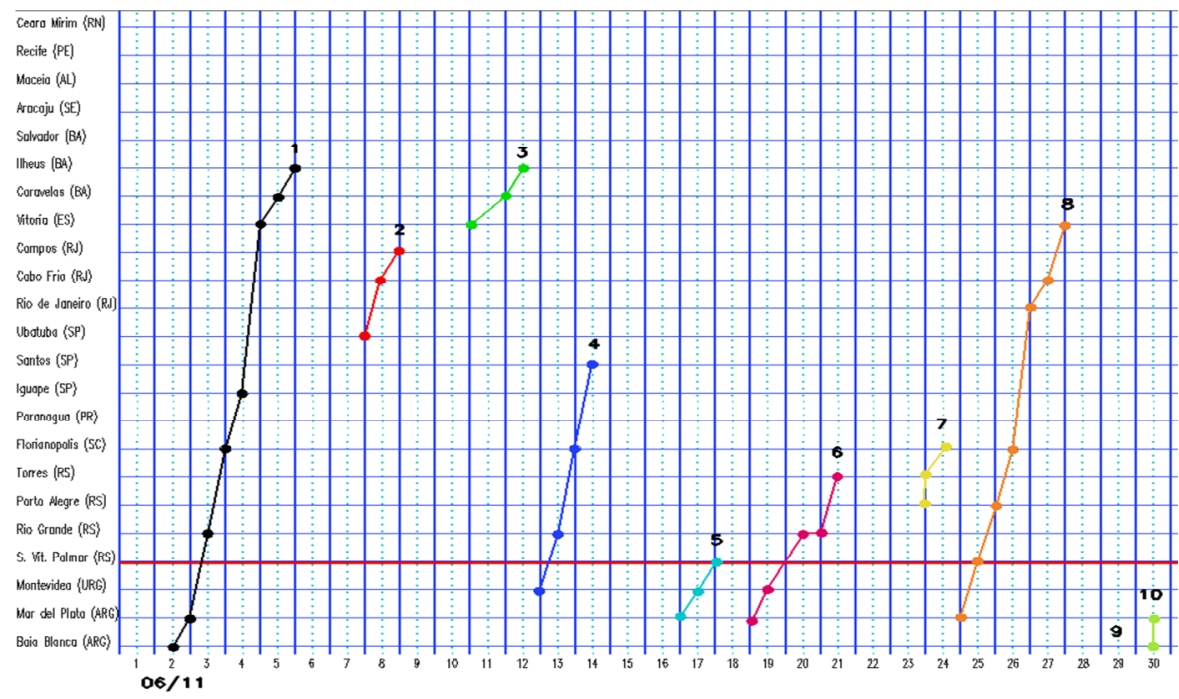

Figura 21: Ocorrências de frentes frias no mês de junho de 2011 no litoral brasileiro.

Extraído da Síntese Sinótica Mensal do CPTEC.

A figura 22 diz respeito aos sistemas frontais que ocorreram no mês de julho de 2011, totalizando 5 ocorrências no litoral brasileiro. A área de estudo do presente trabalho foi afetada por 2 desses sistemas, sendo estes as ocorrências número 3 e 5 . Um outro sistema frontal que teve seu início no mês anterior também afetou a região . 


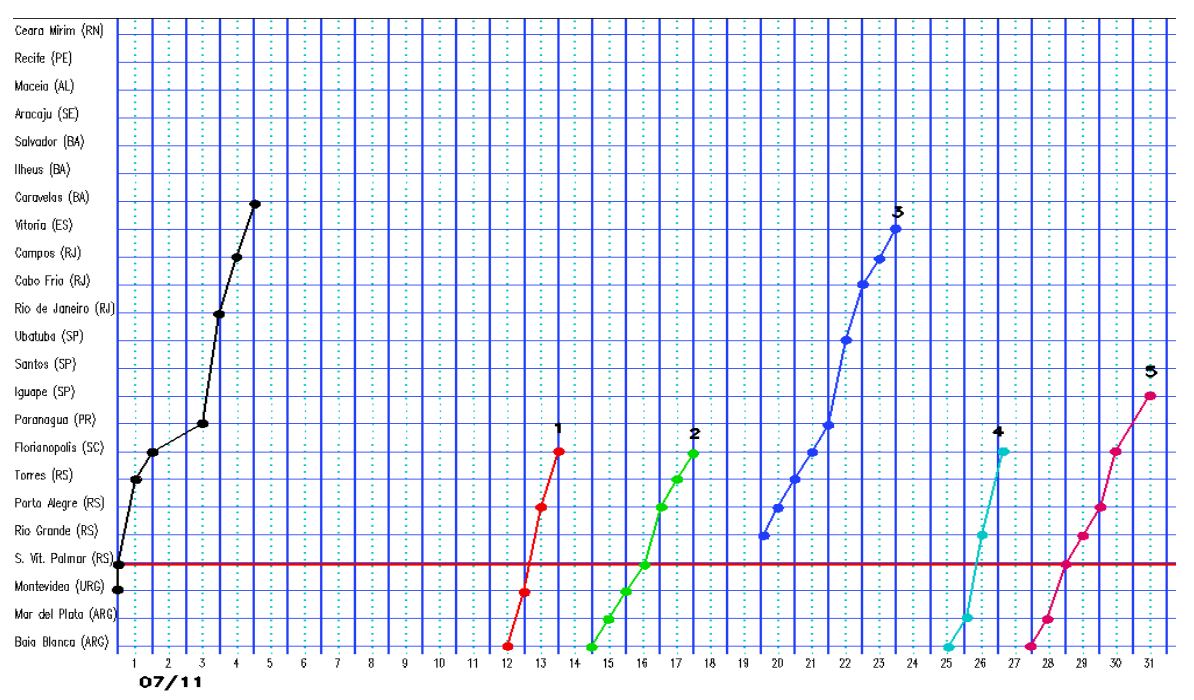

Figura 22: Ocorrências de frentes frias no mês de julho de 2011 no litoral brasileiro. Extraído da Síntese Sinótica Mensal do CPTEC.

A figura 23 expõem as 9 frentes frias que se formaram no Atlântico Sul no mês de agosto de 2011. Dessas 9 frentes frias, 8 atingiram a costa brasileira e 4 influenciaram a área do estudo, sendo estas as ocorrências 1, 2, 5 e 9. Segundo o texto elaborado pelo CPTEC, ocorreram enchentes no Vale no Ribeira associadas à passagem de uma frente fria nos primeiros dias do mês, acumulando mais de $100 \mathrm{~mm}$ em alguns munícipios. Ainda segundo o texto já mencionado, a quinta ocorrência de frente fria (entre os dias 19 e 22) foi a mais intensa do mês, causando o fenômeno chamado de "friagem", além de o ciclone extratropical associado causar ondas intensas no litoral de São Paulo e Rio de Janeiro, além da ocorrência de um episódio de ressaca neste estado. 


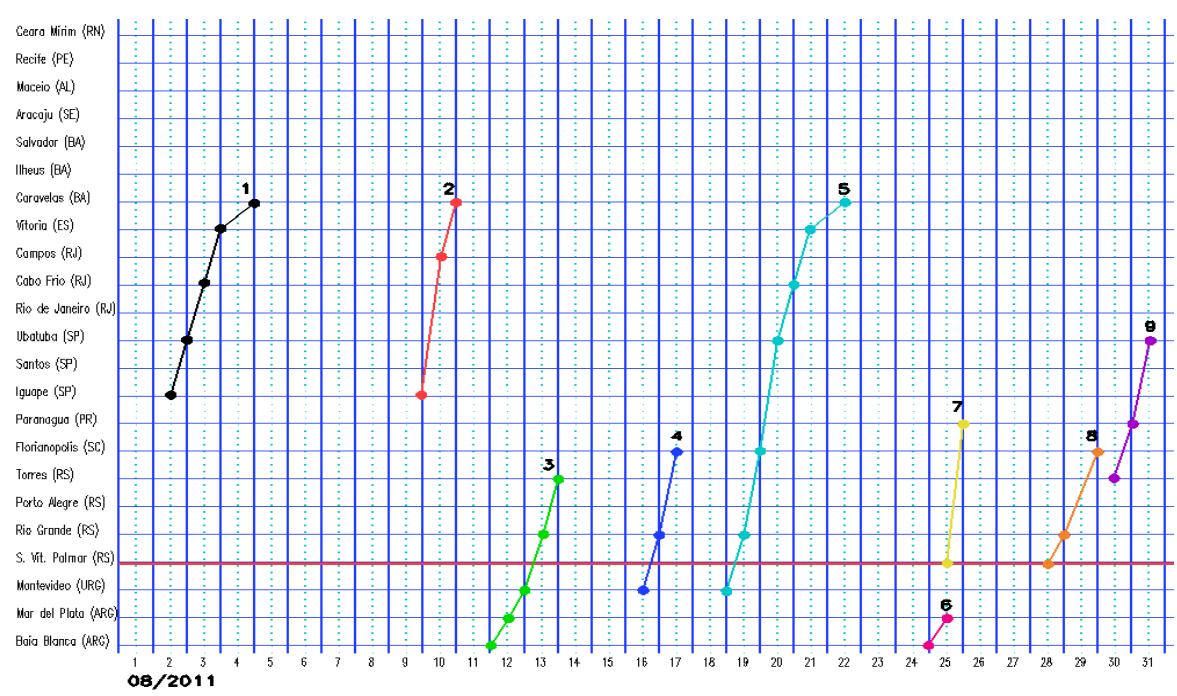

Figura 23: Ocorrências de frentes frias no mês de agosto de 2011 no litoral brasileiro. Extraído da Síntese Sinótica Mensal do CPTEC.

O mês de setembro de 2011 foi caracterizado pela ocorrência de 11 frentes frias no Atlântico Sul, das quais nove adentraram a costa brasileira. Somente as frentes frias número 1, 3, 4, 7 e 9 exerceram influência sobre a área de estudo (figura 24).

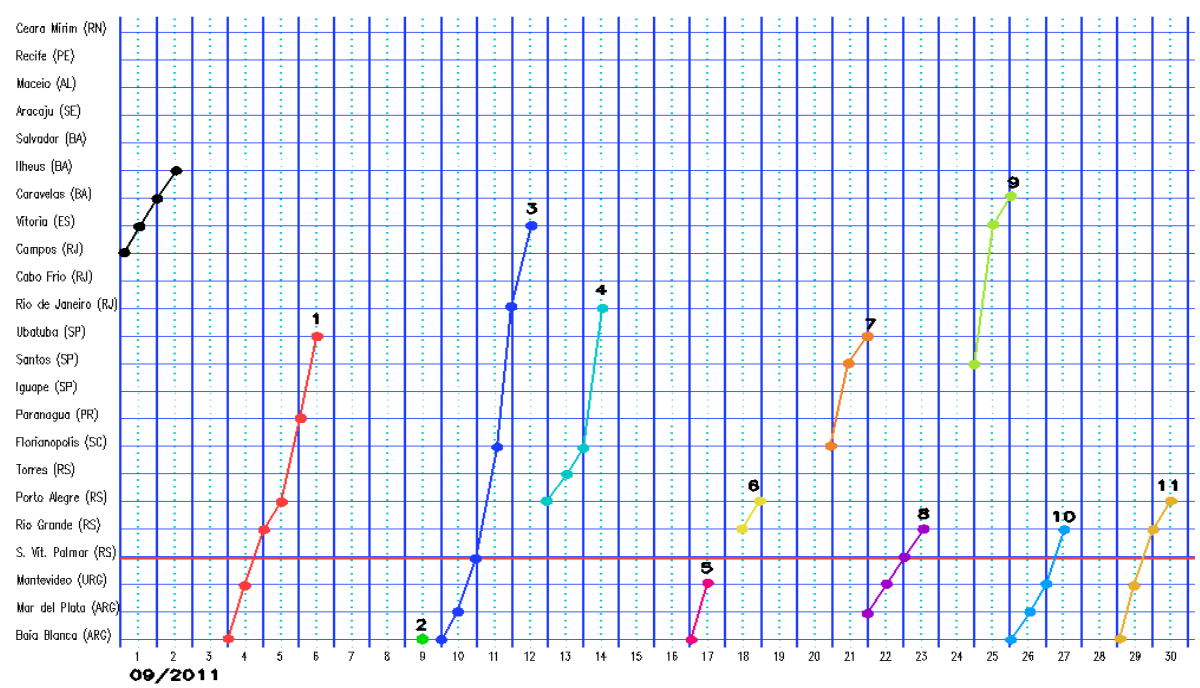

Figura 24: Ocorrências de frentes frias no mês de setembro de 2011 no litoral brasileiro. Extraído da Síntese Sinótica Mensal do CPTEC.

Como pode ser observado na figura 25 , no mês de outubro somente uma das 8 frentes frias atuantes chegou a impactar a zona de estudo, ficando a 
maioria dos sistemas confinados na região sul do país.

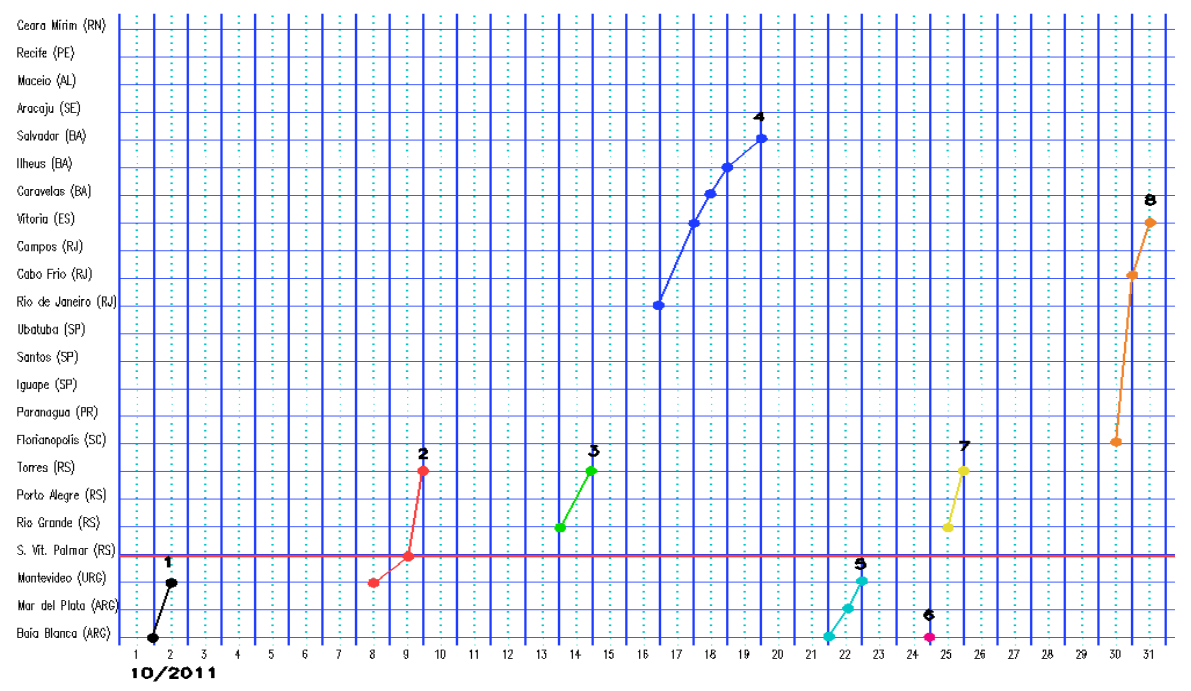

Figura 25: Ocorrências de frentes frias no mês de outubro de 2011 no litoral brasileiro. Extraído da Síntese Sinótica Mensal do CPTEC.

A figura 26 exibe os sistemas frontais atuantes no mês de novembro de 2011, totalizando 5 ocorrências, das quais 3 adentraram a costa brasileira, e somente uma exerceu influência na área de estudo (ocorrência número 2).

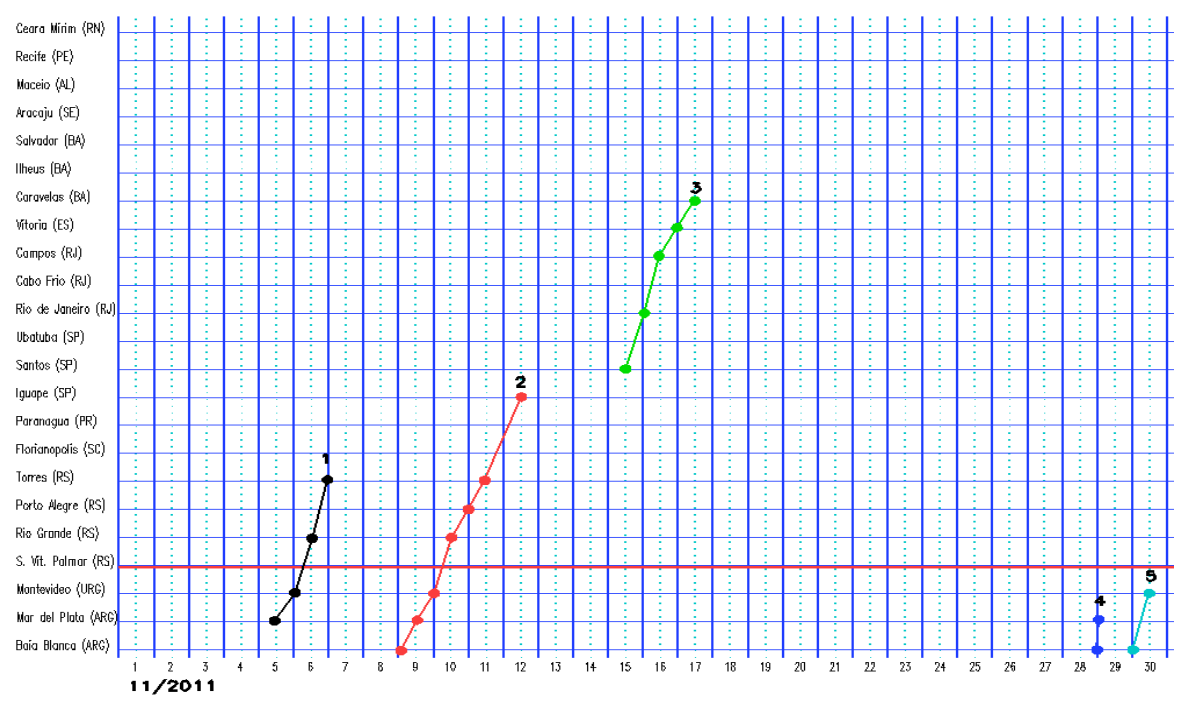

Figura 26: Ocorrências de frentes frias no mês de novembro de 2011 no litoral brasileiro. Extraído da Síntese Sinótica Mensal do CPTEC. 
A figura 27 expõe os sistemas frontais que ocorreram na América do Sul acima do paralelo $40^{\circ}$ no mês de dezembro de 2011. Das 3 ocorrências registradas, 2 adentraram a costa brasileira, passando pela área de interesse (ocorrência 1 e 3).

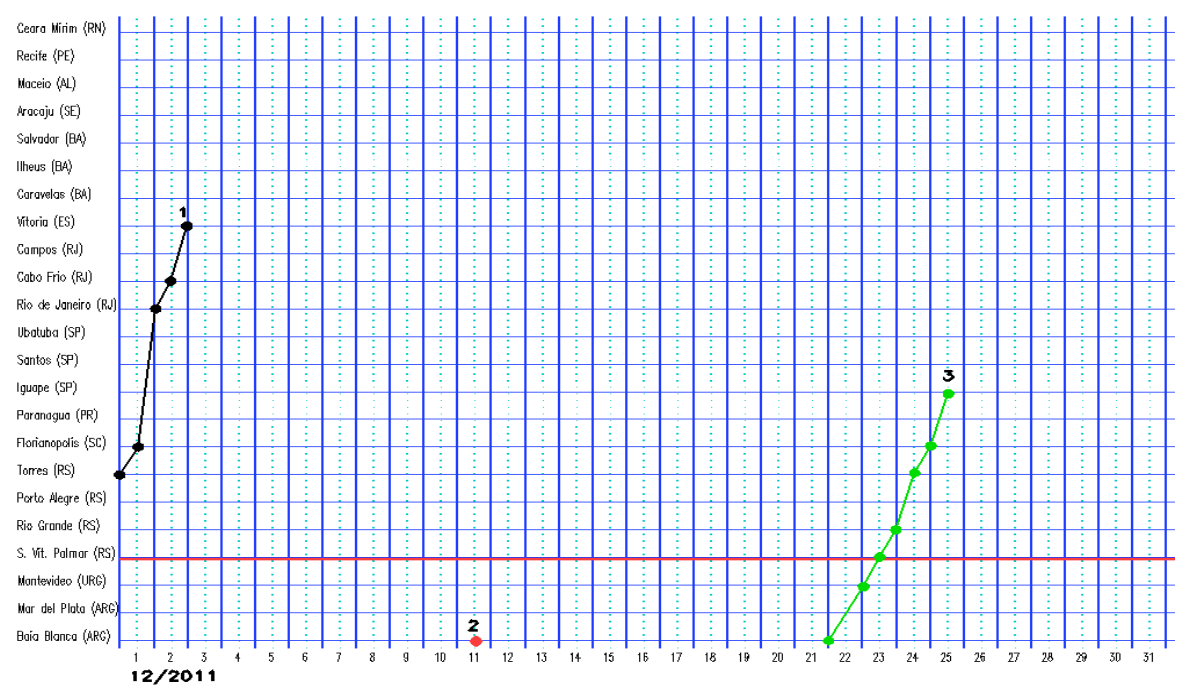

Figura 27: Ocorrências de frentes frias no mês de dezembro de 2011 no litoral brasileiro. Extraído da Síntese Sinótica Mensal do CPTEC.

Os sistemas frontais atuantes no mês de janeiro de 2012 estão dispostos na figura 28, quando foram registradas 6 ocorrências. Contudo, somente a ocorrência número 5 chegou a penetrar o território brasileiro e deslocar até as proximidades da área de interesse do presente trabalho. 


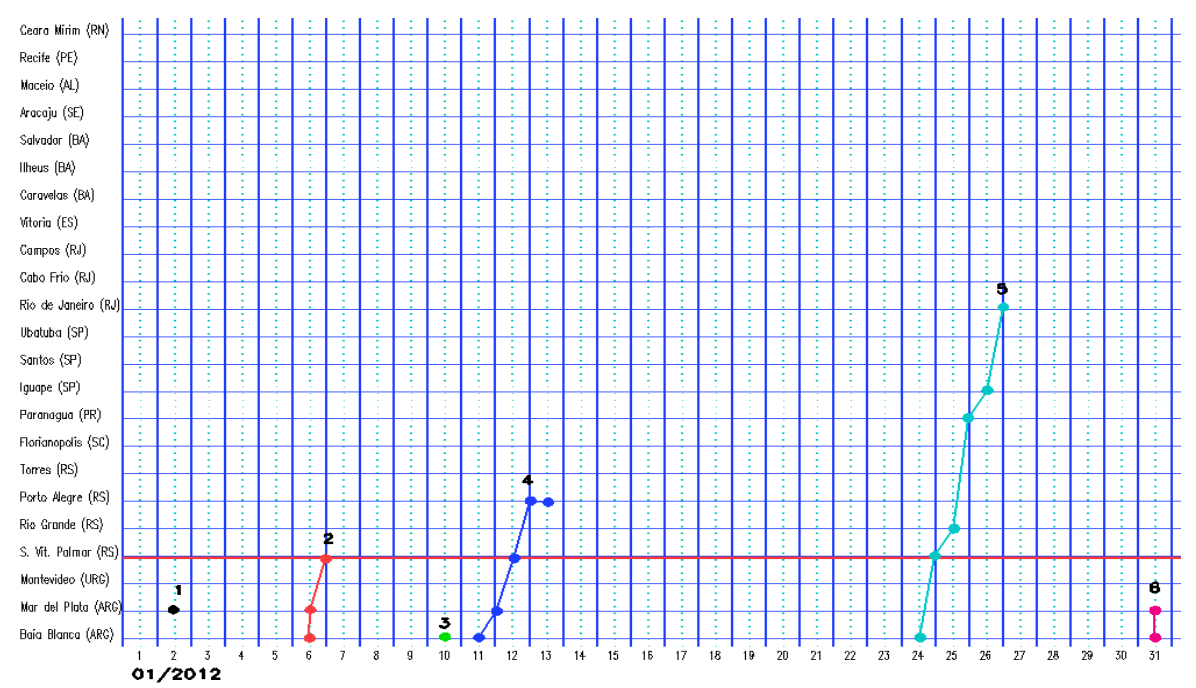

Figura 28: Ocorrências de frentes frias no mês de janeiro de 2012 no litoral brasileiro. Extraído da Síntese Sinótica Mensal do CPTEC.

A figura 29 apresenta as frentes frias identificadas pelo CPTEC em sua síntese sinótica do mês de fevereiro de 2012, apesar de aparecerem 9 registros de atividade frontigênica, nenhum sistema conseguiu chegar até a latitude da área de estudo, caracterizando o único mês sem deslocamento de frentes frias nas regiões próximas ao Vale do Ribeira.

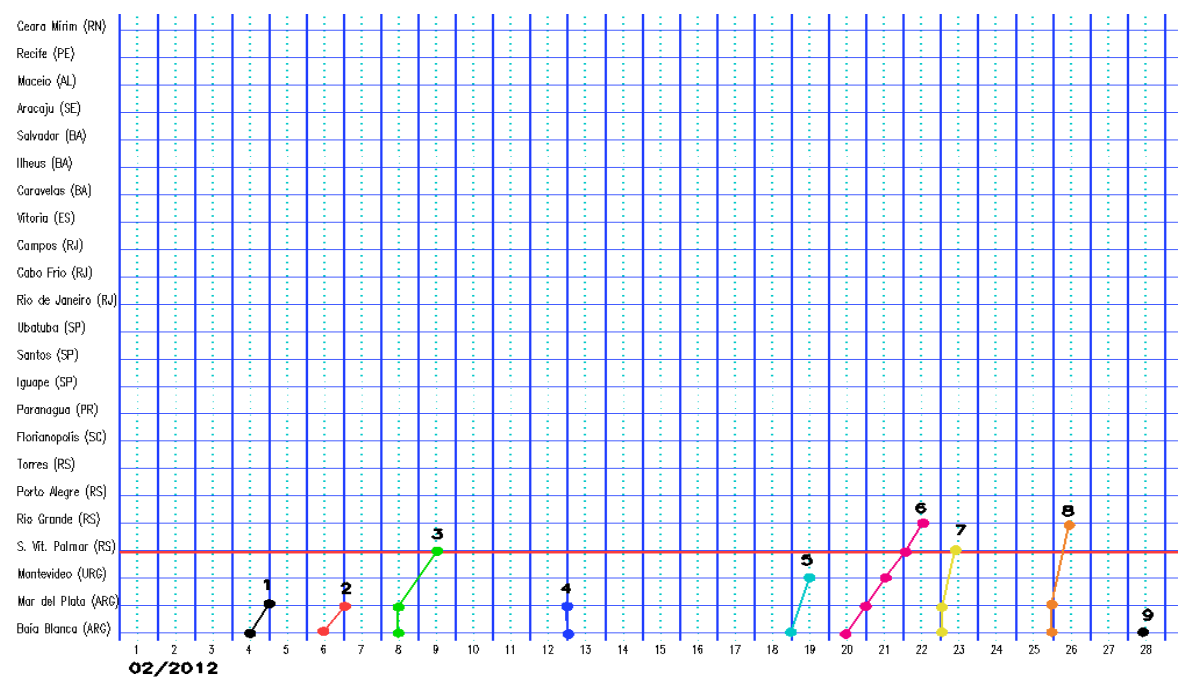

Figura 29: Ocorrências de frentes frias no mês de fevereiro de 2012 no litoral brasileiro. Extraído da Síntese Sinótica Mensal do CPTEC. 
A fim de facilitar a análise, foram elaboradas tabelas confrontando a ocorrência de frentes frias e os dias de saídas a campo, os resultados estão dispostos na tabela 2.
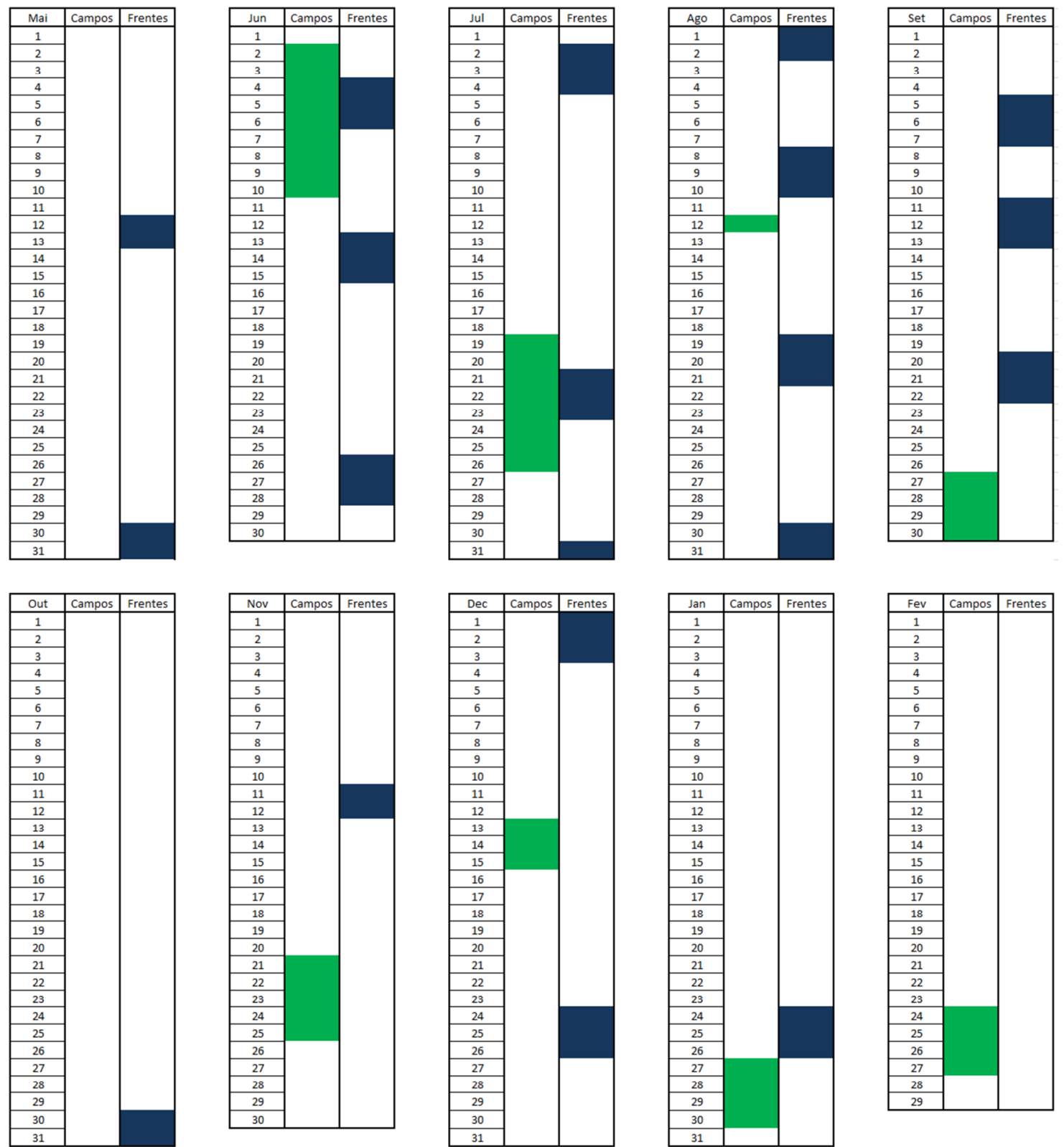

Tabela 2: Comparação entre os dias de ocorrência de frentes frias e os dias de saídas a campo. A coluna da esquerda corresponde ao acontecimento das coletas e a segunda coluna a ocorrência de sistemas frontais. 


\subsection{2 - Ondas}

Os dados de onda foram separados em períodos mensais para facilitar sua compreensão e interpretação. Deve-se ressaltar que os dados são referentes a ondulações registradas aproximadamente na isóbata de 200 m. Os resultados obtidos estão dispostos na forma de "rosas de ondas", que associam direção de propagação com altura e período, sendo a figura da esquerda correspondente às alturas e a figura da direita ao período, os resultados estão expressos respectivamente em metros e segundos.

A figura 30 expõe as rosas de ondas para o mês de maio de 2011, onde pode ser observada a predominância de ondas provindas das direções $S$ e SSW, com $57 \%$ das ondulações registradas. A maior parte das ondas apresentou alturas entre 1,5 e $3 \mathrm{~m}$ (cerca de 80\%), com valor máximo de 5,5 m. Aproximadamente $50 \%$ das observações acerca dos períodos ficaram entre 9 e 12 s, com o máximo na casa dos $16 \mathrm{~s}$.
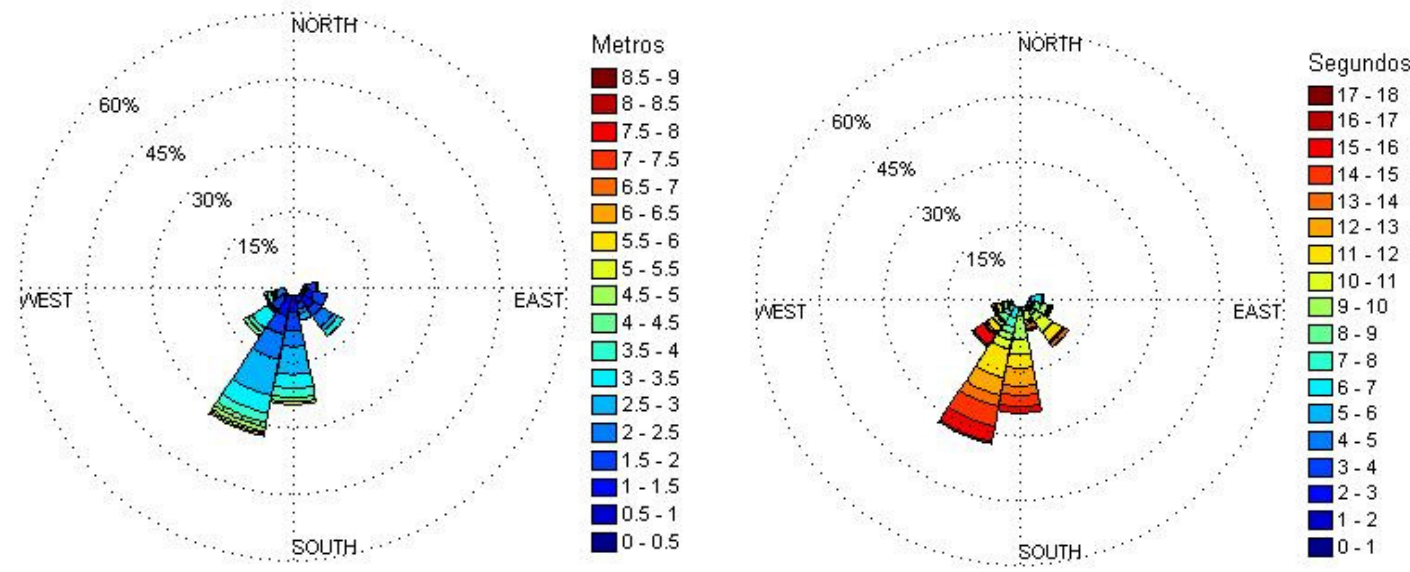

Figura 30: Rosas de Ondas para 05/2011. Gráfico da direita referente à altura de ondas por direção de propagação e gráfico da esquerda referente a período de ondas por direção de propagação, resultados em metros e segundos respectivamente. 
A figura 31 diz respeito ao mês de junho de 2011. Novamente as direções mais representativas foram as direções SSW e S com cerca de 35\% das ocorrências registradas. No entanto neste mês a direção ESE também foi significativa com cerca de $16 \%$ das ondas registradas. Aproximadamente $50 \%$ das alturas observadas ficaram entre 1 e $1,5 \mathrm{~m}$, e cerca de $25 \%$ das ondas apresentaram 2 ou 2,5 m, o máximo observado foi de 5,39 m. A maior parte das observações referentes aos períodos de onda apresentaram valores entre 8 e 13 s $(66,37 \%)$, sendo o período de 11 s o mais frequente com $16,8 \%$ das ocorrências, o máximo registrado ficou na casa dos $16 \mathrm{~s}$.
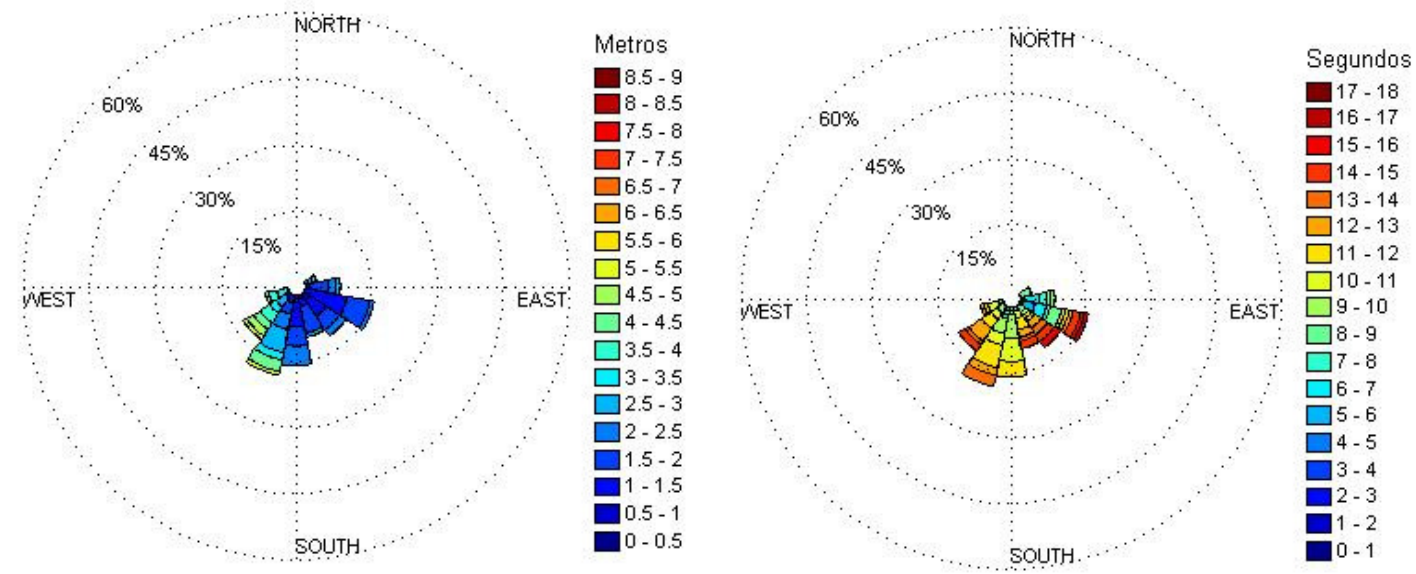

Figura 31: Rosas de Ondas para 06/2011. Gráfico da direita referente a altura de ondas por direção de propagação e gráfico da esquerda referente a período de ondas por direção de propagação, resultados em metros e segundos respectivamente.

Os resultados para o mês de julho de 2011 se encontram na figura 32. Infelizmente, devido a falha da boia de coleta, os resultados para este mês contam apenas com 20 dias. Este mês apresentou uma forte predominância de ondas provindas do setor SW, com $25 \%$ de todas as observações. Os setores SW, SSW, ESE e SE somados corresponderam a cerca de $60 \%$ do total dos dados. O maior percentual de altura de ondas ocorreu entre 1,5 e 2,5 m, totalizando $50 \%$ das observações, já as ondas de 3 a $5,5 \mathrm{~m}$ responderam por 
aproximadamente $35 \%$ por cento do total, e a máxima altura registrada foi de 8,6 m. Os períodos de onda registrados tiveram sua maior frequência no intervalo entre 9 e $10 \mathrm{~s}$, com cerca de $40 \%$ do total de observações, o intervalo entre 6 e 7 s respondeu por $25 \%$ do total analisado, e o período máximo foi de $14 \mathrm{~s}$.
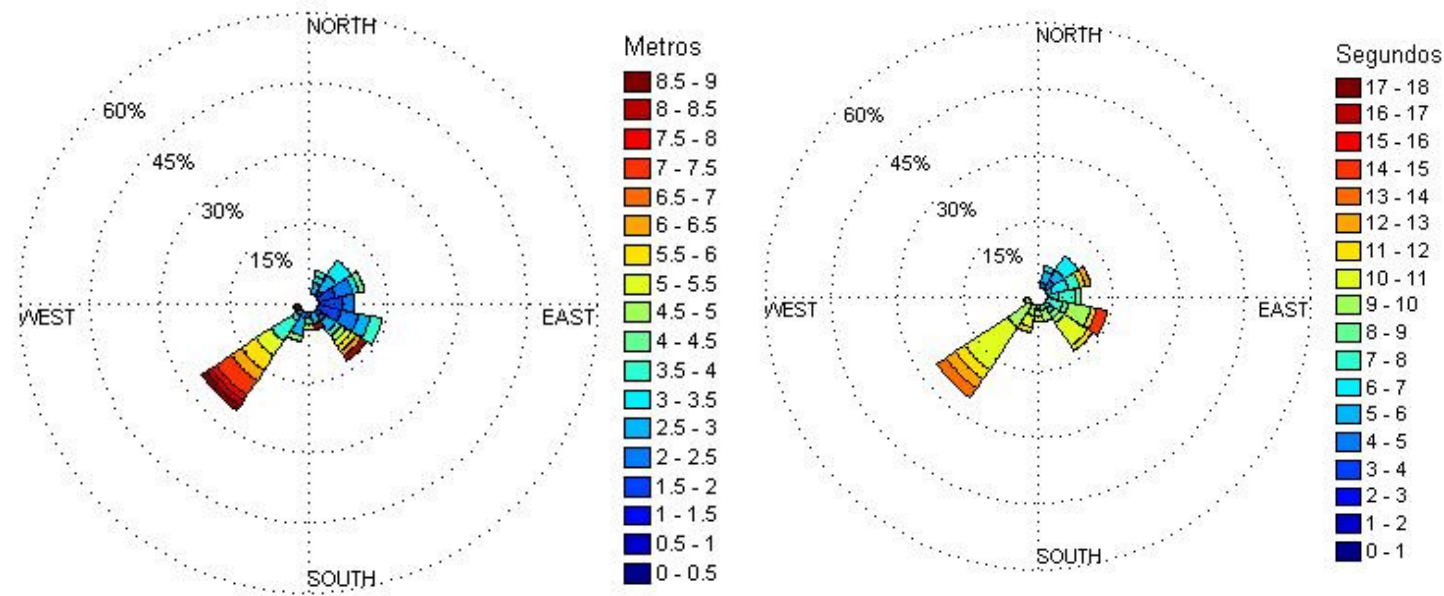

Figura 32: Rosas de Ondas para 07/2011. Gráfico da direita referente à altura de ondas por direção de propagação e gráfico da esquerda referente a período de ondas por direção de propagação, resultados em metros e segundos respectivamente.

Os resultados para o mês de agosto de 2011 estão expostos na figura 33, demonstrando um predomínio da direção SSE englobando aproximadamente $26 \%$ das ondas registradas. $\mathrm{Na}$ verdade este quadrante somado aos quadrantes SE e ESE, correspondem aproximadamente $55 \%$ do total de observações, seguidos pelos quadrantes S, SSW e SW que contam com cerca de $38 \%$ das observações. Cerca de $50 \%$ dos resultados referentes à altura de ondas se enquadraram entre 1,5 e 2 m, e a máxima altura registrada foi de $5,2 \mathrm{~m}$. Os dados referentes ao período de ondas demonstraram predominância na faixa entre 10 e 13 s, que englobou aproximadamente $65 \%$ do total de observações, com o período de 11 s respondendo por cerca de $25 \%$ de todos os dados, o maior período observado foi de $18 \mathrm{~s}$. 

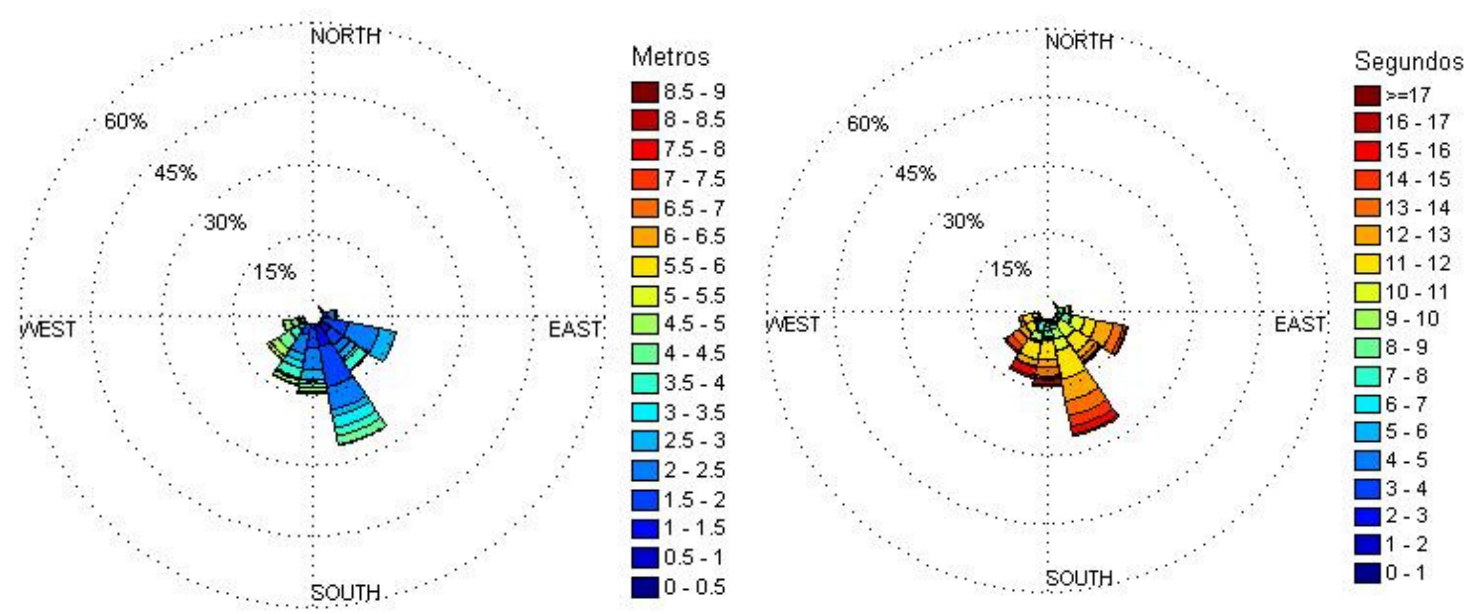

Figura 33: Rosas de Ondas para 08/2011. Gráfico da direita referente à altura de ondas por direção de propagação e gráfico da esquerda referente a período de ondas por direção de propagação, resultados em metros e segundos respectivamente.

A figura 34 diz respeito aos dados do mês de setembro de 2011. Os quadrantes que mais significativos foram o ESE e S, ambos com cerca de $20 \%$ do total observado, sendo $90 \%$ das observações provindas dos quadrantes ESE, SE, SSE, S, SSW e SW. Nos dados referentes a altura de ondas o intervalo 1,5 e $2,5 \mathrm{~m}$ correspondeu a aproximadamente $72 \%$ do total observado, sendo $26 \%$ do total referente a ondas de $2,5 \mathrm{~m}$, o máximo de altura observado foi de $4 \mathrm{~m}$. O valor mais frequente nos dados de período foi de $8 \mathrm{~s}$, com cerca de $15 \%$ do total das observações, estando $75 \%$ das observações localizadas na faixa entre 7 e 12 s, o máximo período observado foi de aproximadamente $15 \mathrm{~s}$. 

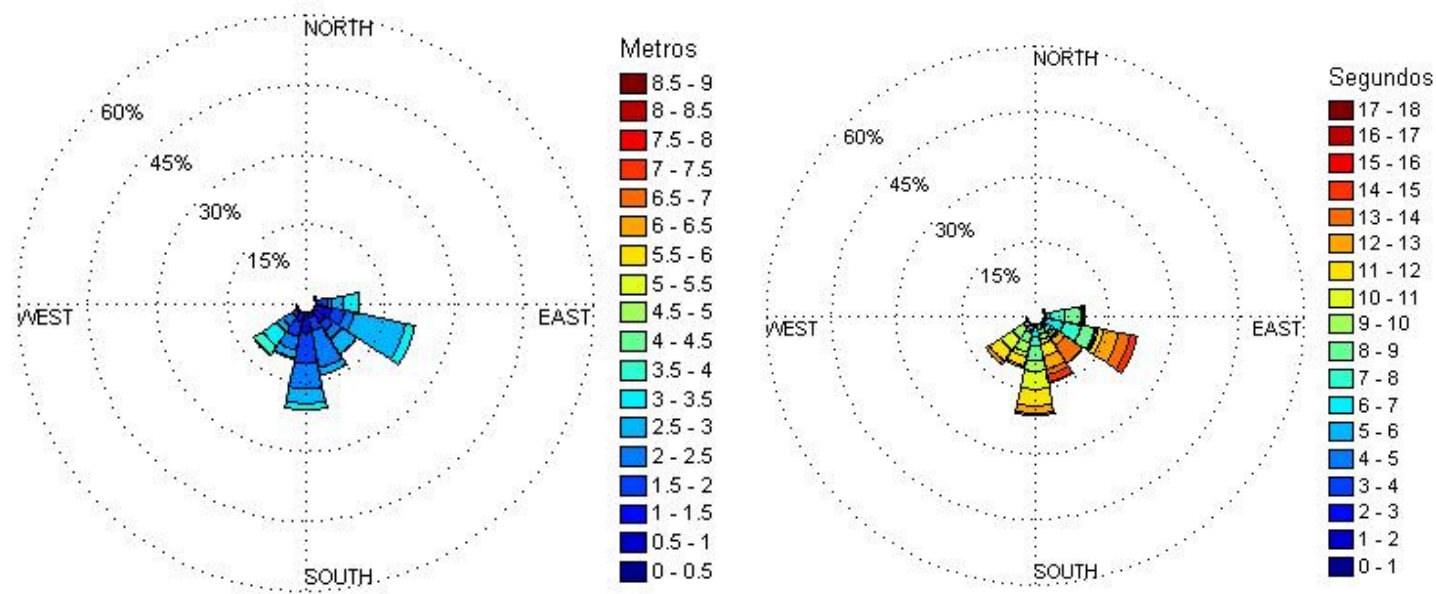

Figura 34: Rosas de Ondas para 09/2011. Gráfico da direita referente à altura de ondas por direção de propagação e gráfico da esquerda referente a período de ondas por direção de propagação, resultados em metros e segundos respectivamente.

A figura 35 apresenta os resultados referentes ao mês de outubro de 2011. Deve se salientar que as observações deste mês apresentaram somente valores inteiros, provavelmente devido a alguma falha no aparelho de medição. Cerca de $90 \%$ das ondulações foram englobadas pelos setores $E$, ESE, SE, SSE e S, com o setor SSE sendo o mais significativo, com aproximadamente $27 \%$ das observações, seguido do setor ESE, que apresentou aproximadamente $22 \%$ do total. As alturas de ondas se concentraram principalmente nos valores de $2 \mathrm{~m}$ (aproximadamente 60\%) e de $3 \mathrm{~m}$ (cerca de 33\%), com o máximo valor observado de $4 \mathrm{~m}$. Cerca de $70 \%$ das observações acerca do período de ondas ficaram na faixa entre 8 e $11 \mathrm{~s}$, sendo os valores de 8 e 9 s os mais frequentes, com aproximadamente $25 \%$ e $22 \%$ do total respectivamente, já o maior período observado foi de $13 \mathrm{~s}$. 

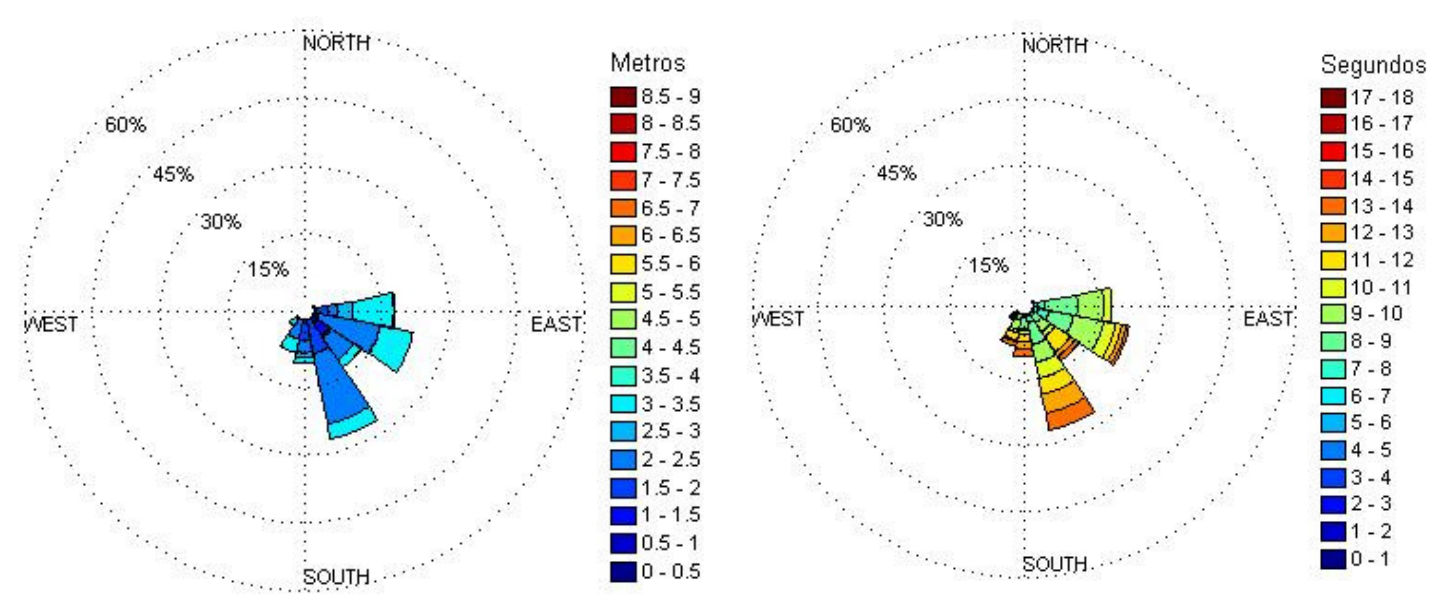

Figura 35: Rosas de Ondas para 10/2011. Gráfico da direita referente à altura de ondas por direção de propagação e gráfico da esquerda referente a período de ondas por direção de propagação, resultados em metros e segundos respectivamente.

Os resultados referentes ao mês de novembro de 2011 estão expostos na figura 36. É possível observar um predomínio das direções E, com cerca de $30 \%$ das observações, e SSE com cerca de $20 \%$ do total. Os dados de altura demonstram uma concentração de observações no intervalo entre 1,5 e 2 m, que respondem por $77 \%$ das ondas observadas, com destaque para o valor 1,5 que conta com aproximadamente $47 \%$ do total, sendo o valor máximo de altura observada de 5,7 m. Cerca de 90\% das observações referentes ao período de ondas se encontram no intervalo entre 6 e $11 \mathrm{~s}$, sendo o valor de $8 \mathrm{~s}$ o mais representativo com cerca de $30 \%$ do total dos dados, seguido pelo período de $9 \mathrm{~s}$ com cerca de $20 \%$ dos registros. O período máximo registrado foi de $16 \mathrm{~s}$. 

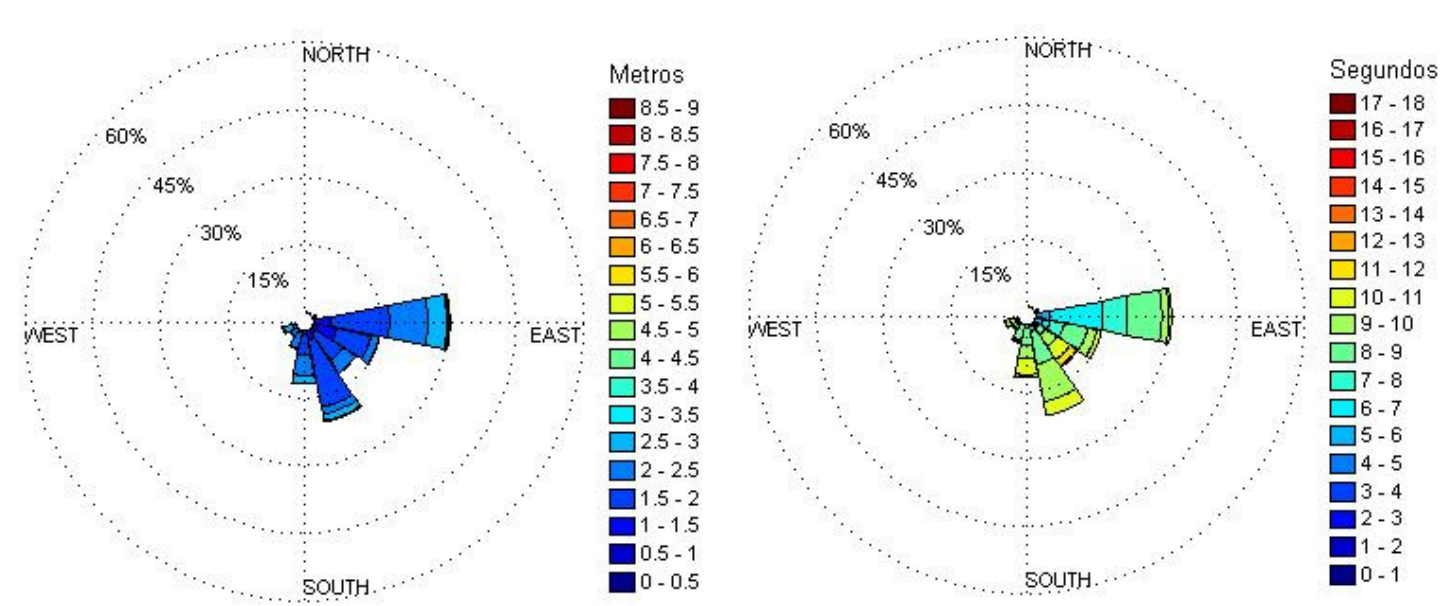

Figura 36: Rosas de Ondas para 11/2011. Gráfico da direita referente à altura de ondas por direção de propagação e gráfico da esquerda referente a período de ondas por direção de propagação, resultados em metros e segundos respectivamente.

Os dados referentes ao mês de dezembro estão dispostos na figura 37, e revelam um predomínio dos setores E e ESE quanto as direções das ondulações, com $28 \%$ e $26 \%$ do total dos dados respectivamente. As demais observações se concentram nas direções SSE (com cerca de 18\%) e S (com aproximadamente 14\%). Aproximadamente $80 \%$ dos acerca das alturas de onda se encontram na faixa entre 1 e $2 \mathrm{~m}$, com destaque para o valor de $1,5 \mathrm{~m}$ com cerca de $35 \%$ do total registrado, o maior valor de altura registrado para este mês foi de 4,5 m. Os dados acerca dos períodos das ondas observadas se concentram no intervalo entre 7 e $9 \mathrm{~s}$, que responde por $65 \%$ do total, sendo 0 valor mais frequente o de $8 \mathrm{~s}$, com 34\% das observações, o maior período observado ficou na casa dos $15 \mathrm{~s}$. 

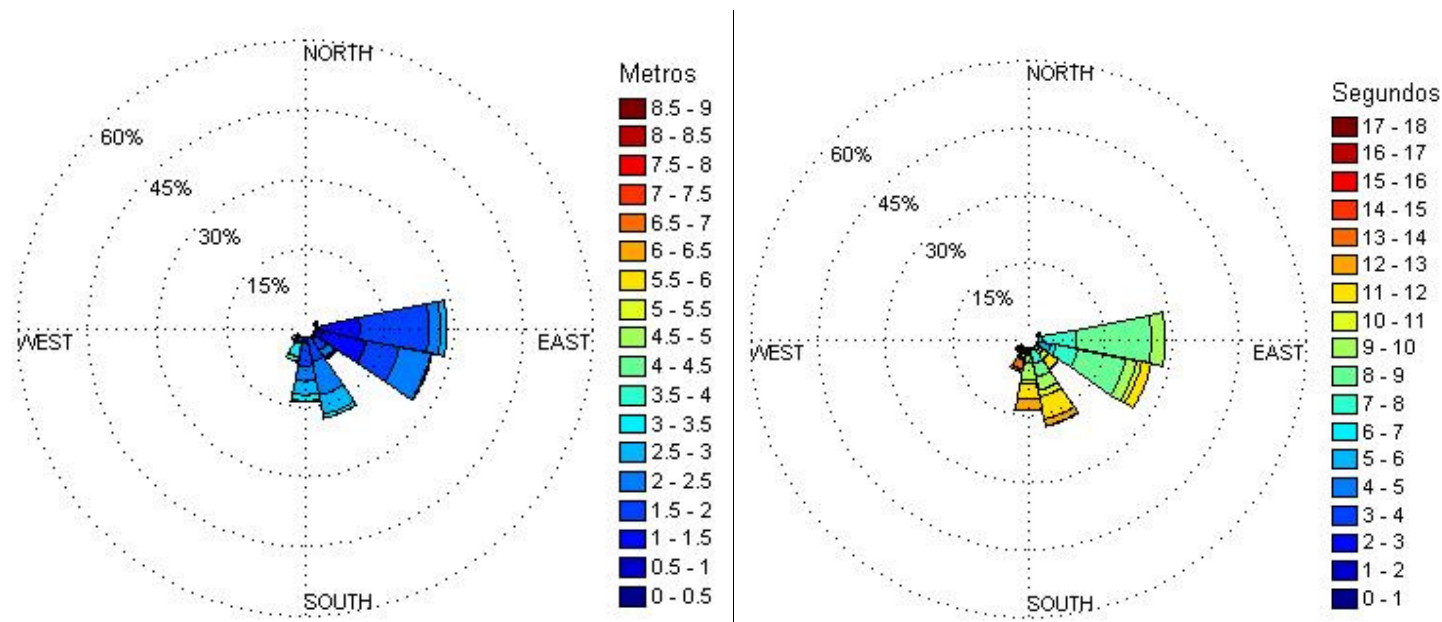

Figura 37: Rosas de Ondas para 12/2011. Gráfico da direita referente à altura de ondas por direção de propagação e gráfico da esquerda referente a período de ondas por direção de propagação, resultados em metros e segundos respectivamente.

A figura 38 demonstra os dados observados durante o mês de janeiro de 2012. As observações a cerca das direções indicam um grande predomínio dos setores E e ESE, cada um representando cerca de $27 \%$ do total das observações, somando aproximadamente $54 \%$ do total dos dados, seguidas pelas direções SSE e S com 14\% do total observado cada uma. O predomino da altura de onda com valor de $1,5 \mathrm{~m}$ voltou a preponderar, representando cerca $45 \%$ do total de ondulações observadas, também é representativa a classe de $1 \mathrm{~m}$ de altura com aproximadamente $23 \%$ do total dos dados, já o maior valor encontrado no período foi de $3,5 \mathrm{~m}$. O dados referentes aos períodos de onda tem sua maior concentração entre os valores de 7 e $8 \mathrm{~s}$, que englobam cerca de $62 \%$ da amostra em consideração, o maior período observado no mês apresentou o valor de aproximadamente $12 \mathrm{~s}$. 


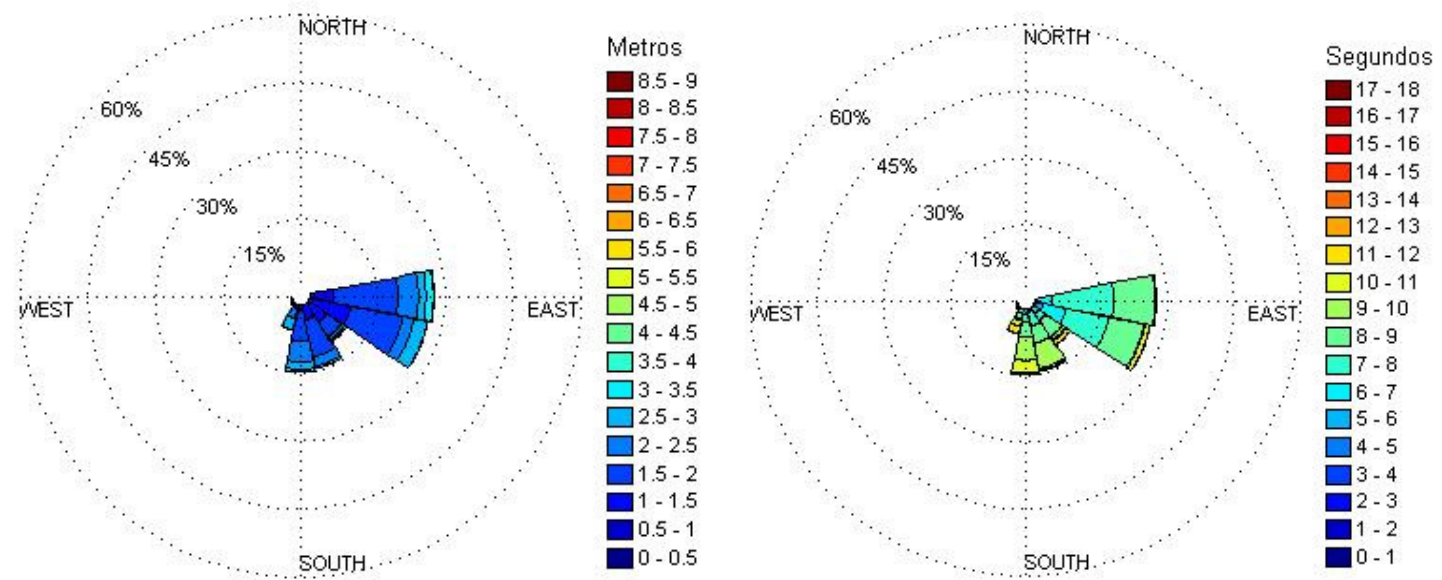

Figura 38: Rosas de Ondas para 01/2012. Gráfico da direita referente à altura de ondas por direção de propagação e gráfico da esquerda referente a período de ondas por direção de propagação, resultados em metros e segundos respectivamente.

As observações do mês de fevereiro de 2012 se encontram expostas na figura 38, e apresentam grande predomínio de ondulações provindas do setor E com aproximadamente $47 \%$ de todas as observações registradas, em seguida aparece o setor ESE com cerca $20 \%$ dos dados coletados. Em relação à altura das ondas observadas, cerca $75 \%$ do total apresentou valores entre 1 e 1,5 m, sendo o maior valor registrado de $2,7 \mathrm{~m}$. Para os dados de período predominou o intervalo entre 6 e $8 \mathrm{~s}$, com aproximadamente $67 \%$ de todas observações obtidas, sendo o valor mais frequente o de $8 \mathrm{~s}$ com $36 \%$ do total de dados, já o maior valor de período registrado no mês foi de aproximadamente $17 \mathrm{~s}$. 

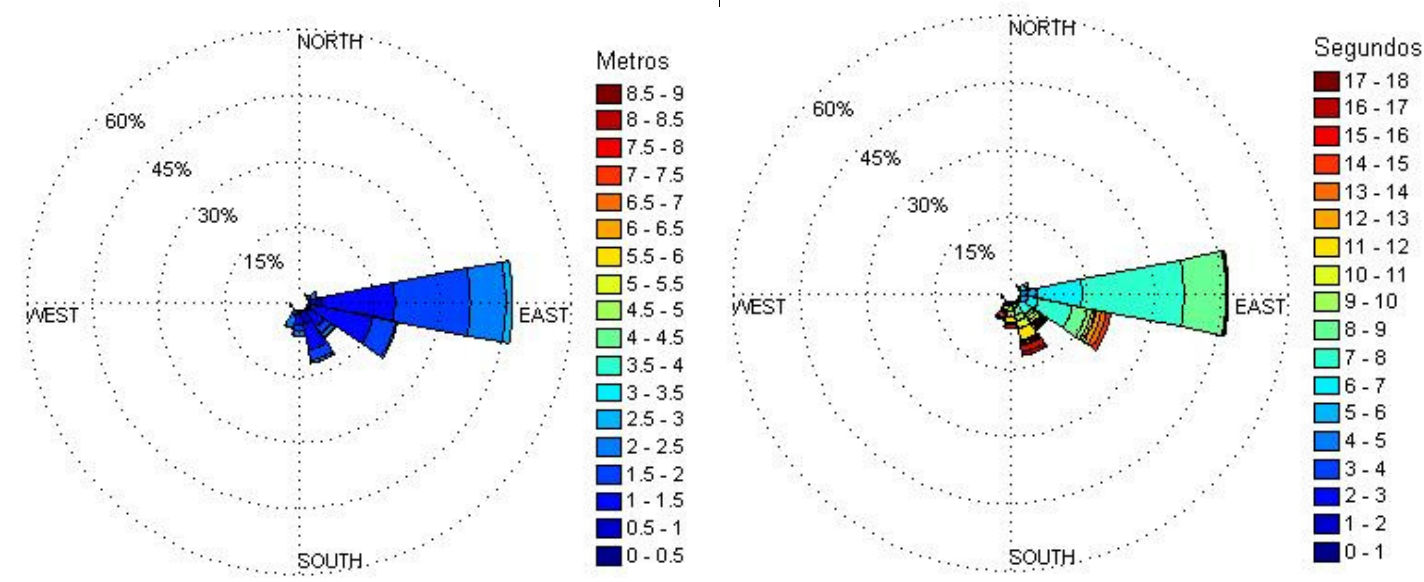

Figura 39: Rosas de Ondas para 02/2012. Gráfico da direita referente à altura de ondas por direção de propagação e gráfico da esquerda referente a período de ondas por direção de propagação, resultados em metros e segundos respectivamente.

A figura 40 demonstra os dados para o período inteiro de análise, ou seja, de 05/2011 a 02/2012. Os resultados a cerca das direções demonstram que cerca de $80 \%$ dos dados estão distribuídos no intervalo entre as direções $\mathrm{E}$ e S, sendo as maiores frequências na ordem decrescente de $21 \%$ para a direção E, $20 \%$ para direção ESE, $18 \%$ para SSE, $14 \%$ para S e $10 \%$ para SE.

Aproximadamente $92 \%$ dos registros de alturas de ondas para 0 período em questão ocorreram na faixa entre 1 e $3 \mathrm{~m}$. Os valores mais significativos foram os de 1,5 e $2 \mathrm{~m}$, ambos englobando cerca de $28 \%$ do total dos dados, em seguida aparecem os valores de 1 e 2,5 m, respectivamente com $18 \%$ e $10 \%$ dos dados registrados. De forma menos acentuada, aparecem as observações com valores na casa dos $3 \mathrm{~m}$, com $9 \%$ do total observado. A altura máxima de onda observada para o período foi de 8,6 m.

O intervalo entre 7 e 11 s englobou cerca de $81 \%$ dos dados obtidos, como o valor de $8 \mathrm{~s}$ sendo o mais frequente, totalizando $21 \%$ das observações. O segundo valor mais frequente foi de $7 \mathrm{~s}$, com $16 \%$ dos registros, seguido do valor de $9 \mathrm{~s}$ que respondeu por $13 \%$ do total. Os registros de $11 \mathrm{~s}$ responderam 
por $11 \%$ e os valores de $10 \mathrm{~s}$ somaram $10 \%$ das observações. O maior valor de período registrado na análise foi $18 \mathrm{~s}$.
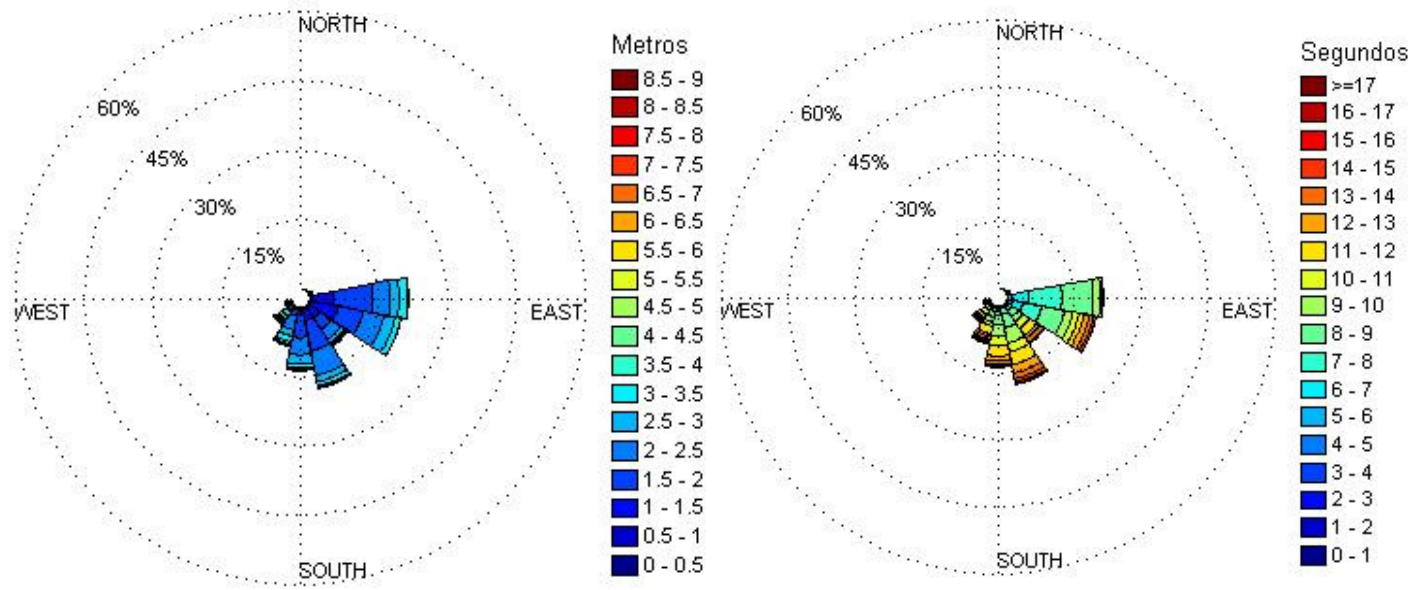

Figura 40: Rosas de Ondas para o período total analisado, ou seja, entre 05/2011 e 02/2012. Gráfico da direita referente à altura de ondas por direção de propagação e gráfico da esquerda referente a período de ondas por direção de propagação, resultados em metros e segundos respectivamente.

\subsection{3 - Precipitação}

A figura 41 apresenta a precipitação acumulada mensal para o período entre maio de 2011 de maio de 2012. De forma geral, os primeiros meses da série, maio, junho, julho e agosto de 2011 apresentaram pequenas variações no volume de chuva, variando em torno dos $100 \mathrm{~mm}$ mensais, com um leve aumento no mês de julho, que acumulou 158,9 mm de chuva.

Em setembro houve uma queda brusca, quando o total de precipitação alcançou somente $28,9 \mathrm{~mm}$. A partir de outubro pode se observar uma tendência de aumento na quantidade de chuvas, com os meses do verão apresentando o maior volume de precipitação. O mês com a maior precipitação foi o de janeiro de 2012, com 293,6 mm, seguido dos meses de dezembro de 
2011 e fevereiro de 2011, que apresentaram 216,2 e 210,7 mm respectivamente.

Com a chegada do fim da estação quente configurou-se uma queda na quantidade de chuvas, inicialmente pequena, comprovada pelos 198 e 192,9 $\mathrm{mm}$ acumulados nos meses de março e abril respectivamente, e mais aparente no mês de maio de 2012, apresentando 149 mm, já representando o regime de chuvas das estações mais frias e secas.

\section{Precipitação Mensal entre 05/2011 e 02/2012}

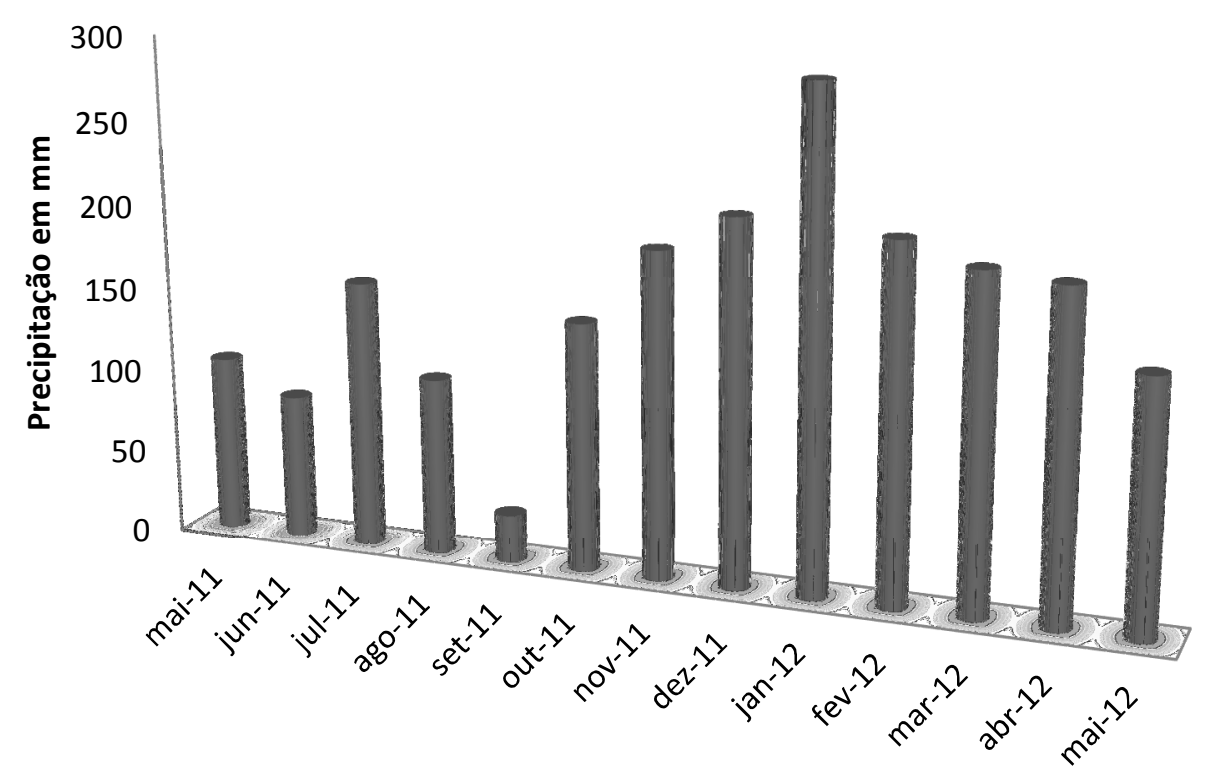

Figura 41: Precipitação acumulada mensal no período entre 05/2011 e 05/2012. Valores em $\mathrm{mm}$.

As figuras 42 a 48 demonstram os gráficos criados para caracterizar a precipitação no período entre as saídas a campo. A figura 42 apresenta os resultados para o período entre 02/06/11 e 26/07/11, a coleta do mês de junho aconteceu entre os dias 02 e 10, já a coleta do mês de julho aconteceu entre os dias 19 e 26. As máximas precipitações aconteceram nos dias 03/07 (43,6 
$\mathrm{mm}$ ) e 09/06 (36,8 mm), estando este dia no período de coleta do mês de junho. Durante a coleta do mês de julho não ocorreram fortes precipitações, com o máximo no dia 22/07 com 2,5 mm de chuva. $O$ total de precipitação acumulado no período foi de $144,8 \mathrm{~mm}$.

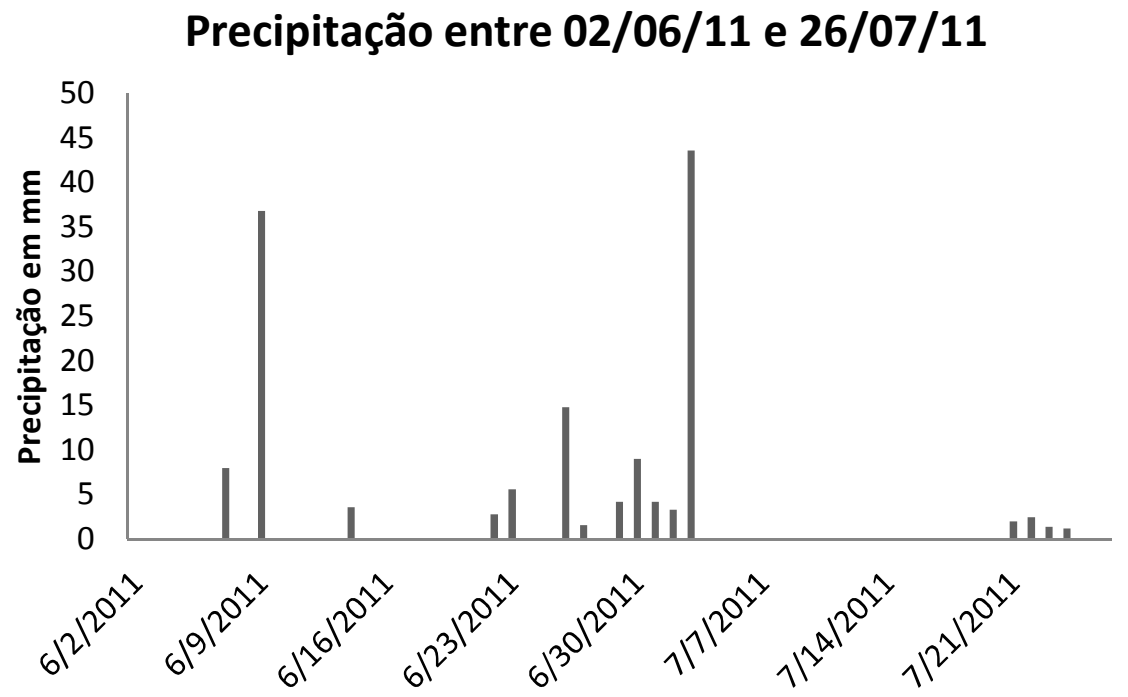

Figura 42: Precipitação diária no período entre 02/06/2011 e 26/07/2011. Valores em mm.

$\mathrm{Na}$ figura 43 são apresentados os dados referentes ao período entre 26/07/2011 e 12/08/2011. Segundo a Síntese Sinótica Mensal do CPTEC, nesta época houve grandes enchentes no Vale do Ribeira, com municípios chegando a acumular $100 \mathrm{~mm}$ de chuva em um só dia. O máximo de precipitação se concentrou entre o final do mês de julho e começo do mês de agosto, com o dia mais chuvoso apresentando $44,5 \mathrm{~mm}$ (31/07), seguido do dia 01/08 com 38,3 mm e 30/07 com $19 \mathrm{~mm}$. O restante do período não apresentou grandes precipitações e no dia da coleta de agosto (12), não houve registro de chuvas. O total de precipitação do período foi de 118,2 mm. 


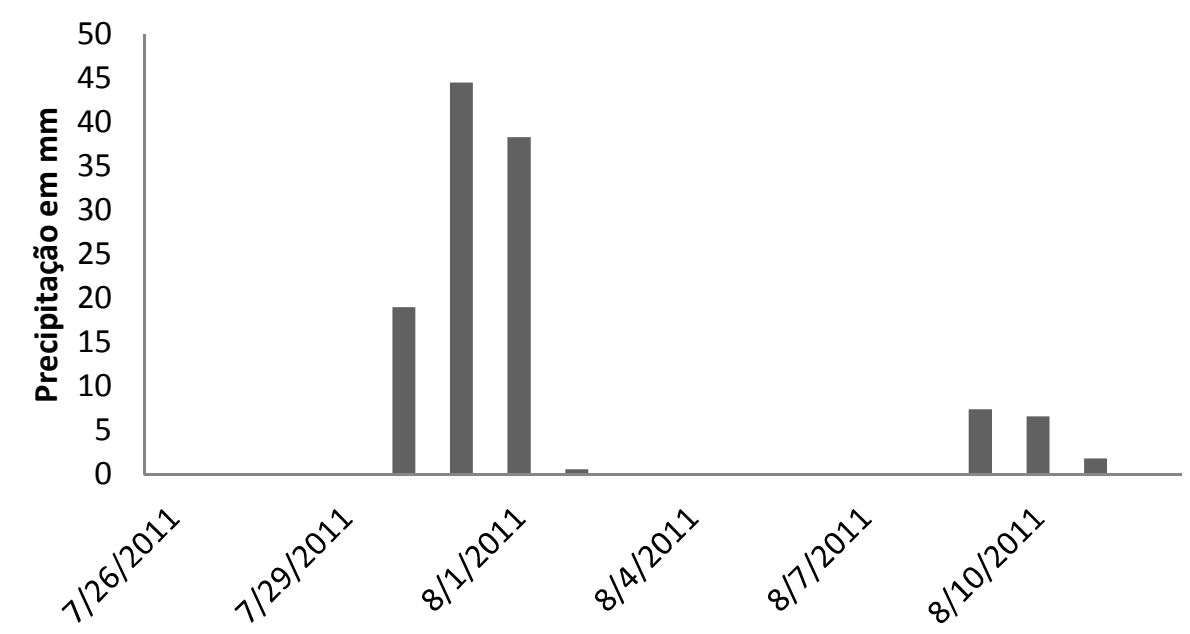

Figura 43: Precipitação diária no período entre 26/07/2011 e 12/08/2011. Valores em mm.

Os dados para o período entre 12/08/11 e 30/09/11 estão dispostos na figura 44, o intervalo em questão apresentou os menores valores de precipitação entre os períodos de coleta, totalizando somente $80 \mathrm{~mm}$. Os máximos do período aconteceram nos dias 19/08, 22/08 e 15/09, apresentando respectivamente $10,6,11$ e $9,6 \mathrm{~mm}$. Durante a coleta de setembro, entre os dias 27 a 30, não houve registro de precipitação.

\section{Precipitação entre 12/08/11 e 30/09/11}

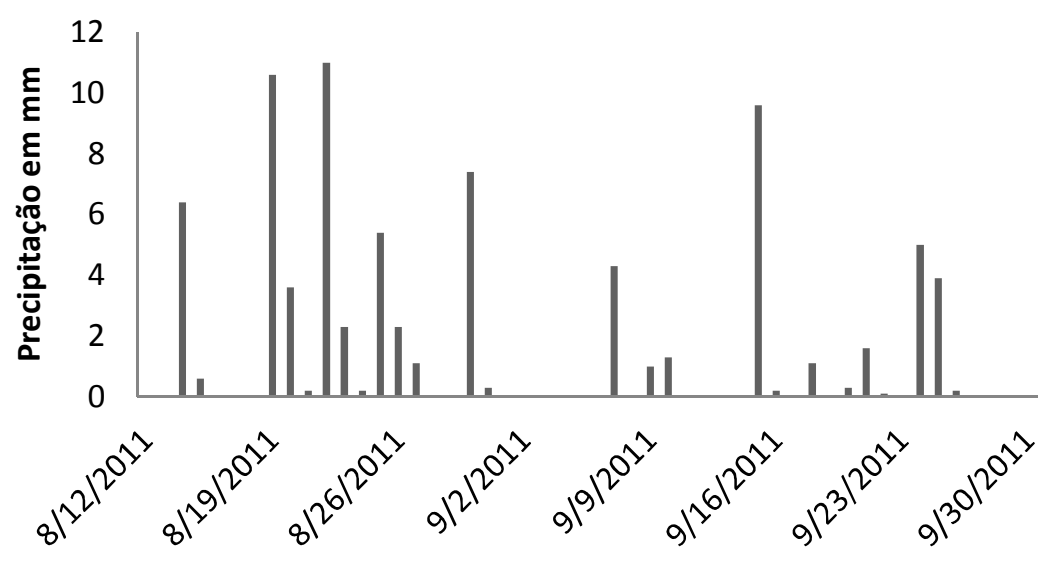

Figura 44: Precipitação diária no período entre 12/08/2011 e 30/09/2011. Valores em mm. 
A figura 45 expõem os registros de chuva para o período entre 30/09/11 e 25/11/11. Os máximos do período aconteceram nos dia 15/10, 14/11 e 15/11, apresentando respectivamente $32,1,47,7$ e 47,8 mm. Nos dias 21 a 25 de novembro, quando aconteceu a coleta mensal, foram registrados $0,2 \mathrm{~mm}$ de chuva no dia 21 e $8,8 \mathrm{~mm}$ no dia 22 . O total de precipitação para o intervalo em questão foi de $315,7 \mathrm{~mm}$, valor aparentemente elevado devido ao grande espaçamento entre as coletas.

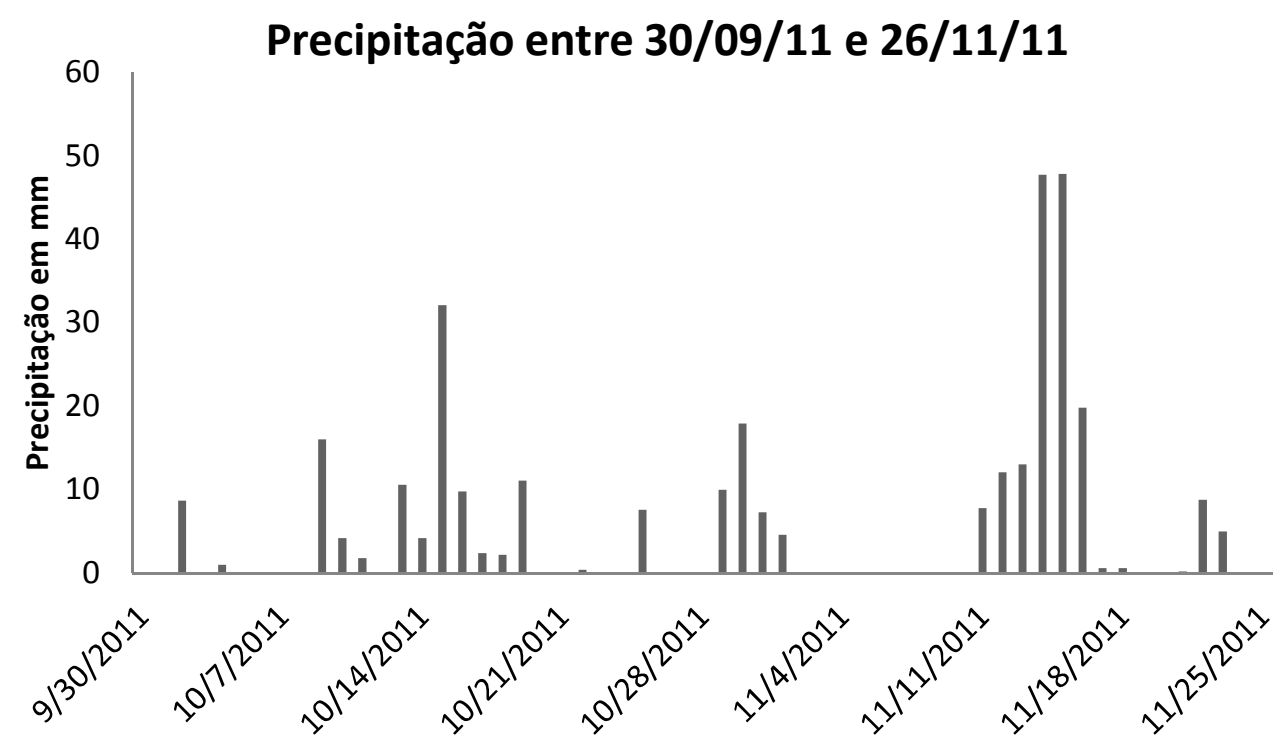

Figura 45: Precipitação diária no período entre 30/09/2011 e 25/11/2011. Valores em mm.

Os dados para o intervalo entre 25/11/11 e 15/12/11 estão representados na figura 46. O máximo de precipitação ocorreu durante a saída a campo, entre 12 e 15 de dezembro, justamente no último dia, totalizando 52,2 $\mathrm{mm}$ de chuva. Porém durante o restante do intervalo os valores de precipitação não chegaram a $20 \mathrm{~mm}$ diários. Apesar de este intervalo ser curto, o grande volume de chuva que caiu no dia $15 / 12$ acarretou o acumulado total 
relativamente alto, com 138,2 $\mathrm{mm}$.

Precipitação entre 25/11/11 e 15/12/11

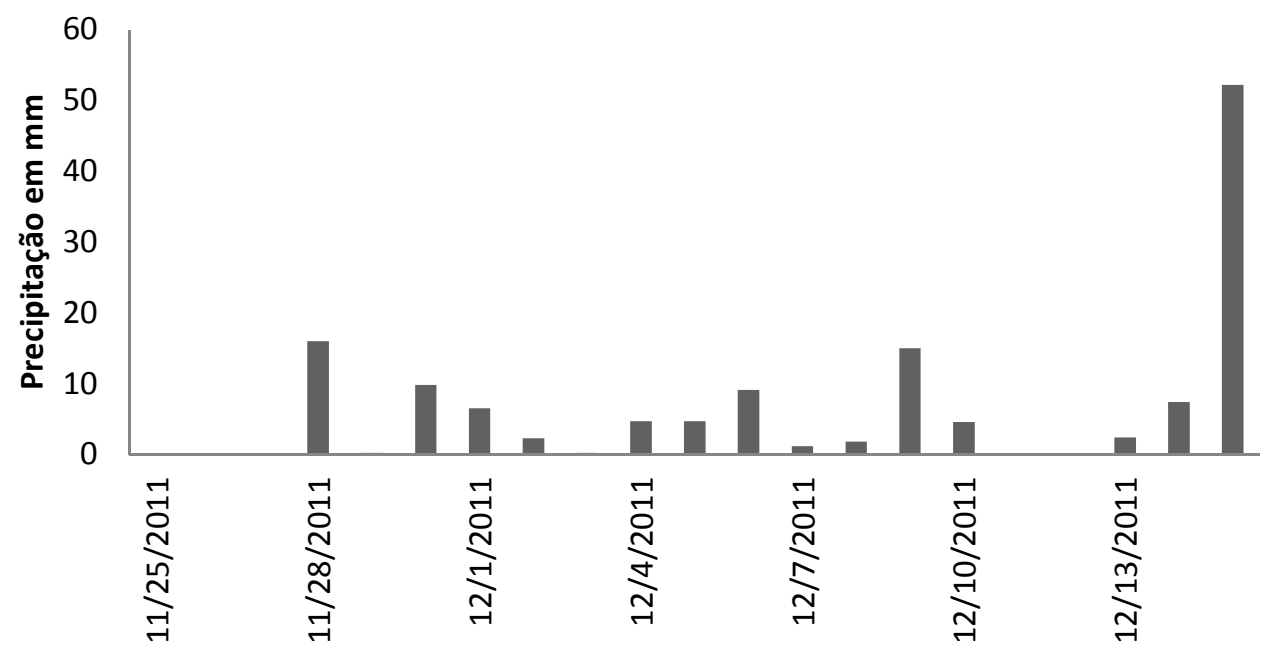

Figura 46: Precipitação diária no período entre 25/11/2011 e 15/12/2011. Valores em mm.

A figura 47 apresenta os dados referentes ao período entre 15/12/11 e 30/01/12, como já exposto, estes meses apresentaram os mais altos índices de precipitação apresentando o maior valor acumulado de precipitação: 449,8 mm. O máximo de precipitação aconteceu no dia $25 / 01$ somando $86,3 \mathrm{~mm}$, também são significativos os dias 31/12 e 26/01, apresentando valores de 55,1 e 64 mm respectivamente. Durante a coleta de janeiro, entre os dias 27 e 30, não aconteceram registros significativos, com o dia 27 apresentado $7,8 \mathrm{~mm}$ e 0 dia $2812,9 \mathrm{~mm}$. 
Precipitação entre 15/12/11 e 30/01/12

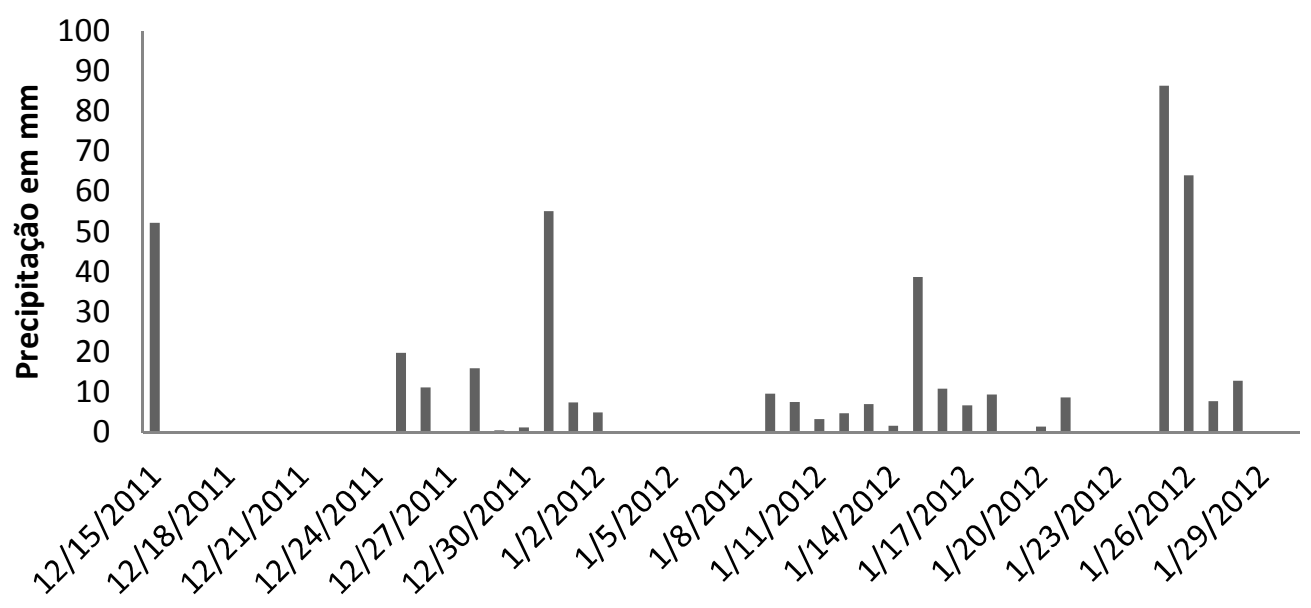

Figura 47: Precipitação diária no período entre 15/12/2011 e 30/01/2012. Valores em mm.

Os dados referentes ao período entre os dias 31/01/12 e 27/02/12 estão representados na figura 48 . O máximo de precipitação registrado no período foi de $87,4 \mathrm{~mm}$ no dia 13/02, sendo este o valor máximo diário do período analisado. Durante os dias 24 a 27 de fevereiro, quando aconteceu a coleta mensal, não acorreram chuvas significativas, com observações de 2,7 $\mathrm{mm}$ para o dia 24 e $6,2 \mathrm{~mm}$ para o dia 27 . O total de precipitação acumulado para o intervalo foi de $143,8 \mathrm{~mm}$. 


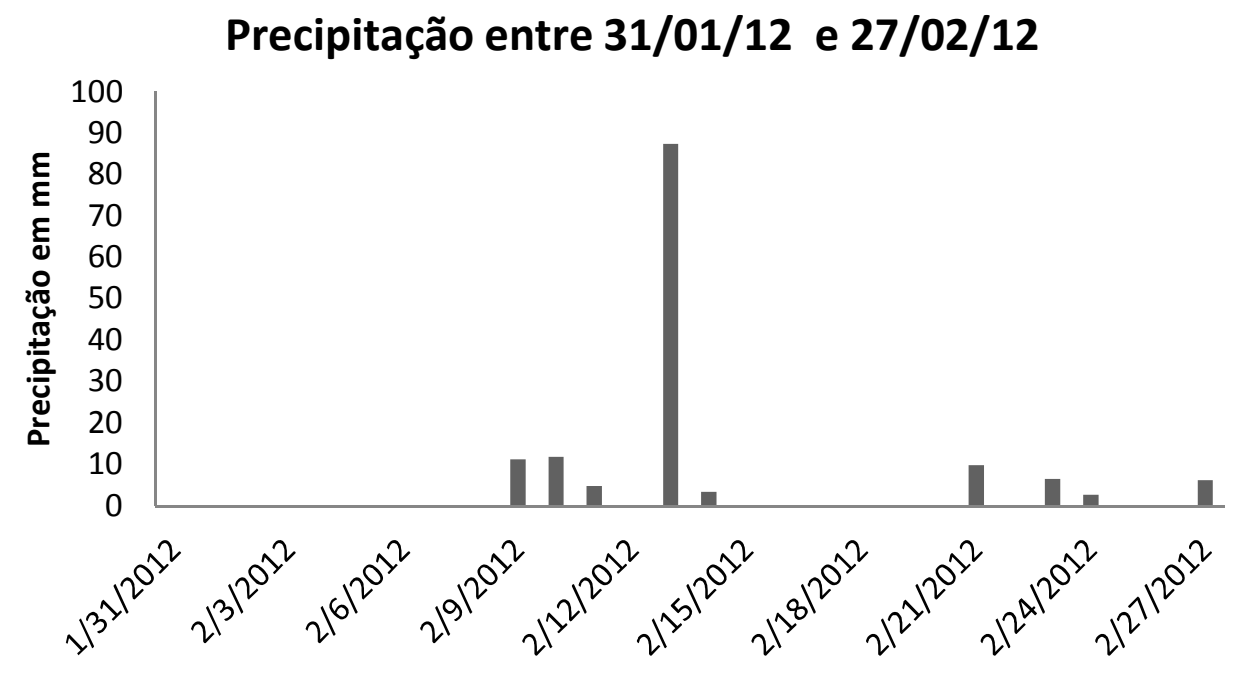

Figura 48: Precipitação diária no período entre 30/01/2012 e 27/02/2012. Valores em mm.

\section{2 - Análises das Linhas de Costa Pretéritas}

Na figura 17 estão dispostas as linhas de costa obtidas através da análise das fotografias aéreas e imagens de satélite. As linhas se encontram sobre a fotografia feita em 2001. Deve se salientar que as linhas de costa foram traçadas no limite entre a faixa de areia e o início da vegetação. 


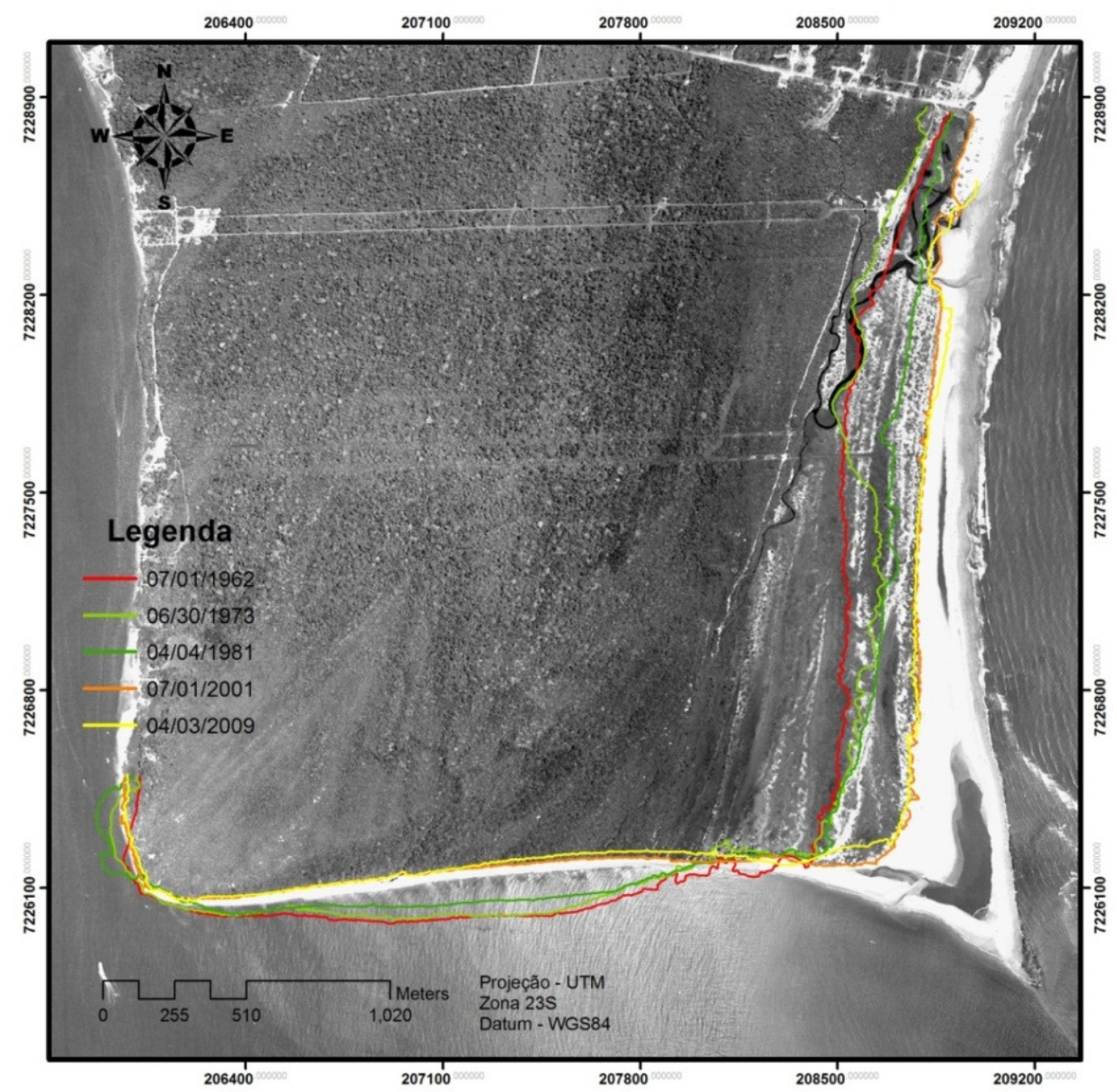

Figura 49: Linhas de costa obtidas a partir das fotografias aéreas e imagens de satélite sobrepostas a fotografia aérea de 2001.

O processo de georreferenciamento de fotos aéreas sempre exibe erros de posicionamento devido aos efeitos de distorção associados á obtenção das destas. Em áreas com poucas construções ou feições rochosas, como a área de estudo em questão, o erro agregado é maior devido à falta de pontos confiáveis para correlação entre as diferentes imagens, especialmente para as fotos antigas.

O método utilizado pela extensão DSAS leva em consideração tais erros em forma de um parâmetro para o cálculo da taxa de variação da linha de costa (TVLC) , sendo o próprio usuário o definidor de tal parâmetro. No presente estudo optou-se por utilizar o RMS, Erro Quadrado Médio (Root 
Square Mean), fornecido pelo SIG $\operatorname{ArcGIS}^{\circledR}$ no processo de georreferenciamento das imagens, admitindo-se a fotografia de 2001 como referência. A tabela 6 expõe os erros utilizados, porém deve se levar em consideração que valores podem estar subestimados para as fotos de $1962 \mathrm{e}$ 1973 por conta da dificuldade de se encontrar pontos comuns na fotografia de 2001 e pela escala das fotos serem maiores que o aconselhável (Moore, 2000).

\begin{tabular}{rr}
\hline Fotografias & \multicolumn{1}{c}{ RMS } \\
\hline $07 / 01 / 1962$ & 2.14 \\
$06 / 30 / 1973$ & 2.51 \\
$04 / 04 / 1981$ & 1.87 \\
$07 / 01 / 2001$ & 0 \\
$04 / 03 / 2009$ & 1.17 \\
$04 / 03 / 2009$ & 1.62 \\
$04 / 03 / 2009$ & 1.41 \\
$04 / 03 / 2009$ & 1.64 \\
$04 / 03 / 2009$ & 1.64
\end{tabular}

Tabela 3: Valores de RMS utilizados na aplicação da extensão DSAS.

A extensão DSAS se utiliza de transectos que partem de uma linha base para interceptar as linhas costa definas pelo usuário. A partir dos pontos interceptados pelos transectos é calculada a distância da linha base e ao dividir os resultados pelos anos entre as linhas de costa obtém-se a TVLc em m/anos. $\mathrm{Na}$ figura 50 encontram-se os 177 transectos gerados no estudo e as linhas de costa dos anos de 1962 e 1973. 


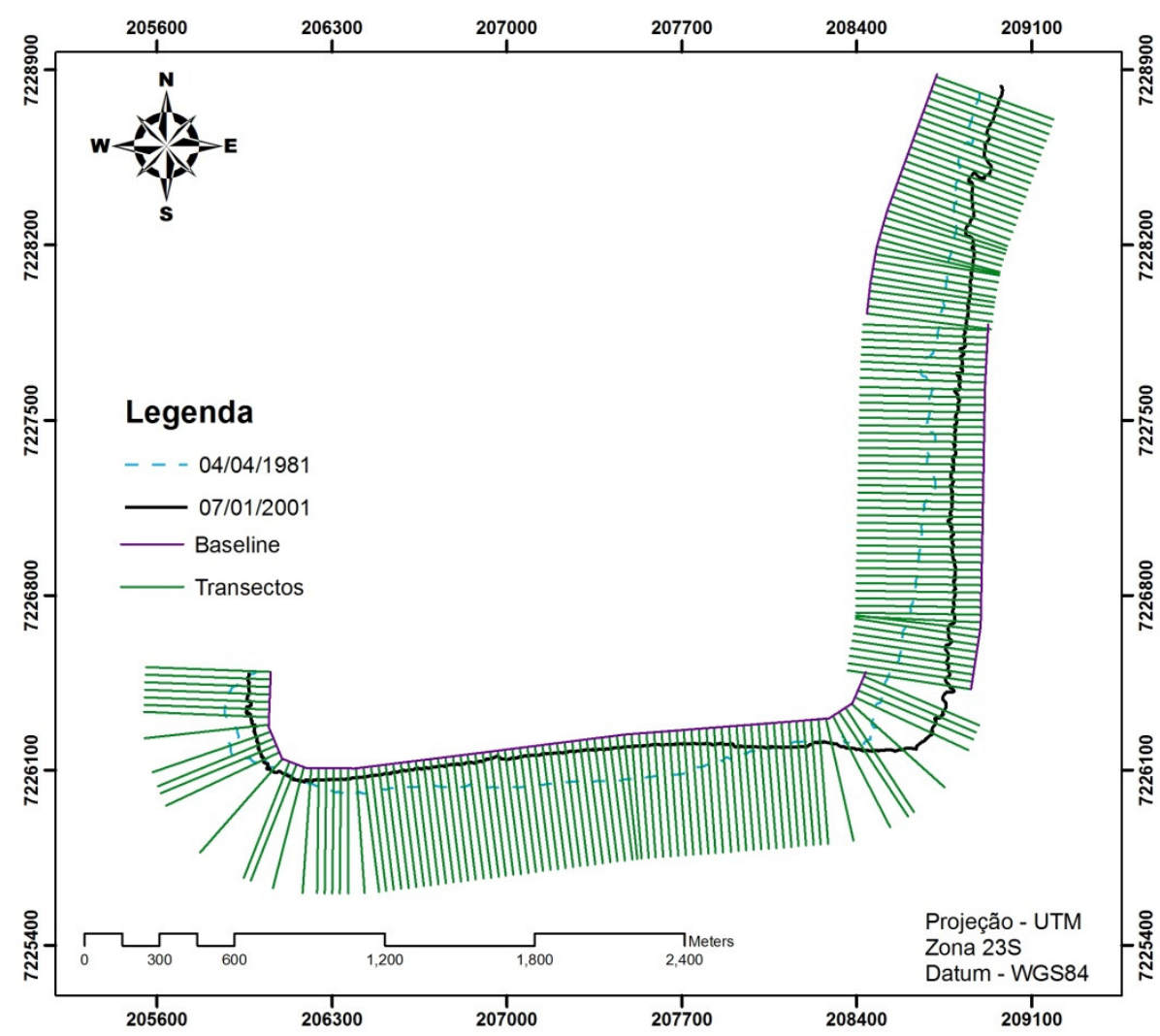

Figura 50: Transectos gerados para o calculo da TVLc e linhas de costa de 1981 (linha azul pontilhada) e 2001 (linha cheia preta).

A fim de se facilitar a compreensão dos resultados, a área de estudo foi dividida em três setores distintos apresentados na figura 51 .

- Setor 1: Localizado na sudoeste da imagem, compreende a chamada Ponta da Trincheira.

- Setor 2: Compreende a faixa arenosa entre as curvas fisiográficas de Ilha Comprida, margeando o canal de maré da desembocadura de Cananéia.

- Setor 3: Com início no Pontal de Fora, abrange a face exposta a ação direta do oceano, tratando-se de fato da faixa praial da llha Comprida. 


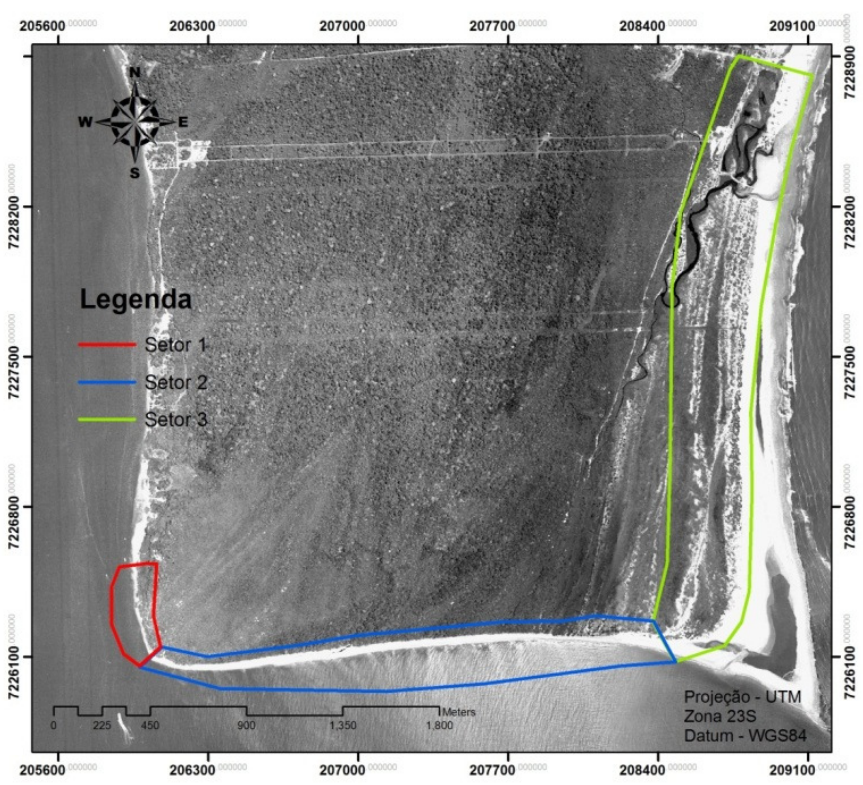

Figura 51: Setores adotados para facilitar a exposição dos resultados. Setor 1 Vermelho, Setor 2 - Azul; Setor 3 - Verde.

A figura 52 apresenta os resultados da TVLc entre os anos de 1962 e 1973. O Setor 1 apresenta valores de TVLc entre 0 e 7,63 m/ano; no Setor 2 ocorreu erosão com valores de TVLc entre $-8,77$ e -3.43 m/ano, de forma mais acentuada nas áreas adjacentes a curva da desembocadura; e o Setor 3 apresentou as maiores taxas de acresção, com valores de TVLc entre 0 e 11,97 m/ano. Entretanto, em sua porção localizada mais norte houve uma erosão significativa com valores de TVLc entre $-8,77$ e $-3,51 \mathrm{~m} / \mathrm{ano}$. 


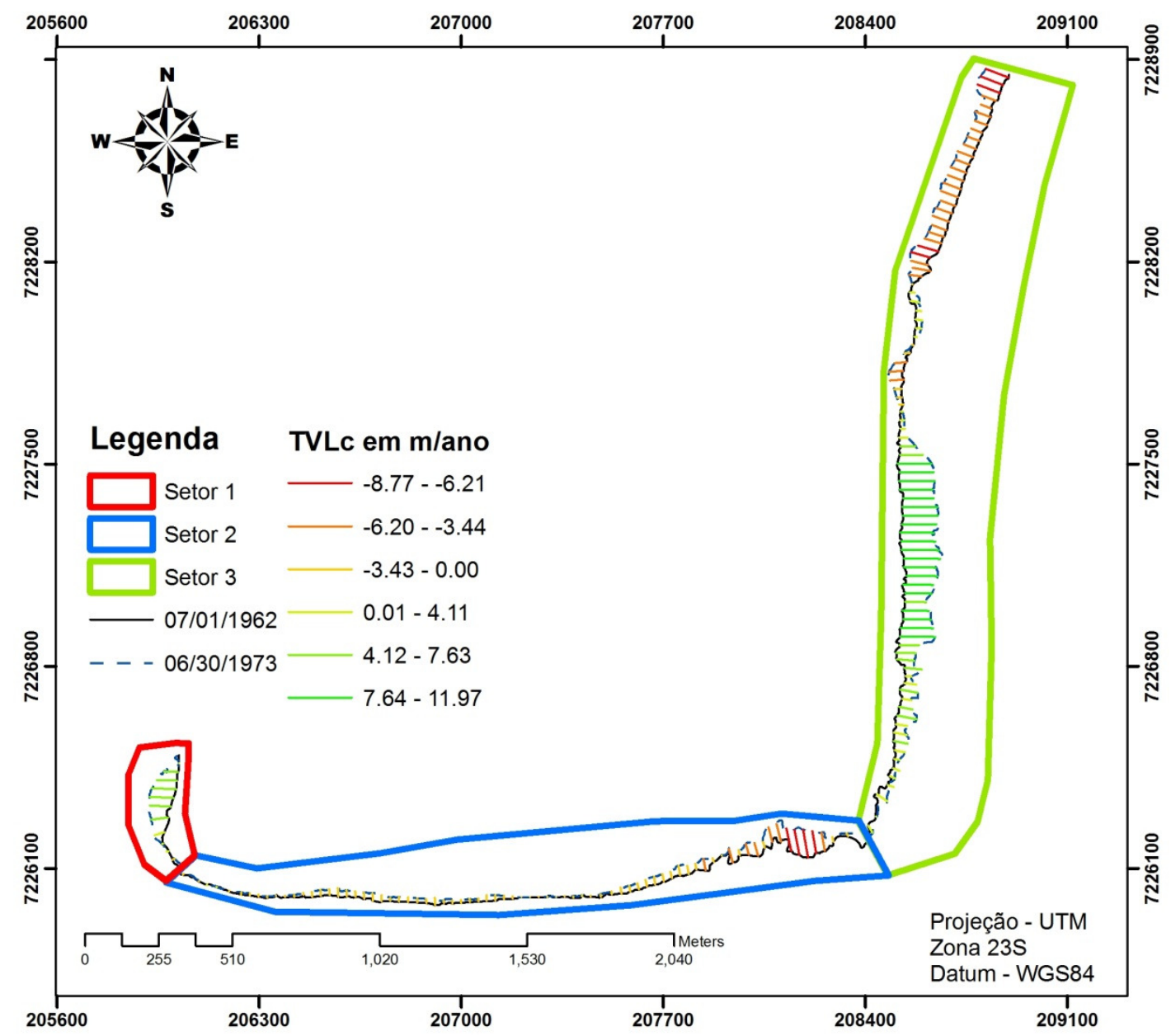

Figura 52: Resultados do cálculo da TVLc entre os anos de 1962 e 1973, valores em m/ano.

A figura 53 ilustra os resultados do cálculo da TVLc entre os anos de 1973 e 1981. O Setor 1 continuou a apresentar acresção, mantendo praticamente os mesmos valores de TVLc, variando entre 0 e 7,42 m/ano. 0 Setor 2 apresentou uma inversão nas áreas próximas a curva da desembocadura, onde a linha de costa havia recuado, ocorrendo desta vez uma pequena acresção, com valores de TVLc entre 0 e 3,17 m/ano. Contudo, nas áreas mais interiores ocorreu a intensificação do processo erosivo, expressada com valores máximos de TVLc na casa de $-7,42 \mathrm{~m} / \mathrm{ano}$. O Setor 3 apresentou acresção em toda sua extensão, com os valores de TVLc aumentando rumo ao norte, variando entre 0 e 23,17 m/ano. 


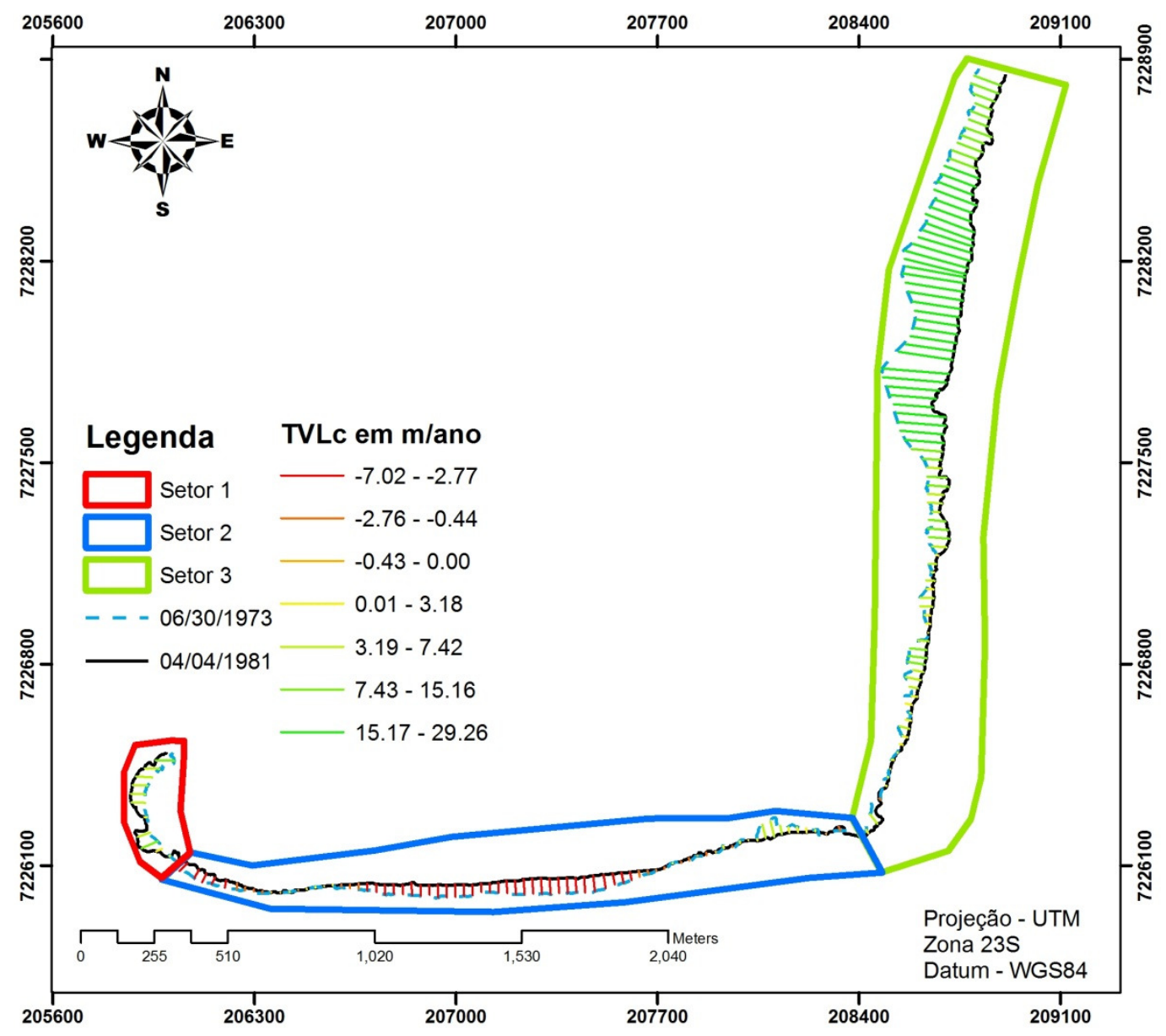

Figura 53: Resultados do cálculo de TVLc para período entre 1973 e 1981, valores expressos em m/ano.

Os resultados para o período entre 1981 e 2001 estão expressos na figura 54, notar que este período apresenta o maior espaçamento entre as fotografias analisadas, somando 20 anos contra aproximadamente 10 anos dos outros períodos. No Setor 1 ocorreu uma inversão de tendências, apresentando agora uma erosão pronunciada com valores de TVLc entre -2,54 e -6,48 m/ano. O Setor 2 manteve a tendência de erosão acentuada nas áreas interiores com valores de TVLc entre 0 e $-6,48$ m/ano, enquanto a porção próxima a curva da desembocadura se mostrou praticamente estável, com valores de TVLc de até $2,54 \mathrm{~m} / \mathrm{ano}$. O Setor 3 também repetiu a tendência de acresção, porém de forma mais intensa na área mais ao sul, próxima a curva fisiografica, 
apresentando valores de TVLc entre 2,59 e 12,72 m/ano.

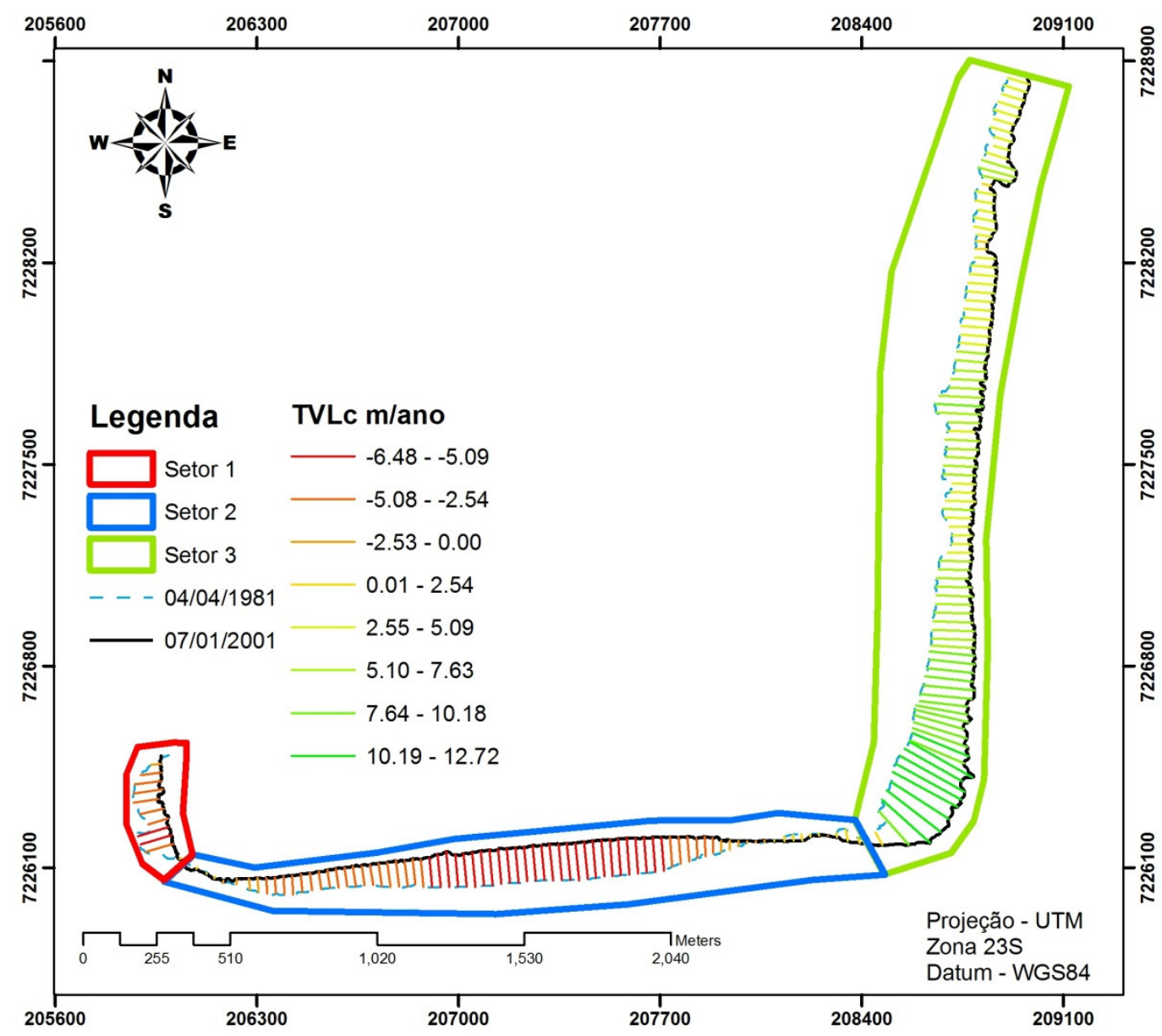

Figura 54: Resultados do cálculo de TVLc para período entre 1981 e 2001, valores expressos em m/ano.

$\mathrm{Na}$ figura 55 estão expressos os resultados para o período entre 2001 e 2009. Esta comparação indica resultados que apresentam a menor variação dos valores de TVLc, tal fato pode estar ligado ao pequeno espaçamento entre duas imagens analisadas, totalizando 8 anos, correspondendo ao período decorrido entre 1973 e 1981.

O Setor 1 continua apresentando recuo da linha de costa porém de forma menos intensa, com valores de TVLc entre $-4,0$ e 0 m/ano. Já o Setor 2 manteve a tendência erosiva, apresentando uma intensificação do recuo da 
linha de costa de oeste para leste, com valores TVLc entre 0 e -6,34 m/ano. No entanto, a área localizada no extremo leste demonstrou uma tendência acresciva com valores de TVLc entre 3,1 e 5,47 m/ano. O Setor 3 se manteve praticamente estável em sua zona mais central com valores de TVLc entre 0,71 a 4,98 m/ano. Em sua porção mais próxima a curva da desembocadura houve um recuo considerável da linha de costa, representados pelos valores mais negativos de TVLc deste período (entre -4 e $-8,75$ m/ano). Na sua área mais ao norte há alternância entre recuo e avanço da linha de costa, com variação da TVLc entre -8,75 e 10,21 m/ano.

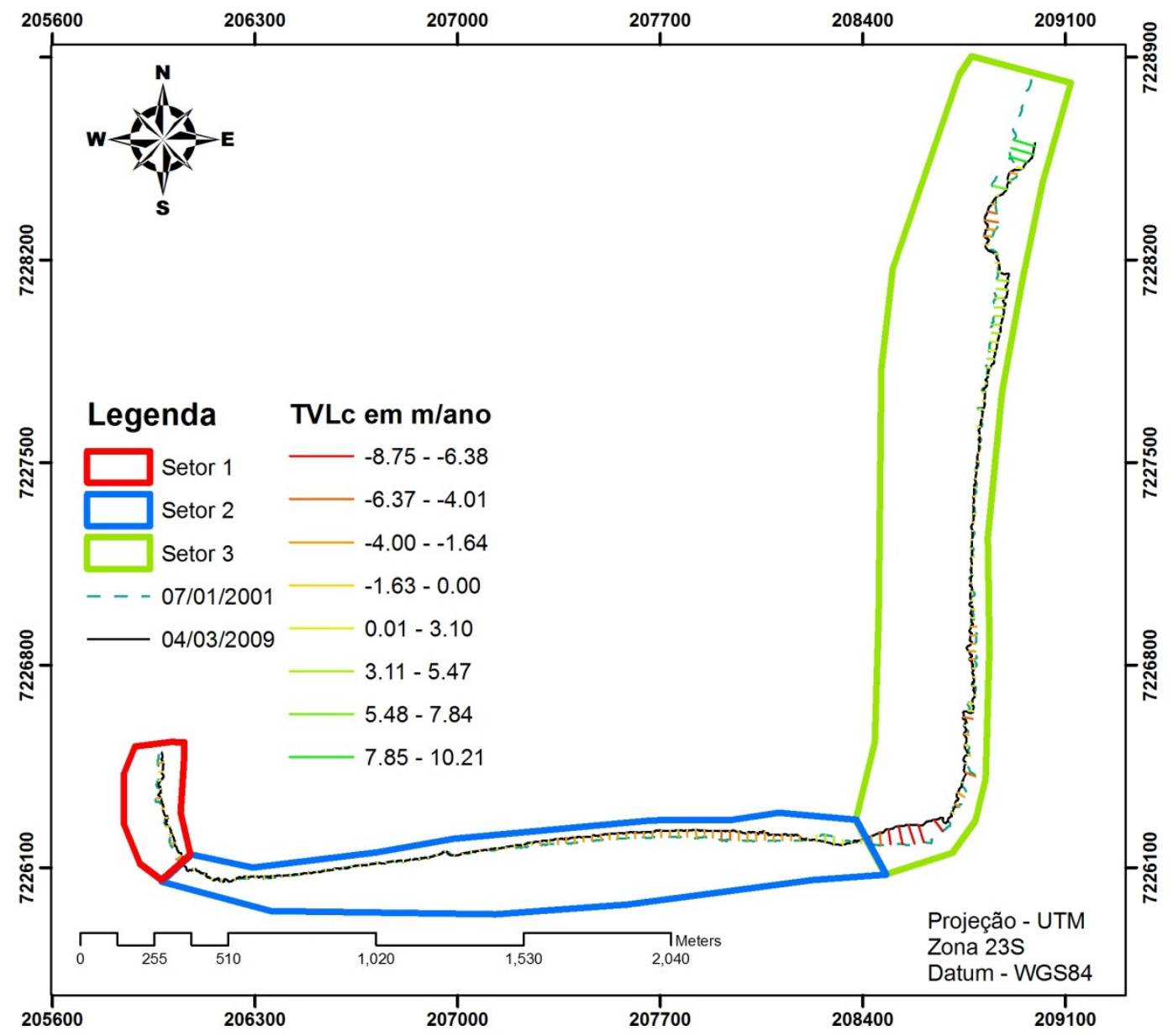

Figura 55: Resultados do cálculo de TVLc para período entre 2001e 2009, valores expressos em m/ano. 
A figura 56 apresenta os resultados para o período total de análise, ou seja, entre 1962 e 2009. O Setor 1 apresenta duas tendências distintas, exibindo acresção em sua porção mais ao norte, com valores de TVLc na faixa de 2,29 e 4,94 m/ano, e erosão em sua porção mais ao sul, com valores próximos a $-2,75 \mathrm{~m} / \mathrm{ano}$. O Setor 2 apresenta uma tendência de forte recuo da linha de costa por toda sua extensão com valores de TVLc entre $-2,75$ e $-4,44$ m/ano, sendo os valores mais negativos localizados na zona mais central. A única exceção desta tendência se encontra em uma pequena área próxima a desembocadura de Cananéia que se mantém quase estável com valor de TVLc entre $-0,83$ e 3,37 m/ano. O Setor 3 apresentou uma tendência de avanço da linha de costa em toda sua extensão, com valores de TVLc entre 2,29 e 7,27 m/ano, área com maior avanço foi a porção central e a com menor avanço a porção localizada mais ao norte. 


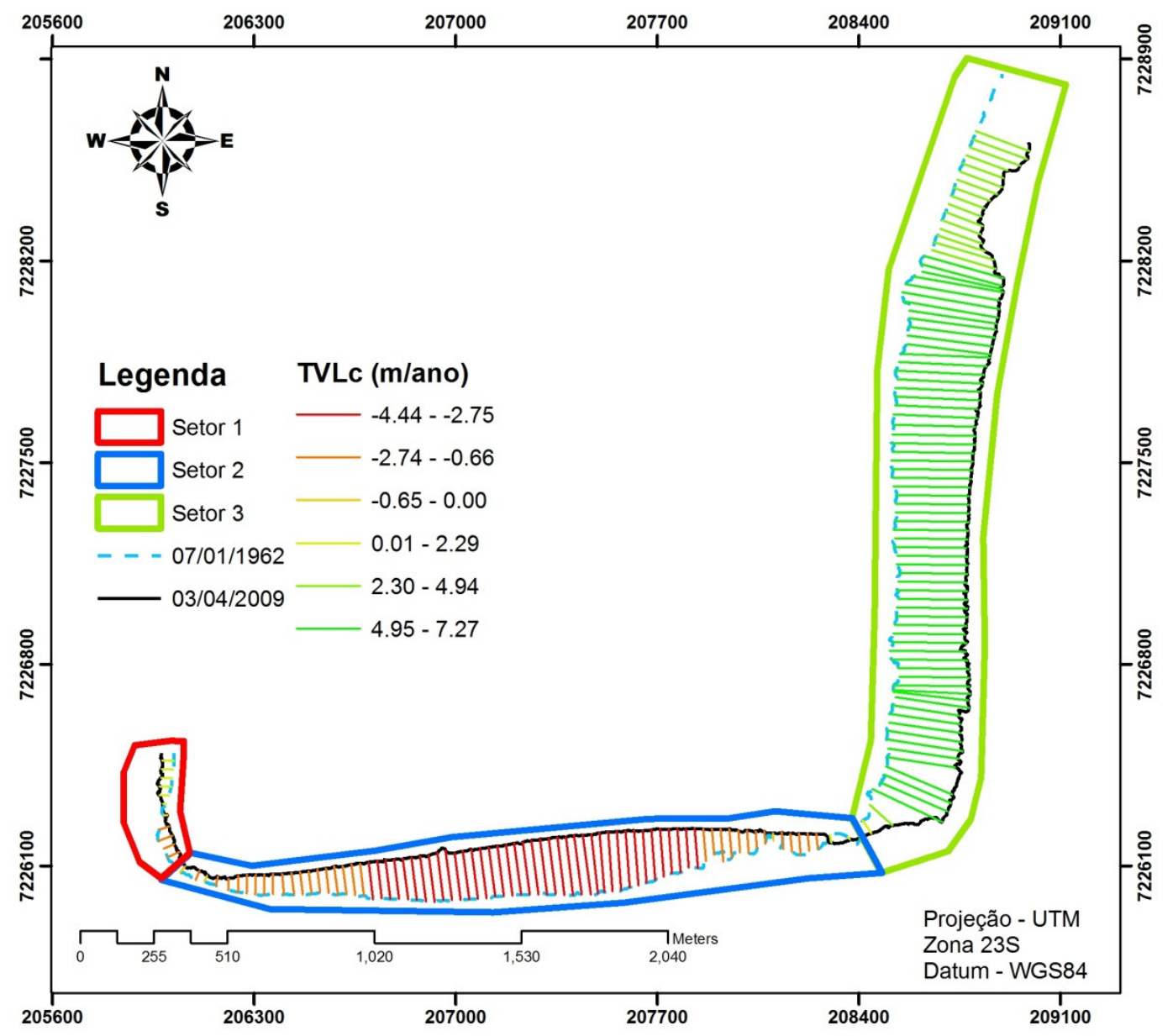

Figura 56: Resultados do cálculo de TVLc para período entre 1962 e 2009, valores expressos em m/ano.

A tabela 4 demonstra os valores de variação máximos e mínimos obtidos para cada período tanto em taxas anuais (TVLc), quanto no acumulado total. Os resultados obtidos para todos os transectos estão demonstrados no Anexo II.

Os valores da tabela resumem a descrição apresentada, com o Setor 1 demonstrando uma tendência acrescional nos dois primeiros períodos em face a tendência erosiva apresentada no dois últimos. O Setor 2 quase sempre exibe os menores valores de TVLc e totais, caracterizando uma zona com perda sedimentar. Já o Setor 3 apresenta sempre os maiores valores de TVLc e também acumulados, demonstrando sua tendência de ganho de terreno. 
Fato interessante de se ressaltar é a ocorrência dos menores valores, tanto de TVLc quanto acumulados, no Setor 3 durante o período entre 2001 e 2009.

\begin{tabular}{|c|c|c|c|c|c|c|c|c|c|c|c|}
\hline & $\begin{array}{r}1962 \\
\text { TVLc } \mathrm{m} / \mathrm{an}\end{array}$ & $\begin{array}{l}1973 \\
\text { TVLc tot }\end{array}$ & $\begin{array}{r}1973 \text { a } \\
\text { TVLc m/ano }\end{array}$ & $\begin{array}{l}1981 \\
\text { TVLc tot }\end{array}$ & $\begin{array}{r}1981 \text { a } 2 \\
\text { TVLc } \mathrm{m} / \text { ano }\end{array}$ & $\begin{array}{l}2001 \\
\text { TVLc tot }\end{array}$ & $\begin{array}{r}2001 \mathrm{a} \\
\text { TVLc } \mathrm{m} / \mathrm{ano}\end{array}$ & $\begin{array}{l}2009 \\
\text { TVLc tot }\end{array}$ & $\begin{array}{r}1963 \text { a } \\
\text { TVLc m/ano }\end{array}$ & $\begin{array}{l}2009 \\
\text { TVLc tot }\end{array}$ & \\
\hline Máx & 7.63 & 83.93 & 8.28 & 66.24 & 0.33 & 6.6 & 0.1 & 0.8 & 0.9 & 41.4 & \multirow{2}{*}{ Setor 1} \\
\hline Min & -0.73 & -8.03 & 0.38 & 3.04 & -5.55 & -111 & -2.19 & -17.52 & -1.12 & -51.52 & \\
\hline Máx & 0.33 & 3.63 & 7.21 & 57.68 & 2.08 & 41.6 & 3.58 & 28.64 & 0.57 & 26.22 & \multirow{2}{*}{ Setor 2} \\
\hline Mín & -8.77 & -96.47 & -7.02 & -56.16 & -6.48 & -129.6 & -4.36 & -34.88 & -4.44 & -204.24 & \\
\hline Máx & 11.97 & 131.67 & 23.17 & 185.36 & 12.72 & 254.4 & 10.21 & 81.68 & 7.27 & 334.42 & \multirow{2}{*}{ Setor 3} \\
\hline Min & -7.79 & -85.69 & -0.94 & -7.52 & 0 & 0 & -8.75 & -70 & 0 & 0 & \\
\hline
\end{tabular}

Tabela 4: Valores máximos e mínimos da variação da linha costa nos períodos analisados. A coluna da esquerda representa a variação em metros por ano (TVLc m/ano), e a coluna da direita representa a variação total em metros (TVLc tot).

Analisando a tabela notam-se as maiores taxas de variação anuais ocorrendo no período entre 1973 e 1981 no Setor 3 (23,17 m/ano). Estas variações ocorreram em uma área mais ao norte, onde está localizado um rio que influenciou localmente a variação da linha de costa, como pode ser observado na figura 57. Devido à baixa qualidade da fotografia de 1973 e também ao fato da vegetação adjacente ao curso do rio se encontrar em processo de fixação no período em questão, deve-se agregar uma incerteza extra na definição da linha de costa, portanto os valores para esta seção provavelmente se encontram superestimados. 


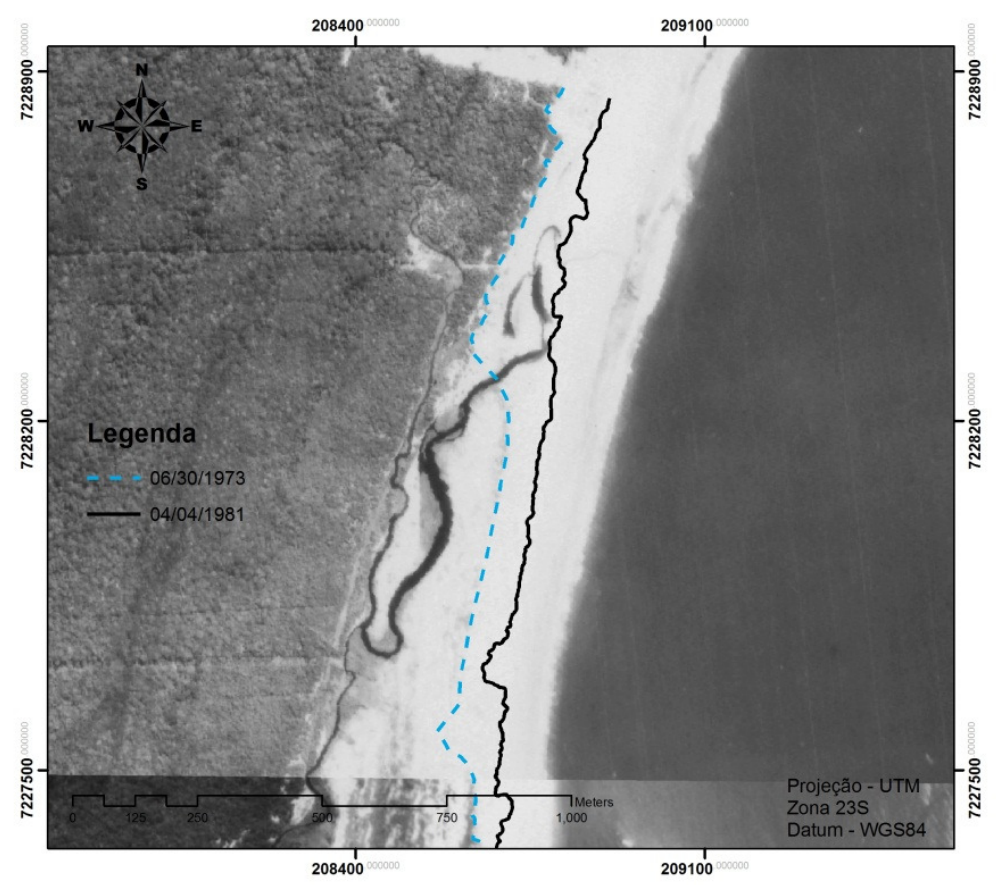

Figura 57: Linhas de costas obtidas para os anos de 1973 e 1981 sobrepostas a fotografia de 1973. Notar a presença do rio e tênue presença da linha de vegetação.

\section{3 - Análises Sedimentológicas}

Os resultados do cálculo dos parâmetros estatísticos de Folk \& Ward (1957) são apresentados nas figuras de 58 a 73. As figuras de 58 a 61 dizem respeito ao Setor 1 e as figuras de 62 a 73 ao Setor 2. A Área Leste compreende as amostras P1S2 a P8S2, e a Área Sul as amostras P9S2 a P12S2.

Foi dada prioridade a coleta de sedimentos no Setor 2, não havendo dados para os meses de junho e setembro de 2011 para o Setor 1.Em alguns meses ocorreu o extraviamento de amostras durante seu transporte para São Paulo. 


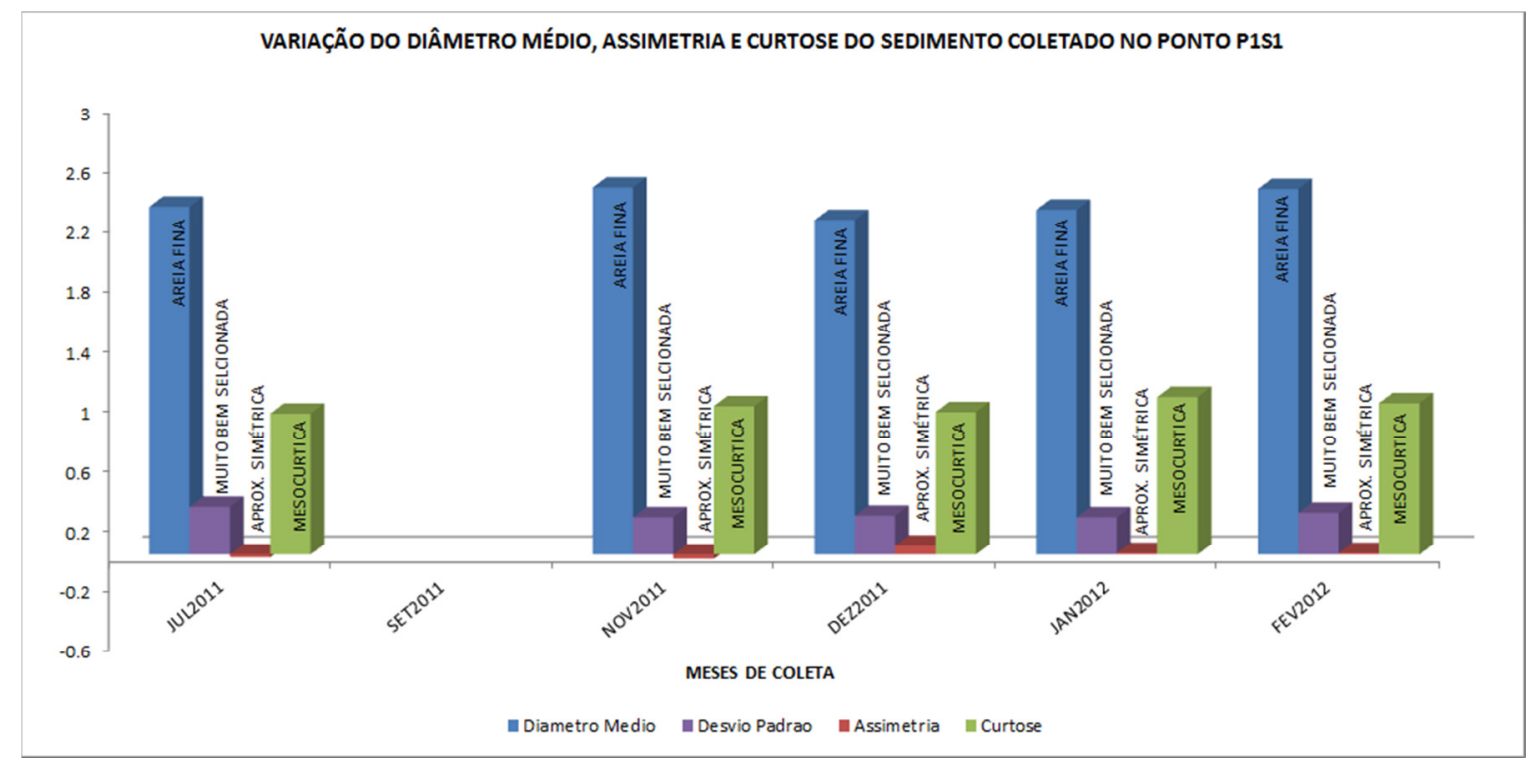

Figura 58: Resultados obtidos para variação dos parâmetros sedimentares no ponto P1S1. Barra Azul - Diâmetro Médio; Barra Roxa - Desvio Padrão; Barra Vermelha Assimetria; Barra Verde - Curtose.

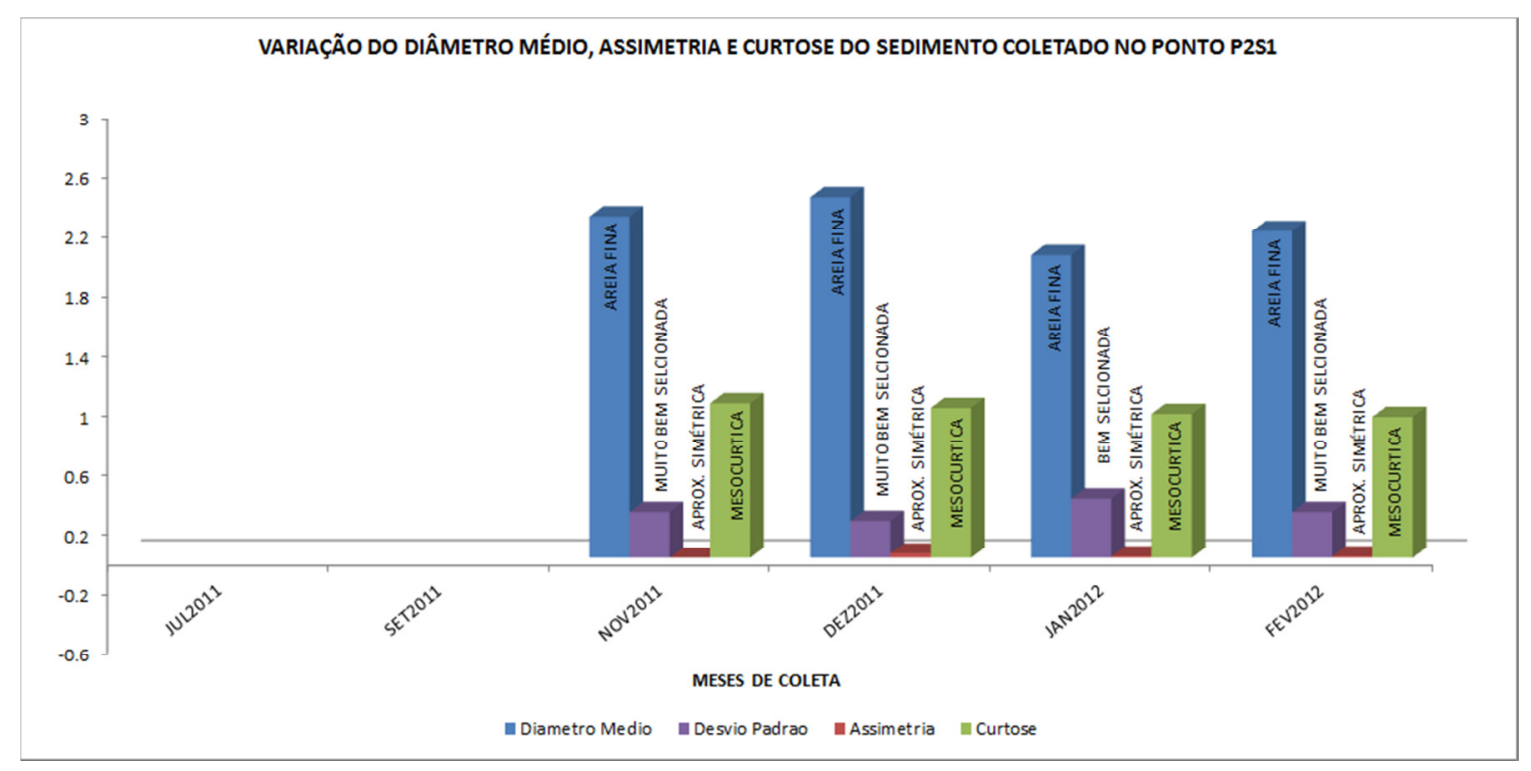

Figura 59: Resultados obtidos para variação dos parâmetros sedimentares no ponto P2S1. Barra Azul - Diâmetro Médio; Barra Roxa - Desvio Padrão; Barra Vermelha Assimetria; Barra Verde - Curtose. 


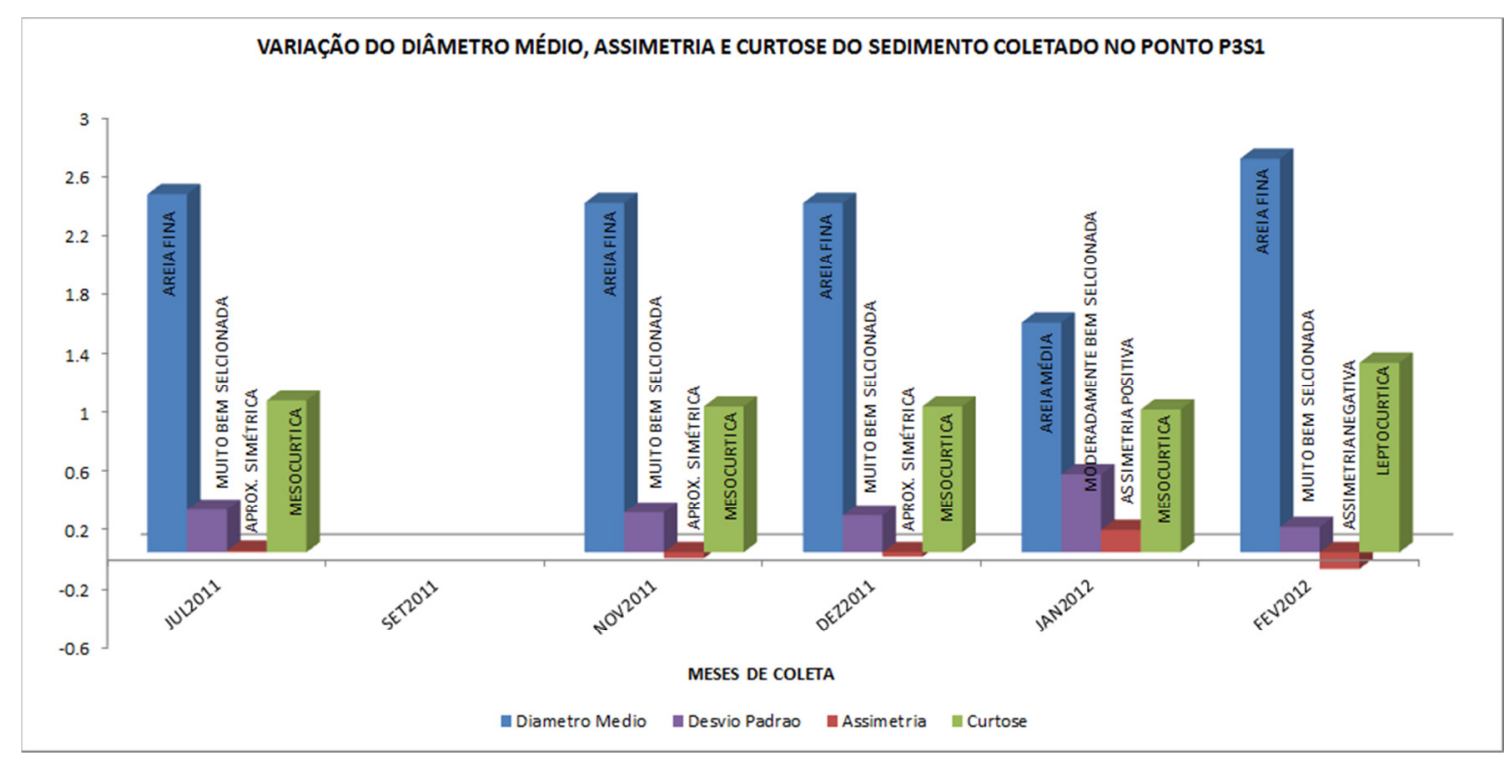

Figura 60: Resultados obtidos para variação dos parâmetros sedimentares no ponto P3S1. Barra Azul - Diâmetro Médio; Barra Roxa - Desvio Padrão; Barra Vermelha Assimetria; Barra Verde - Curtose.

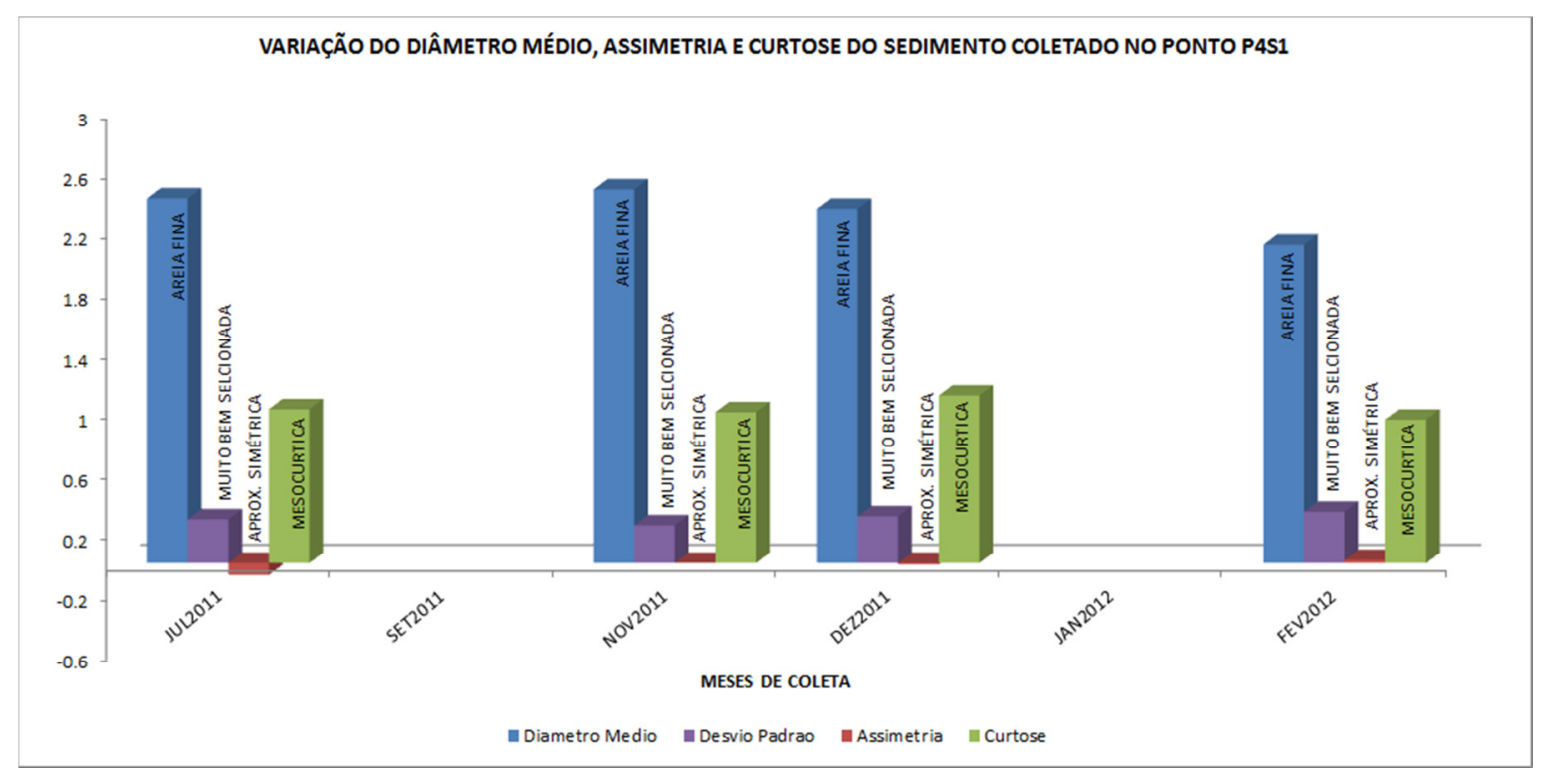

Figura 61: Resultados obtidos para variação dos parâmetros sedimentares no ponto P4S1. Barra Azul - Diâmetro Médio; Barra Roxa - Desvio Padrão; Barra Vermelha Assimetria; Barra Verde - Curtose. 


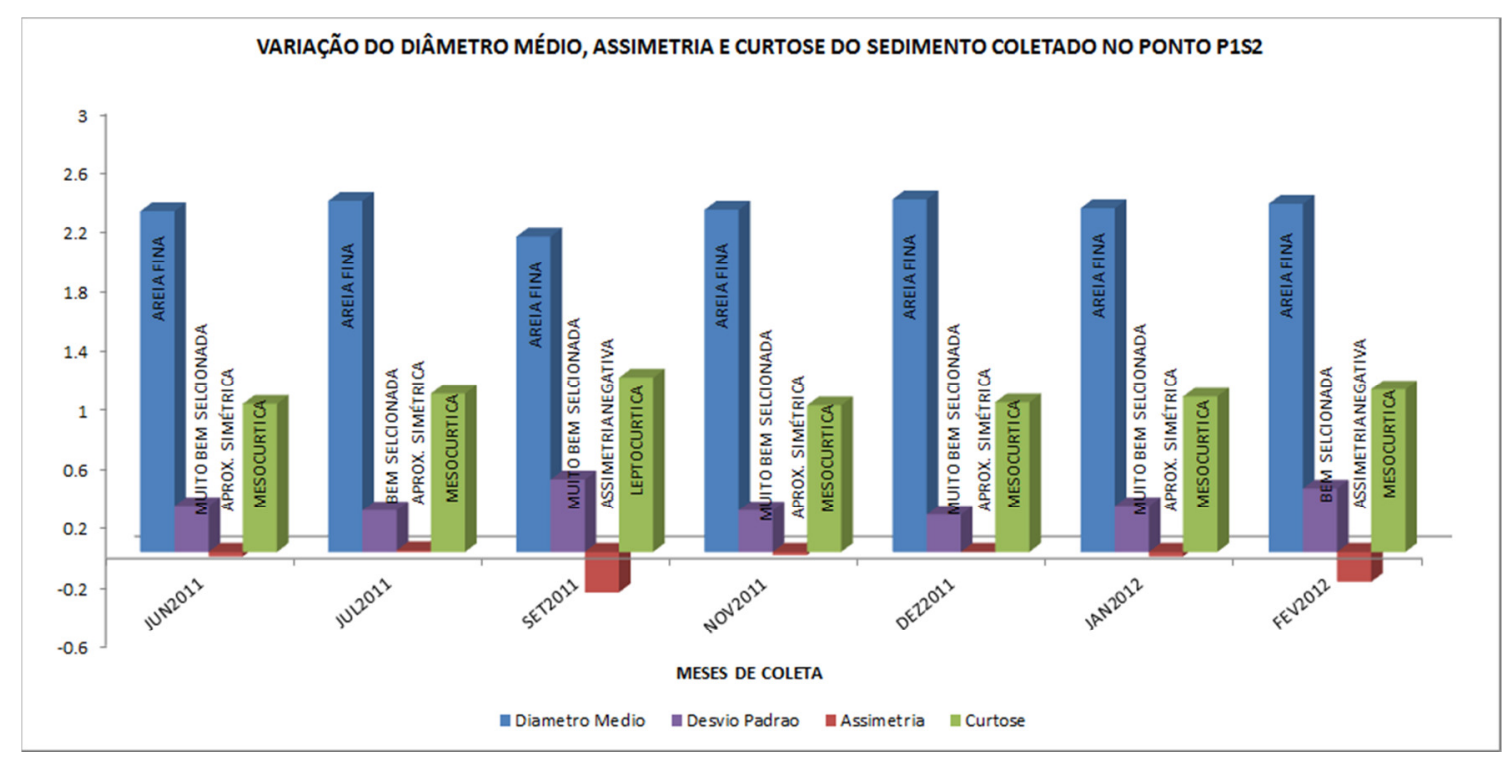

Figura 62: Resultados obtidos para variação dos parâmetros sedimentares no ponto P1S2. Barra Azul - Diâmetro Médio; Barra Roxa - Desvio Padrão; Barra Vermelha Assimetria; Barra Verde - Curtose.

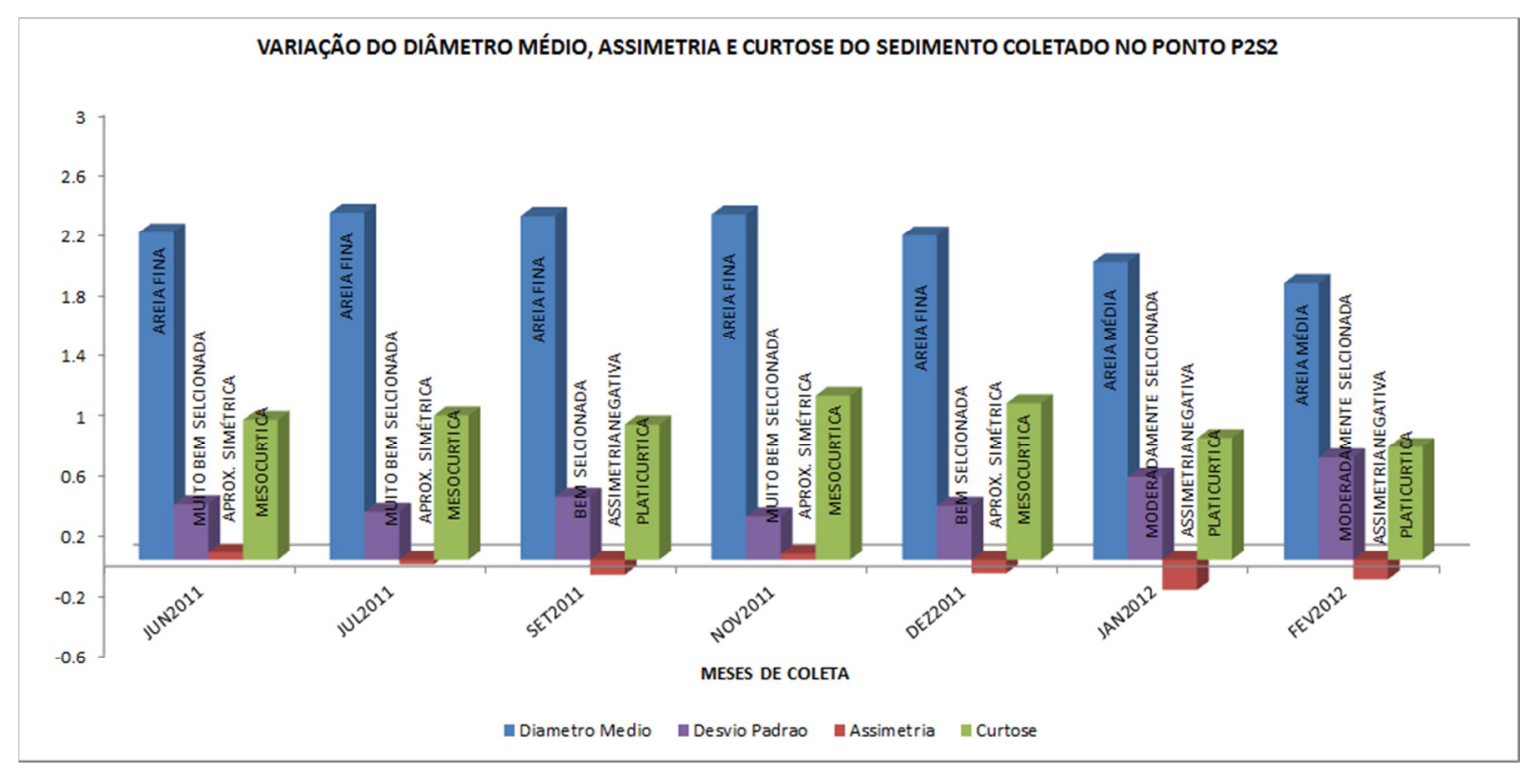

Figura 63: Resultados obtidos para variação dos parâmetros sedimentares no ponto P2S2. Barra Azul - Diâmetro Médio; Barra Roxa - Desvio Padrão; Barra Vermelha Assimetria; Barra Verde - Curtose. 


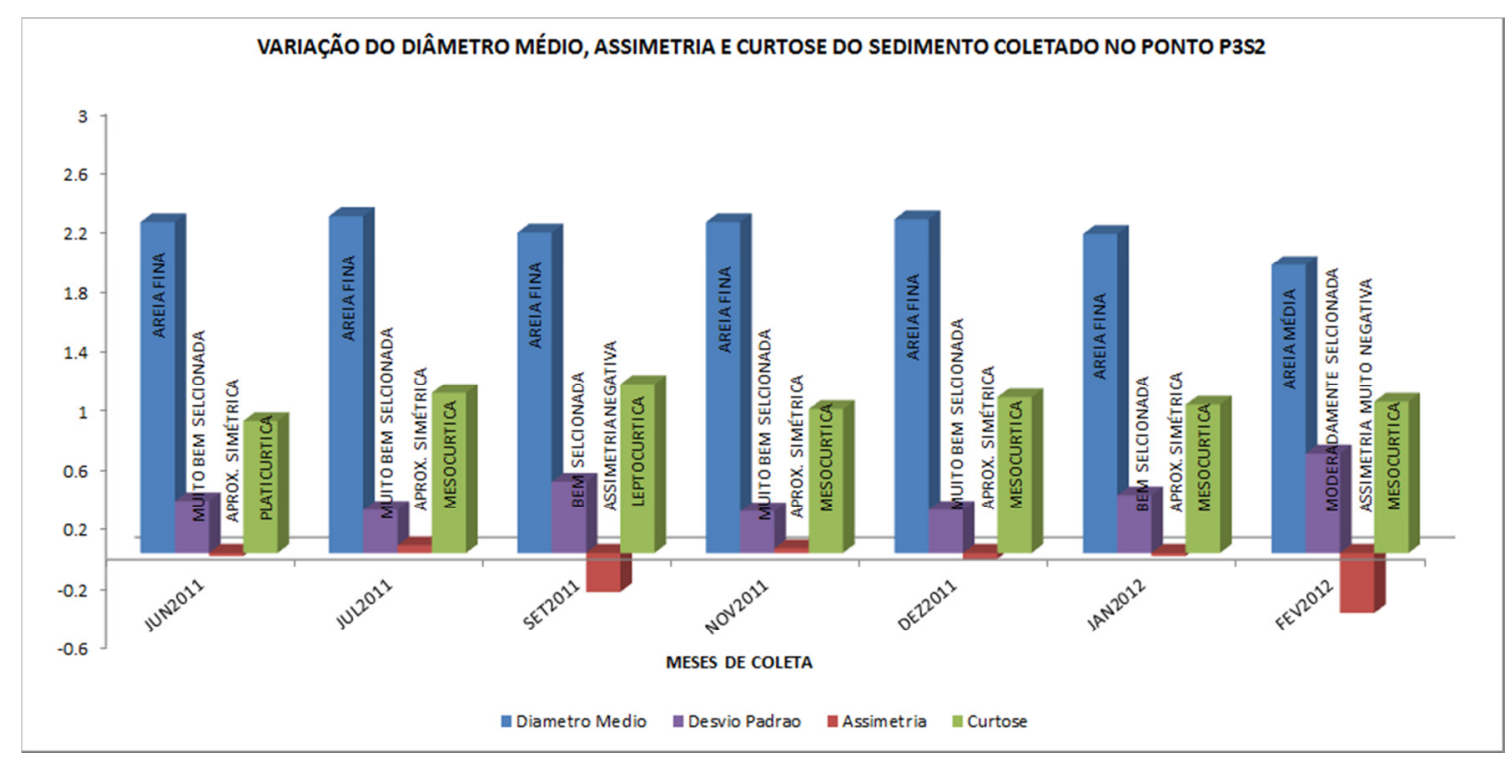

Figura 64: Resultados obtidos para variação dos parâmetros sedimentares no ponto P3S2. Barra Azul - Diâmetro Médio; Barra Roxa - Desvio Padrão; Barra Vermelha Assimetria; Barra Verde - Curtose.

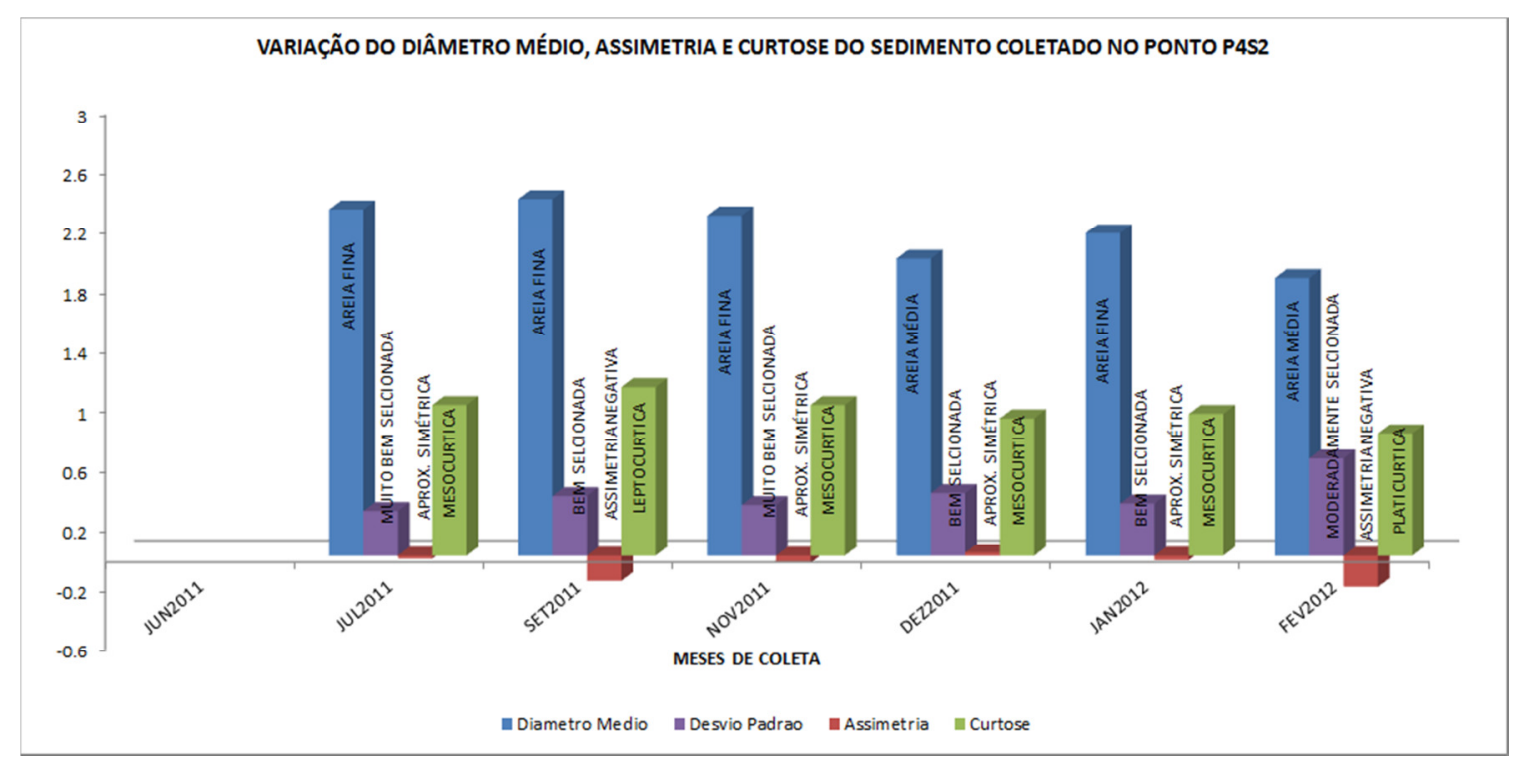

Figura 65: Resultados obtidos para variação dos parâmetros sedimentares no ponto P4S2. Barra Azul - Diâmetro Médio; Barra Roxa - Desvio Padrão; Barra Vermelha Assimetria; Barra Verde - Curtose. 


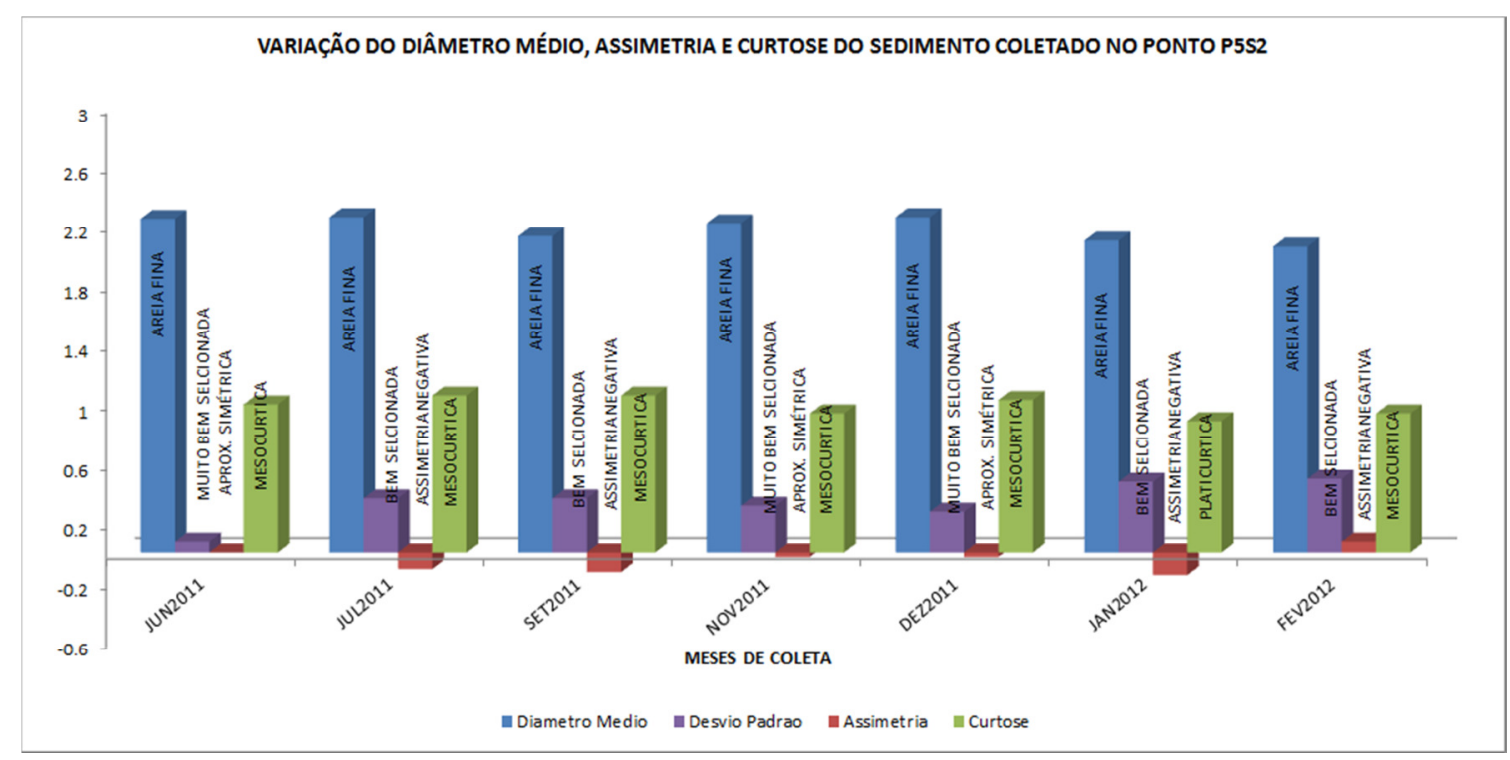

Figura 66: Resultados obtidos para variação dos parâmetros sedimentares no ponto P5S2. Barra Azul - Diâmetro Médio; Barra Roxa - Desvio Padrão; Barra Vermelha Assimetria; Barra Verde - Curtose.

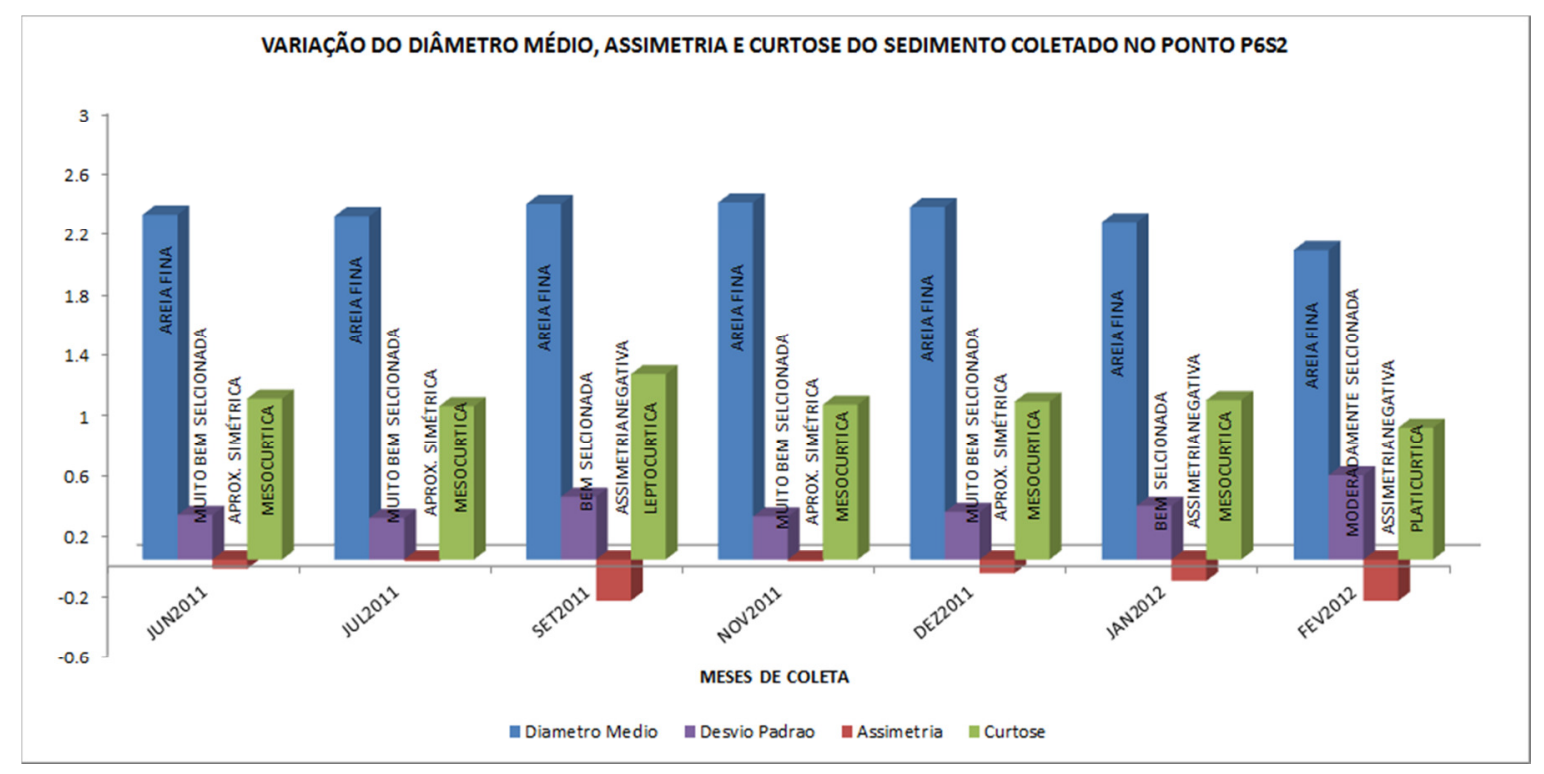

Figura 67: Resultados obtidos para variação dos parâmetros sedimentares no ponto P6S2. Barra Azul - Diâmetro Médio; Barra Roxa - Desvio Padrão; Barra Vermelha Assimetria; Barra Verde - Curtose. 


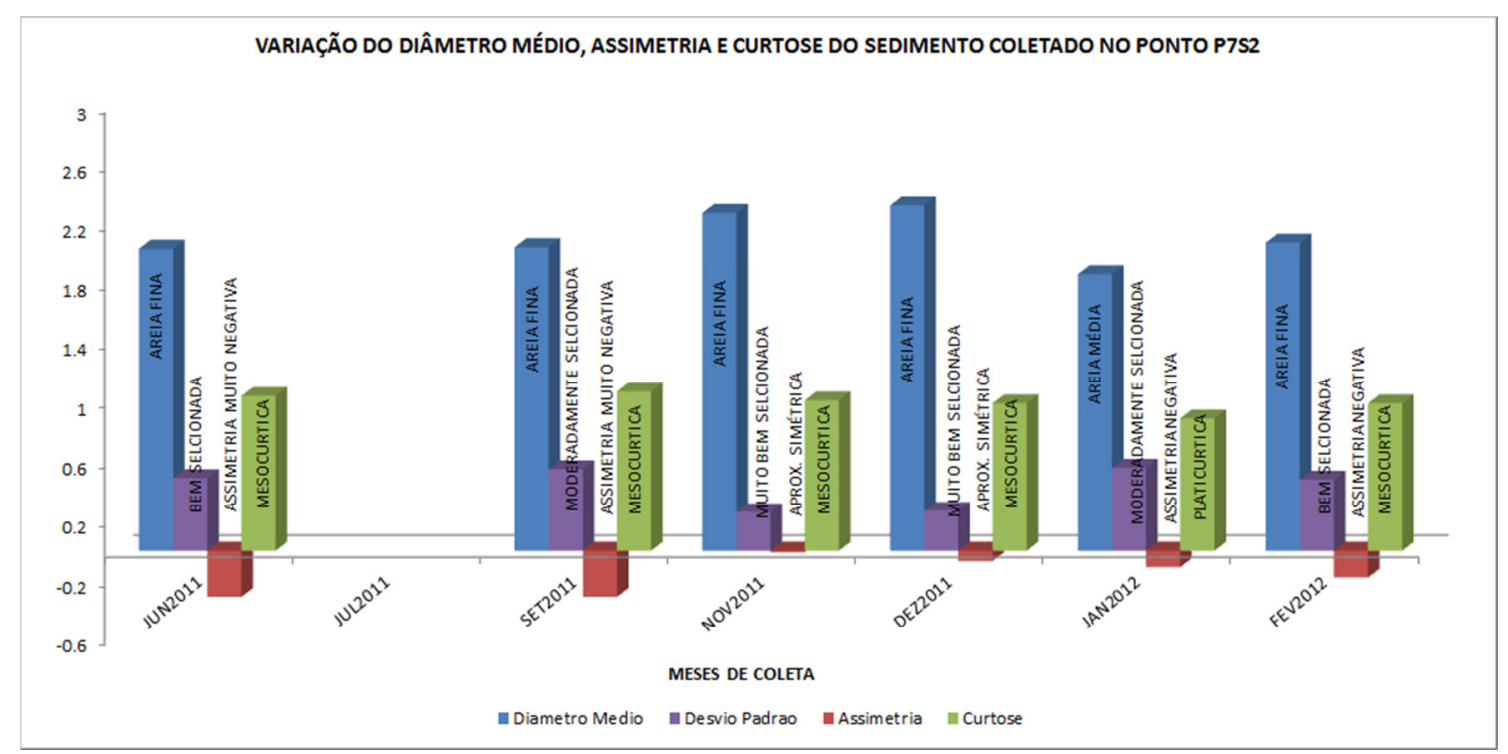

Figura 68: Resultados obtidos para variação dos parâmetros sedimentares no ponto P7S2. Barra Azul - Diâmetro Médio; Barra Roxa - Desvio Padrão; Barra Vermelha Assimetria; Barra Verde - Curtose.

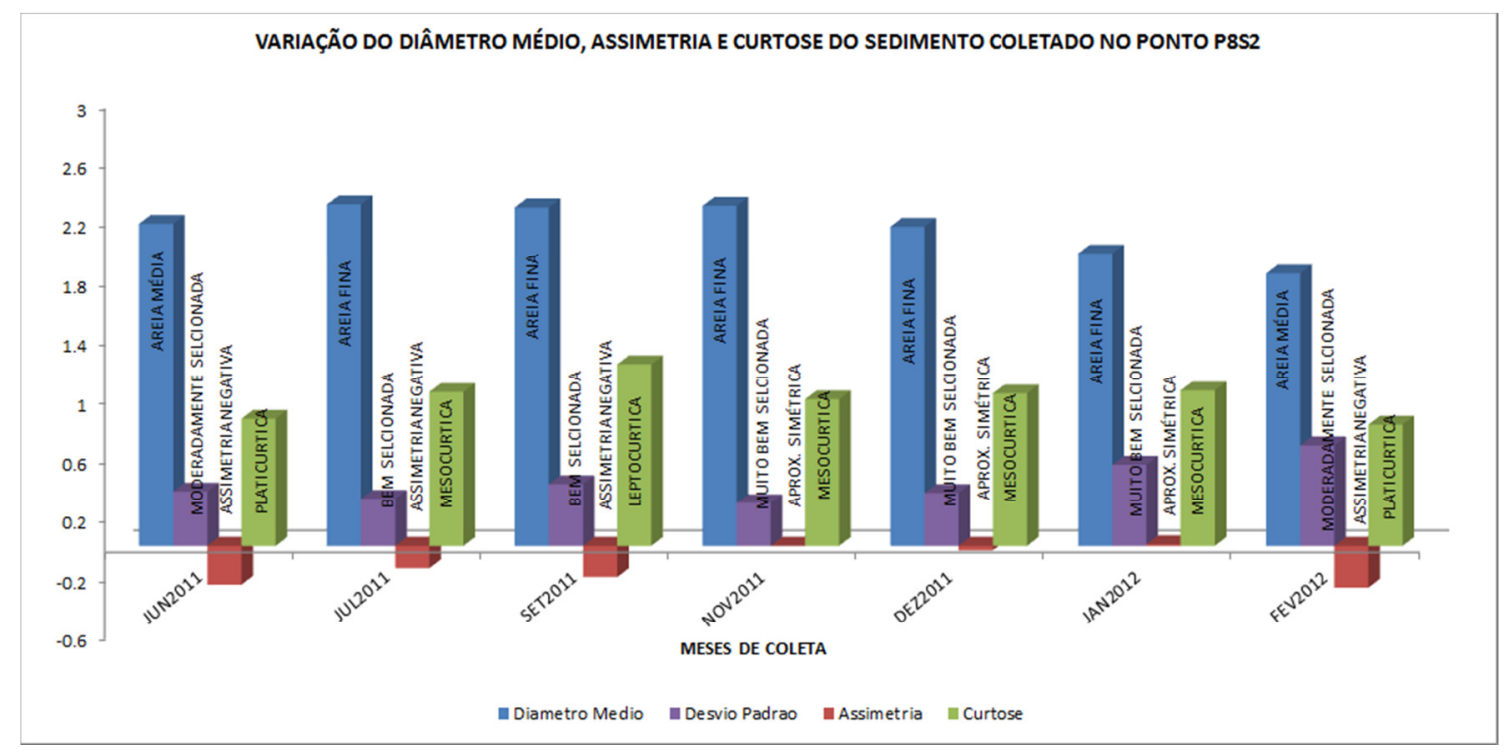

Figura 69: Resultados obtidos para variação dos parâmetros sedimentares no ponto P8S2. Barra Azul - Diâmetro Médio; Barra Roxa - Desvio Padrão; Barra Vermelha Assimetria; Barra Verde - Curtose. 


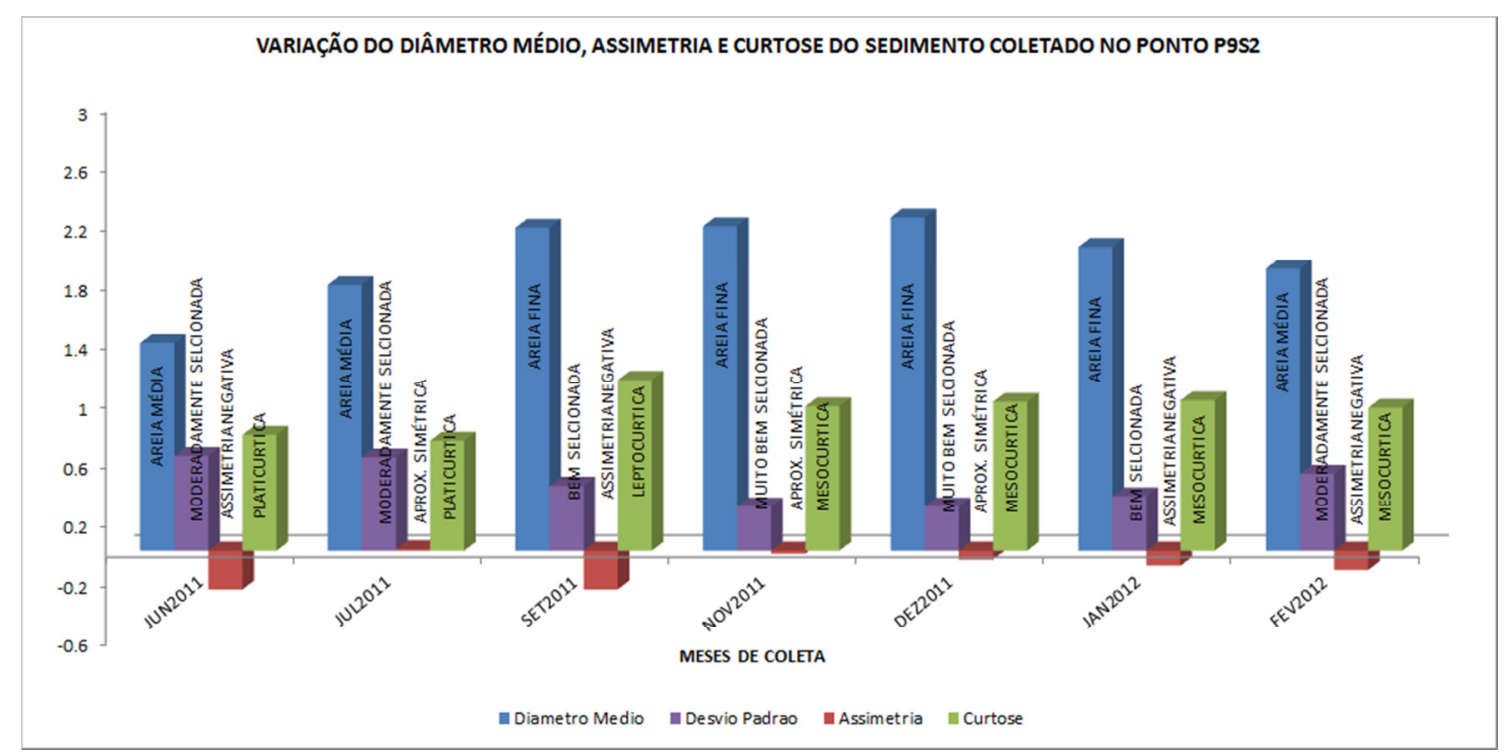

Figura 70: Resultados obtidos para variação dos parâmetros sedimentares no ponto P9S2. Barra Azul - Diâmetro Médio; Barra Roxa - Desvio Padrão; Barra Vermelha Assimetria; Barra Verde - Curtose.

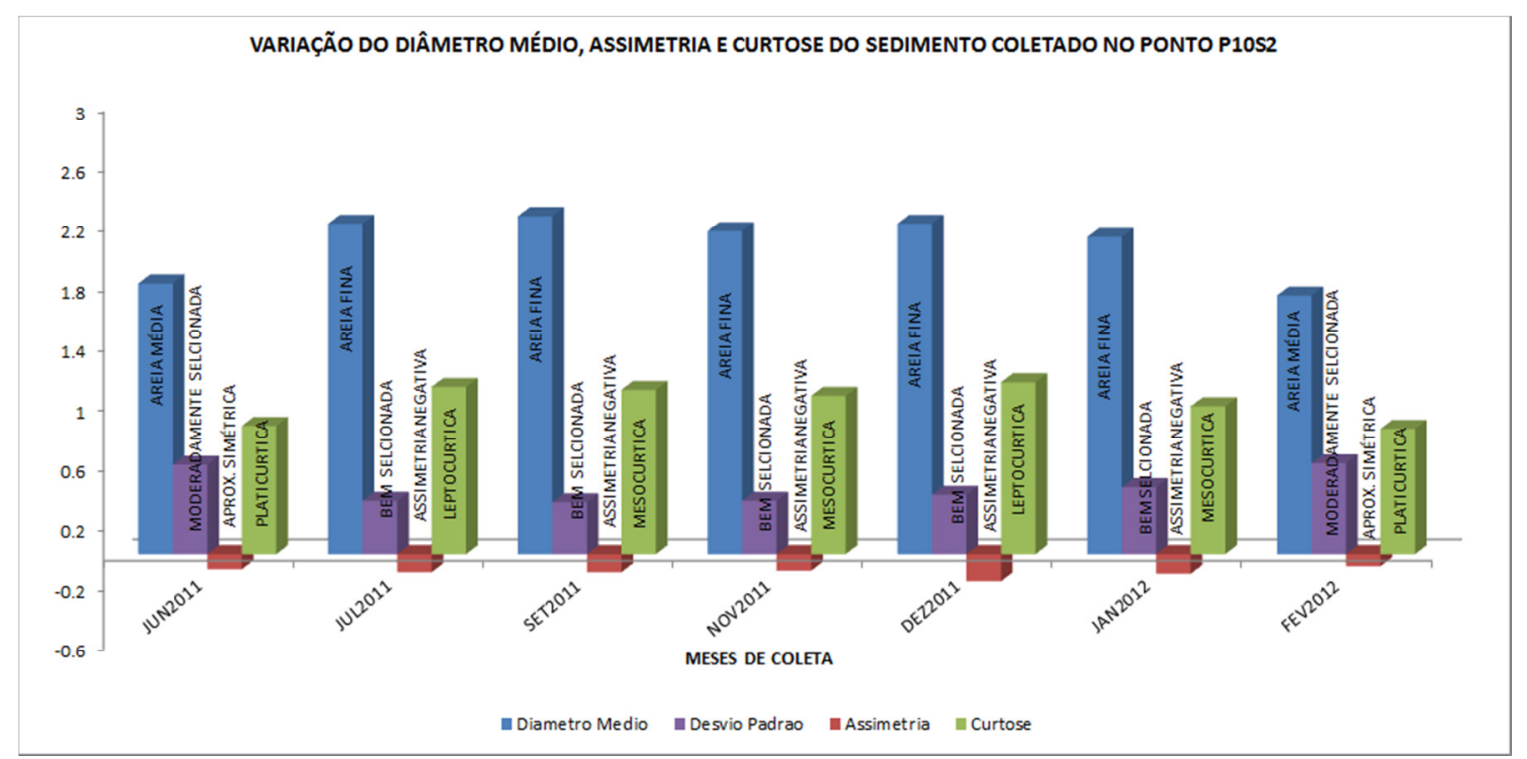

Figura 71: Resultados obtidos para variação dos parâmetros sedimentares no ponto P10S2. Barra Azul - Diâmetro Médio; Barra Roxa - Desvio Padrão; Barra Vermelha Assimetria; Barra Verde - Curtose. 


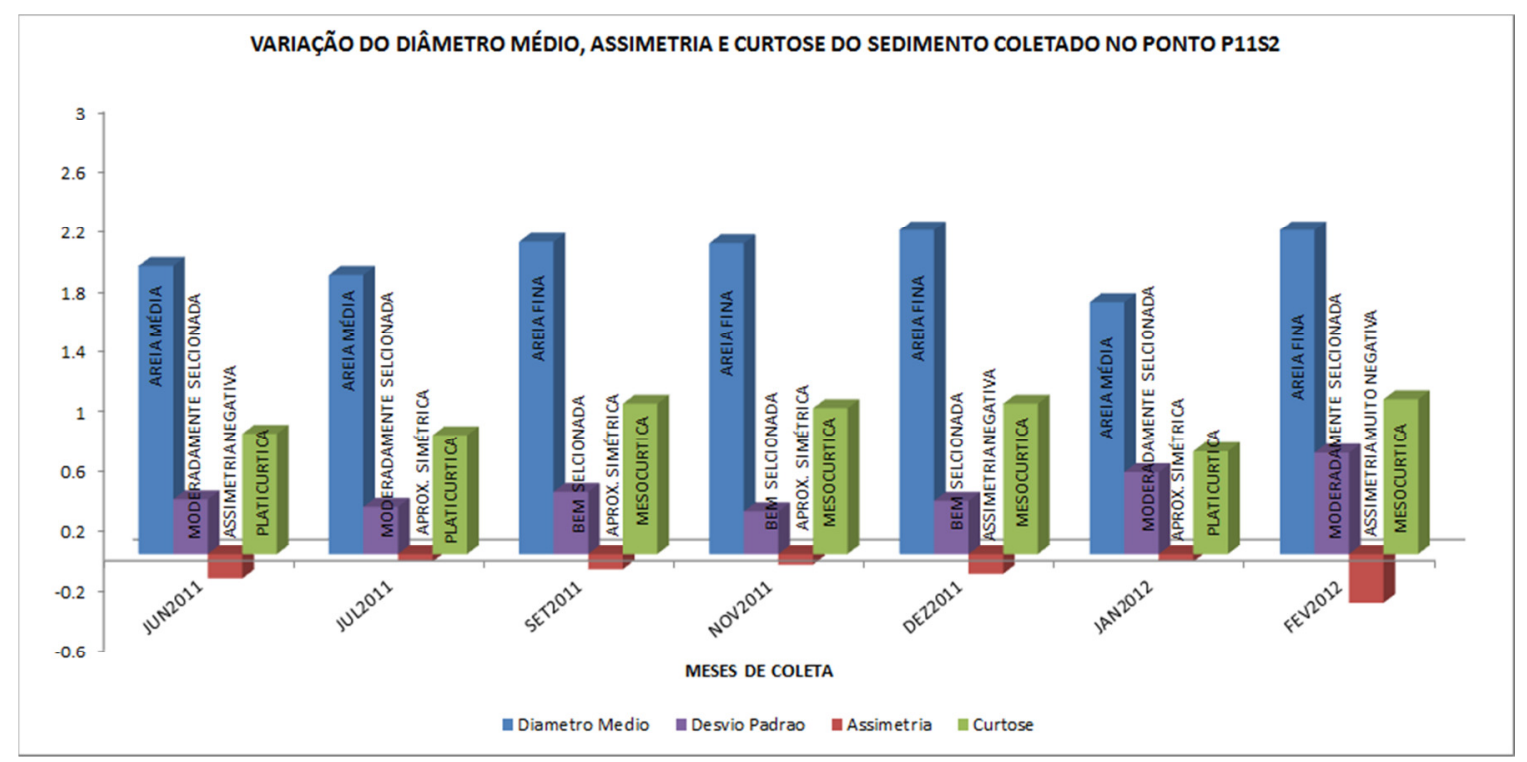

Figura 72: Resultados obtidos para variação dos parâmetros sedimentares no ponto P11S2. Barra Azul - Diâmetro Médio; Barra Roxa - Desvio Padrão; Barra Vermelha Assimetria; Barra Verde - Curtose.

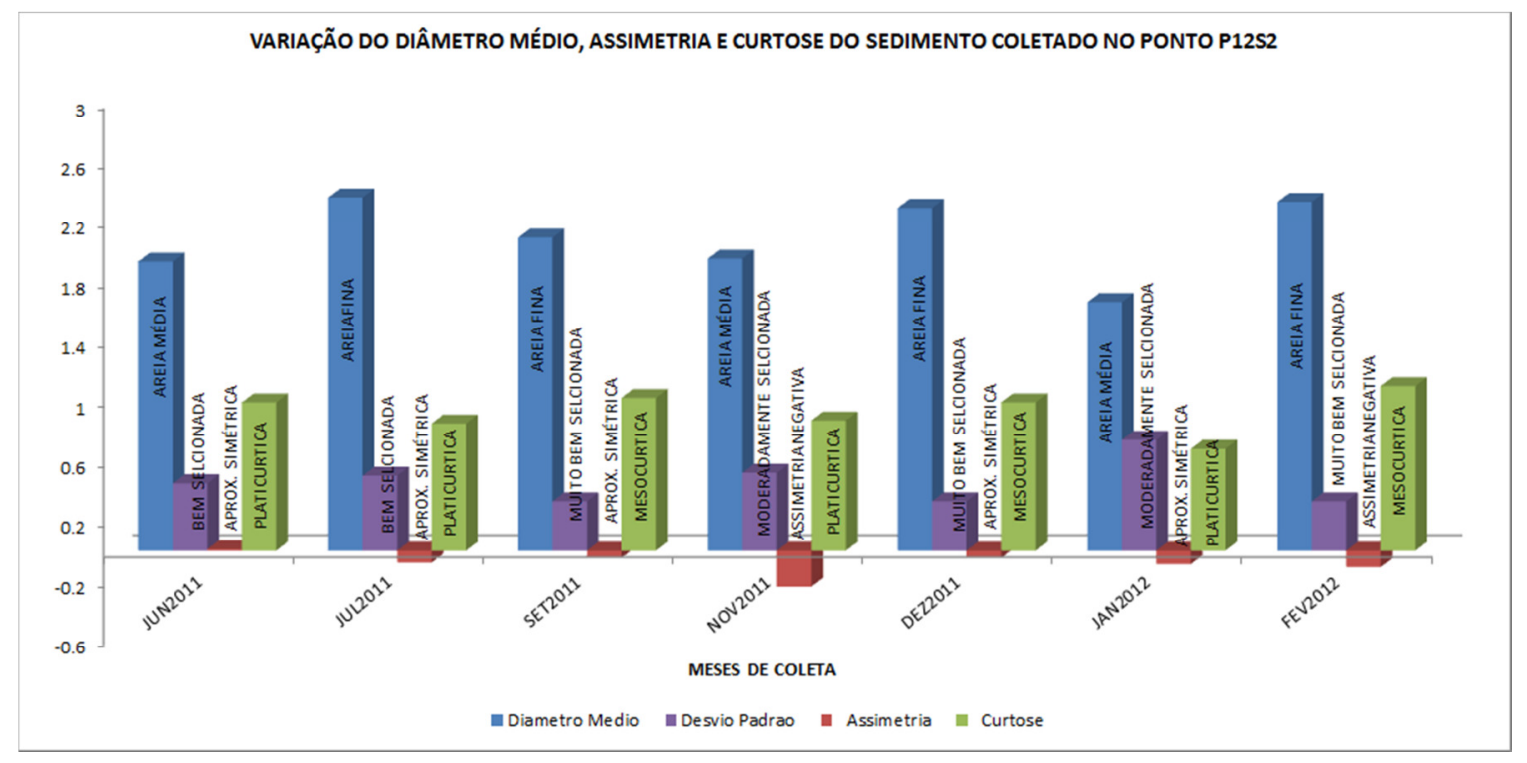

Figura 73: Resultados obtidos para variação dos parâmetros sedimentares no ponto P12S2. Barra Azul - Diâmetro Médio; Barra Roxa - Desvio Padrão; Barra Vermelha Assimetria; Barra Verde - Curtose.

O Setor 1 apresentou predominância de areia fina, ocorrendo areia média apenas no P3 no mês de Janeiro. Quanto ao desvio padrão, ocorreu o 
amplo predomínio da classificação "muito bem selecionada", com somente duas exceções, P2 e P3 no mês de janeiro de 2012. Os dados de simetria revelaram a predominância da situação "aproximadamente simétrica", as únicas exceções foram observadas no P3 nos meses de janeiro e fevereiro, apresentando tendências de assimetria positiva e assimetria negativa respectivamente. As curvas de distribuição de granulometria apresentaram características mesocúrticas em todas as análises, com a única exceção ocorrendo no P3 no mês de fevereiro que apresentou tendências leptpcúrticas.

Os sedimentos do Setor 1 demonstraram grande homogeneidade, com predominância de grãos com diâmetro médio (D50) entre 2 e 3 na escala $\Phi$, ou seja, areia fina. Os valores de simetria e desvio padrão reforçam a condição de homogeneidade, indicando pouca dispersão dos dados e grande simetria das curvas produzidas na análise. A análise da curtose das curvas amostrais revelou que na maioria das amostras a curva demonstrou comportamento normal.

Os resultados indicam que os sedimentos do Setor 1 estão sujeitos aos mesmos processos transportadores, sem muitas variações sazonais. O único ponto a destoar é P3 que aparentemente esteve sujeito a processos distintos durante os meses de janeiro e fevereiro de 2012. Uma explicação possível é o incremento das chuvas nesses meses, que pode ter gerado um escoamento mais intenso sobre a área do P3.

No Setor 2 a Área Leste apresentou uma predominância de areia fina até o mês de dezembro de 2011, nos meses de janeiro e fevereiro de 2012 foi observada a ocorrência de areias médias nos pontos P2S2, P3S2, P4S2, P7S2 e P8S2. Os resultados de desvio padrão revelam um domínio de amostras 
muito bem selecionadas e bem selecionadas, contudo no mês de fevereiro de 2012 houve a ocorrência de classificações moderadamente selecionadas para as amostras P2S2, P3S2, P4S2, P6S2 e P8S2. As curvas produzidas demonstraram comportamento aproximadamente simétrico ou assimetria negativa em quase todos os casos, a únicas exceções são os pontos P3S2 w P7S2, que apresentaram assimetria muito negativa nos meses de fevereiro e setembro respectivamente. O parâmetro da curtose apresentou comportamento variado, com leve predomínio das curvas mesocúrticas.

A Área Sul apresentou uma alternância dos valores de diâmetro médio, com a predominância de areia média nos meses de junho/2011 e fevereiro/2012, e domínio de areia fina no restante do período. Os valores de desvio padrão acompanham esta tendência, apresentando valores de classificação moderadamente selecionada nos meses de junho/2011 e fevereiro/2012 enquanto no restante do período as amostras foram classificadas com bem ou muito bem selecionadas. Os valores de assimetria variaram entre aproximadamente simétricos e negativos, sem um padrão de variação temporal claro. Os pontos P9S2 e P10S2 apresentaram as três classificações possíveis para a curtose, com a ocorrência de valores leptocúrticos nos meses de junho e julho de 2011, já os pontos P11S2 e P12S2 alternaram entre valores mesocúrticos e platicúrticos.

Os resultados da Área Leste foram marcados pela predominância inicial de areia fina, a ocorrência de areia média nos meses de janeiro e fevereiro de 2012 parece estar associada a intensificação das chuvas. Os pontos P2S2 e P3S2 se encontram na área mias ao norte, sob a influência do rio que desagua na face praial, a incidência de areias médias nos meses de 
verão denota o aumento do fluxo deste corpo d'água. Tal situação é comprovada pelos valores de desvio padrão que indicam sedimentos moderadamente selecionados, evidenciando a ação de fluxos bidirecionais (Tessler, 1982). O mesmo processo pode ser notado quanto aos pontos P7S2 e P8S2 que se encontram mais próximos a Desembocadura de Cananéia, e por tanto a ocorrência de areias médias e sedimentos moderadamente selecionados reflete a intensificação do fluxo das correntes de maré.

Na Área Sul os resultados de diâmetro médio indicam a atuação de fluxos mais intensos nos meses de junho e julho e 2011 e fevereiro e janeiro de 2012. De forma análoga os resultados a cerca do desvio padrão indicam a atuação de fluxos bidirecionais nos mesmos períodos. As razões para este comportamento parecem residir na atuação das frentes frias durantes os meses de inverno, intensificando a ação das ondas em um setor normalmente protegido, e ao fortalecimento das correntes de maré vazante na Desembocadura de Cananéia durante os meses chuvosos do verão.

Os resultados de assimetria das curvas para todos os setores estão de acordo com o esperado. Os resultados exibiram uma tendência de assimetria negativa, característicos de depósitos sedimentares residuais expostos a ação das ondas (Cunha \& Guerra, 2002).

A curtose indica a esbelteza da uma curva, o seu significado geológico não é muito claro. Fúlfaro e Ponçano (1975), em seu estudo sobre a distribuição de sedimentos sobre o estuário santista, associam os valores leptocúrticos a regiões com transporte de sedimentos e valores platicúrticos a áreas de deposição. No presente estudo valores leptocúrticos só foram encontrados nos pontos P9S2 e P10S2, localizados nas imediações da curva 
fisiográfica da Desembocadura de Cananéia, enquanto todo Setor 2 apresentou valores platicúrticos, porém a predominância geral foi de comportamento mesocúrtico.

\section{4 - Dados Topográficos}

Foram produzidos MDTs para todos os levantamentos executados (Figura 74), e a partir da subtração destes, novos MDTs com as diferenças de altimetria. Foram elaborados mapas de diferenças altimétricas e comparação de perfis praias dia a dia desde 03/06/2011 até 24/02/2012, sendo as diferenças na escala diária praticamente insignificantes. Apenas um evento significativo foi registrado, com os demais mapas dizendo respeito a comparações mensais. Os mapas são compostos pela subtração de dois MDTs e sobreposição de seus perfis praiais.

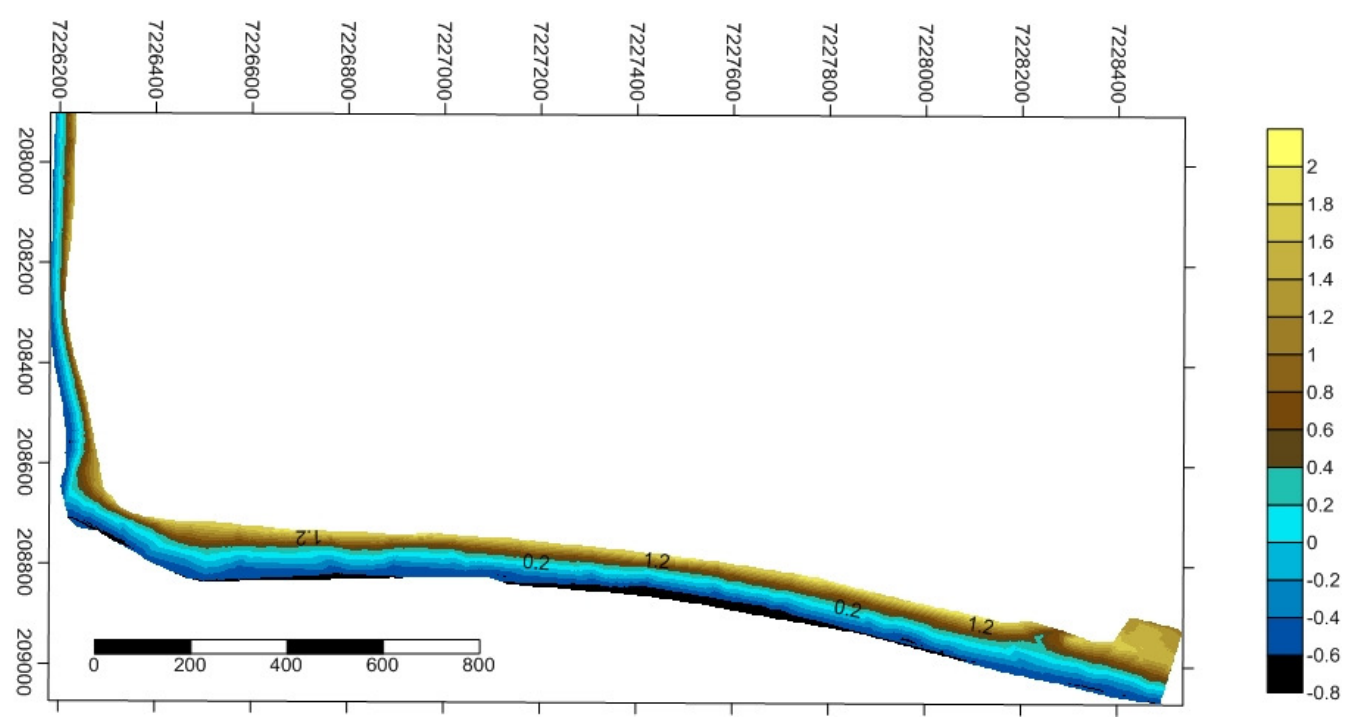

Figura 74: MDT gerado a partir dos dados do levantamento do dia 23/11/2011. 
Os mapas de comparação se encontram dispostos no Anexo I.

\subsection{1 - Coletas Mensais}

\subsubsection{1 - Área Leste}

A figura A1 expõe os resultados da comparação entre os dias 06/06/2011 e 19/07/2011. Os dados indicam que a maior parte do pós-praia se manteve praticamente estável, apresentando entre -0,2 e 0,2 m de diferença altimétricas, principalmente na porção central da área. As maiores variações são encontradas nos extremos norte e sul.

A porção norte apresenta uma área de erosão pontual nas proximidades do perfil 3 , com valores máximos de $-1 \mathrm{~m}$. A feição provavelmente está ligada a modificação antrópica do curso de um rio presente nesta área. A área mais ao sul apresenta uma área mais extensa de erosão localizada nas adjacências do perfil 11, variando entre -0,2 e - $-0,8 \mathrm{~m}$, em volta da área em questão ocorreram as maiores variações positivas deste período, atingindo valores de 0,8 m de elevação, como indicado pelos perfis 10 e 12 .

A figura A2 apresenta as comparações entre os dias 26/07/2011 e 12/08/2011. Desta vez praticamente todo o prisma praial apresentou variações altimétricas negativas indicando processos erosivos. Novamente as porções que apresentaram as maiores variações foram às extremidades.

$\mathrm{Na}$ porção mais ao norte as variações mais extremas ocorreram de maneira pontual e próximas entre si. O perfil 11 exibiu os valores mais positivos $(0,9 \mathrm{~m})$ e perfil 12 os valores mais negativos $(-0,7 \mathrm{~m})$. A porção mais ao sul apresentou novamente as maiores alterações negativas nas proximidades do perfil 3, de maneira mais restrita, atingindo até -0,9 m. 
Os resultados referentes à comparação entre os dias 12/08/2011 e 26/09/2011 estão representados na figura A3. De modo geral a porção do prisma praial mais próxima do limite da vegetação apresentou valores negativos de diferença altimétricas, variando entre $-0,5$ e $-0,1 \mathrm{~m}$, enquanto a porção mais próxima ao mar apresentou variações positivas com valores entre 0,1 e $0,5 \mathrm{~m}$.

A porção mais ao norte continua a apresentar valores negativos máximos da comparação concentrados em um pequeno trecho. No entanto, nesta comparação o foco de erosão de encontra mais próximo do perfil 2 , atingindo $-1,3$ m. A porção mais sul manteve as variações mais positivas concentradas nas proximidades do perfil 11 , com valores entre 0,5 e $0,7 \mathrm{~m}$.

A figura A4 apresenta os resultados obtidos na comparação entre 29/09/2011 e 21/11/2011. Observa-se que a maior parte da área estudada apresentou pequena variação, exibindo valores entre $-0,1$ e 0,3 , com alguns pontos esparsos apresentando valores de variação entre 0,5 e -0,5 m.

A porção mais ao norte continua a apresentar o mesmo padrão das outras comparações, exibindo os valores mais negativos de variação altimétrica em um pequeno trecho na zona entre os perfis 2 e 3 , atingindo $-0,7 \mathrm{~m}$. A porção mais ao sul não voltou a apresentar elevações dispares de altura, mas nas redondezas do perfil 12 verificou-se um rebaixamento com valores entre $-0,3$ e $-0,7 \mathrm{~m}$.

A figura A5 representa os resultados referentes a comparação entre os meses de novembro e dezembro (24/11/2011 e 13/12/2011). Os dados revelam a menor amplitude de variação da altitude, ficando entre -0,6 e 0,6 m. De modo geral toda praia apresentou um padrão de estabilidade, exibindo 
valores de variação entre - 0,2 e 0,2 m, com algumas áreas esparsas apresentando valores negativos na ordem de $-0,4 \mathrm{~m}$.

A porção mais ao norte voltou a exibir valores negativos, com menor intensidade, na ordem de $-0,4 \mathrm{~m}$. Nas proximidades do perfil 12 ocorreu a inversão da tendência observada nos últimos resultados, apresentando os maiores valores positivos da comparação em questão $(0,6 \mathrm{~m})$.

A figura A6 apresenta os resultados da comparação entre os dias 13/12/2011 e 27/01/2012. Novamente a porção amostrada exibe tendências de estabilidade, estando sua maior parte englobada na variação de -0,2 e 0,2 m. Os maiores valores de erosão ocorrem na parte mais ao sul concentrados na zona entre os perfis 2 e 3, com valores entre - $-0,6$ e -1 m. Na porção mais ao sul nota-se uma área de variação negativa nas redondezas do perfil 11, com valores entre $-0,4$ e $-0,8$.

A figura A7 é referente à comparação entre os dias 29/01/2012 e 24/02/2011. De modo geral a praia demonstrou uma leve elevação das alturas na porção mais central, apresentando valores entre 0,5 e 0,25 m.

A porção mais ao norte voltou a demonstrar rebaixamentos na zona entre os perfis 2 e 3 , com valores na casa de $-0,55 \mathrm{~m}$. A porção mais ao sul apresentou rebaixamentos pontuais na ordem de $-0,75 \mathrm{~m}$, com destaque para a elevação na área do perfil 11 e o rebaixamento nas proximidades do perfil 10 , apresentando respectivamente valores de até 0,45 e -0,55 m.

A figura A8 exibe o mapa comparando o primeiro e o último dia de levantamento topográfico, 03/06/2011 e 26/02/2012, objetivando apresentar uma tendência geral da dinâmica ocorrida durante o período de saídas a campo. Os resultados revelam uma tendência de elevação altimétrica para a 
maioria da área de estudo, variando entre 0,1 e $0,5 \mathrm{~m}$. Somente nas extremidades são encontrados valores discrepantes.

A porção localizada entre os perfis 2 e 3 se caracterizou como o trecho com os maiores valores de variação negativa, especialmente nas proximidades do início da vegetação, com valores entre $-0,7$ e $-1,5 \mathrm{~m}$. Também pode ser notado um trecho com variações negativas mais brandas $(-0,5$ a $-0,7)$ na área adjacente a interface com o mar no perfil 3, provavelmente ligadas a alteração do leito do rio presente nesta área.

A porção mais ao sul, localizada entre os perfis 11 e 12 apresentou variações altimétricas negativas entre $-0,5$ e - 0,9 , já na seção entre os perfis 10 e 11 se observa uma área com variações positivas entre 0,5 e 0,7 m.

\subsubsection{2 - Área Sul}

A figura A9 exibe os resultados para a comparação entre os dias 06/06/2011 e 19/07/2011, onde podem ser observados três padrões distintos. A porção a localizada no extremo leste da figura apresentou as maiores variações positivas 0,05 e $0,45 \mathrm{~m}$. Na área entre os perfis 13 e 15 se encontra uma área com predominância de valores negativos, variando entre - $-0,35$ e -0,9 m. A porção mais oeste, a partir do perfil 15, apresenta características mais estáveis no limite da vegetação, com valores variando entre 0,05 e -0,15 m. Em sua porção mais próxima a água os valores se tornam mais negativos, estando inseridos no intervalo entre $-0,35$ e $-0,55 \mathrm{~m}$.

Os resultados referentes à comparação entre julho e agosto, 27/07/2011 e 12/08/2011, estão expressos na figura A10. Os dados revelam uma variação branda das altimetrias, variando entre 0,25 e -0,55 m. A porção 
leste, nas proximidades do perfil 13, apresentou valores positivos de altimetria, variando entre 0,05 e $025 \mathrm{~m}$. A porção entre o perfil 14 e proximidades do perfil 15, apresentou variação negativa, com valores variando entre -0,35 e -0,55 m. A porção mais oeste, englobando os perfis 16 e 17, praticamente se manteve estável apresentando valores de diferença altimétrica entre 0,05 e -0,15 m.

A comparação entre os dias 12/08/2011 e 27/09/2011 está demonstrada na figura A11. A maior parte de área contemplada na análise sofreu diminuição em sua altura, com destaque para área próxima do limite leste, que apresentou uma grande faixa com valores de variação de $-0,8 \mathrm{~m}$. A porção entre o perfil 13 e 15 apresentou variações menos intensas, entre -0,4 e $0 \mathrm{~m}$. Já porção mais oeste apresentou um padrão de rebaixamento no limite da vegetação e elevação nas proximidades do mar, variando entre 0,4 e -0,4 m.

A figura A12 apresenta os resultados da comparação entre 29/09/2011 e 21/11/2011. Novamente a porção leste apresentou acentuada erosão, com resultados entre $-0,3$ e $-1,1 \mathrm{~m}$, estando o foco de tal processo deslocado na direção oeste em face da comparação anterior (proximidades do perfil 13). A porção entre o perfil 14 e o perfil 16 apresenta variação de altura positivas entre 0,1 e $0,5 \mathrm{~m}$, sendo os últimos localizados nas proximidades do perfil 15. A porção mais oeste (entre os perfis 15 e 17) apresentou o mesmo padrão em relação à comparação anterior, apresentando erosão nas proximidades da vegetação e acreseção em direção ao mar, com valores entre -0,3 e 0,3 m.

A figura A13 ilustra a comparação entre os dias 24/11/2011 e 13/12/2011. Como nas duas últimas comparações, a zona mais ao leste apresenta valores de variação altimétrica negativos, principalmente no perfil 13, com valores máximos de $-0,65 \mathrm{~m}$. Nas proximidades do perfil 14 ocorre uma 
área com valores positivos entre 0,15 e 0,55 m. A partir desta feição até o limite oeste, ocorrem valores negativos de diferenças de altura, menos intensas que na porção leste, variando entre -0,05 e -0,45 m.

Os resultados referentes as diferenças altimétricas entre os dias 13/12/2011 e 27/01/2012 estão apresentados na figura A14. Nesta comparação a porção leste apresentou valores positivos, contrariando a tendência dos dois últimos períodos, variando entre 0,2 e 0,6 m. A partir perfil 13 até o limite oeste o prisma praial ocorrem valores entre 0 e $-0,6 \mathrm{~m}$, com os valores negativos concentrados na porção mais próxima a vegetação.

A figura A15 apresenta os resultados referentes aos dias 29/01/2012 e 24/02/2012. A porção leste continua a exibir valores positivos de variação altimétrica, mantendo praticamente a mesma amplitude, 0,15 a 0,55 m. Na porção entre o perfil 13 e o limite oeste da área estudada ocorreu uma inversão da tendência exibida na última análise, ou seja, os valores negativos desta vez se encontram mais próximos ao mar e as variações positivas nas proximidades da vegetação, com valores entre 0,35 e -0,45 m.

A figura A16 ilustra a comparação entre junho de 2011 e fevereiro de 2012, 03/06/2011 e 26/02/2012. Na porção leste são observadas variações altimétricas positivas que chegam até $0,8 \mathrm{~m}$, sendo mais notáveis nas proximidades do perfil 13. A zona entre os perfis 14 e 16 apresenta resultados negativos, principalmente nas adjacências do perfil 15, variando entre $-0,6$ e $-1,8$ m. A região entre o perfil 16 e o limite oeste demonstra uma tendência erosiva menos intensa, apresentando valores entre $-0,4$ e $-0,8 \mathrm{~m}$, com os valores mais negativos próximos a ação do mar. 


\subsubsection{3 - Setor 1}

A figura A17 diz respeito à comparação entre os dias 07/06/2011 e 19/07/2011. Os dados indicam uma pequena variação entre as alturas, ficando a maior parte praia entre 0,1 e $-0,1 \mathrm{~m}$, com algumas áreas esparsas apresentando variações de 0,3 e -0,3 m. A única exceção é a porção mais ao norte, entre o perfil 1 e proximidades do perfil 2, que apresenta variação positiva nas zonas próximas ao mar com variações altimétricas de até $0,3 \mathrm{~m}$.

A figura A18 ilustra os resultados da comparação entre os dias 27/07/2011 e 28/09//2011. De modo geral, toda extensão da área estudada apresentou tendência erosiva, sendo mais intensa na zona mais próxima ao mar, chegando a valores máximos de -0,6 m, com exceção da porção próxima ao perfil 2 que não apresentou variação. A região entre o perfil 2 e o perfil 3 demonstra uma leve elevação na área próxima a vegetação, com valores positivos de 0,2 $\mathrm{m}$.

Os resultados expressos na figura A19 são referentes a comparação entre setembro e novembro de 2011 (29/09/2011 e 21/11/2011). A porção entre

os perfis 1 e 2 apresentou uma tendência erosiva na zona próxima a vegetação, com valores máximos de $-0,45 \mathrm{~m}$, e variações positivas na zona próxima a ação do mar, chegando até $0,55 \mathrm{~m}$. A região entre o perfil 2 e o limite sul apresentou valores entre 0,15 e $-0,05 \mathrm{~m}$, com exceção de uma faixa próxima ao perfil 3 que apresentou valores entre - $-0,25$ e -0,45 m, e da área do perfil 4 com rebaixamento na ordem de $0,25 \mathrm{~m}$.

A comparação entre os dias 24/11/2011 e 13/12/2011 está representada na figura $\mathrm{A} 20$. De maneira geral, os resultados demonstram diminuição das altitudes em quase toda a extensão da praia. Valores positivos 
estão presentes somente nas proximidades do perfil 2, variando entre $0,05 \mathrm{e}$ 0,25 m, e em uma pequena área no limite sul, próxima ao início da zona vegetada, com valores entre 0,25 e 0,45 m. Os valores mais negativos estão presentes na zona próxima ao início da vegetação, variando entre -0,15 e $-0,35 \mathrm{~m}$.

A figura A21 ilustra as diferenças altimétricas entre os dias 13/12/2012 e 28/01/2012. Oos resultados indicam uma situação de estabilidade com a maioria da área estudada variando entre -0,1 e 0,1 m. São observadas zonas com acesção de sedimentos na região próxima da linha de vegetação, apresentando valores maiores $0,3 \mathrm{~m}$ nas proximidades do perfil 3 , e entre $0,1 \mathrm{e}$ 0,3 m nas adjacências do perfil 1 .

A figura A22 apresenta os resultados da comparação entre os dias 28/01/2012 e 24/02/2012. Os resultados indicam que a maioria das áreas apresentou variações entre 0 e $-0,2$ m, com faixas esparsas apresentando valores acima de $0,2 \mathrm{~m}$. Os valores de variação mais negativos foram encontrados na região entre os perfis 2 e 3, na zona próxima ao início da vegetação, chegando a valores de $-0,4 \mathrm{~m}$. Os valores positivos máximos são encontrados nas proximidades do perfil 3, na porção próxima ao mar, com resultados chegando a $0,4 \mathrm{~m}$.

A figura A23 representa as diferenças altimétricas entre o dia 06/06/2011 e 26/02/2012. Os resultados indicam que quase a totalidade da área sofreu aumento nas altitudes, com destaque para região entre o limite norte e aproximadamente metade da distância entre o perfil 2 e o perfil 3, exibindo valores entre 0,15 e $0,45 \mathrm{~m}$. A região entre o limite norte e as adjacências do perfil 3 apresentou erosão na porção próxima a linha de 
vegetação exibindo valores entre $-0,05$ e $-0,65$, com destaque para as proximidades do perfil 2.

\subsection{2 - Coletas Diárias}

O único evento significativo que foi observado na escala diária ocorreu entre os dias 03/06/2011 e 06/06/2011, correspondendo a passagem de uma frente fria pela região da área de estudo. Durante os dias 4 e 5 de junho não foi possível coletar de dados devido as condições climáticas adversas a captação de sinal de satélites. As figuras A24 e A25 no Anexo I ilustram os resultados encontrados

A figura A24 faz referência a comparação de MDTs da Área Leste. Nesta figura pode se notar a tendência geral de erosão nos setores próximos a linha de vegetação e acresção nas áreas próximas a ação do mar. Observa-se uma intensificação da perda sedimentar na porção adjacente ao perfil 4, com valores na ordem $-0,5$ a $-0,7$. A porção que apresentou maiores diferenças altimétricas negativas se encontra no princípio do perfil 9, próxima a linha de vegetação, com valores de até $-0,9 \mathrm{~m}$. No entanto, tais valores devem estar superdimensionados devido a um erro de interpolação, este fato se explicaria por a área em questão se encontrar próxima aos limites de interpolação. Outro fator a contribuir com esta situação é a diferença das áreas amostradas nos dois levantamentos. Pois além da variação da maré atrapalhar nas nos caminhamentos, durante a coleta do dia 06/06 optou-se por cobrir áreas já pouco vegetadas que aparentaram ter sofrido erosão, como pode ser observado na figura 75 . 


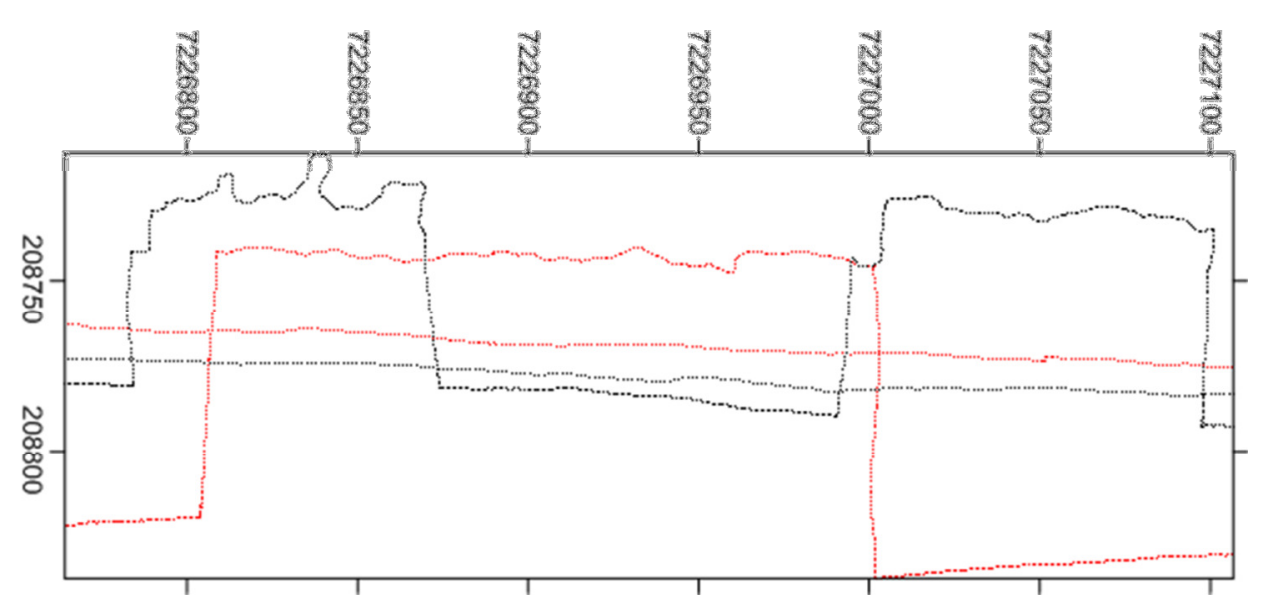

Figura 75: Detalhe dos dados coletados nos caminhamentos dos 03/06/2011(vermelho) e 06/06/2011 (preto). Notar a maior abrangência do levantamento do dia 06/06 no limite superior da figura.

$\mathrm{Na}$ figura A25 estão dispostos os resultados para a comparação da Área Sul. Observa-se que toda a porção próxima ao faixa de vegetação sofreu rebaixamento altimétrico, com destaque para a porção entre os perfis 15 e 16, apresentando valores de até $-0,65 \mathrm{~m}$.

\section{4 - Variação Volumétrica}

Devido ao erro associado aos dados topográficos, o cálculo de volume das superfícies obtidas acaba por ser muito prejudicado, não podendo ser encarado como uma grandeza quantitativa, visto que o erro associado se encontra na faixa de $1000 \mathrm{~m}^{3}$. Desta forma os resultados obtidos devem ser julgados como indicativos de tendências de processos sedimentares.

Nas figuras de 76 a 79 e nas tabelas 5 e 6 são representados os resultados referentes à Área Leste do Setor 2. Analisando as figuras 76 e 77 e a tabela 5 observa-se a ocorrência dos valores mais altos nos mês de fevereiro, e dos menores valores no mês de setembro. Também pode se observar a pequena variação entre os valores totais (soma dos volumes abaixo 
e acima da cota zero) e líquidos (somente volumes acima da cota zero). Através desses resultados pode se inferir uma tendência acresciva para a Área Leste, com a exceção do mês de setembro.

As figuras 78 e 79 e a tabela 6 apresentam os valores de variação mensal na Área Leste, obtidos através da subtração entre os volumes do primeiro dia de levantamento de um mês e dos volumes do último dia de levantamento do mês anterior. Na última coluna dos gráficos se encontra a comparação entre o dia 03/06/2011 e o dia 26/02/2012, respectivamente 0 primeiro e último levantamentos realizados.

Os resultados revelam acresção entre quase todos os meses, com exceção da comparação entre os meses de julho e agosto de 2011, e agosto e setembro de 2011, que apresentaram perda volumétrica, e a comparação entre dezembro de 2011 e janeiro de 2012, que não apresentou variações significativas. O maior ganho volumétrico aconteceu entre setembro e novembro de 2011 e a maior perda ocorreu entre agosto e setembro de 2011. A comparação entre junho de 2011 e fevereiro de 2012 reforça a tendência de aumento de volume observada nas figuras 76 e 77. 


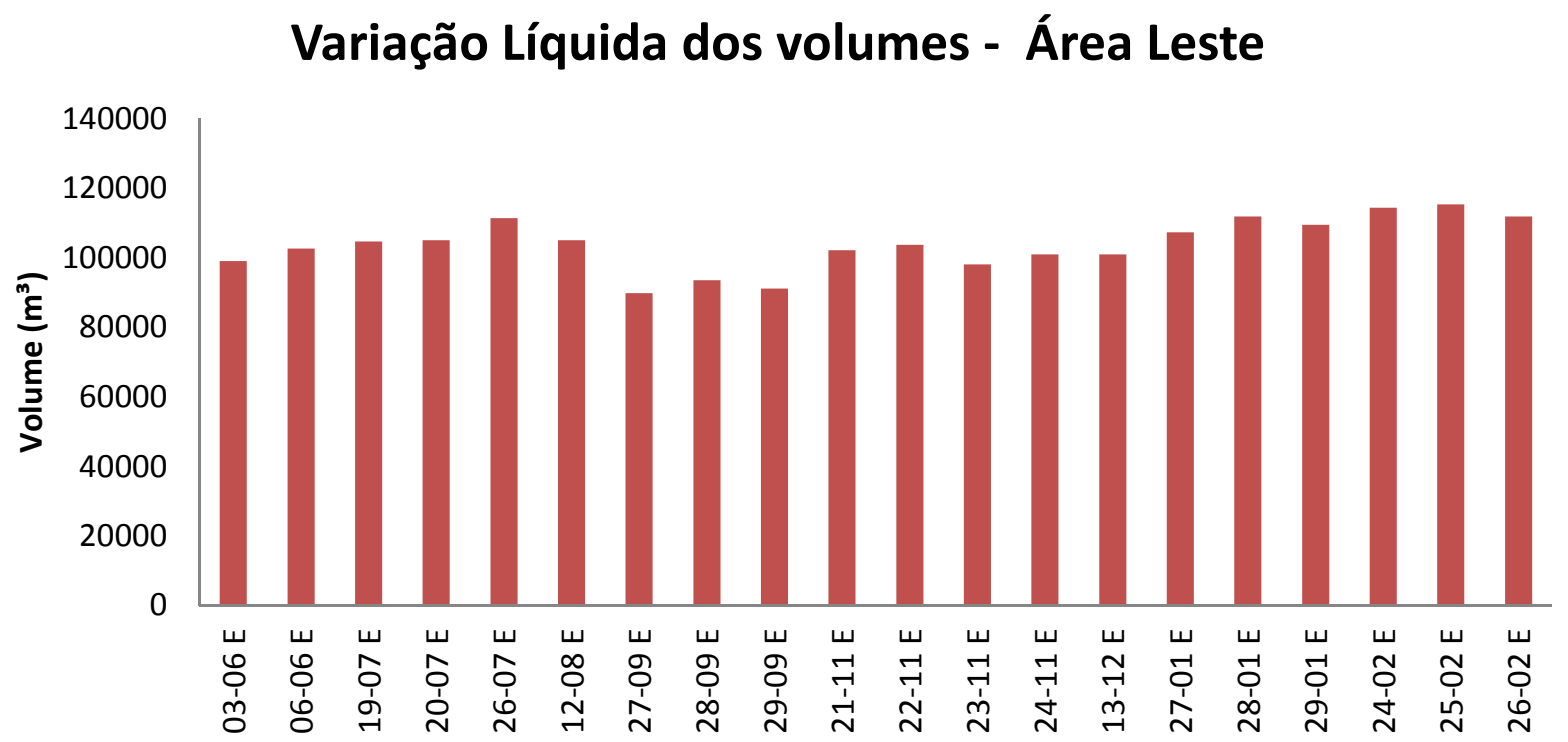

Figura 76: Variação líquida do volume na Área Leste do Setor 2 durante todo o período de levantamento.

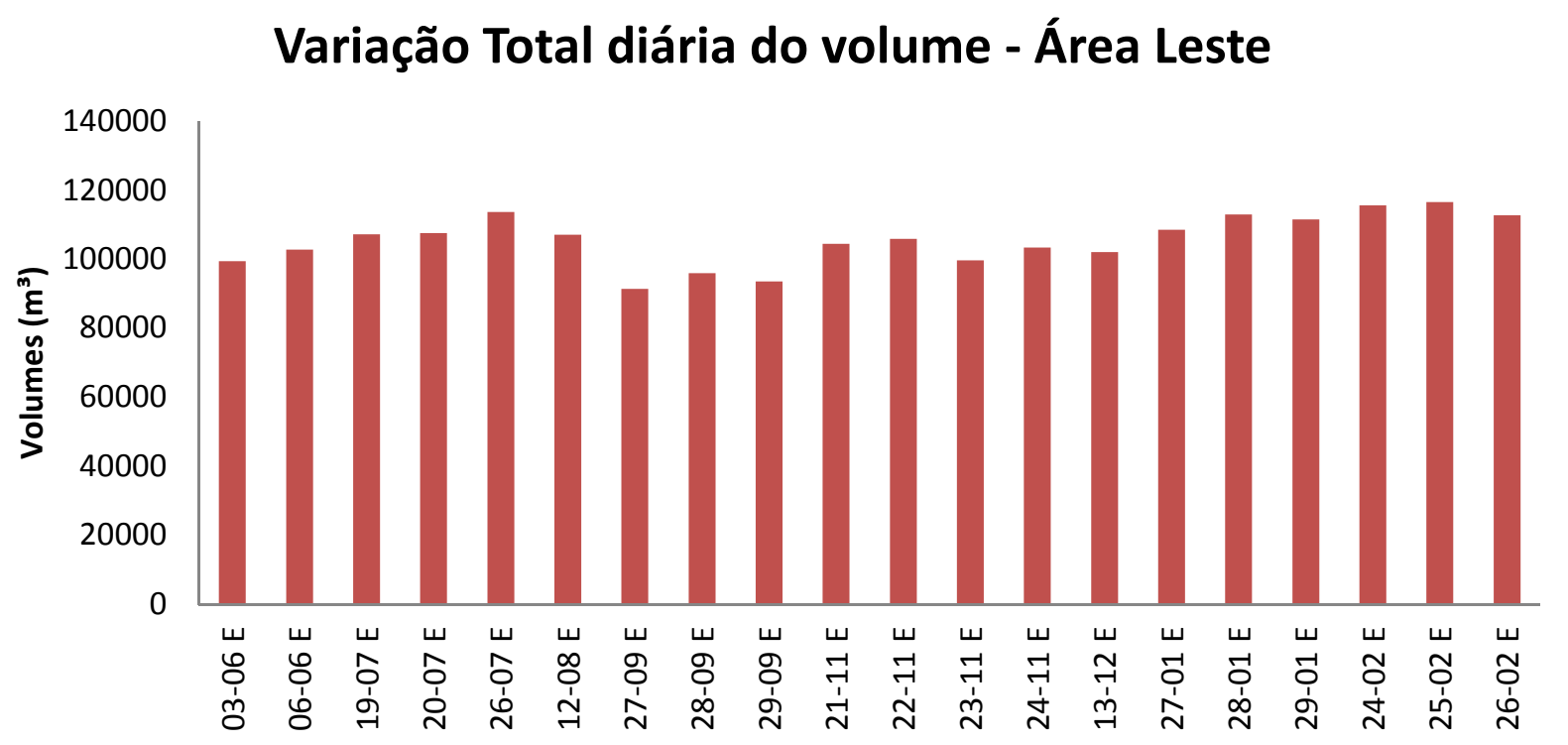

Figura 77: Variação total do volume na Área Leste do Setor 2 durante todo o período de levantamento. 


\begin{tabular}{|c|c|}
\hline Data & Volume Líquido \\
\hline $3 / 6 / 11$ & 99026.78 \\
\hline $6 / 6 / 11$ & 102661.06 \\
\hline $19 / 7 / 11$ & 104649.30 \\
\hline $20 / 7 / 11$ & 105078.65 \\
\hline $26 / 7 / 11$ & 111365.57 \\
\hline $12 / 8 / 11$ & 105107.52 \\
\hline $27 / 9 / 11$ & 89837.63 \\
\hline $28 / 9 / 11$ & 93557.14 \\
\hline $29 / 9 / 11$ & 91156.62 \\
\hline $21 / 11 / 11$ & 102223.45 \\
\hline $22 / 11 / 11$ & 103690.90 \\
\hline $23 / 11 / 11$ & 98125.28 \\
\hline $24 / 11 / 11$ & 100976.76 \\
\hline $13 / 12 / 11$ & 100942.56 \\
\hline $27 / 1 / 12$ & 107382.81 \\
\hline $28 / 1 / 12$ & 111904.58 \\
\hline $29 / 1 / 12$ & 109436.42 \\
\hline $24 / 2 / 12$ & 114364.56 \\
\hline $25 / 2 / 12$ & 115328.45 \\
\hline $26 / 2 / 12$ & 111841.26 \\
\hline
\end{tabular}

A

\begin{tabular}{|c|c|}
\hline Data & Volume Total \\
\hline $3 / 6 / 11$ & 99391.76 \\
\hline $6 / 6 / 11$ & 102772.87 \\
\hline $19 / 7 / 11$ & 107194.35 \\
\hline $20 / 7 / 11$ & 107564.12 \\
\hline $26 / 7 / 11$ & 113627.41 \\
\hline $12 / 8 / 11$ & 107068.83 \\
\hline $27 / 9 / 11$ & 91432.88 \\
\hline $28 / 9 / 11$ & 95930.17 \\
\hline $29 / 9 / 11$ & 93570.66 \\
\hline $21 / 11 / 11$ & 104489.69 \\
\hline $22 / 11 / 11$ & 105933.75 \\
\hline $23 / 11 / 11$ & 99688.98 \\
\hline $24 / 11 / 11$ & 103368.89 \\
\hline $13 / 12 / 11$ & 102092.86 \\
\hline $27 / 1 / 12$ & 108565.77 \\
\hline $28 / 1 / 12$ & 112995.67 \\
\hline $29 / 1 / 12$ & 111570.33 \\
\hline $24 / 2 / 12$ & 115626.66 \\
\hline $25 / 2 / 12$ & 116558.70 \\
\hline $26 / 2 / 12$ & 112728.69 \\
\hline
\end{tabular}

B

Tabela 5: Resultados dos volumes para todos os levantamentos executados na Área Leste do Setor 2. Da esquerda para direita, Tabela A: Volumes líquidos; Tabela B:

Volumes totais.

\section{Variação Líquida Mensal de Volume - Área Leste}

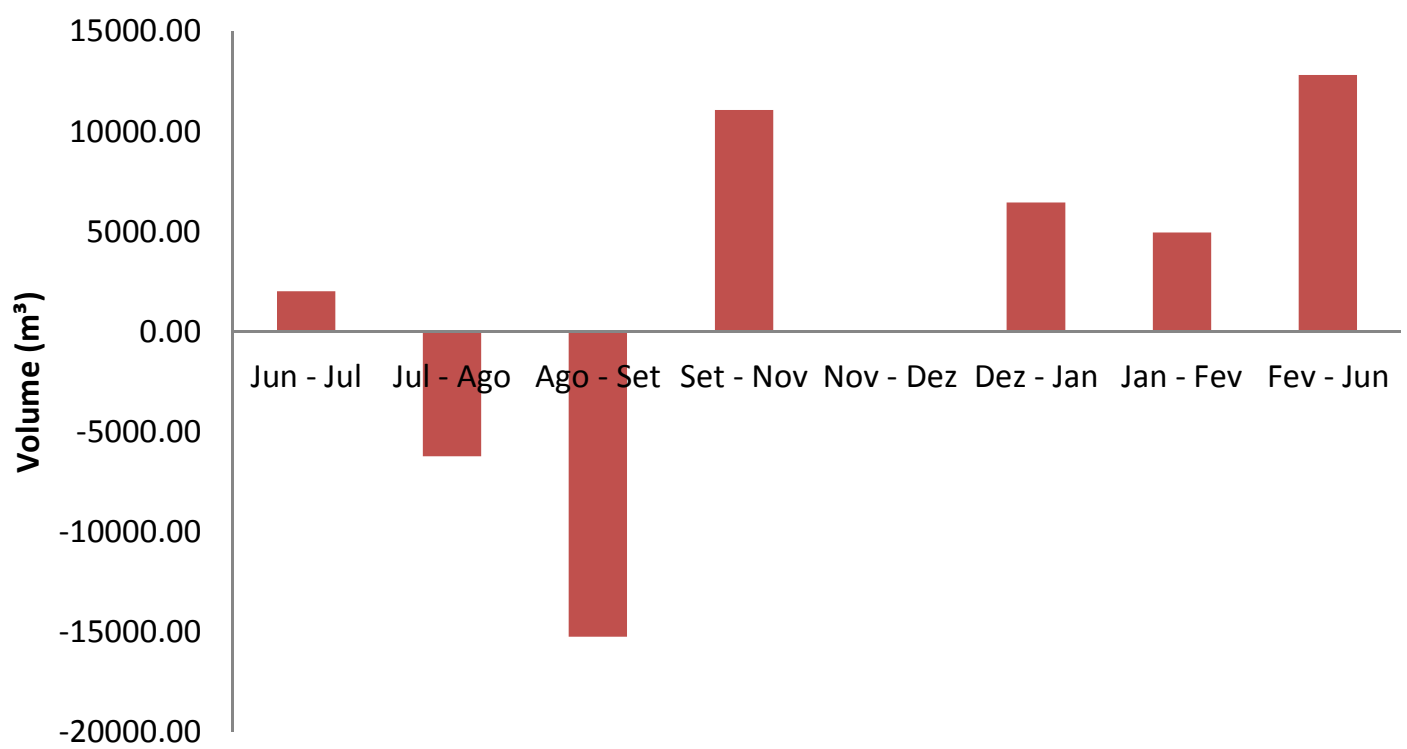

Figura 78: Variação mensal líquida de volume na Área Leste do Setor 2, valores em $\mathrm{m}^{3}$. 


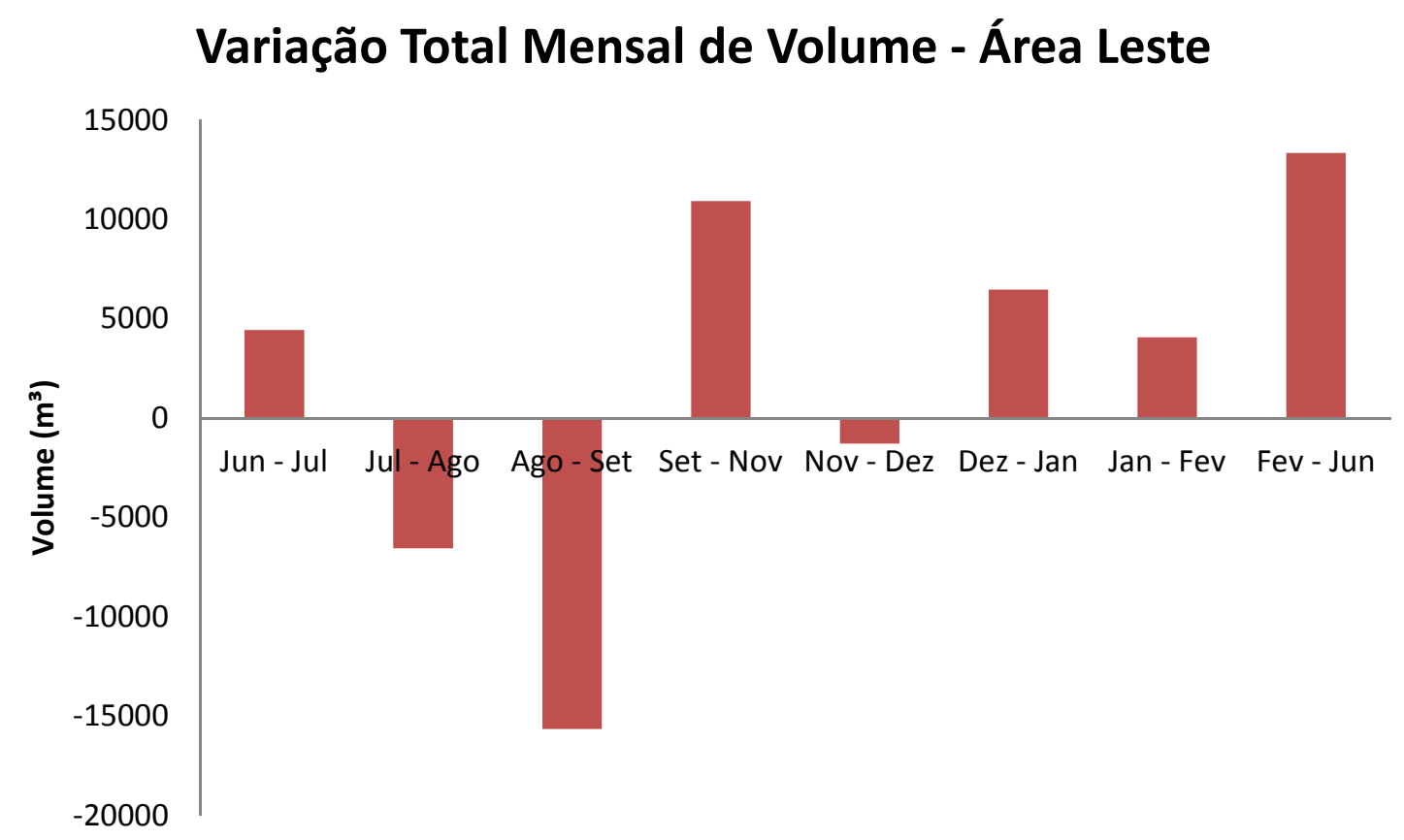

Figura 79: Variação mensal total de volume na Área Leste do Setor 2, valores em $\mathrm{m}^{3}$.

\begin{tabular}{|c|c|}
\hline Data & Volume \\
\hline Jun - Jul & 1988.25 \\
\hline Jul - Ago & -6258.05 \\
\hline Ago - Set & -15269.89 \\
\hline Set - Nov & 11066.83 \\
\hline Nov - Dez & -34.20 \\
\hline Dez - Jan & 6440.25 \\
\hline Jan - Fev & 4928.14 \\
\hline Fev - Jun & 12814.48 \\
\hline
\end{tabular}

A

\begin{tabular}{|c|c|}
\hline Data & Volume \\
\hline Jun - Jul & 4421.48 \\
\hline Jul - Ago & -6558.58 \\
\hline Ago - Set & -15635.95 \\
\hline Set - Nov & 10919.03 \\
\hline Nov - Dez & -1276.02 \\
\hline Dez - Jan & 6472.90 \\
\hline Jan - Fev & 4056.34 \\
\hline Fev - Jun & 13336.93 \\
\hline
\end{tabular}

B

Tabela 6: Variação mensal dos volumes durante os levantamentos executados na Área Leste do Setor 2. Da esquerda para direita, Tabela A: Volumes líquidos; Tabela B: Volumes totais.

Os resultados referentes a Área Sul do Setor 2 se encontram dispostos nas figuras 80 a 83 e nas tabelas 7 e 8 . Nas figuras 80 e 81 são apresentadas as variações diárias totais e líquidas, que diferiram significativamente, em contraste com os resultados da Área Leste. A variação líquida diária demonstrou uma perda crescente de volume, com os menores valores 
ocorrendo em fevereiro de 2012. A variação total diária revelou perdas volumétricas menores, com os menores valores ocorrendo em setembro de 2011. Situação mais análoga ao comportamento apresentado pela Área Leste.

Os resultados das variações mensais da Área Sul, tanto líquida como total, se encontram nas figuras 82 e 83 e na tabela 7 . As variações líquidas apresentaram variações pequenas positivas, na faixa do erro adotado, podendo ser tratadas em termos práticos como meses sem variação de volume. A comparação de volume total apresenta variações positivas significativas, com o período entre setembro e novembro de 2011 sendo o mais relevante, seguido pelo período entre janeiro e fevereiro de 2012. Nos dois gráficos a variação negativa mais acentuada ocorre entre agosto e setembro de 2011, sendo mais intensa na comparação líquida. De modo geral, as variações negativas foram mais intensas na comparação líquida, denotando uma tendência de transferência de sedimentos em direção aos níveis de menor altitude.

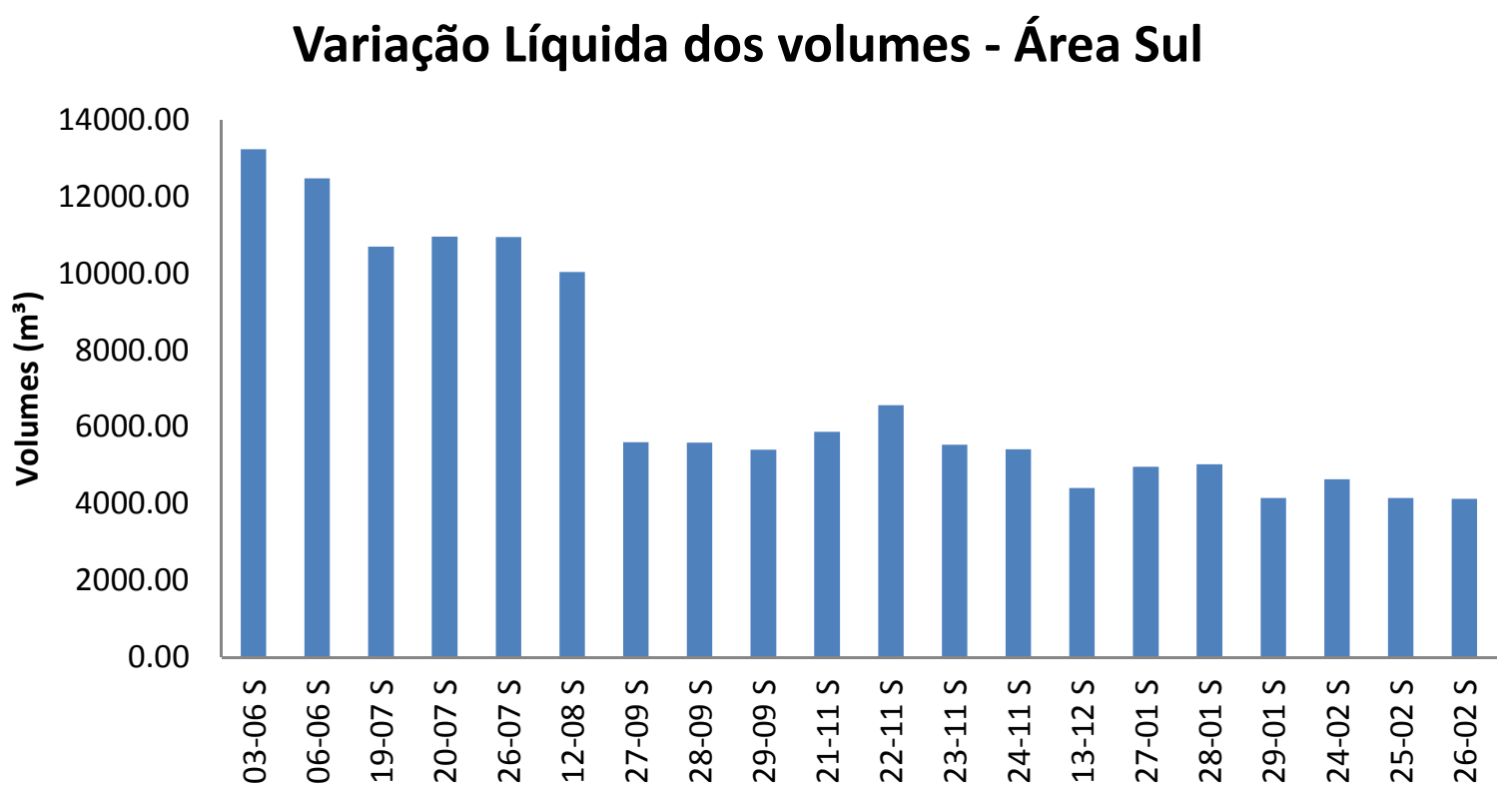

Figura 80: Variação líquida do volume na Área Sul do Setor 2 durante todo o período de levantamento. 


\section{Variação Total dos volumes - Área Sul}

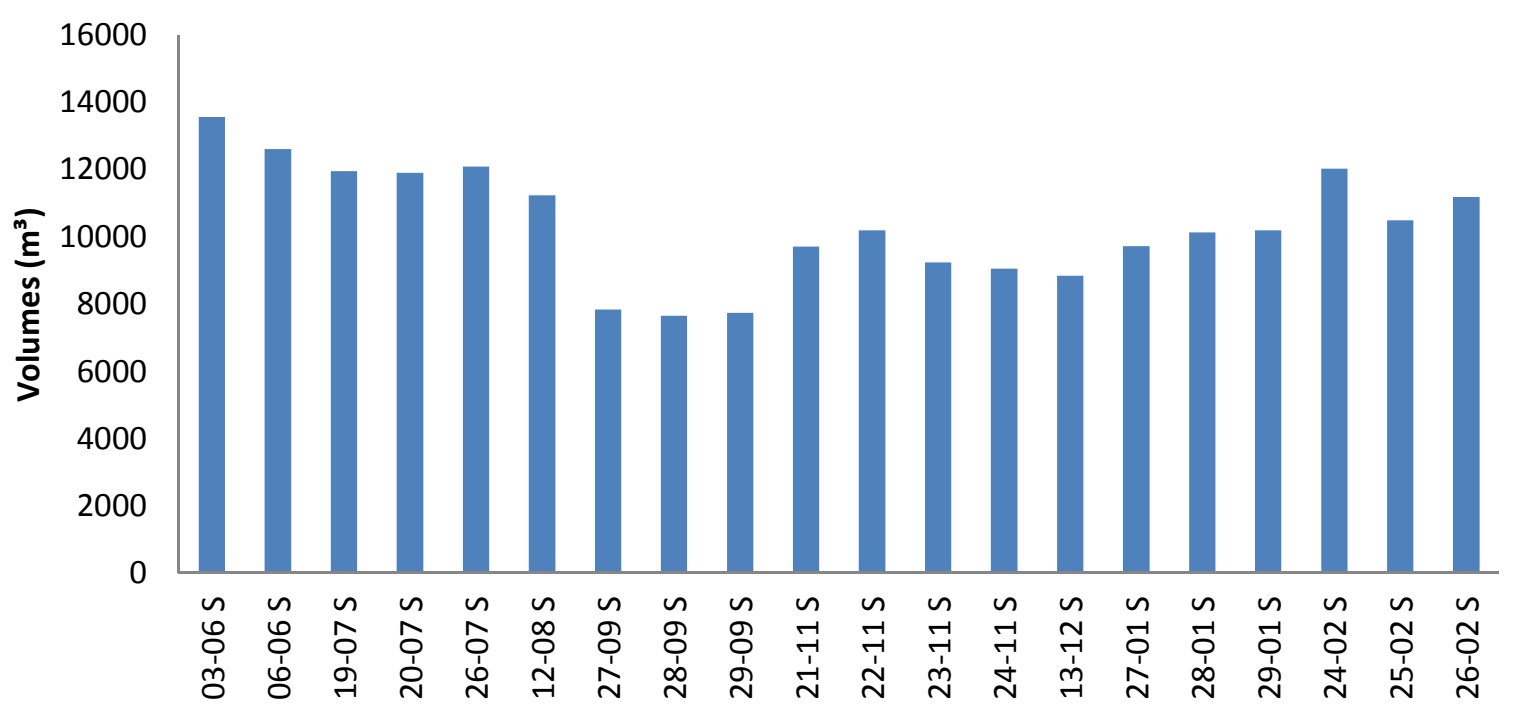

Figura 81: Variação total do volume na Área Sul do Setor 2 durante todo o período de levantamento.

\begin{tabular}{|c|c|}
\hline Data & Volume \\
\hline $3 / 6 / 2011$ & 13563.26 \\
\hline $6 / 6 / 2011$ & 12611.80 \\
$19 / 07 / 2011$ & 11956.64 \\
$20 / 07 / 2011$ & 11897.62 \\
$26 / 07 / 2011$ & 12087.67 \\
\hline $12 / 8 / 2011$ & 11237.08 \\
\hline $27 / 09 / 2011$ & 7835.75 \\
$28 / 09 / 2011$ & 7648.19 \\
$29 / 09 / 2011$ & 7739.71 \\
\hline $21 / 11 / 2011$ & 9708.03 \\
\hline $22 / 11 / 2011$ & 10194.08 \\
\hline $23 / 11 / 2011$ & 9241.63 \\
\hline $24 / 11 / 2011$ & 9050.48 \\
$13 / 12 / 2011$ & 8835.00 \\
$27 / 01 / 2012$ & 9723.07 \\
\hline $28 / 01 / 2012$ & 10128.23 \\
\hline $29 / 01 / 2012$ & 10196.19 \\
\hline $24 / 02 / 2012$ & 12029.65 \\
$25 / 02 / 2012$ & 10487.61 \\
$26 / 02 / 2012$ & 11187.52 \\
\hline
\end{tabular}

A

\begin{tabular}{|c|c|}
\hline Data & Volume \\
\hline $3 / 6 / 2011$ & 13244.48 \\
\hline $6 / 6 / 2011$ & 12488.18 \\
\hline $19 / 07 / 2011$ & 10710.12 \\
$20 / 07 / 2011$ & 10962.51 \\
$26 / 07 / 2011$ & 10956.95 \\
\hline $12 / 8 / 2011$ & 10043.83 \\
$27 / 09 / 2011$ & 5605.56 \\
$28 / 09 / 2011$ & 5597.32 \\
$29 / 09 / 2011$ & 5412.01 \\
\hline $21 / 11 / 2011$ & 5885.40 \\
\hline $22 / 11 / 2011$ & 6571.69 \\
\hline $23 / 11 / 2011$ & 5543.65 \\
\hline $24 / 11 / 2011$ & 5423.92 \\
$13 / 12 / 2011$ & 4417.30 \\
$27 / 01 / 2012$ & 4968.78 \\
\hline $28 / 01 / 2012$ & 5034.35 \\
\hline $29 / 01 / 2012$ & 4160.17 \\
$24 / 02 / 2012$ & 4641.47 \\
$25 / 02 / 2012$ & 4155.22 \\
$26 / 02 / 2012$ & 4133.81 \\
\hline
\end{tabular}

B

Tabela 7: Resultados dos volumes para todos os levantamentos executados na Área Sul do Setor 2. Da esquerda para direita, Tabela A: Volumes líquidos; Tabela B: Volumes totais. 


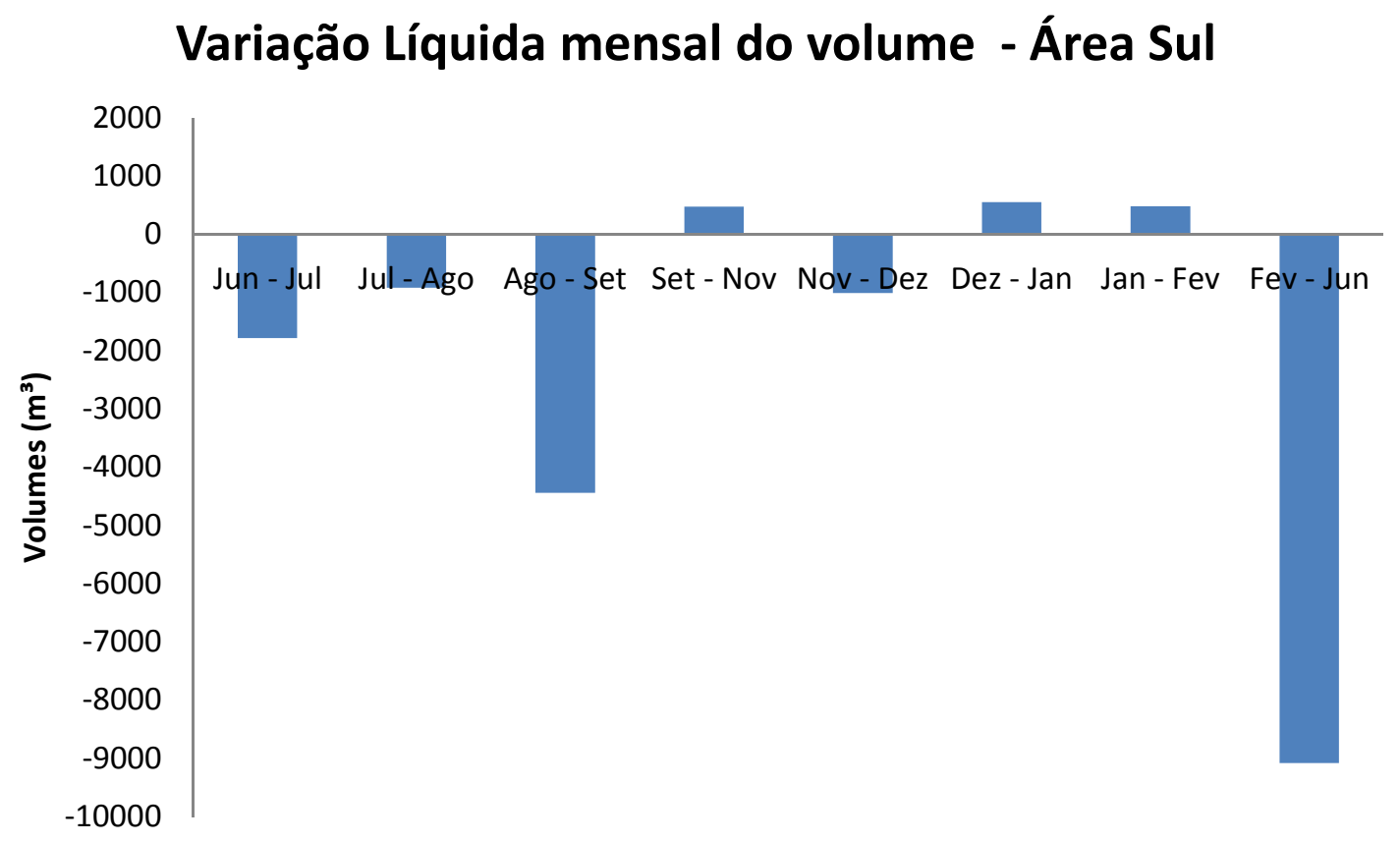

Figura 82: Variação mensal líquida de volume na Área Sul do Setor 2, valores em $\mathrm{m}^{3}$.

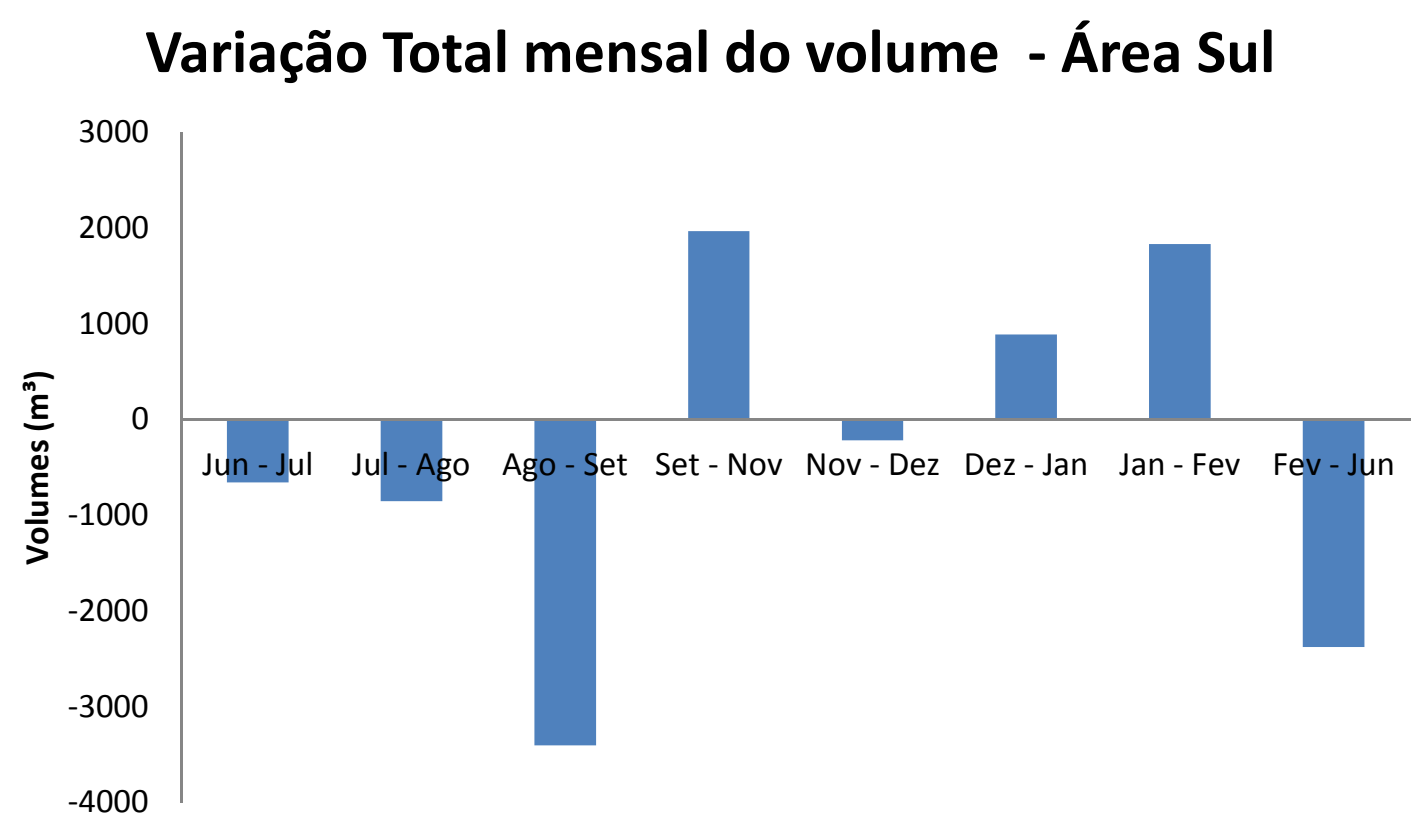

Figura 83: Variação mensal total de volume na Área Sul do Setor 2, valores em $\mathrm{m}^{3}$. 


\begin{tabular}{|c|c|}
\hline Data & Volume \\
\hline Jun - Jul & -1778.06 \\
\hline Jul - Ago & -913.12 \\
\hline Ago - Set & -4438.27 \\
\hline Set - Nov & 473.39 \\
\hline Nov - Dez & -1006.62 \\
\hline Dez - Jan & 551.48 \\
\hline Jan - Fev & 481.30 \\
\hline Fev - Jun & -9076.00 \\
\hline
\end{tabular}

A

\begin{tabular}{|c|c|}
\hline Data & Volume \\
\hline Jun - Jul & -655.16 \\
\hline Jul - Ago & -850.59 \\
\hline Ago - Set & -3401.32 \\
\hline Set - Nov & 1968.32 \\
\hline Nov - Dez & -215.47 \\
\hline Dez - Jan & 888.06 \\
\hline Jan - Fev & 1833.46 \\
\hline Fev - Jun & -2375.74 \\
\hline
\end{tabular}

B

Tabela 8: Variação mensal dos volumes durante os levantamentos executados na Área Sul do Setor 2. Da esquerda para direita, Tabela X: Volumes líquidos; Tabela Y: Volumes totais.

As figuras 84 e 85 e a tabela 9 tratam dos resultados da variação volumétrica do Setor 1. Devido a logística adotada durante as saídas de campo, a maioria dos levantamentos foram executados em condições de maré cheia, resultando em MDTs com dados concentrados acima da cota zero, inviabilizando o cálculo de volumes totais.

Analisando a figura 84 , nota-se que o comportamento volumétrico do Setor 1 é semelhante ao apresentado pela Área Leste, com os maiores valores ocorrendo no mês de fevereiro de 2012, e com os menores valores concentrados no mês de setembro de 2011, resultando em uma tendência geral de acresção dos volumes.

A tendência da variação mensal também se mostrou similar a observada na Área Leste, com as variações mais negativas ocorrendo na comparação entre julho e setembro de 2011 ; lembrando que não houve coleta no mês de agosto nesse setor; e a variação positiva mais intensa acontecendo entre setembro e novembro de 2011. A comparação entre fevereiro de 2012 e junho de 2011 também demonstrou um acentuado ganho sedimentar, reforçando a tendência acresciva indicada na comparação diária. 


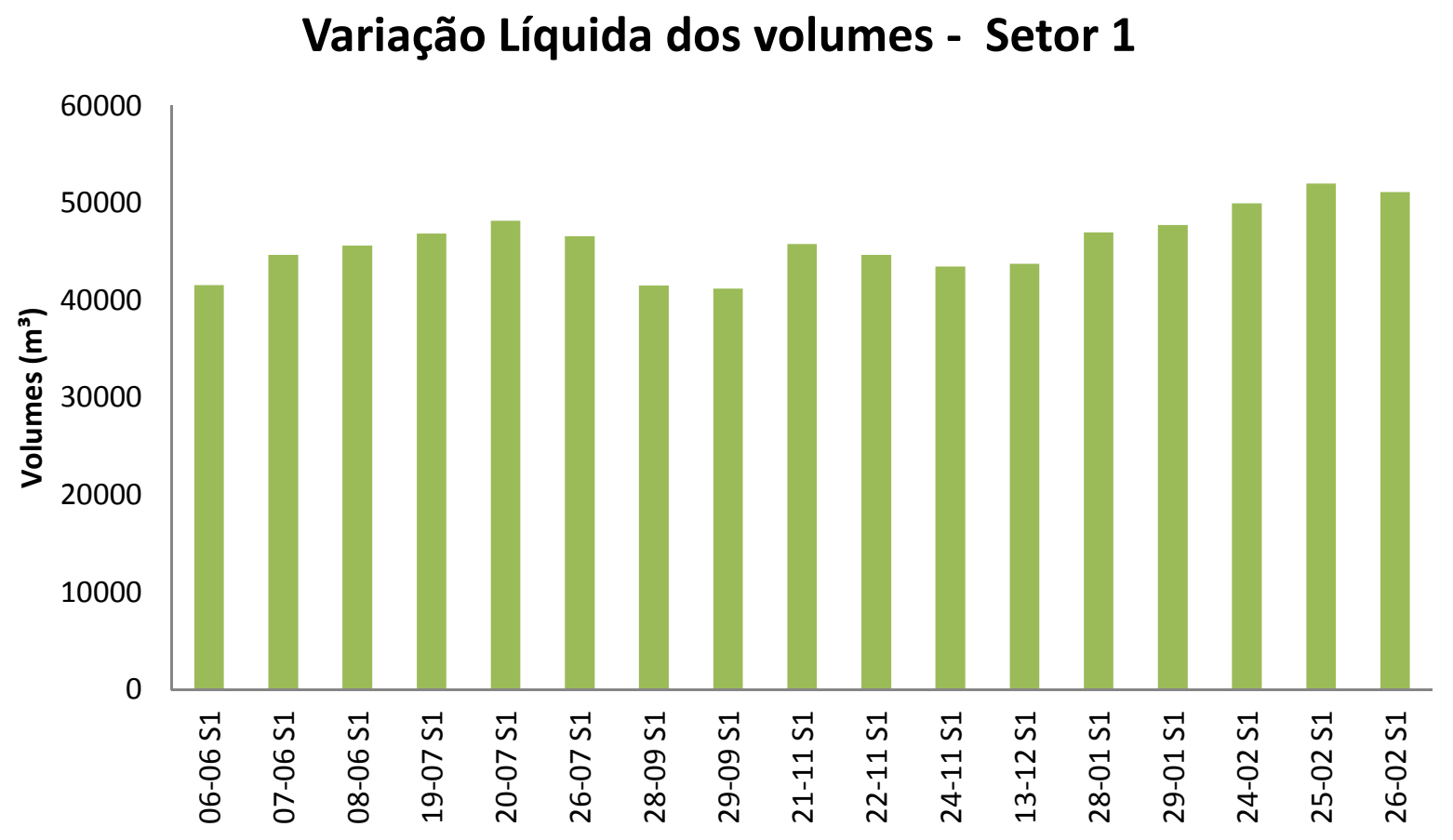

Figura 84: Variação líquida diária do volume do Setor 1, valores em $\mathrm{m}^{3}$.

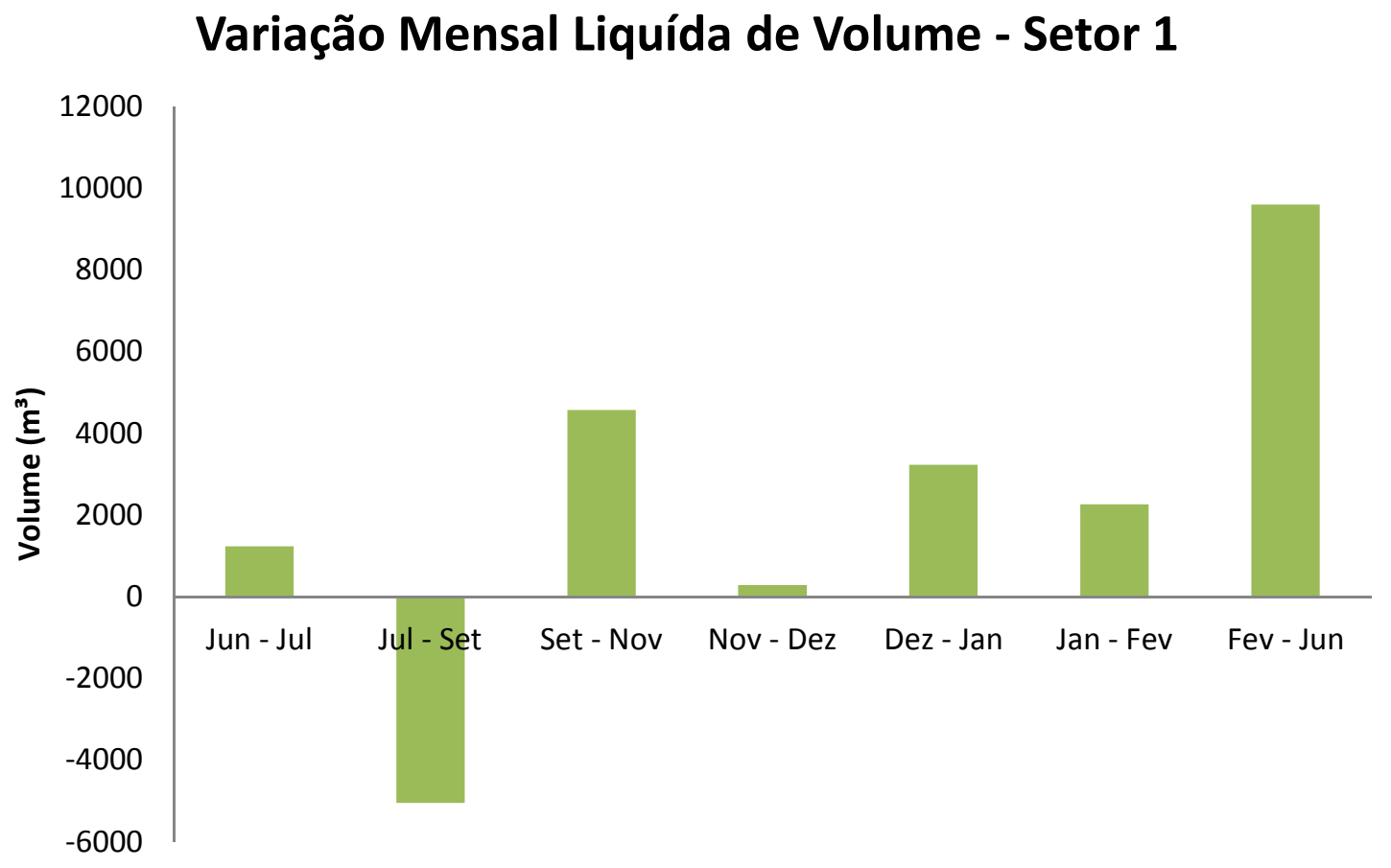

Figura 85: Variação diária líquida de volume do Setor 2, valores em $\mathrm{m}^{3}$. 


\begin{tabular}{|c|c|}
\hline Data & Volume \\
\hline $6 / 6 / 11$ & 41549.33 \\
\hline $6 / 7 / 11$ & 44672.2 \\
\hline $8 / 6 / 11$ & 45622.12 \\
\hline $19 / 7 / 11$ & 46848.12 \\
\hline $20 / 7 / 11$ & 48195.62 \\
\hline $26 / 7 / 11$ & 46595.92 \\
\hline $28 / 9 / 11$ & 41545.88 \\
\hline $29 / 9 / 11$ & 41218.27 \\
\hline $21 / 11 / 11$ & 45784.96 \\
\hline $22 / 11 / 11$ & 44683.43 \\
\hline $24 / 11 / 11$ & 43493.87 \\
\hline $13 / 12 / 11$ & 43778.33 \\
\hline $28 / 1 / 12$ & 47001.69 \\
\hline $29 / 1 / 12$ & 47732.58 \\
\hline $24 / 2 / 12$ & 49985.71 \\
\hline $25 / 2 / 12$ & 52020.26 \\
\hline $26 / 2 / 12$ & 51142.53 \\
\hline
\end{tabular}

A

\begin{tabular}{|c|c|}
\hline Data & Volume \\
\hline Jun - Jul & 1226.00 \\
\hline Jul - Set & -5050.04 \\
\hline Set - Nov & 4566.69 \\
\hline Nov - Dez & 284.46 \\
\hline Dez - Jan & 3223.37 \\
\hline Jan - Fev & 2253.13 \\
\hline Fev - Jun & 9593.21 \\
\hline
\end{tabular}

B

Tabela 9: (da esquerda para direita) Tabela A: Variação diária dos volumes do Setor 1, Tabela B: Variação mensal dos volumes do Setor 1 , valores em $\mathrm{m}^{3}$.

\section{5 - Simulações do SMC}

Os casos propagados no módulo Mopla foram definidos com base na análise dos dados de ondulações em águas profundas obtidos para o período de campanhas a campo. Devido a já mencionada falta de dados, o objetivo das simulações numéricas foi de se obter uma caracterização qualitativa geral da interação entre as feições costeiras localizadas na área de estudo e os trens de ondas provindos de distintas direções.

Optou-se em realizar as simulações em um intervalo entre $50^{\circ}$ e $230^{\circ}$ de direções de onda, com a execução de 3 malhas distintas, contemplado as direções dos quadrantes E, SE e S. A tabela 10 sumariza os casos selecionados e suas características básicas: altura, período, direção e profundidade inicial. Os resultados estão expostos na maneira de gráficos com 
os vetores de direção de onda sobre um campo de magnitude de alturas, estando localizadas as figuras no Anexo II.

Deve se ressaltar que os resultados estão superestimados na área que sofre influência do molhe hidráulico causado pela presença da Desembocadura de Cananéia. A presença do molhe ainda acarreta difração dos trens de onda, criando um padrão mais complexo do que o apresentado nos resultados.

Na figura 86 está delimitada a área onde se encontram os bancos de areia sobre a batimetria utilizada, associados à ação direta da Desembocadura. Dentro desta porção as alturas de onda certamente são menores que as demonstradas nos resultados, no entanto a influência da desembocadura varia com as condições de maré e aporte de água doce. Com intuito de se diminuir este erro, foi utilizada em todas as propagações a amplitude de maré $2,2 \mathrm{~m}$, correspondendo a maré máxima de sizígia (Mesquita \& Harari,1983) mais a maré meteorológica de $1 \mathrm{~m}$. Segundo Conti et al. (2012), esta situação corresponde a atuação de frentes frias na região de estudo, sendo a ocasião em que as correntes de maré mais perdem força no canal da desembocadura. 


\begin{tabular}{cccccc|}
\hline Caso & Direção & $\mathbf{H}$ & $\mathbf{T}$ & Prof & $\boldsymbol{Y}$ \\
\hline E11 & 56,76 & 2,5 & 8 & 25.15 & 3,3 \\
\hline E04 & 63,89 & 2,5 & 8 & 25.15 & 3,3 \\
\hline E18 & 72,4 & 2 & 8 & 25.15 & 3,3 \\
\hline E17 & 80 & 2,5 & 8 & 25.15 & 3,3 \\
\hline E19 & 90 & 2 & 8 & 25.15 & 3,3 \\
\hline E 15 & 106,7 & 2 & 8 & 25.15 & 3,3 \\
\hline SE 11 & 115.5 & 5 & 14 & 25.15 & 10 \\
\hline SE 07 & 122,1 & 4 & 14 & 25.15 & 10 \\
\hline SE 15 & 131,51 & 4 & 14 & 25.15 & 10 \\
\hline SE 09 & 141,62 & 4 & 14 & 25.15 & 10 \\
\hline SE 04 & 152,8 & 4 & 14 & 25.15 & 10 \\
\hline S 05 & 161,14 & 5 & 14 & 20 & 10 \\
\hline S 24 & 170 & 4 & 14 & 20 & 10 \\
\hline S 04 & 183.406 & 4 & 14 & 20 & 10 \\
\hline S 06 & 191.923 & 4 & 14 & 20 & 10 \\
\hline S 07 & 206,23 & 4 & 14 & 20 & 10 \\
\hline S 22 & 200 & 4 & 10 & 20 & 9 \\
\hline S 16 & 214,67 & 5 & 14 & 20 & 10 \\
\hline S 23 & 226.347 & 4 & 10 & 20 & 9 \\
\hline
\end{tabular}

Tabela 10: Resumo dos casos selecionados e seus respectivos parâmetros. Valores de direção em graus, altura de onda (H) em metros, períodos de ondas (T) em segundos e profundidade inicial da onda (Prof) em metros.

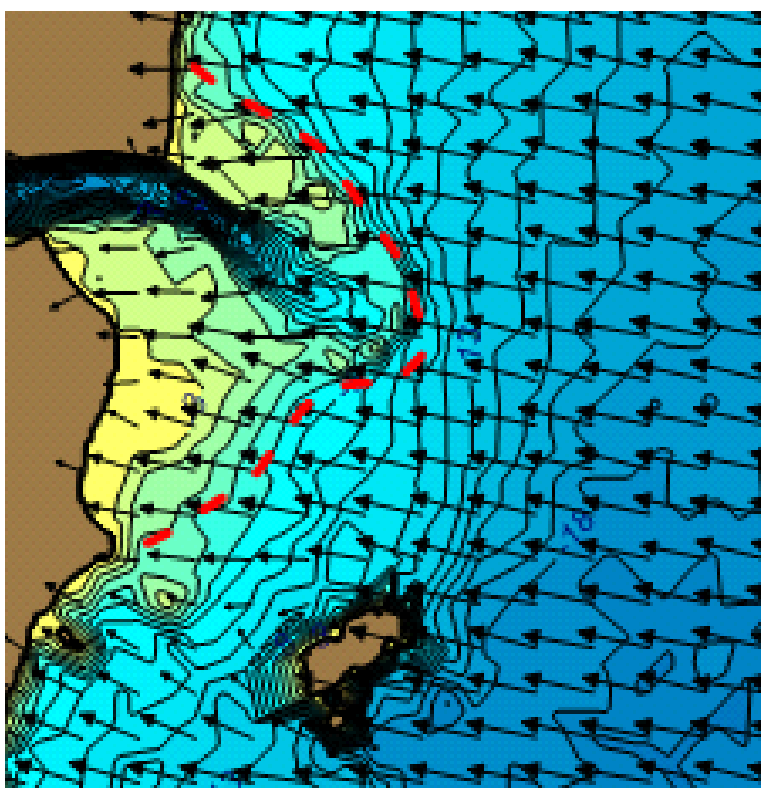

Figura 86: Área de influência da Desembocadura de Cananéia delimitada pela linha vermelha pontilhada. Notar os bancos areia dispostos entorno da saída da desembocadura. 
As ondulações provindas dos quadrantes ENE, NE e E incidem diretamente sobre a linha de costa da região, como observado nas figuras de B1 a B6, encontrando barreiras somente nos bancos de areia ao largo da saída da desembocadura. O canal da desembocadura parece estar bem abrigado de ondas provindas dessas direções, visto que normalmente as ondulações provindas dessas direções são menos intensas, associadas a condições de tempo bom, intensificando o efeito atenuador do fluxo provindo da Desembocadura.

Os resultados alcançados evidenciam a influência da llha do Bom Abrigo, que exerce um bloqueio sobre as ondas incidentes de SE, SSE, SSW, e SW (figuras B7 a B18). Contudo seu efeito parece ser restrito as adjacências da Desembocadura de Cananéia. O efeito de sombra no Pontal de Fora de llha Comprida e na área do canal é mais pronunciado nas ondas provenientes das direções entre $115^{\circ}$ até $152^{\circ}$ (figuras B7 a B11). A partir da direção de $162^{\circ}$ nota-se um maior poder de penetração dos trens de onda, com destaque para as direções entre $170^{\circ}$ e $190^{\circ}$.

Nas figuras B16 a B18 é possível observar a progressiva concentração da incidência das ondulações na llha do Cardoso, no canal e nas adjacências da Desembocadura, ficando as áreas mais ao norte menos afetadas pela ação das ondas. A figura B18 expõe os resultados para as ondulações provenientes da direção de $226,35^{\circ}$, que pode ser encarada como limite prático para incidência de ondas na área de estudo, ou seja, em termos práticos a orientação geral da costa não permite que ondulações provenientes de direções mais a W exerçam sua influência. 


\section{6 - Determinação das Cotas de Inundação}

Os caos definidos e os resultados alcançados na aplicação metodologia adotada para determinação das cotas de inundação se encontram sintetizados na tabela 11. Os casos 5 e 6 correspondem a previsão da cota de inundação após 50 anos de aceleração aumento do nível mar. O caso 5 diz respeito ao cenário otimista exposto em IPCC (2007), sendo correspondente a uma elevação de $0,005 \mathrm{~m} / \mathrm{ano}$. $\mathrm{O}$ caso 6 corresponde a elevação de 0,010 m/ano, sendo está a previsão crítica do relatório.

\begin{tabular}{|lcccc|}
\hline Casos & $\begin{array}{c}\text { Maré Astronômica } \\
\text { (Mesquita \& Harari, 1983) }\end{array}$ & $\begin{array}{c}\text { Maré Meteorolôgica } \\
\text { (Campos et al., 2010) }\end{array}$ & $\begin{array}{c}\text { Maré Meteorológica } \\
\text { (Parise et a l., 2009) }\end{array}$ & $\begin{array}{c}\text { Elevação Adicional do } \\
\text { Nivel do Mar (IPCC, 2007) }\end{array}$ \\
\hline Caso 1 & 1.02 & 0.38 & - & - \\
\hline Taso 2 & 1.02 & 1 & - & - \\
\hline Caso 3 & 1.02 & - & 1.45 & - \\
\hline Caso 4 & 1.02 & - & 1.94 & - \\
\hline Caso 5 & 1.02 & - & - & $0.25(5 \mathrm{~mm} / \mathrm{ano})$ \\
\hline Caso 6 & 1.02 & - & - & $0.5(10 \mathrm{~mm} / \mathrm{ano})$ \\
\hline
\end{tabular}

Tabela 11: Valores utilizados para obtenção das cotas de inundação. Valores de maré corrigidos para o datum do IBGE. Valores em metros.

A área do MDT interpolada com os dados do modelo digital de terreno global do software Goggle Earth ${ }^{\circledast}$ certamente exibe maiores cotas do que as obtidas. No entanto, durante as campanhas a campo procurou-se aquisitar a maiores elevações dos cordões litorâneos dispostos no pós-praia. Desta forma as áreas onde foram utilizados os dados do modelo global como áreas pouco elevadas, sujeitas a riscos de inundação. A figura 87 apresenta os dados utilizados na elaboração do MDT. 


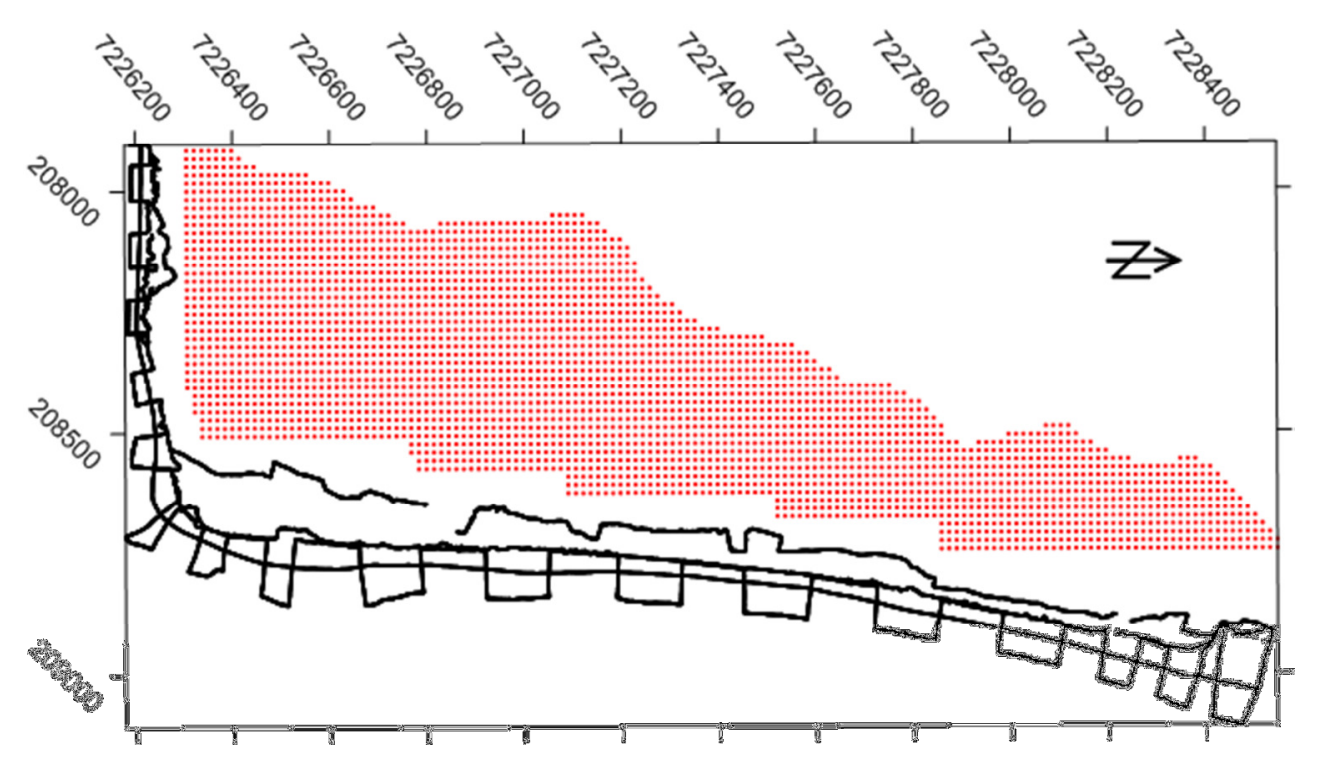

Figura 87: Dados utilizados na cofecção do MDT. Pontos Pretos - dados coletados em campo; Pontos Vermelhos - dados do modelo digital de elevação global do software Goggle Earth ${ }^{\circledR}$.

As figuras 88 a 93 ilustram os resultados obtidos pela sobreposição dos resultados dos casos ao MDT adotado. A figura 88 apresenta os resultados referentes ao Caso 1, que corresponde ao menor efeito de elevação do NRM causado por uma maré meteorológica.

A elevação do nível do mar de 1,4 $\mathrm{m}$ atingiu o começo da linha da vegetação em praticamente toda a área estudada. Os maiores impactos são observados na região adjacente a curva fisiográfica, especialmente nas proximidades da coordenada 208400 E. Na porção mais ao norte é possível notar a influência do curso d'água que desagua na face praial. 


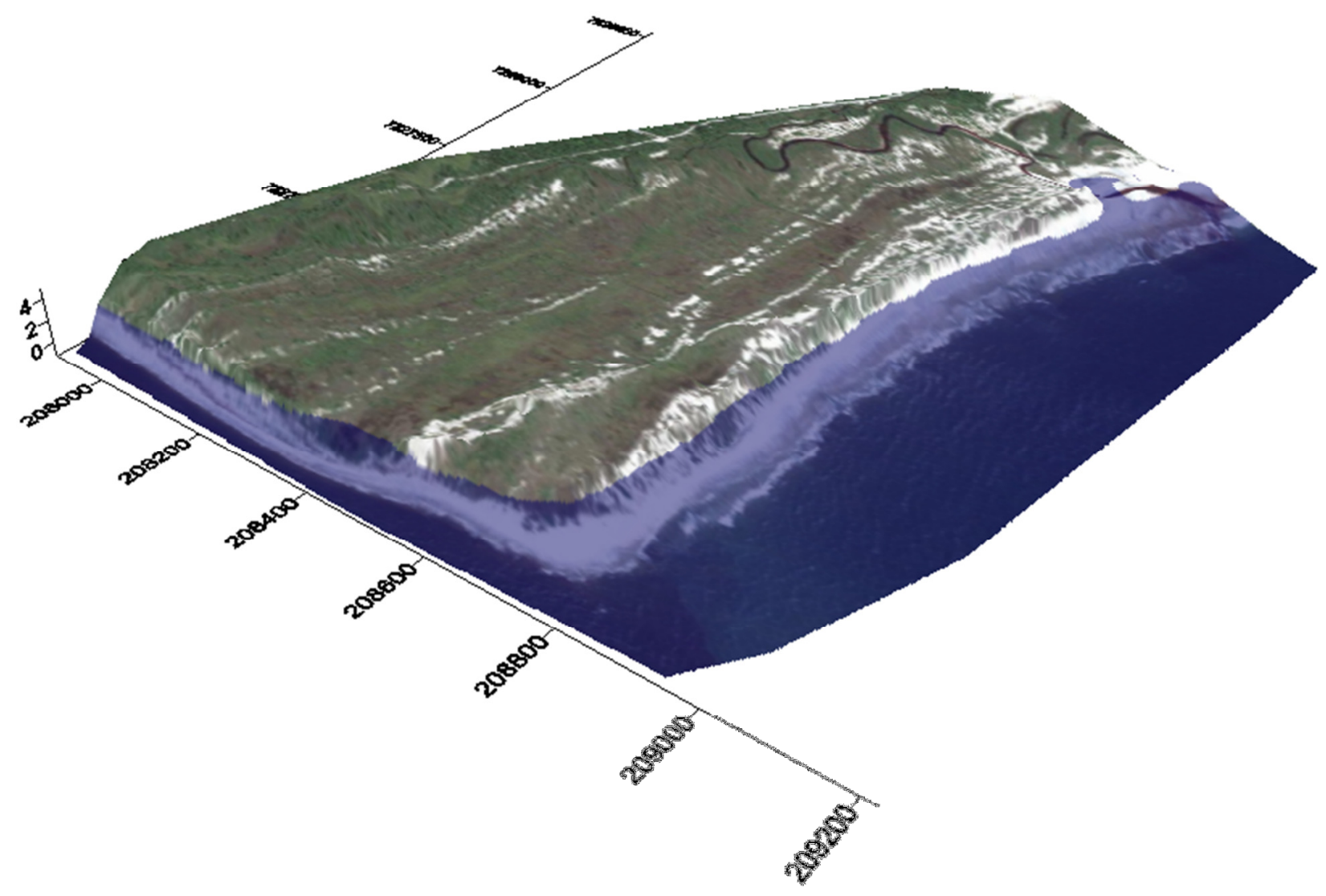

Figura 88: Elevação do mar de 1,4 m sobreposto ao MDT (Caso 1).

Na figura 89 estão apresentados os resultados referentes ao Caso 2, que representa uma elevação de cerca de $2 \mathrm{~m}$. É possível observar-se uma grande área com potencial risco de alagamento sobre a quase totalidade dos cordões litorâneos. O início desta área parece ser nas proximidades da coordenada 208400 E. São observados também alguns pontos de alagamento nas porções iniciais da zona vegetada, além de toda a área de influência do rio estar sobre efeito da elevação adicional do nível do mar. 


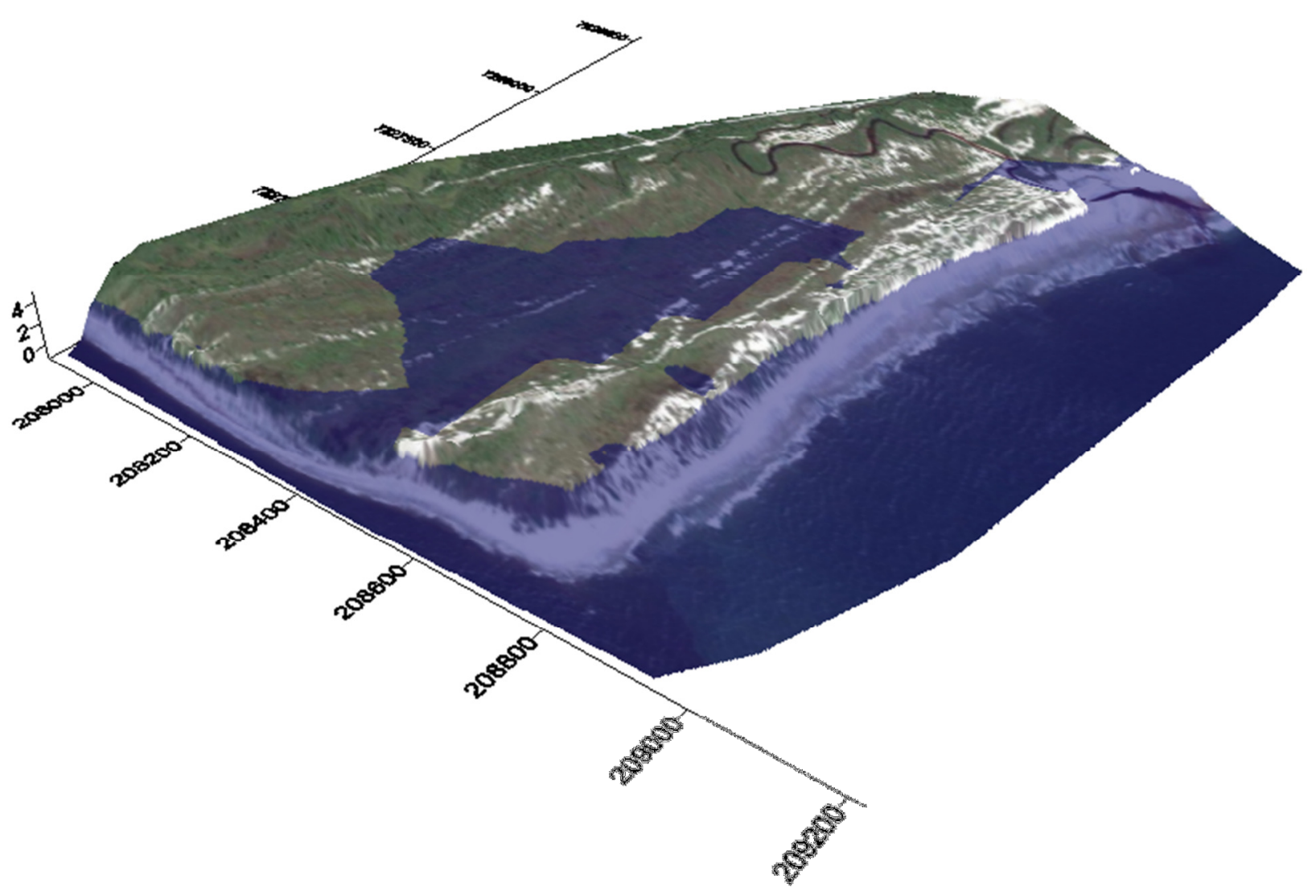

Figura 89: Elevação do mar de 2.02 m sobreposto ao MDT (Caso 2).

A figura 90 faz referencia aos resultados obtidos para o Caso 3, ou seja, a sobreposição de uma elevação do NRM de 2,47 m. Pode se observar uma intensificação do padrão identificado para o Caso 2. A região nas proximidades da coordenada 208400 E se encontra totalmente alagada e boa parte da zona inicial da área vegetada também se encontra sob efeito da ação das águas marinhas. $\mathrm{Na}$ área mais ao norte $\mathrm{o}$ alcance do mar também se intensificou. 


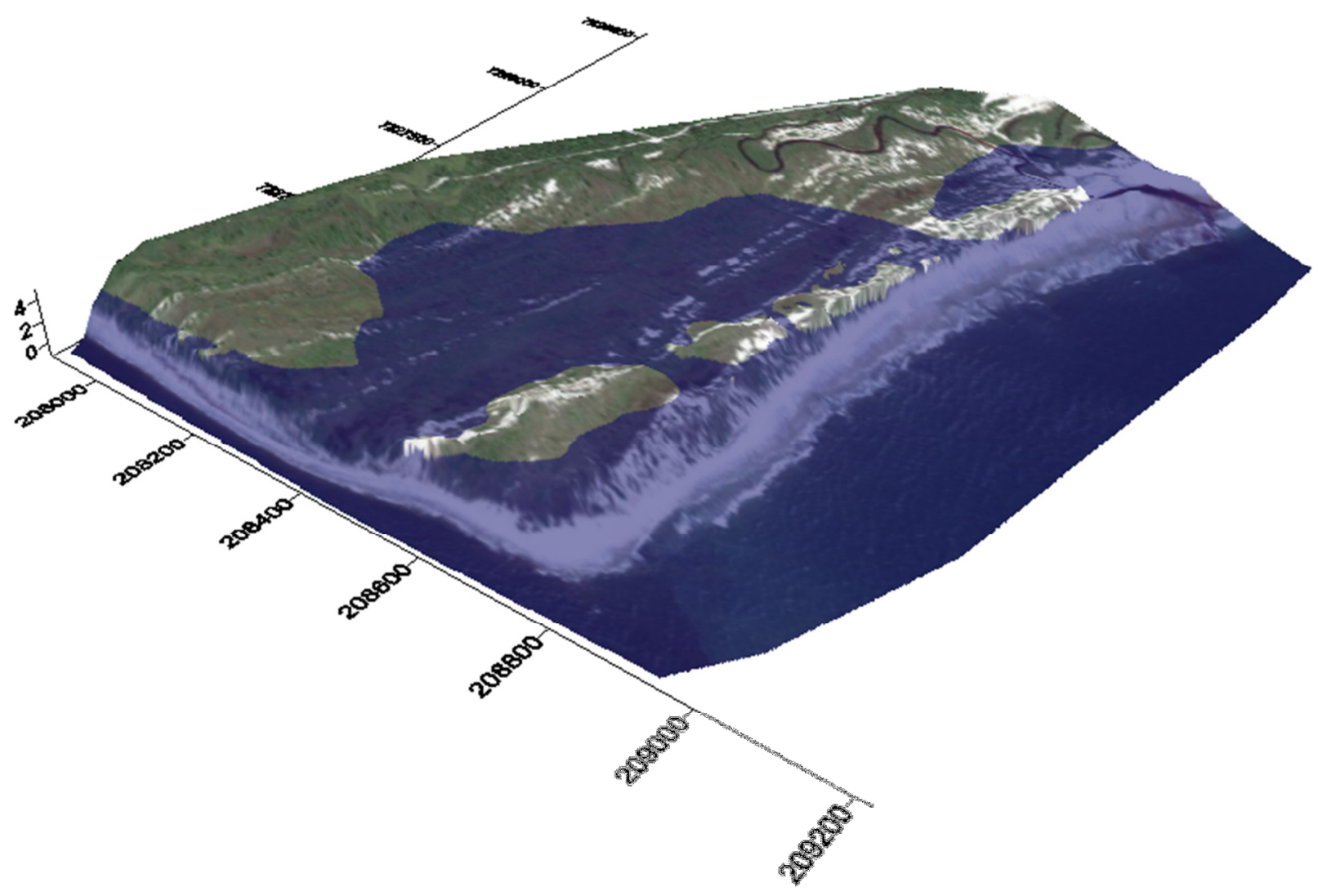

Figura 90: Elevação do mar de $2.47 \mathrm{~m}$ sobreposto ao MDT (Caso 3).

Os resultados obtidos para o Caso 4 se encontram apresentados na figura 91, sendo referentes a uma elevação de cerca de 3 m do NRM. Nesta análise praticamente toda a área de interesse foi alagada. Somente alguns pontos mais elevados, correspondentes ao cordão litorâneo mais conspícuo, se encontram emersos. Em termos práticos toda a área analisada pode ser considerada como sujeita a risco de alagamento. Os valores adotados no Caso 5 devem ser encarados como situações extremas, associados a eventos extremos com grande período de retorno.

As mudanças climáticas globais podem intensificar e tornar mais frequentes os eventos atmosféricos extremos, tornando mais comuns os eventos de marés meteorológicas. A área mais afetada pelas inundações é quase totalmente composta de sedimentos arenosos friáveis depositados na 
forma de testemunhos dos antigos cordões litorâneos, formados pela ação da dinâmica costeira. A modificação dos processos costeiros atuais muito provavelmente acarretará em uma redistribuição sedimentar e a consequente erosão dessas feições.

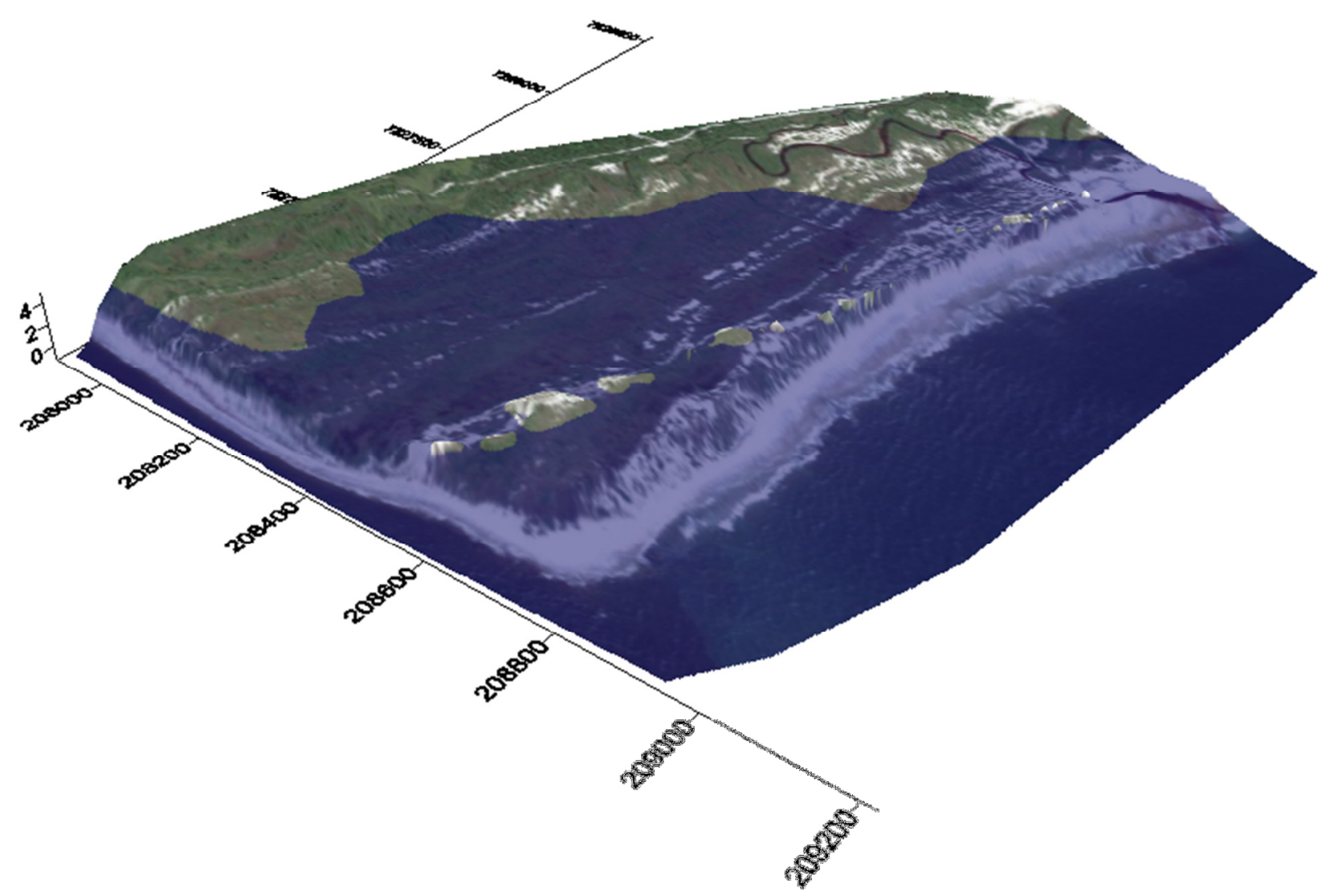

Figura 91: Elevação do mar de 2.96 m sobreposto ao MDT (Caso 4).

As figuras 92 e 93 apresentam os resultados dos Casos 5 e 6 , referentes aos cenários de elevação do NRM propostos por IPCC (2007). Sob os seus efeitos a área de interesse demonstrou comportamento similar ao apresentado nos resultados do Caso 1 , com os maiores impactos sendo observados nas adjacências da curva fisiográfica associada a Desembocadura de Cananéia.

Devido a grande dinamicidade dos processos sedimentares atuantes 
na área, há um grande está associado aos resultados dos Casos 5 e 6 . A partir dos resultados obtidos nas análises da evolução da linha de costa é possível traçar previsões da posição da linha costa da região de interesse. Na figura 94 se a encontra a linha de costa após 50 anos de atuação das taxas de TVLc sobreposta ao MDT utilizado na determinação das cotas de inundação.

Como pode ser observado na figura 94 , os efeitos processos sedimentares vigentes provavelmente serão muito mais determinantes para fisiografia da linha de costa do que a elevação adicional da NRM. Contudo, a simples extrapolação da posição da linha costa baseada em seu comportamento atual não é suficiente para descartar os efeitos da elevação adicional do NRM na área de estudo.

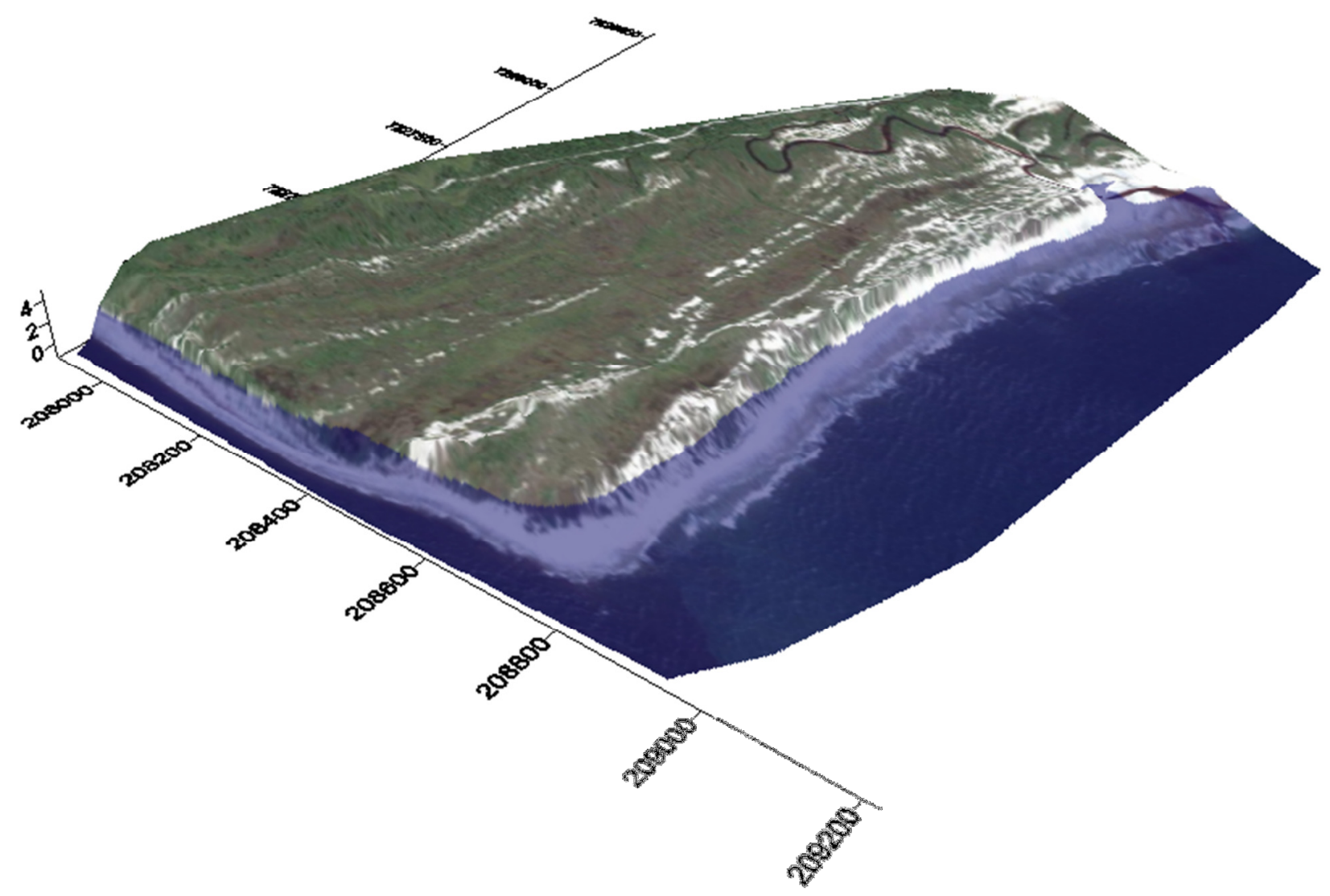

Figura 92: Elevação do mar de 1.27 m sobreposto ao MDT (Caso 5). 


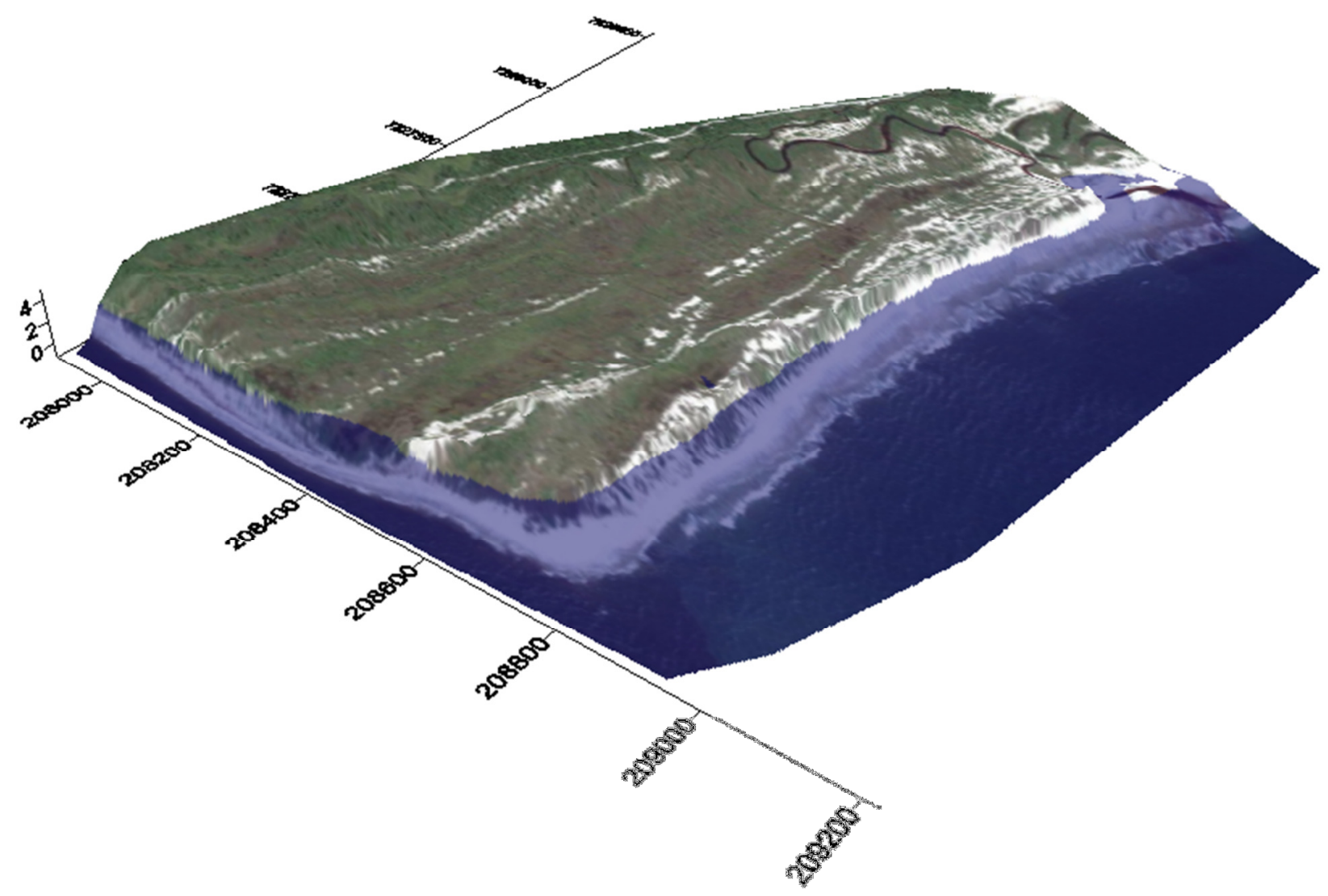

Figura 93: Elevação do mar de $1.52 \mathrm{~m}$ sobreposto ao MDT (Caso 6).

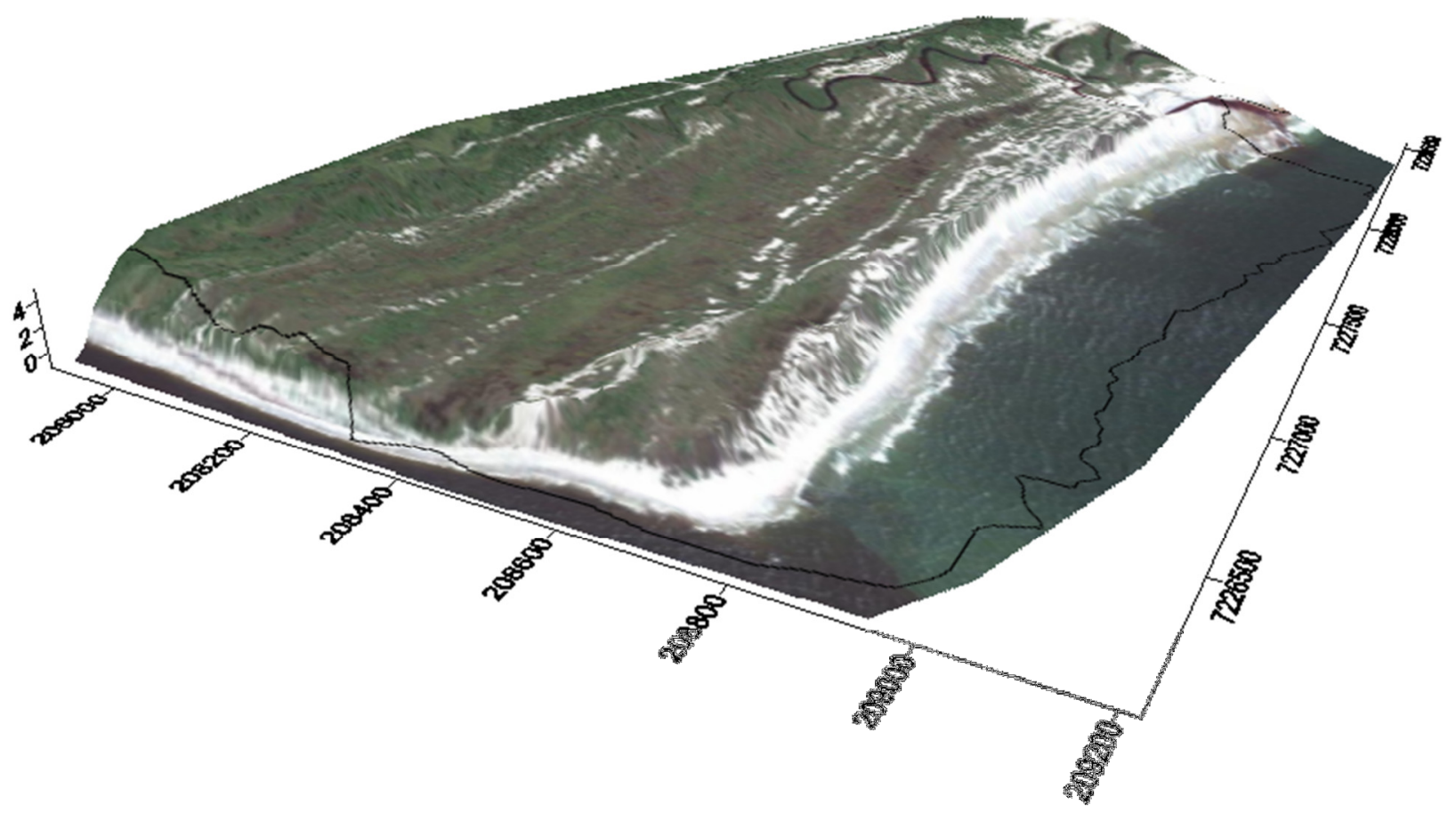

Figura 94: Previsão da posição da linha de costa em 50 anos no futuro baseada nos resultados das análises das linhas de costa. 


\section{Discussão}

A dinâmica sedimentar de ambientes costeiros é composta por uma serie de agentes atuando simultaneamente com intensidades variáveis, produzindo resultados de natureza estocástica a curto prazo. Os padrões e tendências acabam sendo revelados em análises abordando escalas espaciais ou temporais mais amplas (CERC, 2002).

Com o intuito de se entender com mais clareza o papel dos eventos atmosféricos extremos nos processos sedimentares vigentes na região de estudo foram analisados processos atuantes em escalas temporais e espaciais distintas. Nas próximas seções os processos serão analisados separadamente em um primeiro momento, a partir das tendências e padrões encontrados serão realizadas análises integradas para se estabelecer correlações entre forçantes e os processos agindo em escalas distintas.

\section{1 - Escala Diária}

$\mathrm{Na}$ tentativa de se determinar os efeitos da passagem dos sistemas frontais na escala diária foram executados levantamentos topográficos mensais durante o período entre junho de 2011 e fevereiro de 2012. Infelizmente, somente durante a campanha a campo de junho de 2011 apenas um sistema frontal atuou de maneira efetiva na área de interesse.

Os dados referentes a ondas dispostos nas figuras 95, 96 e 97 revelam a atuação de ondas geradas por um ciclone extratropical. Durante a atuação desta frente foi registrado a ocorrência de uma sobrelevação das marés e uma forte atuação dos ventos dos quadrantes S e SE, como pode ser observado nas figuras 98,99 e 100. 


\section{Altura de Ondas entre 03/06/11 e 06/06/11}

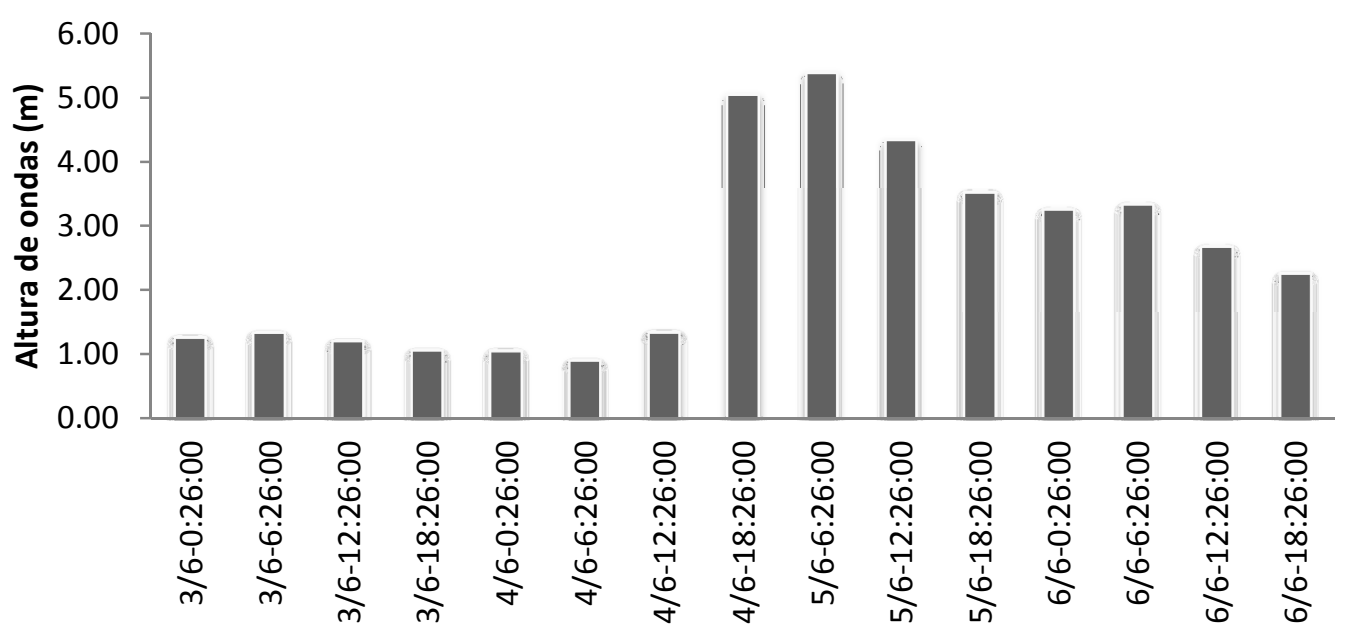

Figura 95: Alturas das ondas registradas entre os dias 03/06/2011 e 06/06/2011, observações com intervalo de $3 \mathrm{~h}$.

\section{Período de Ondas entre 03/06/11 e 06/06/11}

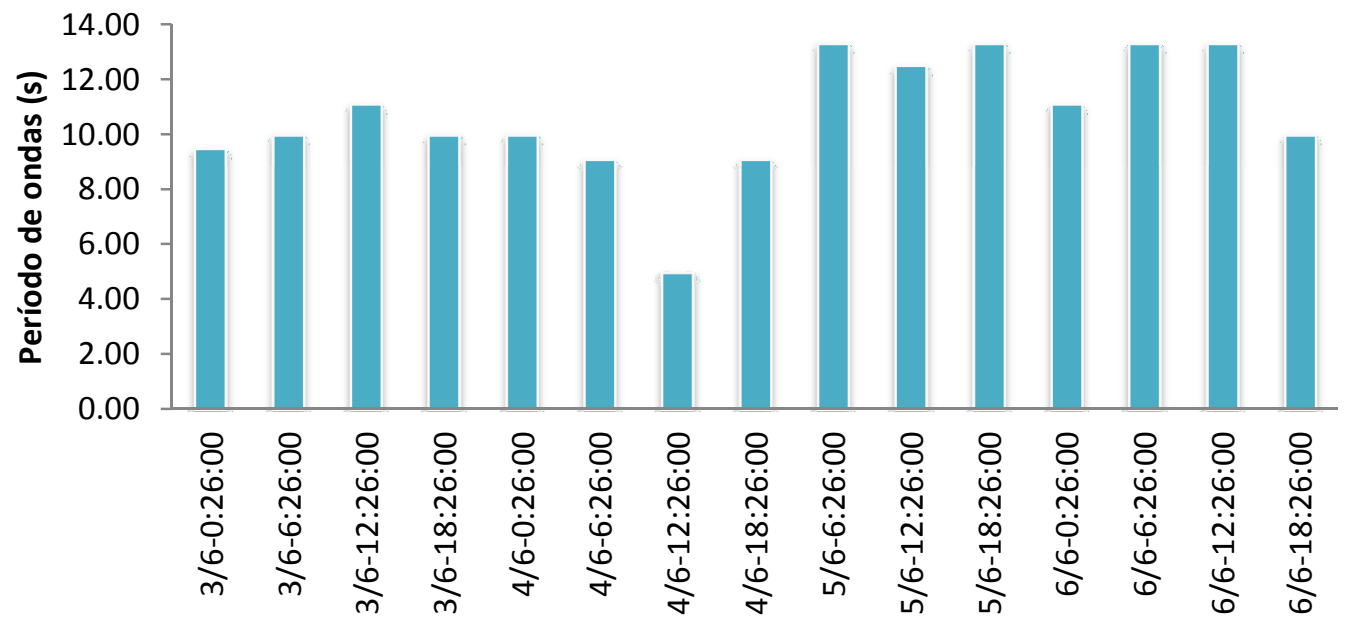

Figura 96: Períodos das ondas registrados entre os dias 03/06/2011 e 06/06/2011, observações com intervalo de $3 \mathrm{~h}$. 


\section{Direção de Ondas entre 03/06/11 e 06/06/11}

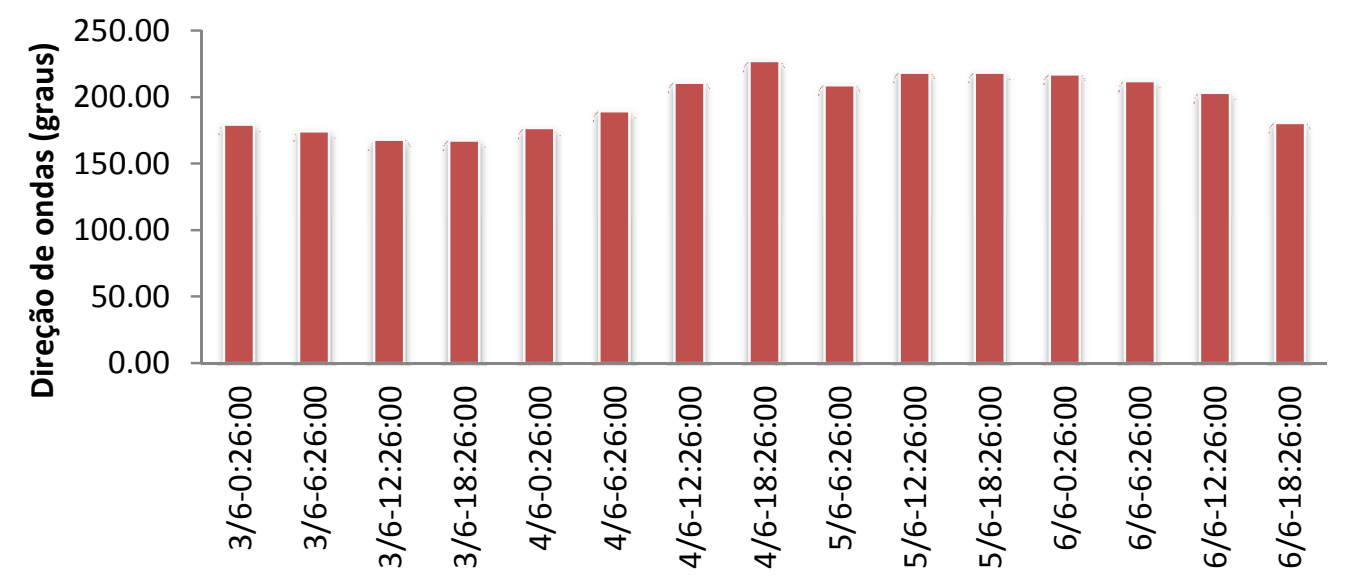

Figura 97: Direções das ondas registradas entre os dias 03/06/2011 e 06/06/2011, observações com intervalo de $3 \mathrm{~h}$.

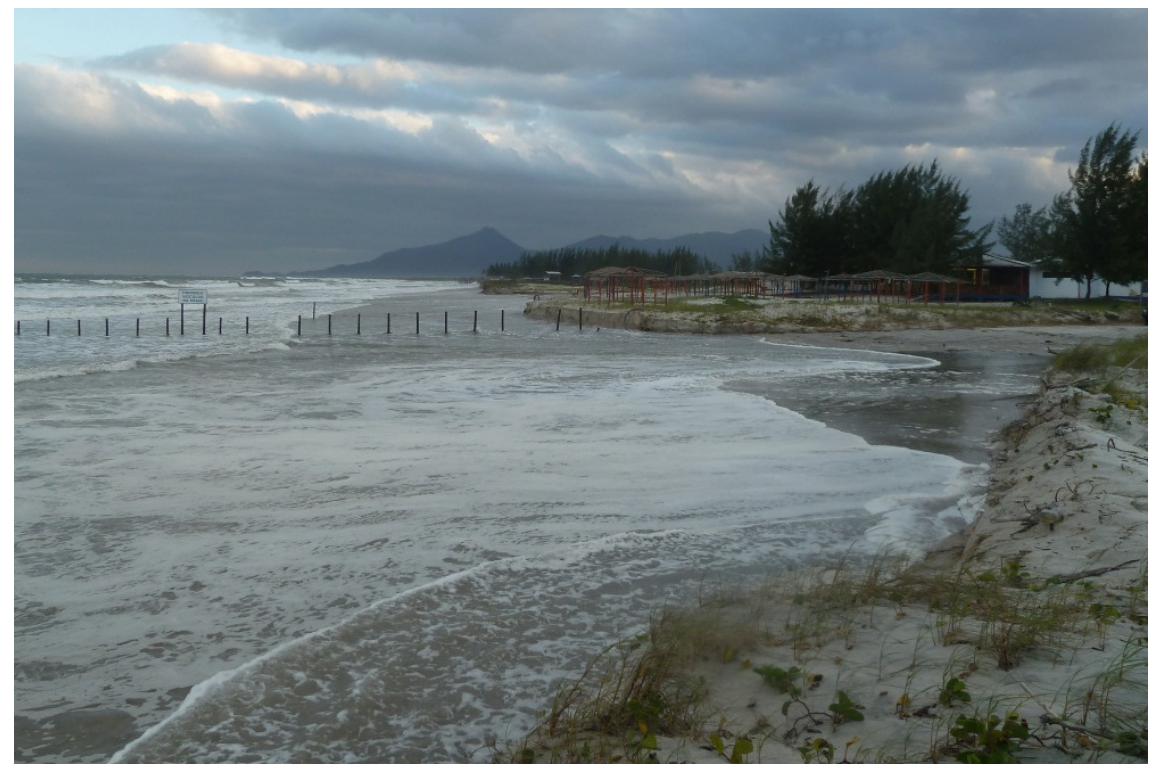

Figura 98: Maré meteorológica observada no dia 04/06, notar a água invadindo a estrada de areia no lado direito da imagem. 


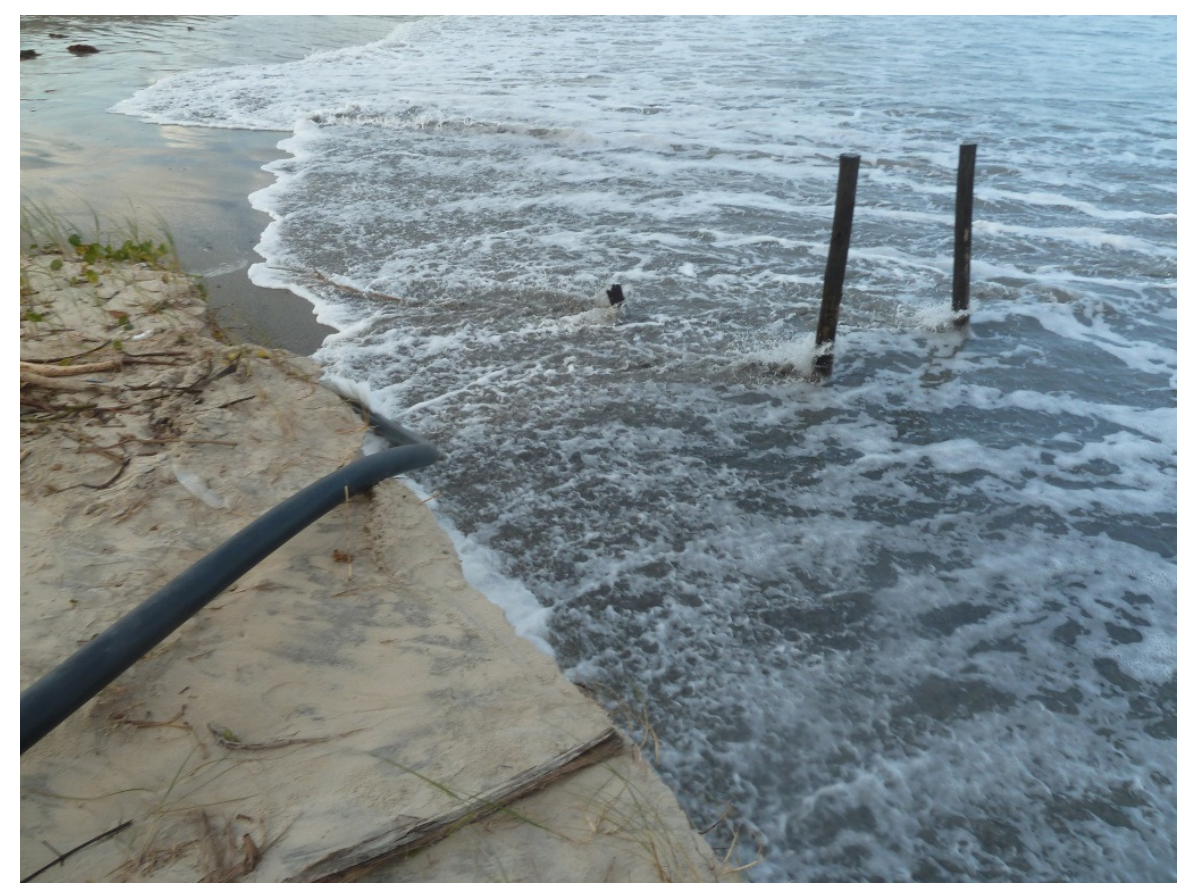

Figura 99: Maré meteorológica observa no dia 04/06, notar a ação das ondas na escarpa que marca o começo da vegetação.

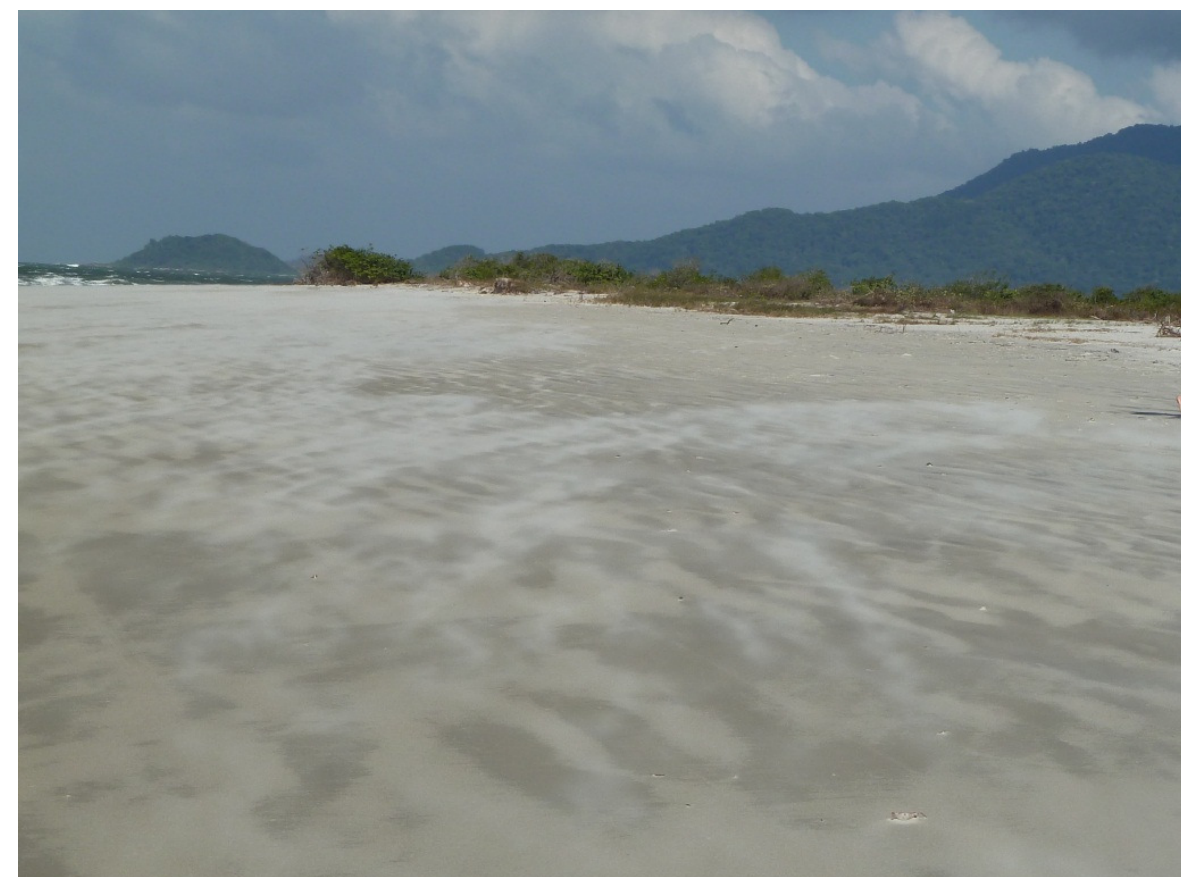

Figura 100: Ação dos ventos transportando sedimentos no dia 04/06, ilhas do Cardoso e do Bom Abrigo ao fundo. 
A partir das comparações entre os MDTs do Setor 2, pode se inferir que os efeitos da passagem da frente fria se traduziram em um transporte de sedimentos do pós-praia em direção as zonas de empinamento e arrebentação, caracterizando o transporte onshore-offshore. As fotos tiradas durante a coleta de dados revelam a presença de uma escarpa erosiva resultante do processo em questão (figuras 101 e 102).

Os dados volumétricos não revelaram grandes alterações no decorrer do evento em nenhum setor estudado, ficando dentro da margem de erro. Apesar de se tratar de um sistema atmosférico particularmente pouco intenso, a incidência de ondas formadas por um ciclone extratropical se provou efetiva na remoção de sedimentos de porções onde este transporte não ocorre normalmente. Para evidenciar o poder das ondas de tempestades, a figura 103 expõe a foto tirada da escarpa produzida pela passagem de uma frente fria no mês anterior, maio de 2011, que segundo relatos dos comerciantes locais causou danos aos quiosques instalados sobre a área já vegetada, onde ocorrem dunas e cordões litorâneos.

Os resultados obtidos estão de acordo com os conceitos de Short (1999), que expõe a predomínio do transporte onshore-offshore em relação ao transporte longitudinal na escala de tempo curto, de horas a poucos dias. $\mathrm{O}$ autor atribui este fato a maior intensidade das correntes envolvidas no transporte onshore-offshore, porém em longo prazo as correntes de deriva litorânea acabam por se mostrarem dominantes na configuração das feições morfológicas. 


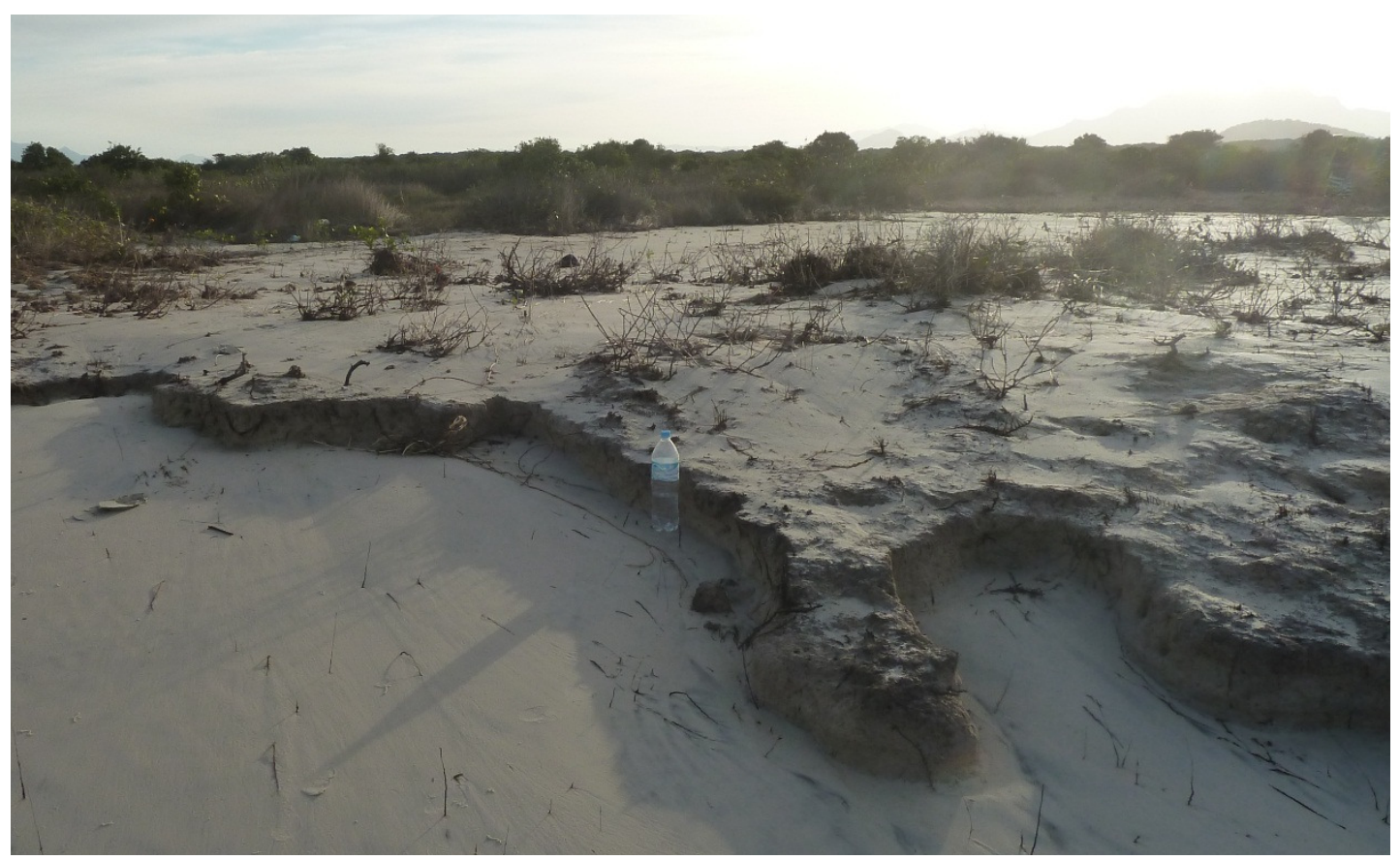

Figura 101: Escarpa observada no dia 06/06/11.

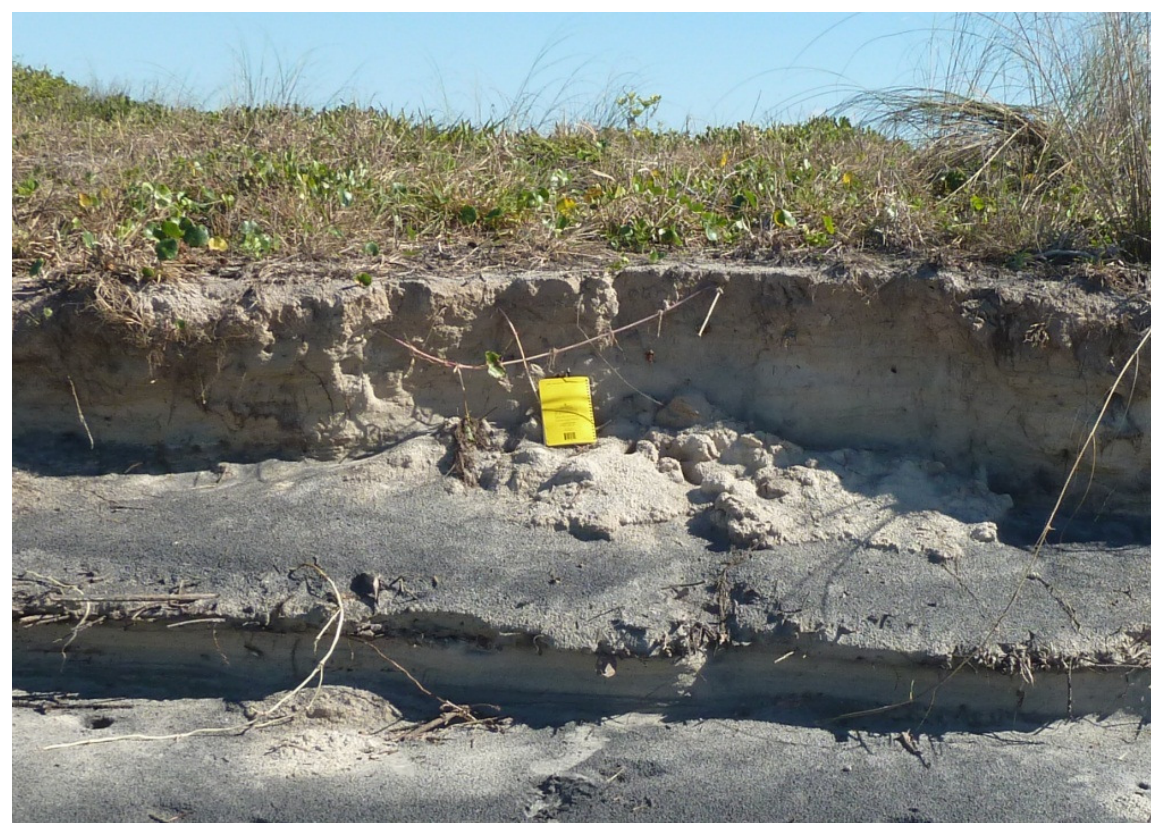

Figura 102: Escarpa secundaria localizada abaixo da escarpa que divide a faixa de areia e vegetação, foto tirada no dia 08/06/11. 


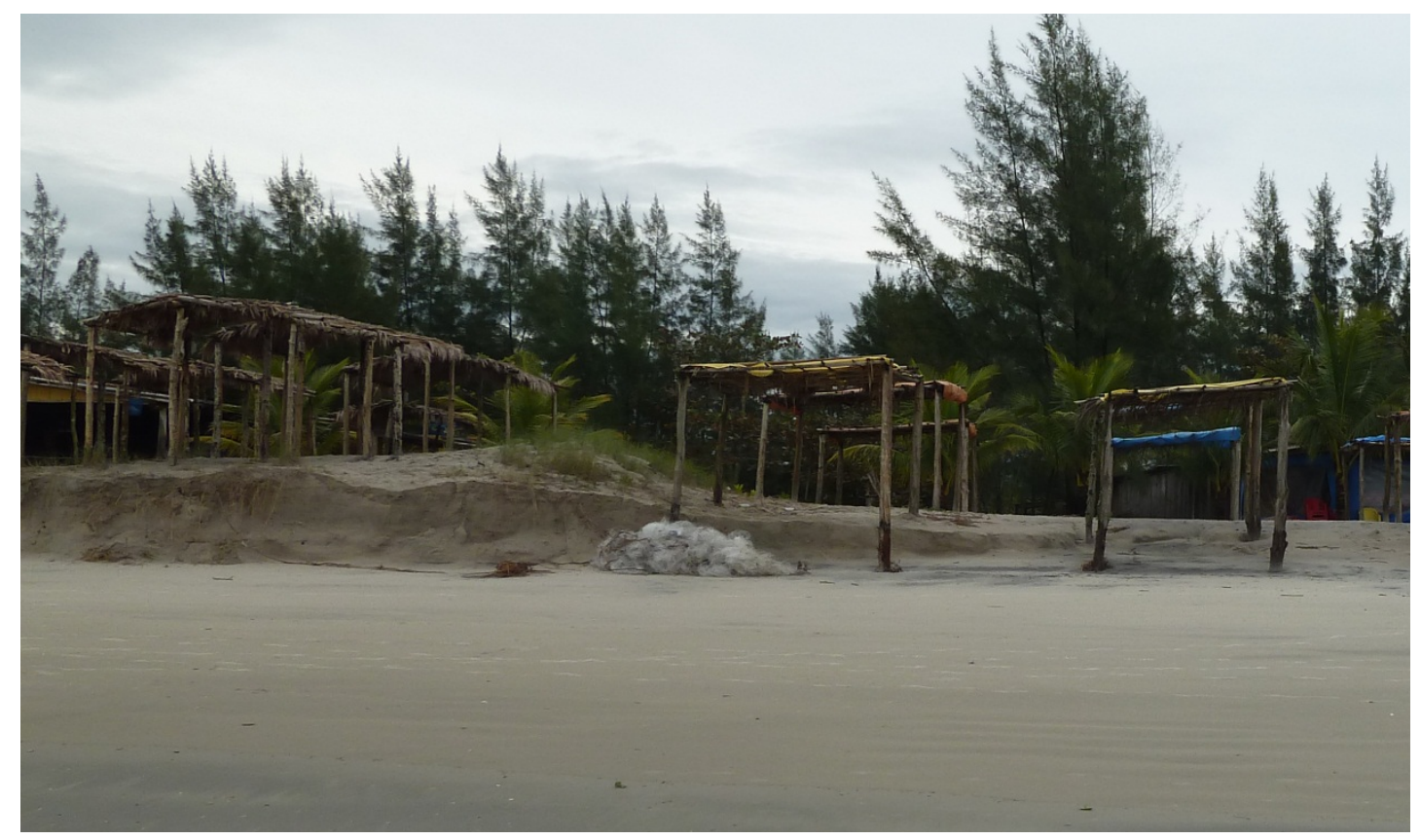

Figura 103: Escarpa produzida pela passagem de uma frente fria no mês de maio de 2011. Segundo os comerciantes locais varias dessas estruturas foram derrubadas.

\section{2 - Escala Mensal}

As análises dos dados topográficos se mostraram mais adequadas para descrever os processos atuantes na escala mensal. A partir dos resultados obtidos foi possível associar os setores definidos a processos sedimentares distintos.

O Setor 1 e a Área Leste do Setor 2 demonstram comportamentos que indicam a dominância dos processos marinhos condicionados pela ação das ondas e correntes decorrentes de sua incidência. Área Sul do Setor 2 parece estar sujeita a um regime misto, dominado pela somatória entre a ação das correntes de maré e a ação das ondas. Os dados acerca das ondulações e precipitações e a análise da variação volumétrica esclarecem melhor esta afirmação. 
Analisando os dados de variação volumétrica nota-se que a maior queda de volume ocorre entre os meses de agosto e setembro de 2011 para o Setor 2 e entre julho e setembro de 2011 para o Setor 1 (figuras 76 a 85). Cabe ressaltar a não execução de campo neste setor no mês de agosto.

As figuras 104, 105 e 106 exibem as alturas, os períodos e as direções das ondas registradas durante o período total das campanhas de campo. Notase os maiores valores de altura de onda entre os meses de julho de 2011 , com registros na casa dos $8 \mathrm{~m}$. Apesar dos volumes apresentarem queda neste período, no entanto a maior diminuição nos valores de volume aconteceu entre agosto e setembro de 2011.

Observado as figuras 80 e 81 observa-se que as direções das ondulações foram semelhantes nas duas ocasiões (cerca de $220^{\circ}$ ), no entanto os períodos das ondulações foram mais intensos entre agosto e setembro. Além desse fato, a análise apresentada pelo CPTEC em sua Síntese Sinótica Mensal para o mês de agosto aponta a ocorrência de marés meteorológicas na costa do Sudeste do país, associadas à passagem de uma frente fria entre os dias 19 e 21 .

Levando-se em consideração a localização da boia de amostragem, pode se apontar a trajetória do ciclone tropical de julho como causa para 0 menor impacto desse sistema na área de estudo. Contudo deve se salientar também que os dados do mês de julho podem estar comprometidos devido a falhas do equipamento de aquisição do programa PNBOIA. 


\section{Altura de Ondas Durante o Período Total de}

Amostragem

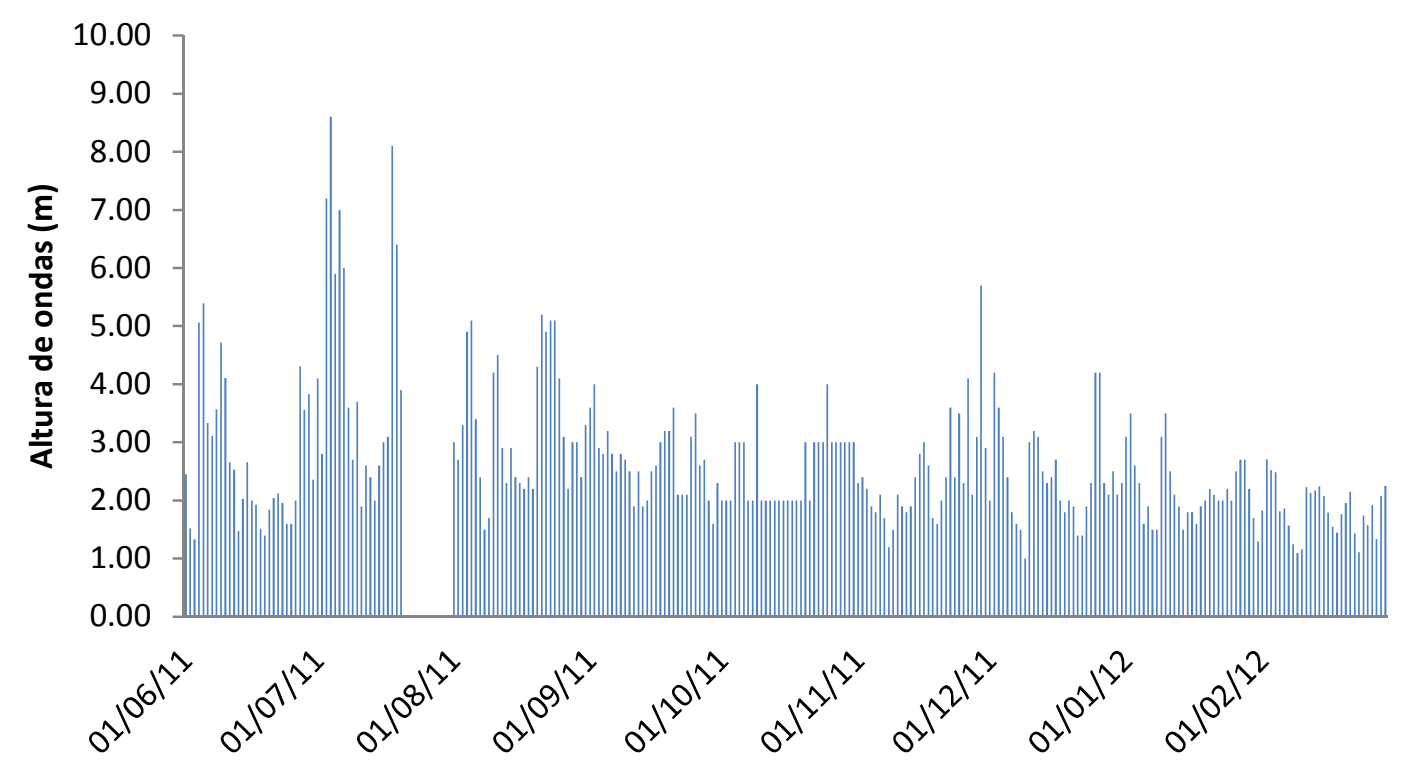

Figura 104: Altura das ondulações registradas durante o período entre 06/2011 e 02/2012.

Direção de Ondas Durante o Período Total de

\section{Amostragem}

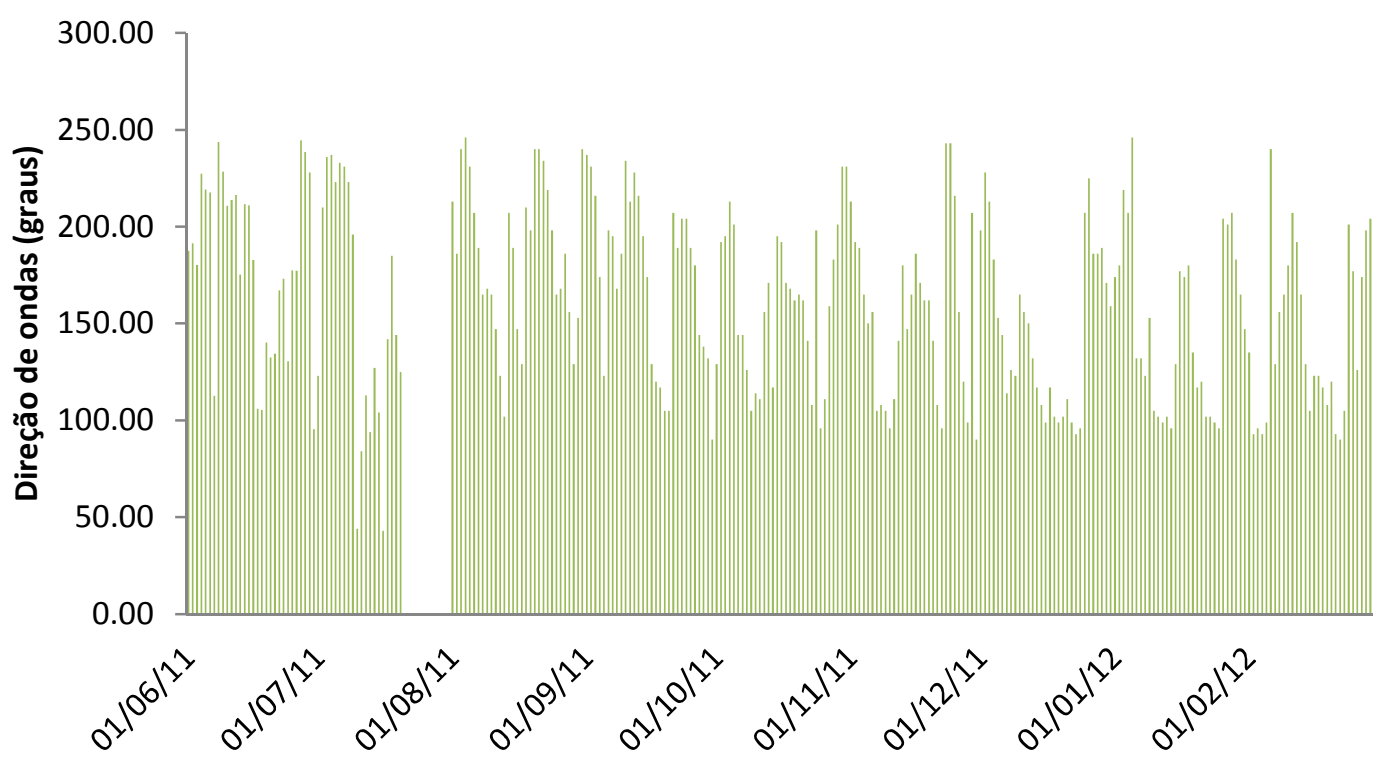

Figura 105: Direções das ondulações registradas durante o período entre 06/2011 e 02/2012. 


\section{Período de Ondas Durante o Período Total de Amostragem}

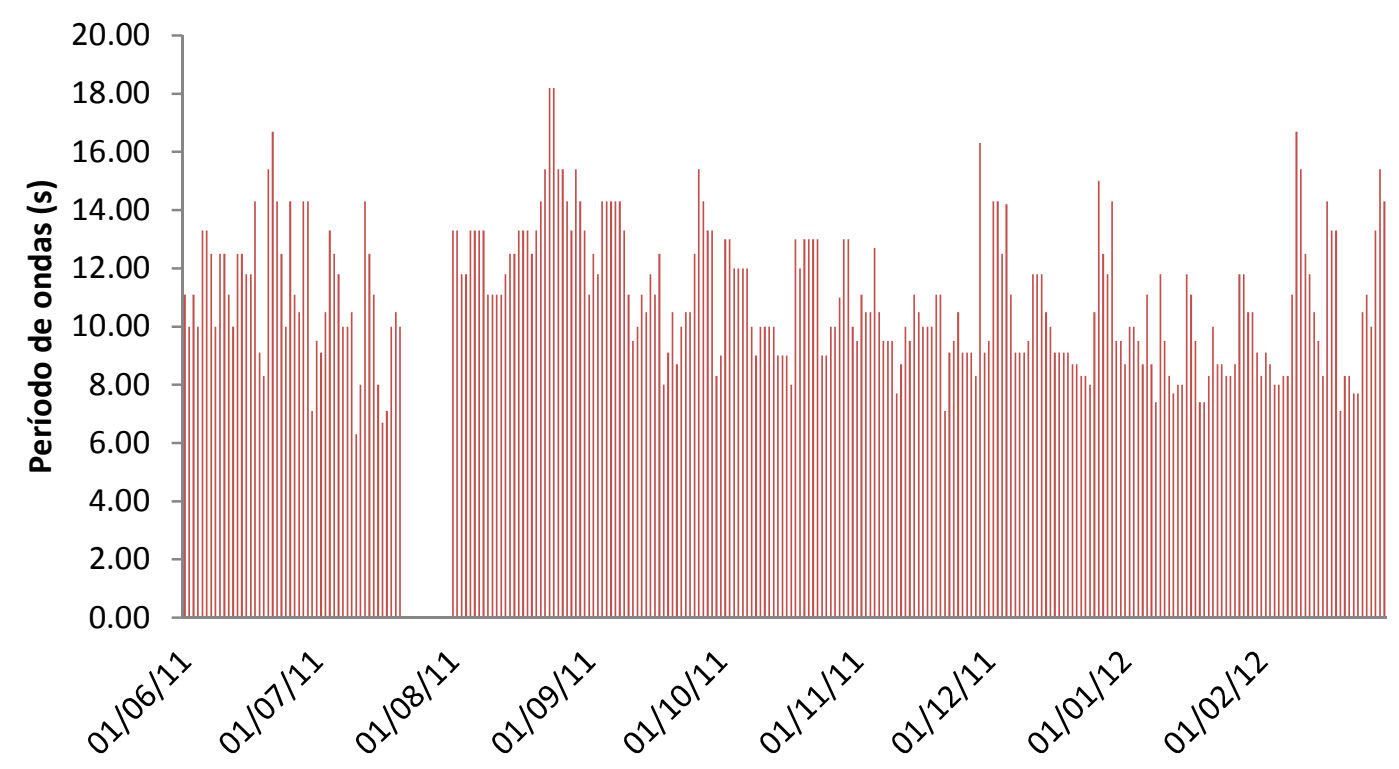

Figura 106: Períodos das ondulações registradas durante o período entre 06/2011 e 02/2012.

Embora haja está discrepância entre a variação de volume e a incidência de ondas, a tendência de acresção encontrada no Setor 1 e na Área Leste pode ser justificada pela diminuição da altura das ondas ao longo do período de estudo, como observado na figura 104. Tal situação é ocasionada pela mudança das condições meteorológicas, as quais, durante o inverno e o outono favorecem a incidência dos sistemas atmosféricos responsáveis pela formação de ondas energéticas. Durante o verão, as condições atmosféricas favorecem o enfraquecimento da influência desses sistemas na costa sul e sudeste do Brasil.

A luz dessas informações pode-se afirmar que tanto a Área Leste, quanto o Setor 1 demonstraram o comportamento clássico de sistemas praias caracterizado nos trabalhos expostos na revisão bibliográfica (Sonu \& Van Beek, 1971; Komar 1976; Hallermeir, 1981 entre outros), apresentando uma 
tendência de gradual acresção, reflexo da diminuição da energia das ondas incidentes (condições de tempestade e de tempo bom).

Apesar das medições necessárias para a aplicação da escala geomorfológica de Wright \& Short (1984) não terem sido realizadas, com base em suas características pode se qualitativamente classificar toda a extensão do Setor 1 e da Área Leste como dissipativas, conclusão também presente no trabalho de Nascimento Jr (2006). A única exceção é a porção localizada mais a sul da Área Leste, a qual apresenta características intermediárias, como a presença de bancos de areia longitudinais próximos a zona de arrebentação, separados da face praial por uma calha pronunciada.

Esta situação está provavelmente associada a formação de bancos de areia através da interação entre os trens de onda incidentes e as correntes de maré provindas da Desembocadura de Cananéia. Durante as campanhas a campo dos meses de janeiro e fevereiro de 2012 foi possível observar a junção desses bancos com o prisma praial, resultando em poças d'água na face praial e na zona de arrebentação durante as marés baixas (figura 107).

Este fenômeno é observado constantemente no local, sendo uma atração turística conhecida como "piscinas naturais". Seu processo formador provavelmente está ligado ao balanço entre a atuação das ondas e das marés. Tendo se em vista que as feições foram observadas durante os meses do verão, período caracterizado pelo enfraquecimento dos eventos atmosféricos intensos e predomínio das ondas de $E$, as situações de ausência da incidência de ondas energéticas que transportam os sedimentos dos bancos em direção ao mar aberto devem favorecer a formação dessas poças de maré.

A foto área de 2001, apresentada na figura 108, demonstra a presença 
de uma grande acumulação de água no setor em questão. Sua ocorrência deve estar ligada diminuição da intensidade e/ou da ocorrência de sistemas atmosféricos intensos por um período prolongado, na escala temporal de anos a décadas.

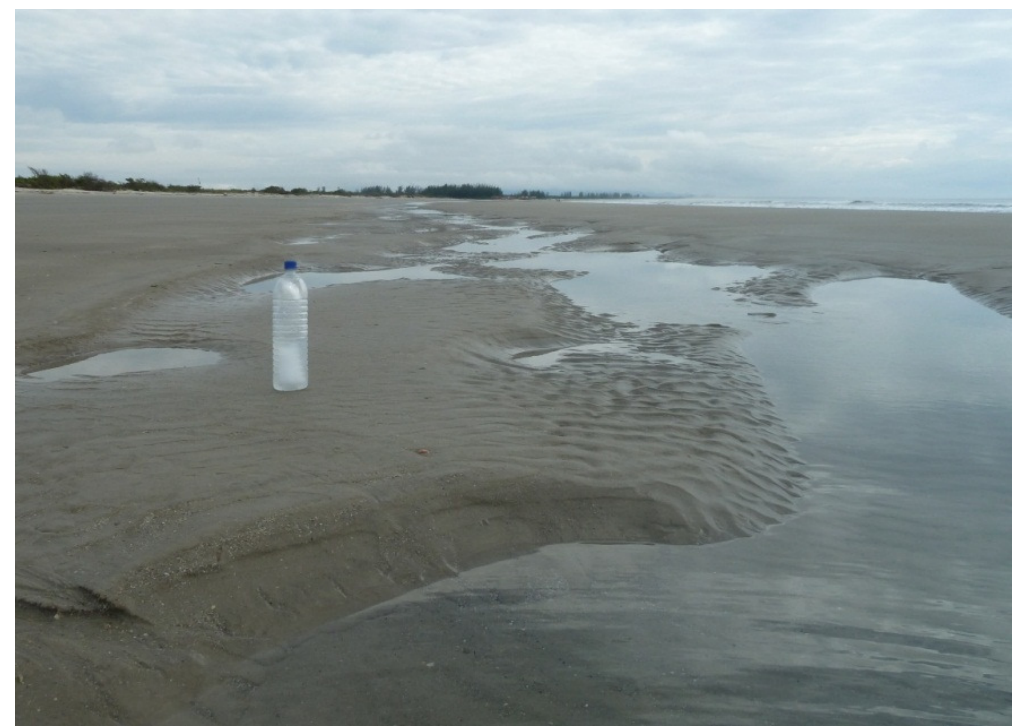

Figura 107: Poças de água acumuladas na face praial e zona de arrebentação no mês de fevereiro de 2012.

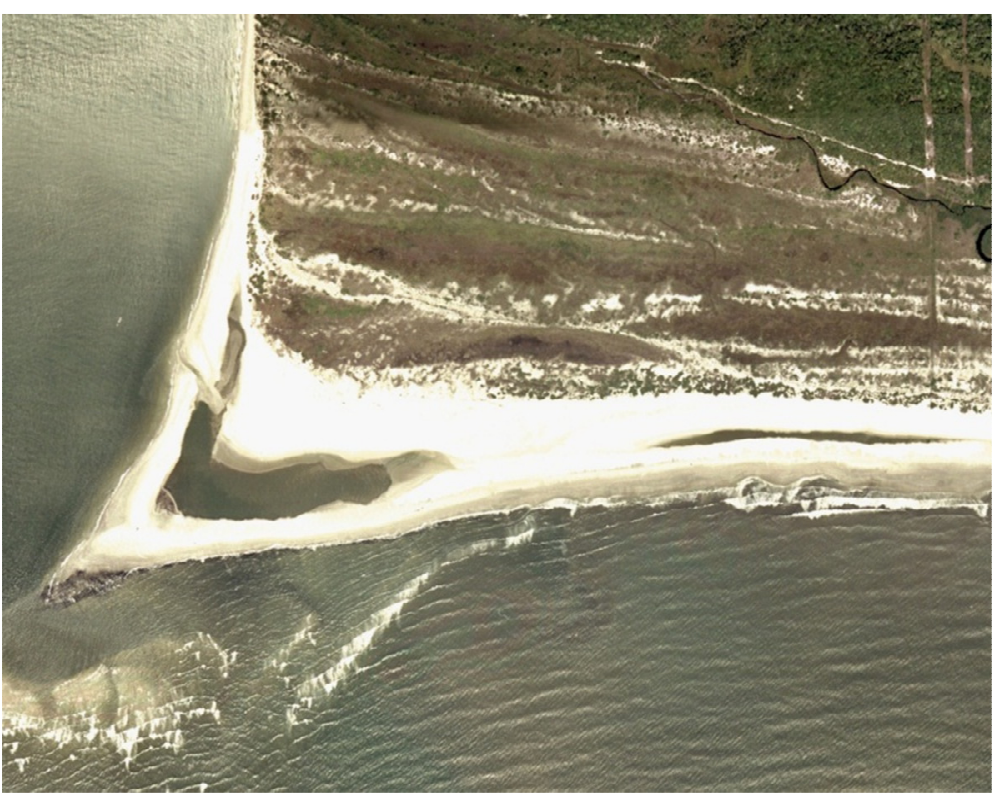

Figura 108: Acumulações pronunciadas de água na faixa de areia no ano de 2001. 
Como esperado a Área Sul apresentou uma dinâmica mais marcada pela influência das correntes de maré atuantes na Desembocadura de Cananéia, porém o fato da maior queda nos volumes ter ocorrido simultaneamente em todos os setores estudados demonstra o forte impacto da ação das ondas de tempestade nesta área.

Em relação às comparações entre os MDTs, a Área Sul apresentou os maiores valores de perda sedimentar, contando com a ocorrência de uma área com concentração de erosão, como pode ser observado na figura A49 do Anexo I. Os valores totais de perda chegam a faixa de $-1,6 \mathrm{~m}$, acarretando inclusive na migração do limite entre a faixa de areia a zona vegetada, como demonstrado na figura 109. Nas proximidades desta zona, encontra-se uma área com valores elevados de ganho sedimentar. Está instabilidade pode ser atribuída a proximidade da curva fisiográfica do Pontal de Fora, configurando uma zona de transição entre os domínios de processos relacionados à ação das ondas e das correntes de maré.

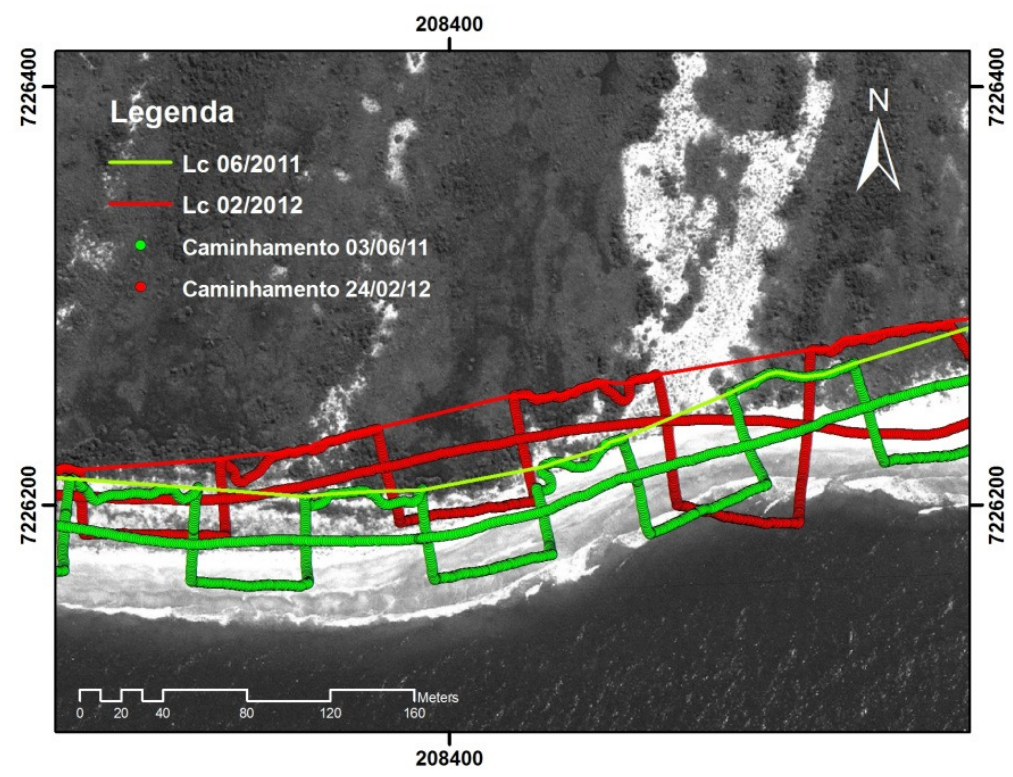

Figura 109: Comparação entre os caminhamentos dos dias 03/06/2011 e 24/02/2012 denotando a retração da linha de vegetação. Imagem de satélite de 2009 ao fundo. 
Foram observadas duas situações diferentes quanto aos dados de volume da Área Sul. Tratando-se dos volumes totais, após o evento erosivo entre agosto e setembro de 2011 nota se um aumento do volume, com uma diferença total negativa na faixa de $2000 \mathrm{~m}^{3}$. Nas análises referentes aos volumes líquidos a maior perda também ocorre entre agosto e setembro, contudo, pode se observar uma diminuição continua desde o primeiro campo, totalizando cerca de $9000 \mathrm{~m}^{3}$ negativos de diferença total.

Tais padrões indicam o progressivo transporte de sedimentos do póspraia em direção ao canal, evidenciando a continua atuação das correntes de maré como agente transportador, visto que a intensidade das ondas diminuiu com a chegada das estações mais quentes. Todavia, o fato do aumento do volume total após o evento erosivo mais marcante indica a ação das ondas como agente que de fato transporta os sedimentos para fora da área amostrada. O aumento da precipitação durante os meses de janeiro e fevereiro de 2012 parece não ter afetado significativamente o volume de sedimentos transportados na Área Sul.

\section{3 - Escala Decadal}

Os resultados obtidos com relação à evolução da linha de costa foram produzidos a fim de se caracterizar a dinâmica sedimentar da Desembocadura de Cananéia atuante na escala decadal e compara-los com os trabalhos já realizados.

As tendências encontradas estão de acordo com os resultados de trabalhos pretéritos, como Besnard (1950), Sadowsky (1953,1954), Petri \& Suguio (1971), Suguio \& Tessler (1983), Tessler et al. (1990) e Conti et al. 
(2012), considerando que estes trabalhos analisaram a variação da face praial e não da linha que separa a vegetação da faixa de areia. Por outro lado, os resultados pretéritos demonstram que os processos vigentes na atual área de estudo de estudo tem forte relação com os processos atuantes na porção norte da llha do Cardoso, tanto na margem do canal, quanto na sua face oceânica.

Apesar dos erros associados a qualidade das imagens utilizadas e ao processo de georreferenciamento, os resultados quantitativos encontrados são semelhantes aos obtidos por Conti et al. (2012) em sua comparação das linhas de costa obtidas através de fotos aéreas e imagens de satélite. Os autores relatam uma acresção de cerca de $120 \mathrm{~m}$ nas adjacências da ponta da trincheira entre 1962 e 1981 e mudanças da ordem 500 m, entre ganhos e perdas, na linha de costa na área da ponta oposta de llha Comprida. $O$ presente estudo obteve valores de ganho de linha de costa entre 120 e 130 para o Setor 1 (Ponta da Trincheira) entre os anos de 1962 e 1981, e valores máximos na ordem dos 250 m de acresção para a porção do Setor 3 localizada nas proximidades da ponta leste de llha Comprida.

Os três setores definidos refletem a alternância de domínio das diferentes forçantes físicas presentes na área, que são em termos gerais as correntes de maré e a descarga fluvial, a ação das ondas e o vento. O Setor 1 é o mais abrigado da incidência de ondas, sendo mais influenciado pelas correntes de maré e pelo vento. Sadowsky (1954a) descreve a ocorrência de erosão na Ponta da Trincheira, além relatar a tendência erosiva da região desde os tempos da colonização portuguesa. Porém, os resultados do atual trabalho e dos trabalhos de Tessler et al.(1990) e Conti et al.(2012) revelam pelo menos um período de acresção durante os anos de 1962 e 1981, seguido 
da retomada da tendência erosiva entre 1981 e 2009.

Sadowsky (1954a) e Tessler et al.(1990) atribuem a tendência erosiva ao embate das ondas, apoiados no recuo para $\mathrm{W}$ da Ponta do Perigo na llha Cardoso, expondo cada vez mais a Ponta da Trincheira a ação das ondas. Os resultados de Conti et al. (2012) demonstram uma tendência de avanço em direção a $\mathrm{E}$ da Ponta do Perigo nos últimos anos, voltando a proteger a Ponta da Trincheira, a qual por sua vez não apresentou redução em sua tendência erosiva. Outro fator a se levar em consideração para explicar a causa da alternância entre os ciclos de erosão e acresção do Setor 1 é a intensificação das correntes de maré vazante exercida pelo canal do Valo Grande em Iguape (Bergamo, 2000) que, como já mencionado, foi aberto em 1841, fechado em 1978 e tornou a ser aberto em 1995. As datas de fechamento e abertura do canal são próximas às mudanças no padrão de sedimentação identificadas, no entanto considerando os vários possíveis agentes transportadores atuantes na área e a grande distância que se encontra o canal do Valo Grande, sua influência deve ser relativizada, assim como possíveis oscilações nas marés, regime de precipitação e ocorrências de ciclones extratropicais durante 0 período em questão.

O Setor 2 se encontra na área afetada tanto pela ação das marés quanto pela incidência de ondas, principalmente durante eventos atmosféricos extremos. A tendência erosiva identificada vem sendo reportada desde 1950, com evidências da "migração" do canal da desembocadura de Cananéia na direção NE (Besnard, 1950; Sadowsky, 1954a), como foi apontado em todos os trabalhos subsequentes já mencionados. A razão desta constância erosiva parece ser a atuação das corretes de maré, tanto no ciclo enchente, quanto 
vazante. Os resultados obtidos por Conti et al.(2012) mediante a aplicação de dois modelos de transporte de sedimentos baseados nas características sedimentares e morfológicas, e um modelo numérico hidrodinâmico reforçam o papel erosivo das marés, principalmente do ciclo vazante.

Apesar da aparente predominância das correntes de maré, a influência das ondas não pode ser menosprezada, mesmo apresentando menor frequência de atuação (Sadowsky, 1954a, Suguio \& Tessler, 1983, Tessler et al., 1990). Devido a proteção natural da llha do Bom Abrigo e dos bancos de areia presentes na saída da Desembocadura, somente as ondas dos quadrantes S, SW e E conseguem atuar na margem do canal, em especial as ondas de S e SW. Estas ondas estão relacionadas aos ciclones extratropicais, que podem causar marés meteorológicas e, por conseguinte, aumentar a energia com que as elas chegam à linha de costa.

O fenômeno das marés meteorológicas foi levantando no trabalho Conti et al. (2012), sendo que a simulação numérica realizada sobre a hidrodinâmica atuante na Desembocadura de Cananéia e entornos revelou que as correntes de maré perdem muito sua competência durante tais episódios. $\mathrm{O}$ papel de tais eventos com certeza agrava a tendência erosiva causada pelas correntes de maré.

O Setor 3 é a porção mais afetada pela ação das ondas de gravidade, sendo preponderantemente regido pela dinâmica marinha, com a influência das correntes de maré localizada nas adjacências do Pontal de Fora. A forte tendência progradante da área foi também identificada nos trabalhos de Tessler et al. (1990), Guedes (2009) e Conti et al. (2012). Tessler et al. (1990) associa esse processo a incidência de ondas de SW, S e SE e a consequente 
corrente de deriva litorânea com rumo NE. O processo de migração dos sedimentos representaria a tendência geral do litoral sul paulista de predominância da deriva com sentido NE (Tessler, 1988). O sedimento transportado para o Setor 3 teria contribuições das margens do canal da desembocadura e do sedimento vindo da face oceânica da llha do Cardoso, como observado nos resultados de Tessler et. al (1990) e Conti et al. (2012), e, possivelmente, do litoral paranaense.

A predominância do sentido de deriva litorânea para NE não significa a inexistência de correntes longitudinais para S e SE, associadas a ondas de E e NE. De fato, a maior parte do tempo esta é a deriva litorânea dominante, porém sua intensidade parece não ser suficiente para vencer o molhe hidráulico criado pela desembocadura de Cananéia. Tais correntes parecem estar ligadas aos bancos móveis presentes de forma paralela a interface da desembocadura com o mar, conhecidos por dificultar a passagem de embarcações (Besnard, 1950; Sadowsky, 1954a; Tessler et al., 1990)

Deve-se fazer uma ressalva aos resultados obtidos na área mais ao norte do Setor 3, pois além da presença do já mencionado rio (figura 57), nas áreas um pouco mais norte existe a presença de ocupação humana, que deve exercer influências sobre a dinâmica sedimentar nesta porção. Exemplo de tal situação foi o desvio do curso rio com o intuito de proteger os quiosques da praia durante o período de monitoramento de campo, no mês de junho de 2011.

\section{4 - Análises Integradas}

Os resultados alcançados permitem a formulação de um panorama 
geral da dinâmica sedimentar da área de estudo. Os parágrafos seguintes detalham as interações e integração dos processos identificados nas análises realizadas.

A presença da Desembocadura de Cananéia e da llha do Bom Abrigo faz com que este setor da costa atue como uma armadilha de sedimentos que se expressa na forma dos bancos dispostos em seu entorno. Tais bancos podem ser interpretados como deltas de maré vazante. A configuração menos pronunciada dos bancos de maré enchente pode ser entendida como uma situação de domínio das correntes de maré vazante no sistema, como elencado por Miyao (1977) e Bergamo (2000). A compreensão do processo de formação e evolução dessas acumulações sedimentares parece ser a chave para se entender melhor o papel das frentes frias no sistema costeiro formado pela desembocadura e as praias circundantes.

Analisando a saída da desembocadura sobre a ótica do modelo desenvolvido por Oertel (1988), pode-se situar a Desembocadura de Cananéia entre os itens c e d da figura 10 (como pode ser observado na figura 110), caracterizando uma alternância entre o domínio das correntes de maré e da deriva litorânea com sentido S. Entretanto, tal situação é ocasionada pelo fato do alinhamento do canal principal da desembocadura apresentar o rumo NW/SE e, por consequência, de uma curvatura do embasamento cristalino.

Como já mencionado a causa de tal alinhamento ainda não está muito clara, podendo ser o canal um leito de rio afogado pela subida do nível do mar (Suguio \& Tessler, 1983), ou estar relacionada a processos tectônicos (GEOBRÁS, 1966; Souza et al., 1996), qualquer que seja sua origem este alinhamento mascara o domínio da deriva com rumo NE, amplamente aceito na 
literatura e de acordo com o padrão de incidência de ondas encontrado.

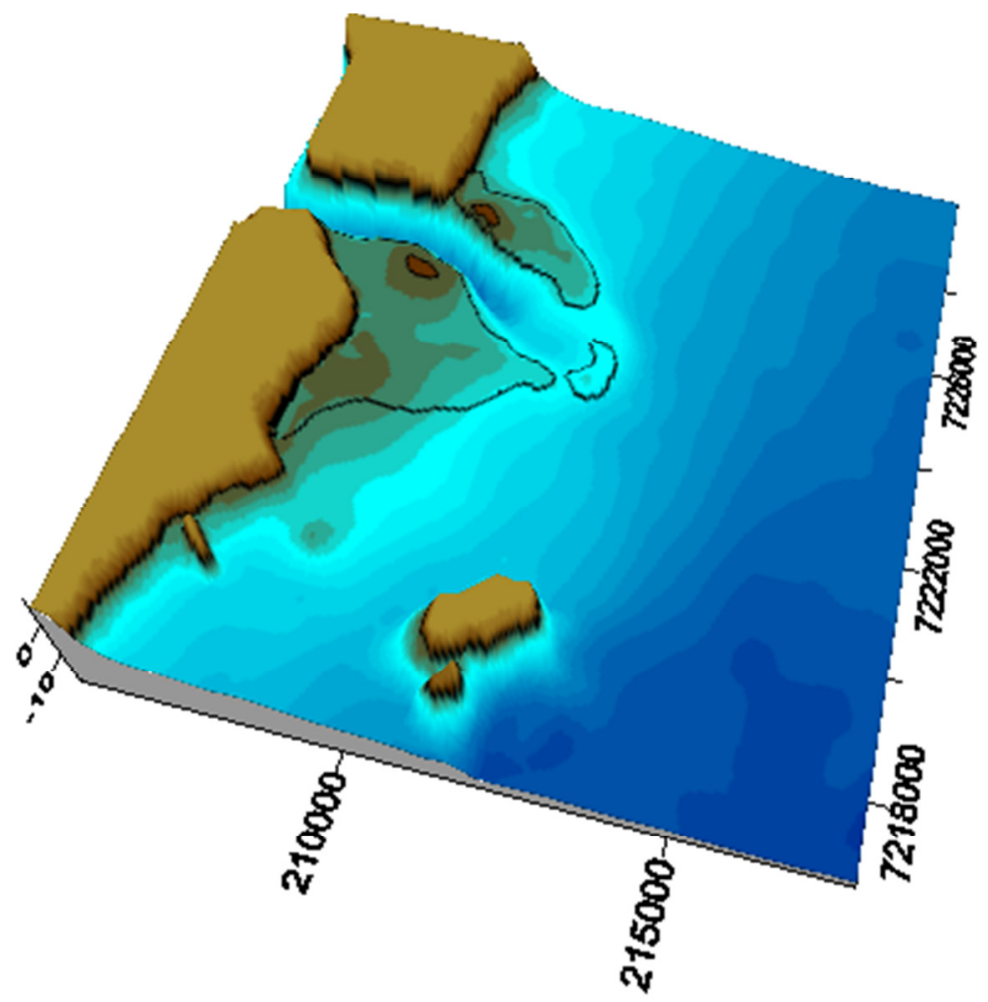

Figura 110: Posição dos deltas de vazante saída da Desembocadura de Cananéia.

Os bancos de areia localizados ao largo da llha do Cardoso estão associados ao efeito de sombra causado pela presença da llha do Bom Abrigo, especialmente em relação às ondas provindas de ESE, SE e SSE como demonstrado pelas simulações numéricas realizadas. Este fato somado a ação das correntes de maré da desembocadura propícia às condições necessárias para formação dessas feições (Tessler et al., 1990). Os resultados expostos em Conti et al.(2012) demonstram a tendência crescimento de rumo NE da linha de costa desta zona da llha Cardoso. O processo responsável por esta situação seria a ação conjunta das ondulações provenientes de $\mathrm{E}$ e NE, que agregam os bancos de areia a linha de costa por meio do transporte onshoreoffshore, e das ondulações provindas de $S$ e SW, que transportam os 
sedimentos para NE por meio da deriva litorânea. A saída da desembocadura limita esse processo de crescimento da linha de costa por meio do molhe hidráulico criado pelas correntes de maré.

Na margem do canal de llha Comprida, os resultados obtidos a partir da confecção dos MDTs para a Área Sul do Setor 2 demonstram a ação conjunta das correntes de maré e ondas no processo erosivo que vem atuando nesta região desde 1962. Os resultados das variações volumétricas indicam que a ação das correntes de maré transportam os sedimentos dos setores mais elevados da faixa de areia em direção ao canal. As mesmas análises também revelam que o agente que de fato retirou o sedimento da Área Sul foi à atuação das ondas de tempestade, principalmente as provenientes dos quadrantes $\mathrm{S}$ e SW.

A partir dessa tendência pode-se inferir que a atuação das correntes de maré e das ondas de tempo bom (provinda dos quadrantes $\mathrm{E}$ e NE) propiciam a formação e agregação dos deltas de maré vazante a faixa de areia, como observado durante os meses de verão no período das coletas. A ação das ondas geradas pela passagem de frentes frias estaria ligada ao transporte do sedimento para NE, erodindo os bancos areia do delta de maré vazante, bem como disponibilizando os sedimentos do pós-praia da margem do canal e da porção oceânica para transporte.

A figura 111 compara as linhas de costa de 2001, 2009 e a linha de costa obtida através dos dados do levantamento de 26/02/2012. Pode-se observar na figura a indicação de um processo crescente de erosão nas adjacências da curva fisiográfica da Desembocadura. O processo parece ter se iniciado entre 2001 e 2009 na região da curva com orientação E/W em relação 
ao mar, e ter se expandido tanto a $\mathrm{W}$ quanto a $\mathrm{NE}$, atingindo também face praial de Ilha Comprida com orientação SW/NE.

A figura 112 ilustra a sobreposição das linhas de costa de 2001 e 2009 ao MDT criado a partir da comparação entre os MDTs de junho de 2011 e fevereiro de 2012. Pode se observar que a zona onde ocorreu a maiores perdas altimétricas está localizada nas proximidades da área que sofreu recuo da linha de costa entre 2001 e 2009, reforçando a tendência de migração da erosão rumo as áreas mais interiores do canal.

Os resultados da determinação das contas de inundação apontam a Área Sul como a sujeita aos maiores riscos de inundação justamente devido concentração de perda sedimentar na área ilustrada na figura 112, reforçando a vulnerabilidade desta área a ação dos trens de ondas.

Apesar da diferença de escala de tempo envolvida nos transporte onshore-offshore e deriva litorânea, a situação de migração e intensificação do processo erosivo pode ser interpretada como uma possível preponderância da ação das ondas sobre a atuação das correntes de maré neste trecho da Desembocadura de Cananéia a partir de 2001. Contudo, não se pode deixar de frisar que a escala de tempo dos levantamentos de campo provavelmente corresponde a variações sazonais do sistema praial ligadas à circulação atmosférica, sendo necessária a aquisição de dados por períodos mais longos para uma comparação mais efetiva com os padrões decadais de variação da linha de costa. 


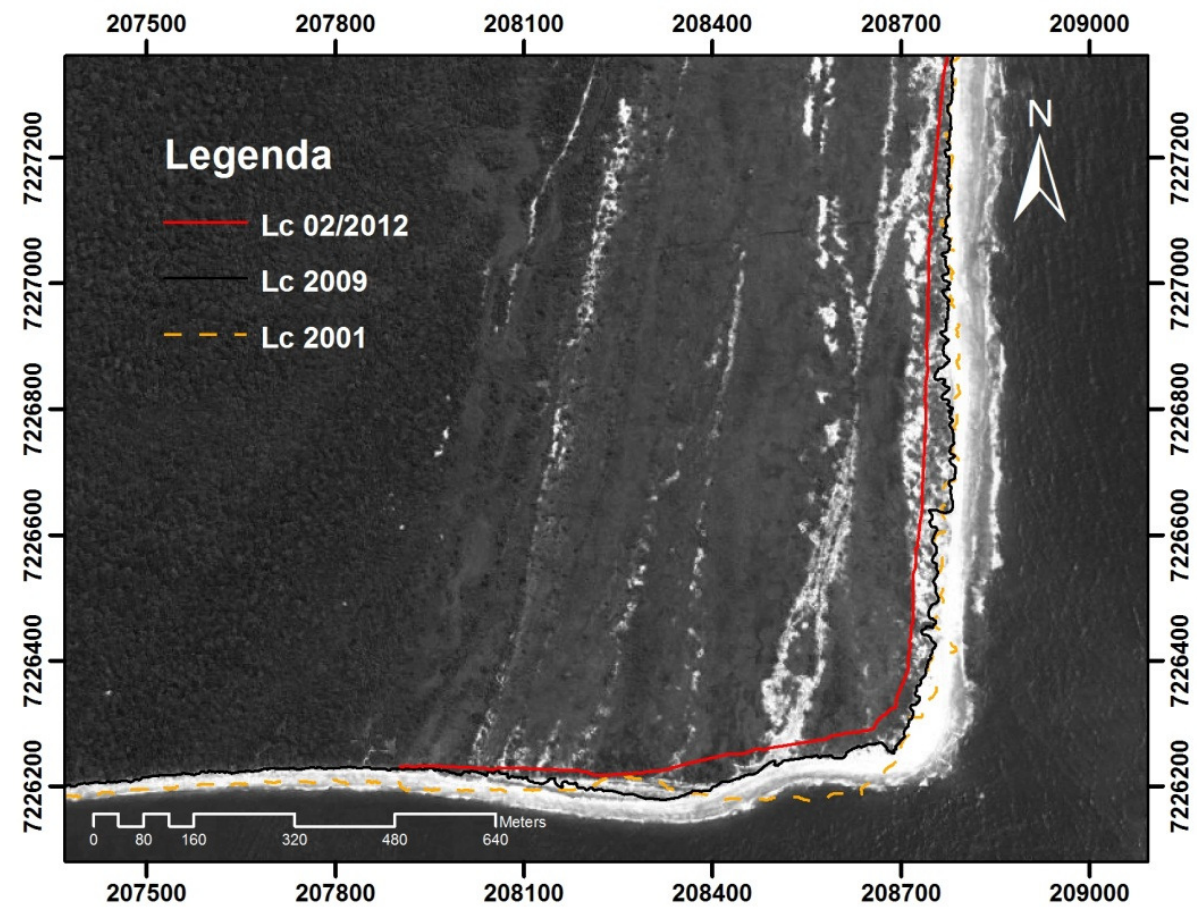

Figura 111: Comparação entre as Linhas de Costa de 2001, 2009 e fevereiro de 2012. Imagem de satélite de 2009 ao fundo.

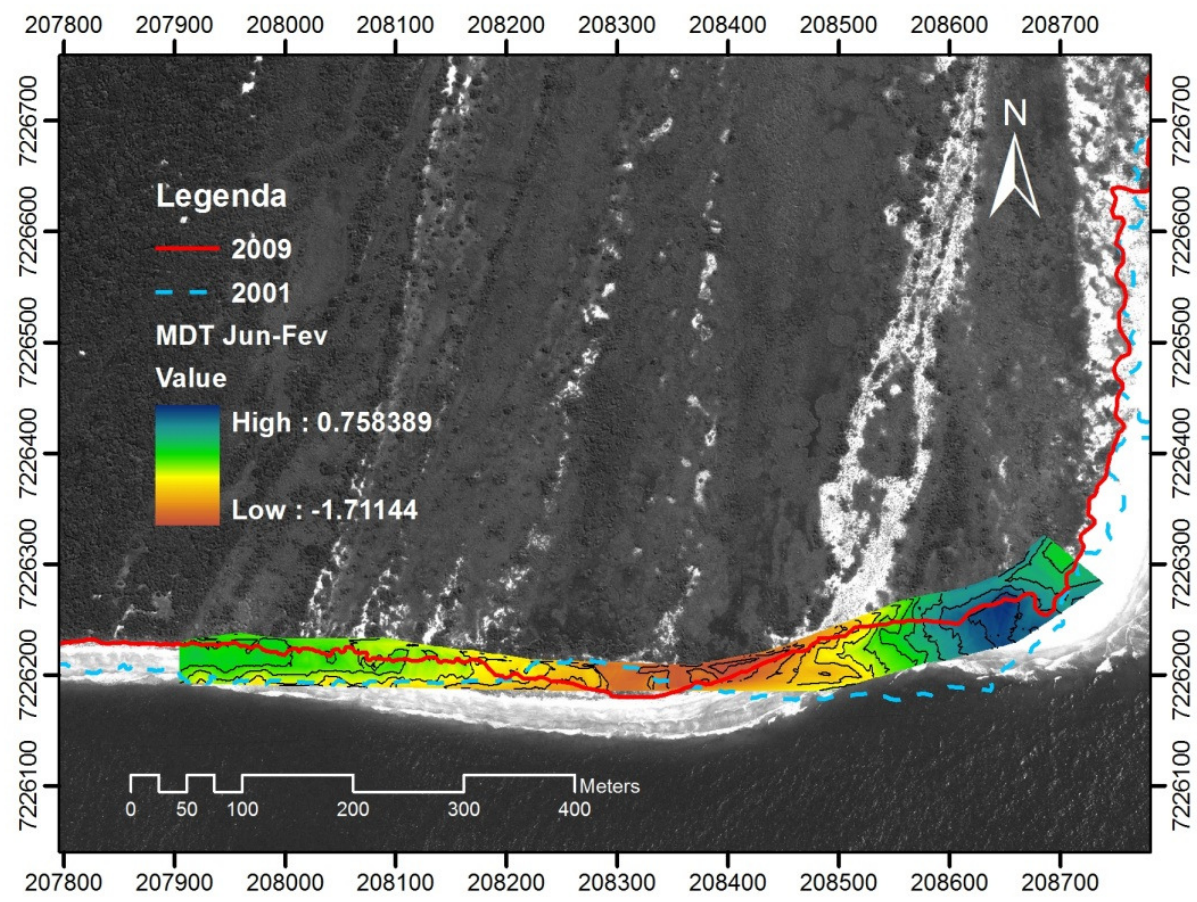

Figura 112: Sobreposição das Linhas de Costa de 2001 e 2009 ao MDT referente a comparação entre o primeiro e o último levantamento topográfico. Imagem de satélite de 2009 ao fundo. 
A acresção constante que a Área Leste vem sofrendo desde 1963 evidencia o domínio do transporte rumo NE. Os resultados dos MDTs e das variações volumétricas estão de acordo com este padrão, exibindo tendências acrescivas na escala sazonal. As variações volumétricas também indicam que os sedimentos provenientes da erosão da margem do canal sozinhos não explicariam a amplitude da acresção observada na Área Leste, sendo as fontes prováveis tanto as margens do canal e as porções internas do sistema estuarino-lagunar, quanto setores da costa mais ao Sul (Tessler et. al, 1990).

As fotografias e imagens aéreas utilizadas nas analises da evolução da linha de costa podem ser tratadas como retratos de etapas do processo de transposição da armadilha sedimentar condicionada a circulação hidrodinâmica da Desembocadura de Cananéia. Tal processo é um componente do grande ciclo de transporte de sedimentos para a direção NE, rumo a Desembocadura de Icapara, o qual, por sua vez pode ser relacionado com a própria gênese do Sistema Estuarino-Lagunar de Cananéia-Iguape.

O mecanismo de gatilho da transposição da Desembocadura de Cananéia parece ser a incidência de ondas vindas dos quadrantes S e SW combinadas com a sobre-elevação do nível do mar causada pelas marés meteorológicas. Essa mesma situação acaba por erodir também os sedimentos dispostos na margem de Ilha Comprida do canal da desembocadura, disponibilizando mais sedimentos para formação de bancos de areia. As feições sedimentares observadas durante a análise de escala temporal decadal são em ultima estância modeladas pelo equilíbrio entre a ocorrência de eventos meteorológicos intensos e ação das correntes de maré durante os ciclos temporais menores. O período de recorrência de ciclones extratropicais 
extremos e oscilações na intensidade desses seriam os fatores cotroladores para forma adquirida pela linha de costa e as feições adjacentes.

Os resultados da determinação das cotas de inundação indicam que os efeitos das modificações nos padrões de ocorrência e intensidade de eventos tempestuosos exerceriam mais efeitos sobre a região da Desembocadura de Cananéia que e o aumento do NRM proposto por IPCC ( 2007). Uma consequência plausível das mudanças climáticas em curso seria a intensificação dos processos erosivos atuantes na região do canal da desembocadura, bem como da transposição do sistema por meio do transporte dos bancos de areia. No entanto, tal situação pode não acarretar em uma maior acresção de sedimentos na praia de Ilha Comprida, visto que os efeitos erosivos das ondas geradas por ciclones extratropicais também são exercidos de forma efetiva nesse setor.

Para a determinação exata dos efeitos das mudanças climáticas globais na área de estudo se faz necessário uma análise do comportamento dos ciclones extratropicais na escala histórica, bem como a determinação dos efeitos das ondas associadas, em especial a relação entre as direções de ondas incidentes e os deslocamentos dos sistemas atmosféricos correspondentes. Seria interessante também a continuação das coletas de campo para se produzir uma série de dados mais robusta, permitindo assim acoplamentos melhores entre as diferentes escalas temporais e espaciais envolvidas nos processos sedimentares da região. 


\section{Conclusões}

As análises dos dados topográficos e volumétricos na escala diária indicou que a atuação das ondas de tempestades se deu principalmente na forma do transporte onshore-offshore em direção ao mar, ou seja, na retirada de sedimentos da face praial e a da ante praia em direção aos bancos localizados na face litorânea.

Os resultados referentes a escala mensal indicaram a predominância de processos erosivos na Área Sul, sendo estes resultantes da somatória da ação das correntes e marés e dos trens de onda incidentes. Apesar da natureza mais constante da influência das correntes de maré, os processos ligados a atuação de ondas geradas por ciclones extratropicais se mostraram mais efetivos na retira de sedimentos da Área Sul.

Os dados topográficos e volumétricos indicaram que a Área Leste e o Setor 1 apresentaram o comportamento clássico de ambientes sujeitos a dominância de processos marinhos nas escalas mensais e sazonais. As duas áreas demonstram uma tendência acresciva em face a diminuição da energia das ondas incidentes, fenômeno este causado pela variação das condições atmosféricas associadas as ao ciclo sazonal das estações climáticas. A similaridade dos resultados encontrados para as duas áreas evidencia 0 caráter local das influências exercidas pelas presenças da llha do Bom Abrigo e da Desembocadura de Cananéia.

Os resultados das análises de linha de costa na escala decadal estão de acordo com os resultados levantados nos trabalhos prévios, indicando que não houve mudanças significativas nos processos controladores da dinâmica sedimentar local. 
Devido o bom grau de compatibilidade entre os resultados encontrados, foi possível realizar análises integradas para se estabelecer o panorama geral da dinâmica sedimentar estabelecida e o papel dos processos atuantes nas diferentes escalas espaço-temporais. Através dos resultados destas análises pode se inferir que a presença da Desembocadura de Cananéia e da Ilha do Bom Abrigo confere ao sistema características de uma grande "armadilha sedimentar". Está armadilha aprisionaria os sedimentos transportados pelas correntes de deriva litorânea predominante de rumo NE, associada a atuação de sistemas frontais.

Os bancos presentes na forma de deltas de maré vazante são a expressão fisiográfica do processo de captura dos sedimentos provindos de setores mais ao Sul da costa. O processo de formação dos deltas estaria associado ao transporte onshore-offshore em direção a costa promovido pelas ondulações de NE e E somado ao transporte de sedimentos promovido pela ação das marés. A incidência das ondas de tempestades, especialmente as com direções S e SW somadas ao fenômeno da maré meteorológica, promoveriam tanto a erosão dos deltas através da deriva litorânea, quanto a disponibilização de sedimentos da margem do canal para o transporte das correntes de maré, e posterior formação de novos deltas de maré vazante.

Esta situação aponta a incidência de sistemas atmosféricos intensos como evento gatilho para a transposição da Desembocadura de Cananéia, transportando tanto os sedimentos provindos da Ilha do Cardoso e áreas mais ao sul, quanto os sedimentos advindos dos processos erosivos nas margens internas do sistema estuarino-lagunar. Tais processos podem ser relacionados até mesmo com a gênese do Sistema Estuarino-Lagunar Cananéia-Iguape. 
Os resultados ainda indicam processos erosivos incipientes nas adjacências da curva fisiográfica do canal em Ilha Comprida a parir de 2001, interrompendo a tendência de acresção observada desde os anos 50. Uma possível intensificação das tempestades pode explicar este processo, apontando para as mudanças climáticas em curso como causa. No entanto, a situação de erosão pode estar contida em uma escala temporal menor dos dados topográficos, sendo reflexo de um ano com incidência de ciclones extratropicais mais intensos.

A determinação das cotas de inundação indicou que mudanças na frequência e nas intensidades dos eventos atmosféricos intensos tem maior potencial para impactar a dinâmica sedimentar estabelecida que a aceleração da elevação do NRM. Esta consideração reforça a hipótese das mudanças nos ciclos de tempestades como causa do processo erosivo observado nas adjacências da Desembocadura de Cananéia. Contudo, são necessários estudos mais abrangentes para embasar melhor esta afirmação.

É provável que os processos erosivos observados na margem do canal e o processo de transposição da Desembocadura de Cananéia sejam intensificados pelo incipiente aquecimento global, mas a magnitude e a escala temporal com que tais impactos acontecerão carecem de estudos mais profundos para sua determinação com maior exatidão.

Apesar dos resultados obtidos apresentarem limitações, fica claro que somente a intensa dinâmica sedimentar local inviabiliza a ocupação humana sem supervisão nas imediações da Desembocadura de Cananéia, e os impactos decorrentes das mudanças ambientais em curso contribuem para que se adote ainda maior cautela. 


\section{Referências Bibliográficas}

AAGAARD, T. Multiple-bar morphodynamics and its relation to low-frequency edge waves. Journal of Coastal Research, 7(3):801-813. 1991.

ALMEIDA, F.F.M. \& CARNEIRO C.D.R. Origem e evolução da Serra do Mar. Revista Brasileira de Geociências, n. 28, p. 135-150. 1998.

ALVES JHGM. Numerical Modeling of Ocean Swell Contributions to the Global Wind-Wave Climate. Ocean Modelling. v.11. pp. 98-122. 2006.

ÂNGULO, J.R. Problemas na terminologia de ambientes subambientes litorâneos clásticos dominados por ondas. Boletim Paranaense de Geociências. v.44. pp. 51-57. 1996.

BAPTISTA, P; BASTOS, L. C.; BERNARDES, C. \& DIAS, A. A GPS based system for monitoring sand movements - The Aveiro Coastine Case. Littoral, The Changing Coast, p. 347-351. 2002.

BAPTISTA, P.B, BASTOS, L.C., BERNARDES, C.A., CUNHA, T.R. \& DIAS, J.A. Aplicação de Metodologia de Monitorização GPS em Litorais Arenosos. Geração de Modelos de Elevação do Terreno. Revista de Gestão Costeira Integrada, V. 8(1), p. 9-23. 2008.

BARCELOS, J. H. Sedimentação e subambientes deposicionais da ilha Comprida. 1975. 155 f. Dissertação (Mestrado). Instituto de Geociências, Universidade de São Paulo, São Paulo. 2 v. 1975.

BARLETTA, R.C. \& CALLIARI, L.J. An assesment of the atmospheric and wave aspects determining beach morphodynamic characteristics along the central coast of RS State, southern Brazil. Journal of Coastal Research. SI 35: 300308. 2003.

BARROS, M.O. DE \& TESSLER, M.G. Profile changes on Fazenda, Puruba and Itamambuca beaches, Ubatuba on the northern coast of São Paulo state, Brazil, as related to meteorological conditions. Journal of Coastal Research, V. 35, p. 184-183. 2003.

BENAVENTE, J.; DEL RÍO, L.; ANFUSO, G.; GRACIA, F.J.; REYES, J.L. Utility of Morphodynamic Characterization in the Prediction of Beach Damage by Storms. Journal of Coastal Research SI 36 56-64 (ICS 2002 Proceedings) Northern Ireland ISSN 0749-0208. 2002.

BENAVENTE, J.; DEL RÍO, L.; GRACIA, F.J. e MARTÍNEZ-DEL-POZO, J.A. Coastal flooding hazard related to storms and coastal evolution in Valdelagrana 
spit (Cadíz Bay Natural Park, SW Spain), Continental Shelf Research 26 (2006) 1061-1076. 2006.

BÉRGAMO, A.L. Características da hidrografia, circulação e transporte de sal: Barra de Cananéia, Sul do Mar de Cananéia e Baía de Trapandé. Dissertação de Mestrado, Universidade de São Paulo, Instituto Oceanográfico, USP, 210p. 2000.

BESNARD, W. Considerações gerais em tomo da região lagunar de CananéiaIguape. II. Diversos aspectos atuais da região lagunar. Boletim do Instituto Paulista Oceanográfico. v.1(2). pp.3-28. 1950.

BONETTI FILHO, Jarbas; MIRANDA, Luiz Bruner de. Estimativa da descarga de água doce no sistema estuarino-lagunar de Cananéia-Iguape. Brazilian Journal of Oceanography. São Paulo, v. 45, n. 1-2, 1997.

CALLIARI, L.J \& KLEIN, A.F.H. Características morfodinâmicas e sedimentológicas das praias oceânicas entre Rio Grande e Chuí, RS. Pesquisas, v.20(1), pp. 48-56. 1993.

CALLIARI, L.J.; MUEHE, D.; HOEFEL, F.G. E TOLDO JR., E. Morfodinâmica praial: uma breve revisão. Revista Brasileira de Oceanografia, v. 51, p. $63-78$. 2003.

CALLIARI, L.J.; TOZZI, H. M. \& KLEIN, A.H.F. Erosão associada a marés meteorológicas na costa sul-riograndense (COMEMIR/OSNLR). In: CONGRESSO BRASILEIRO DE GEOLOGIA, 39, Salvador. Salvador, SBG, Anais, 4:430 -434. 1993.

CALLIARI, L.J.; TOZZI, H.A.M. \& KLEIN, A.H.F. Beach morphology and coastline erosion associated with storm surge in Southern Brazil- Rio Grande to Chuí, RS. Anais da Academia Brasileira de Ciências, .v. 70, n. 2, 1998.

CAMPOS, R.M.; CAMARGO, R.D.E.; HARARI, E.J. Caracterização de eventos extremos do nível do mar em santos e sua correspondência com as reanálises do modelo do NCEP no sudoeste do atlântico sul. Revista Brasileira de Meteorologia, 25, 175-184. 2010.

CAPO, S.; PARISOT, J.P.; BUJAN, S e SÉNÉCHAL, N. Short time morphodinamics responses of Truc Vert Beach to storm condition. Journal of Coastal Research, SI 56 (Proceedings of the 10th International Coastal Symposium, Lisbon, Portugal), p. 10. 2009.

CAZZOLI Y GOYA, S. AND TESSLER, M.G, Variações morfológicas nas praias de Cibratel e Itanhaém. Revista Brasileira de Oceanografia, Universidade de São Paulo, Instituto Oceanográfico. São Paulo, 48 (2), 151 - 1 66. 2000. 
CERC (Coastal Engineering Research Center). Shore Protection Manual. Washington, U. S. Army Corps of Engineers. 4 volumes. 1973

CERC (Coastal Engineering Research Center). Beach and nearshore survey data: 1985 - 1991 CERC field research facility. Washington, U. S. Army Corps of Engineers. 26 p. 1993.

CERC (Coastal Engineering Research Center). Coastal Engineering Manual. Engineer Manual 1110-2-1100, U.S. Army Corps of Engineers, Washington, D.C. (in 6 volumes). 2002.

CHURCH, J.A., WHITE N.J. A 20th century acceleration in global sea-level rise. Geophysical Research Letter. v. 33:L01602. 2006.

CENTRO TECNOLÓGICO DE HIDRÁULICA - CTH/USP. Observação das características das ondas do mar de Cananéia. Relatório de projeto do Laboratório de Hidráulica da Escola Politécnica da Universidade de São Paulo, Departamento de Aguas e Energia Elétrica da Secretaria de Serviços e Obras Públicas, São Paulo, 40 p., 1 mapa. 1973.

CONTI, L. A., ARAUjO, C. A. S., PAOLO, F. S., BARCELlOS, R. L., MAHIQUES, M. M., \& FURTADO, V. V. An Integrated GIS For Sedimentological and geomorphological analysys of a tropical lagoon environment. Barra da Cananéia inlet region,(Southeastern Brazil). Journal of Coastal Research. v.16. pp. 13-24. 2012.

MIRELLA, B. S. F. COSTA; DANIELE, L. B.MALLMANN; PATRÍCIA M. PONTES; ARAUJO, M. Vulnerability and impacts related to the rising sea level in the Metropolitan Center of Recife, Northeast Brazil. Pan-American Journal of Aquatic Sciences. V. 5(2), pp. 341-349. 2010.

DAEE (DEPARTAMENTO DE ÁGUAS E ENERGIA ELÉTRICA). Contribuições superficiais dos rios que desaguam no sistema estuarino de Iguape-Cananéia (Mar Pequeno, Mar de Cubatão e Baía de Trapandé). Diretoria da Bacia do Ribeira e Litoral Sul/DAEE. OF/B.R.B/053/87. 1987.

DAVIS, R.; FITZGERALD, D. M. Beaches and Coast. Blackwell publishing limited. 1 edição. 2004.

DEAN, R.G. Heuristic models of sand transport in the surf zone. In: CONFERENCE ON ENGINEERING DYNAMICS IN THE SURF ZONE. Sydney,. Proceedings. Sydney, Institute of Engineers, pp. 208-214. 1973.

DEAN, R.G. Equilibrium beach profiles: Characteristics and applications. Journal of Costal Research. v.7, pp. 53-84. 1991.

DOMINGUEZ, J. M. L. Ambientes Geológicos da Costa Brasileira - Capitulo 12b. In: Dal Ré Carneiro e outros. (Org.). Geologia do Brasil: v. , p. -. 2008. 
ELIAS, E. Morphodinamics of Texel inlet. Tese (Doutorado) - Universiteit Delft, Holanda, 2006.

EMANUEL, K. Increasing destructiveness of tropical cyclones over the past 30 years. Nature. v. 436, pp. 686-688. 2005.

EMERY, K.O. A simple method of measuring beach profiles. Lawrence, Limnology and Oceanography. v.6, pp. 90 - 93. 1961.

ESTEVES, L.S.; TOLDO JR., E.E.; DILENBURG, S.R. and TOMAZELLI, L.J. Long- and Short-Term Coastal Erosion in Southern Brazil. Journal Coast Research, SI 36, pp. 273-282. 2002.

FARINACEO, A. Impactos na dinâmica costeira decorrentes de intervenções em praias arenosas e canais estuarinos de áreas densamente ocupadas no litoral de São Paulo, uma aplicação do conhecimento a áreas não ocupadas. Tese (Doutorado), 217 f. Instituto Oceanográfico, Universidade de São Paulo. 2008.

FERNANDEZ, G.B.; PEREIRA, T.G; MUEHE, D. \& ROCHA, T.B. Aplicação de critérios morfodinâmicos na diferenciação de setores ao longo do arco praial entre Cabo Frio e Arraial do Cabo - RJ. VII Simpósio Nacional de Geomorfologia/ Regional Conference of Geomorphology. Goiânia, GO. 2006.

FERREIRA, O.; GARCIA, T.; MATIAS, A.; TABORDA, R. e DIAS, J.A.. An integrated method for the determination of set-back lines for coastal erosion hazards on sandy shores. Continental Shelf Research, v.26, 1030-1044. 2006.

FIGUEIREDO, S.A. \& CALLIARI, L.J. Washouts in the Central and Northern Littoral of Rio Grande do Sul State, Brazil: Distribution and Implications. Journal of Coastal Research SI 39 (ICS 2004 Proceedings), Brazil. ISSN 0749-0208, pp. 266-370. 2006.

FOLK, R. L. \& WARD W. C. Brazos River bar: a study in the significance of grain size parameters. Journal of Sedimentary Research v.27, pp. 3-26. 1957.

FONZAR, B.C. A circulação atmosférica na América do Sul: os grandes sistemas planetários e subsistemas regionais que atingem o continente: Localização e trajetórias. Caderno de Geociências, n. 11, pp. 11-33. 1994.

FREITAS, D.; ARAUJO, R.S.; KLEIN, A.H.F. \& MENEZES, J.T. Quantificação de perigos costeiros e projeção de linhas de costa futuras para a enseada do Itapocorói - SC. Brazilian Journal of Aquatic Science and Technology, v.14(1), p. 39-49. 2010.

GAN, M. A. \& RAO, V. B. Surface cyclogenesis over South America. Mon. Weather Reveiw.,119, 1293-1302. 1991. 
GEOBRÁS - GEOBRÁS SIA - Engenharia e Fundações. Complexo Valo Grande- Mar Pequeno- Rio Ribeira de 19uape.Relatório para o serviço do Vale do Ribeira. São Paulo, DAEE. 2 v. 1966.

GIOC,.Coastal Modelling System (SMC) - Reference and User Manual. State Coast-Office-Spanish Environmental Ministry and the University of Cantabria. 82p. [in Spanish]. 2003.

GÓMEZ-PUJOL, L.; ORFILA, A.; CAÑELLAS, A.; ALVAREZ-ELLACURIA, A.; MÉNDEZ, F.J.; MEDINA, R.; TINTORÉ, J. Morphodynamic Classification of Sandy beachs in low energy marine environment. Marine Geology, v.242, pp. 235 - 246. 2007.

GUEDES, C.C.F. Evolução Sedimentar Quaternária da Ilha Comprida, Estado de São Paulo. 2009. Dissertação (Mestrado). 133 f. Instituto de Geociências, Universidade de São Paulo, São Paulo. 2009.

GUZA, R. T. \& INMAN, D. L. Edge waves and beach cusps. Journal of Geophysics Research, v.80(21), pp. 2997-3012. 1975.

HALLERMEIER, R.J. Seaward limit of significant sand transport by waves: an annual zonation for seasonal profiles. Coastal Engineering Technical Aid No. 81-2U.S. Army Corps of Engineers, CERC. 1981

HARARI, J. \& MESQUITA, A.R. Tábuas das marés de Ubatuba, Santos e Cananéia para os anos de 2012 E 2013. Relatório Técnico Instituto Oceanográfico, v.56, pp. 1-27. 2011

HAYES, M.O. General morphology and sediment patterns in tidal inlets. Sedimentary Geology. SI 26. 139-156p. 1980.

HOEFEL, F. G. Morfodinâmica de praias arenosas oceânicas: uma revisão bibliográfica. Monografia de Graduação. 73 p. Fundação Universidade do Rio Grande. 1995.

HOLGATE, S.J; WOODWORTH, P.L. Evidence for enhanced coastal sea level rise during the 1990s. Geophysical Research Letters. v.31:L07305. 2004

HOSKINS, B.J. \& HODGES, K.I. A new perspective on Southern Hemisphere storm tracks. Journal of Climate. v.18. pp. 4108-4129. 2005.

IPCC - Intergovernamental Panel on Climate Change. Climate Change 2007: The physical science basis. Summary for Policymakers. Contribution of working group I to the 4th assessment report of the IPCC. 18 pp. 2007.

JOHNSON, D.W. Shore Processes and Shoreline Development. $1^{\text {st }}$ ed. [S.I]: Hofner, 548 p. 1919. 
JEVREJEVA, S.; MOORE, J.C.; GRINSTED, A.; WOODWORTH, P.L. Recent global sea level acceleration started over 200 years ago. Geophysical Research Letters. v.35:L08715. 2008.

KARNIOL-MARQUEZ, M.R. Morfodinâmica de um Segmento da Praia de llha Comprida, Litoral Sul do Estado de São Paulo. 2007. 123 f. Dissertação (Mestrado). Instituto Oceanográfico, Universidade de São Paulo, São Paulo, 2007.

KIRBY, J.T. \& ÖZKAN, H.T. Combined Refraction/Diffraction Model for Spectral Wave Conditions, REF/DIF S, Version 1.1. CACR Report. No. 94-04, University of Delaware, Department of Civil Engineering, Center for Applied Coastal Research, Newark, Delaware. 1994.

KLEIN, A.H.F. \& MENEZES, J.T. Beach Morphodinamics and Profile Sequence for a Headland Bay Coast. Journal of Coastal Research, v. 17, n4, pp. 812835. 2001.

KOMAR, P.D. Beach processes and sedimentation. New York. Prentice Hall, 429 p. 1976.

KOMAR, P. D. Beach processes and erosion - an introduction. 10: Komar, P. D \& Moore, 1. Reds. CRC Handbook of coastal processes and erosion. Boca Raton, CRC Press. p.1-20. 1983.

LANDIM, P.M.B., MONTEIRO, R. C. \& CORSI, A. C. Introdução à confecção de mapas pelo software SURFER ${ }^{\circledR}$. Geomatemática, Texto Didático 8, DGA,IGCE,UNESP/Rio Claro. 2000.

LIM, E.P. \& SIMMONDS, I. Southern hemisphere winter extratropical cyclone characteristics and vertical organization observed with the ERA-40 data in 1979 - 2001. Journal of Climate. v. 20, pp. 2675 - 2690. 2007.

LIU, P. L-F. \& LOSADA, I. J. El modelado matemático de la propagacion del oleaje em ingeniaría de costas. Ingeniería Del Água. v.7. pp. 1-10. 2000.

MACHADO, G.M.V. \& MUEHE, D. Caracterização morfo-sedimentar da praia e antepraia ao longo da orla costeira do Parque Nacional da Restinga de Jurubatiba- RJ. In: COGRESSO DA ASSOCIAÇÃO DE ESTUDOS DO QUATERNÁRIO, 10, Guarapari. Anais do X Congresso da ABEQUA. 2005.

MAIA, N.Z. Avaliação da Elevação do Nível do Mar e Riscos de Inundação Costeira Associados à Passagem de Ciclones no Balneário Hermenegildo, RS. Dissertação (Mestrado), 104 f. Instituto de Oceanografia, Universidade Federal do Rio Grande. 2011. 
MARTINS, C.M. Variações Morfológicas e Sedimentares de Curto Período em Perfis Praiais, Praia de Bertioga/SP. Dissertação (Mestrado), 161 f. Instituto Oceanográfico, Universidade de São Paulo. 2000.

MARTINS, C.M. Morfodinâmica de Praia Refletiva: Estudo de Caso na Praia da Sununga, Litoral Norte do Estado de São Paulo. Tese (Doutorado), 209 f. Instituto Oceanográfico, Universidade de São Paulo. 2006.

MASSELINK, G. Simulanting the Effects of Tides on Beach Morphodynamics. J. coast. Res., SPECIAL ISSUE NO. 15. Beach and Surf Zone Morphodynamics (SPRING 1993), pp. 180-197. 1993.

MASSELINK, G. \& SHORT, A.D. The effect of tide range on beach morphodynamics and morphology: a conceptual beach model. Journal of Coastal Research, v.9(3), pp. 785-800. 1993.

MELO, M.S. A formação Pariquera-Acu e Depósitos Relacionados: Sedimentação, Tectônica e Geomorfogênese. 1990. Dissertação (Mestrado). 211 f. Instituto de Geociências, Universidade de São Paulo, São Paulo. 1990

MESQUITA, A.R. Sea-Level Variations Along The Brazilian Coast: A Short Review. Journal of Coastal Research. Special Issue, 35, 21-31. 2003.

MESQUITA, A. R.; HARARI, J. Tides and tide gauges of Cananéia and Ubatuba - Brazil (Lat. 24ํ). São Paulo: Instituto Oceanográfico, Universidade de São Paulo, 1983. p. 1-14. (Relatório, 11). 1983.

MISHIMA, M.; YAMANAKA, N.; PEREIRA, O. M.; SOARES, F. C.; SINQUE, C.; AKABOSHI, S. \& JACOBSEN, O. Hidrografia do complexo estuarino-lagunar de Cananéia $\left(25^{\circ} \mathrm{S}, 048^{\circ} \mathrm{W}\right)$. São Paulo, Brasil. Salinidade e temperatura (1973 a 1980). Boletim do Instituto de Pesca, v.12(3), pp.109-121. 1985.

MOORE, L.J. Shoreline mapping techniques. Journal of Coastal Research, v.16(1), pp. 111-124. 2000.

MORTON, R.A. Factors Controlling Storm Impacts on Coastal Barriers and Beaches-A Preliminary Basis for Near Real-Time Forecasting. Journal of Coastal Research, v.18(3), pp. 486-501. 2002

MUEHE, D. Sedimentology and topography of a high energy coastal environment between Rio de Janeiro and Cabo Frio, Brazil. Anais da Academia Brasileira de Ciências (ISSN: 0001-3765), v.51(3), pp. 473-481. 1979.

MUEHE, D. Critérios Morfodinâmicos para o Estabelecimento de Limites da Orla Costeira para fins de Gerenciamento. Revista Brasileira de Geomorfologia, v.2 (1), pp. 35-44. 2001. 
MUEHE, D. Erosão Costeira - Tendência ou Eventos Extremos? O Litoral entre Rio de Janeiro e Cabo Frio, Brasil. Revista da Gestão Costeira Integrada. No prelo.

MUEHE, D. \& ALBINO, J. Erosão e recuperação de um pontal arenoso Macaé (RJ). In: CONGRESSO BRASELEIRO DE GEOLOGIA, 37, São Paulo, São Paulo, 1992. São Paulo, SGB, Anais, p.188. 1992.

MUEHE, D. \& CORRÊA, C.H.T. Dinâmica de praia e transporte de sedimentos ao longo da restinga da Massambaba. Revista Brasileira de Geociências, v.19(3), pp.387-392. 1989.

MUEHE, D. \& DÖBEREINER, C. Dinâmica do fundo marinho ao longo do pier de Ipanema, Rio de Janeiro. Anais da Academia Brasileira de Ciências, v. 49(2), pp. 281-286. 1977.

MIYAO, S.Y. Contribuição ao estudo da oceanografia física da região de Cananéia (lat. 25॰S long. 48॰W). Dissertação de Mestrado, 87 f. Instituto Oceanográfico, Universidade de São Paulo, São Paulo. 1977.

NASCIMENTO Jr., D. R. Morfologia e sedimentologia ao longo do sistema praia - duna frontal de Ilha Comprida, SP. Dissertação de Mestrado, 136 f. Instituto de Geociências, Universidade de São Paulo, São Paulo. 2006.

NUBER, E. Evolução morfológica e sedimentológica do Arco Praial de Massaguaçu, Litoral Norte de São Paulo. Dissertação (Mestrado), $143 \mathrm{f}$. Instituto Oceanográfico, Universidade de São Paulo. 2008.

ORTEL, G.F. Processes of sediment exchange between tidal inlets, ebb deltas and barrier islands. In: Hydrodynamics and Sediment Dynamics of Tidal Inlets, Lecture Notes on Coastal and Estuarine Studies, Vol. 29. D.G. Aubrey and L. Weishar (eds.). New York: Springer, pp. 297 318. 1988.

PARISE, C.K.; CALLIARI, L.J. e KRUSCHE, N. Extreme storm surges in the south of Brazil: atmospheric conditions and shore erosion. Brazilian Journal of Oceanography, v. 57(3), p.175-188. 2009.

PAOLO, F.S. \& MAHIQUES, M.M. Utilização de métodos acústicos em estudos de dinâmica costeira: Exemplo na desembocadura lagunar de Cananeia. Revista Brasileira de Geofísica, v.26(2), pp. 211-225. 2008.

PEREIRA, M.D.; SIEGLE, E.; MIRANDA, L.B.; SCHETTINI, C.A.F.. Hidrodinâmica e transporte do material particulado em suspensão sazonal em um estuário dominado por maré: estuário de Caravelas (BA) Revista Brasileira de Geofísica. v.28 (3), pp. 427-444. 2010. 
PEREIRA, P.S.; CALLIARI, L.J. e BARLETTA, R.C. Heterogeneity and homogeneity of Southern Brazilian beaches: A morphodynamic and statistical approach. Continental Shelf Research, v.30, pp. 270-280. 2010.

PETRI, S. \& SUGUIO, K . Exemplo de trabalho do mar no litoral sul do Brasil Notíc. geomorf.. v.11(21), pp. 61-66. 1971.

PEZZA, A.B. \& SIMMONDS, I. The first South Atlantic hurricane: Unprecedented blocking, low shear and climate change. Geophysical Research Letters. v.32, L15712. 2005.

PONÇANO, W.L.; TESSLER, M.G.; FREITAS, C.G.L. de \& MAHIQUES, M.M. Tendências regionais de transporte se sedimentos arenosos ao longo das praias paulistanas. Geociências. v.IV (6). pp. 102-115. 1999.

REBOITA, M. S. Ciclones Extratropicais sobre o Atlântico Sul: Simulação Climática e Experimentos de Sensibilidade. Tese de Doutorado, 359 f. Instituto de Astronomia, Geofísica e Ciências Atmosféricas, Universidade de São Paulo. 2008.

REBOITA, M.S.; IWABE, C.M.N.; DA ROCHA, R.P.; AMBRIZZI, T. Análise de um Ciclone Semi-Estacionário na Costa Sul do Brasil Associado a Bloqueio Atmosférico. Revista Brasileira de Meteorologia. v.24(4). pp. 407-422. 2009.

ROGACHESKI, C.E. A dinâmica sedimentar e a caracterização de Zonas de Erosão Acentuada (ZEA) ao longo do arco praial de Massaguaçu, SP. Dissertação de Mestrado, 167 f. Instituto Oceanográfico, Universidade de São Paulo. 2010.

SADOWSKY, V. Observações sobre as modificações em curso na entrada de Cananéia, de sua barra e da região adjacente. I. Desgaste das costas. Ponta da Trincheira (1952). Boletim do Instituto Oceanográfico. São Paulo. v.3 (1/2), pp. 201-212. 1952.

SADOWSKY, V. Novas contribuições ao estudo da entrada da barra de Cananéia. Boletim do Instituto Oceanográfico. São. Paulo. v.4(1/2), pp. 151177. 1954.

SAVI, D.C. Erosão e Acresção Costeira na Enseada dos Anjos, Arraial do Cabo, RJ. Revista Brasileira de Geofísica, v. 25, n.1, pp. 91 - 99. 2007.

SÉNÉCHAL, N.; GOURIOU, T.; CASTELLE, B.; PARISOT, J.-P.; CAPO, S.; BUJAN, S.; HOWA, H. Morphodynamic response of a meso- to macro-tidal intermediate beach based on a long-term data set. Geomorphology, v.107, pp. 263-274. 2009. 
SHORT, A. D. Wave power and beach stages: A global model. In: INTERNATIONAL CONFERENCE ON COASTAL ENGINEERING, 16. Hamburg, 1978. Proceedings. Hamburg, ASCE. pp. 1045-1062. 1979a.

SHORT, A. D. Three dimensional beach stage model. Journal of Geology, v.87(5), pp. 553-571. 1979b.

SHORT, A. D. Beach response to variation in breaker height. In: INTERNATIONAL CONFERENCE ON COASTAL ENGINEERING, 17. Sydney, 1981. Proceedings. Sydney, ASCE. p. 1016-1035. 1981.

SHORT, A. D. Macro-meso tidal beach morphodynamics - an overview. Journal of coastal Research, v.7(2), pp. 417-436. 1991.

SHORT, A. D. Beach systems of the central Netherlands coast: processes, morphology and structural impacts in a storm driven multi-bar system. Marine Geology, v.107(1-2), pp.103-137. 1992.

SHORT, A. D. Handbook of Beach and Shoreface Morphodynamics. John Wiley and Sons, Chischester(1993), 379 f. 1999.

SHORT, A. D. \& AAGAARD, T. Single and multibar beach change models. Journal of Coastal Research, v.15, pp. 141-157. 1993.

SHORT, A. D. \& Wright, L. D. Beach systems of the Sydney region. Australian Geography, v.15, pp. 8-16. 1981.

SIEGLE, E. \& CALLIARI, L.J. High-energy events and short-term changes in superficial beach sediments. Brazilian Journal of Oceanography, v. 56(2), pp. 149 - 152. 2008.

SONU, C.R.G. \& VAN BEEK, J.L. Systematic beach changes in the outer banks, North Carolina. Chicago. Journal of Geology, 74, pp. 416 - 425. 1971.

SOUSA, C.R. de G. As células de deriva litorânea e erosão nas praias do Estado de São Paulo. 1997. Tese (Doutorado). Instituto de Geociências, Universidade de São Paulo, São Paulo. 2 v. 1997.

SOUZA, L. A. P.; M. G. TESSLER \& V. L.GALLI. O gráben de Cananéia. Revista Brasileira de Geociências, 26(3): 139-150. 1996.

SIEGLE, E. \& CALLIARI, L.J. High-Energy events and short-term changes in superficial beach sediments. Brazilian Journal of Oceanography.,v.56(2), pp. 149-152. 2008.

SPINELLI, F.P. As rochas alcalinas de Cananéia, litoral sul do Estado de São Paulo; características petrográficas, mineralógicas e geoquímicas. 2003. Dissertação (Mestrado). 134 f. Instituto de Geociências, Universidade de São Paulo, São Paulo. 2003. 
SUGUIO, K. Introdução a sedimentologia. São Paulo, Edgard Blucher, 317 f. 1973

SUGUIO, K.; MARTIN, L. Formações quaternárias marinhas do litoral paulista e sul fluminense. In: INTERNATIONAL SYMPOSIUM ON COASTAL EVOLUTION IN THE QUATERNARY, 1., 1978. São Paulo. Special Publication...São Paulo: IGCB/IG-USP/SBG, 55 p. 1978.

SUGUIO, K.; PETRI, S. Stratigraphy of the Iguape-Cananéia lagoonal region sedimentary deposits, São Paulo state, Brazil. Part I: field observations and grain size analysis. Boletim do Instituto de Geociências, v.4, pp. 1-20. 1973.

SUGUIO, K. \& TESSLER, M. G. Intense coastal sedimentation and erosion in the Cananéia outlet, southern State of São Paulo, Brazil. Boletim do Instituto Oceanográfico. v.32(1), pp. 71-75. 1983.

SURFER 9. Users Guides/ Contouring and 3D Surface Mapping for Scientists and Engineers, Golden Software, Inc. 639p. 2009.

TABAJARA, L.L.; MARTINS. L.R. \& ALMEIDA, L.E.S.B. Resposta e Recomposição das Praiais e Dunas após Sequencia de Ciclones Extratropicais. GRAVEL, ISSN 1678-5975 N², pp. 102-121. 2004.

TAGLIANI, C.R.A; CONTERATO, M.R.; ANTIQUEIRA, J.A.F.; CALLIARI, L.J.; TAGLIANI, P.R. e SOARES, M.N. Construção de um Modelo de Elevação Digital de Terreno para a llha dos Marinheiros, Rio Grande, RS, com o uso de DGPS e Rotinas de Geoprocessamento. GRAVEL, ISSN 1678-5975 N4, pp 89-98. 2006.

TESSLER, M.G. Dinâmica sedimentar quaternária no litoral sul paulista, estado de São Paulo. 277 f. Tese (Doutorado) - Instituto de Geociências, Universidade de São Paulo, São Paulo. 2 v. 1988.

TESSLER, M.G.\& GOYA, S.C. Conditioning factors of coastal processes in the Brazilian Coastal Area. Revista do Departamento de Geografia, v.17, pp. 11-23, 2005.

TESSLER, M.G.; K. SUGUIO, M.M. MAHIQUES, \& V.V. FURTADO. Evolução temporal e espacial da desembocadura lagunar de Cananéia (SP). Boletim do Instituto Oceanográfico. v.38 (1), pp. 23-29. 1990.

TESSLER, M.G. \& SOUZA, L.A.P. Dinâmica sedimentar e feições sedimentares identificadas na superfície de fundo do sistema Cananéia-Iguape, SP. Revista Brasileira de Oceanografia, v.46(1), pp. 69-83. 1998.

TOLDO JR, E. E.; DILLENBURG, S. R.; ALMEIDA, L. E. S. B.; TABAJARA, L. L.; MARTINS, R. e CUNHA, L. O. B. P. Parâmetros morfométricos da Praia de Imbé, RS. Pesquisas, v.20(1), pp. 27-32. 1993. 
TRUCCOLO E.C., FRANCO D. \& SCHETTINI C.A.F. The Low Frequency Sea Level Oscillations in the Northern Coast of Santa Catarina, Brazil. Journal of Coastal Research, v.39(SI), pp. 547-552. 2006.

TURNER, I.L. \& MASSELINK, G. Swash infiltration-exfiltration and sediment transport. Journal of Geophysical Research. v.103(C13), 30, 813-30, 824. 1998.

VEIGA, A.J.P.; PEZZA, A.B.; SIMMONDS, I.; SILVA DIAS, P.L. An analysis of the energetics on the transition of the first South Atlantic Hurricane. Geophysical Research Letters, v.35: L15806. 2008.

VIEIRA DA SILVA, G. Cota de Inundação e Recorrência para a Enseada do Itapocorói e praia de Morro dos Conventos, Santa Catarina. Dissertação (Mestrado). 98 f. Instituto de Geociências. Universidade Federal do rio Grande do Sul. 2012.

WANG, X.L.; SWAIL, V.R.; ZWIERS, F.W. Climatology and changes of extratropical cyclone activity: comparison of ERA-40 with NCEP/NCAR reanalysis for 1958-2001. Journal of Climate, v.19, pp. 3145-3166. 2006.

WRIGHT, L. D.; THORN, B. G. \& CHAPPELL, J. Morphodynamic variability of high energy beaches. In: INTERNATIONAL CONFERENCE ON COASTAL ENGINEERING, 16. Hamburg, 1978. Proceedings. Hamburg, ASCE, pp. 11801194. 1978.

WRIGHT, L. D.; SHORT, A. D. Morphodynamic variability of surf zones and beaches: a synthesis. Marine Geology, v.56(1/4), pp. 93-118. 1984.

WRIGHT, L. D.; SHORT, A. D. \& GREEN, M. O. Short term changes in the morphodynamic states of beaches and surf zones: an empirical predictive model. Marine Geology, v.62(3-4), pp. 339-364. 1985.

WRIGHT, L. D. \& SHORT, A. D. Morphodynamics of beaches and surf zones in Australia. In: Komar P. D. ed. Handbook of coastal processes and erosion. Boca Raton, CRC Press, pp. 35-64. 1983.

WRIGHT, L. D.; CHAPPELL, J.; THORN, B.G.; BRADSHAW, M. P. \& COWELL, $P$. Morphodynamics of refletive and dissipative beach and inshore systems: Southeastern Australia. Marine Geology, v.32(1-2), pp.105-140. 1979.

WRIGHT, L.D.; GUZA, R.T.; SHORT, A.D. Dynamics of a high energy dissipative surf zone. Marine Geology, v.45, pp. 41-62. 1982

ZALAN, P.V.; OLIVEIRA, J.A.B. Origem e evolução estrutural do Sistema de Riftes Cenozóicos do Sudeste do Brasil. Boletim de Geociências da Petrobrás. N. 13, pp. 269-300. 2005. 


\section{Anexo I}

Neste anexo encontram-se dispostos os mapas produzidos para ilustrar as diferenças altimétricas mensais entre os levantamentos realizados. Os mapas são compostos pela subtração entre o MDE do mês mais recente e o MDE do mês de data mais antiga, sempre nesta ordem, e também pela sobreposição de perfis praias dos respectivos meses, retirados dos MDE confeccionados em ambiente SURFER ${ }^{\circledR} 9$.

Os dados se encontram em três seções:

- Setor 2 - Área Leste;

- Setor 2 - Área Sul;

- Setor 1. 
1 - Escala Mensal : Setor 2 - Área Leste

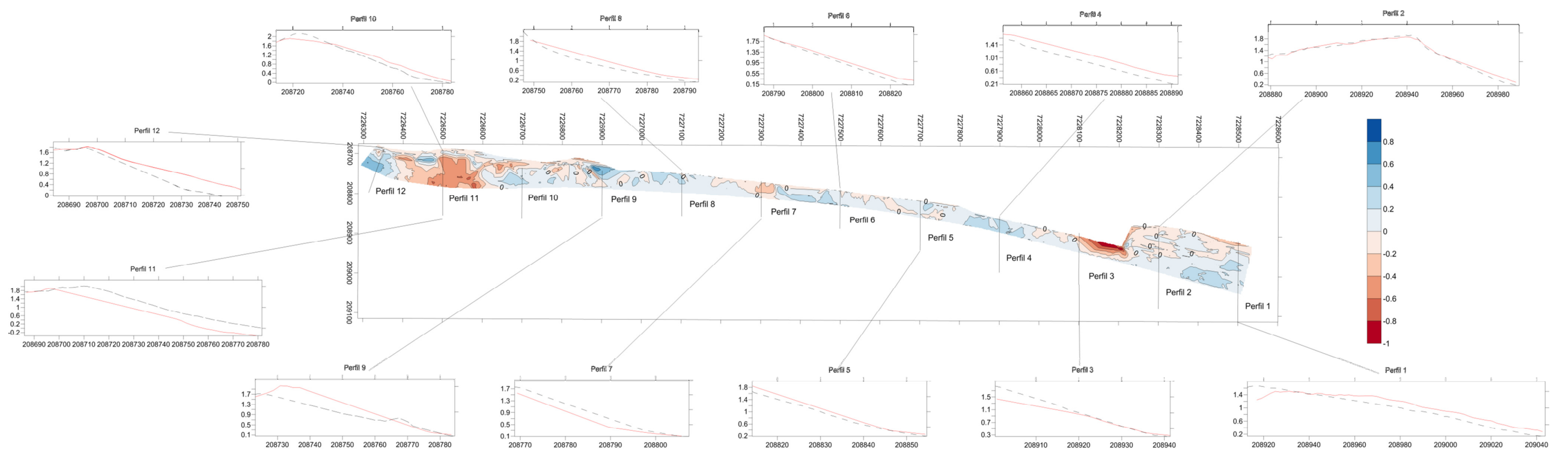

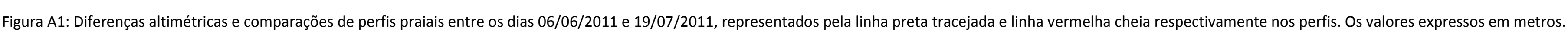

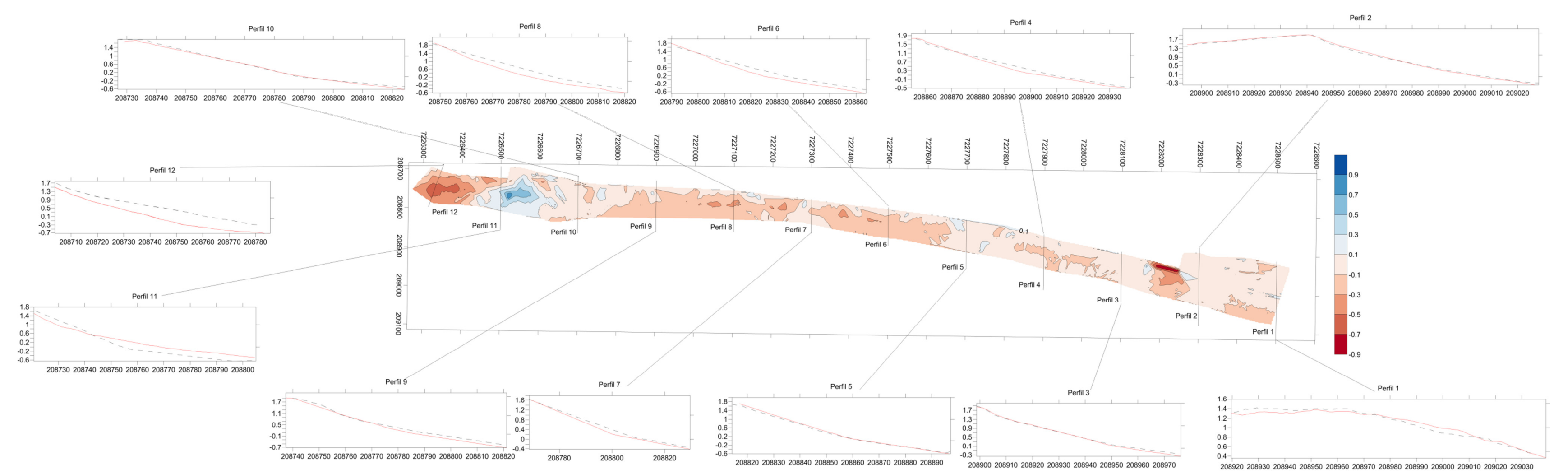

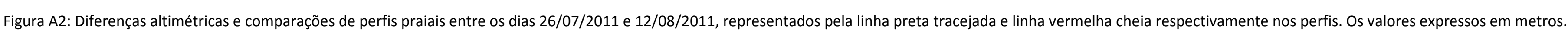




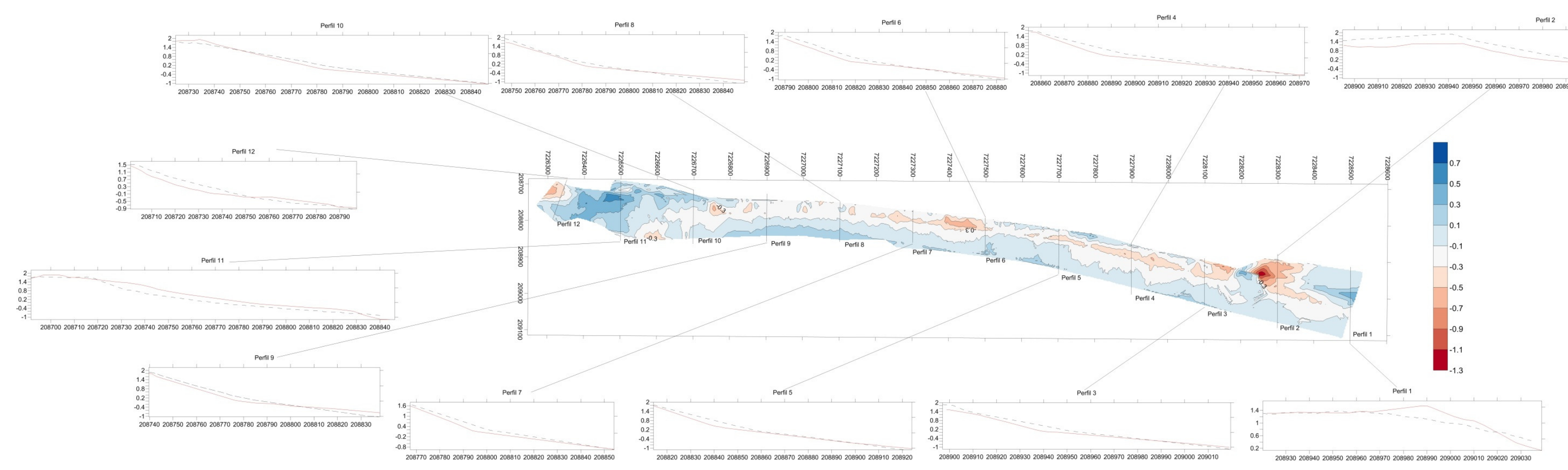

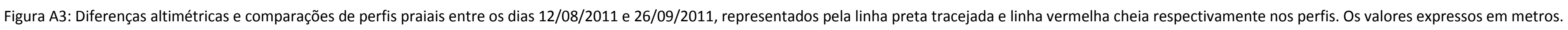

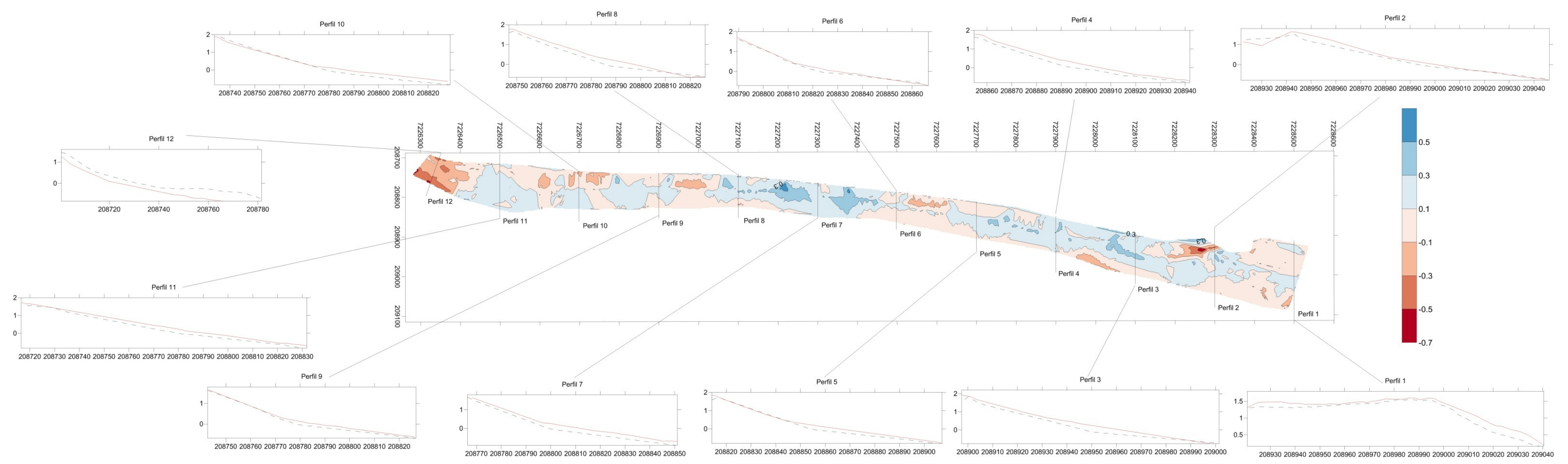

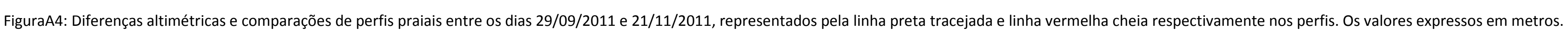




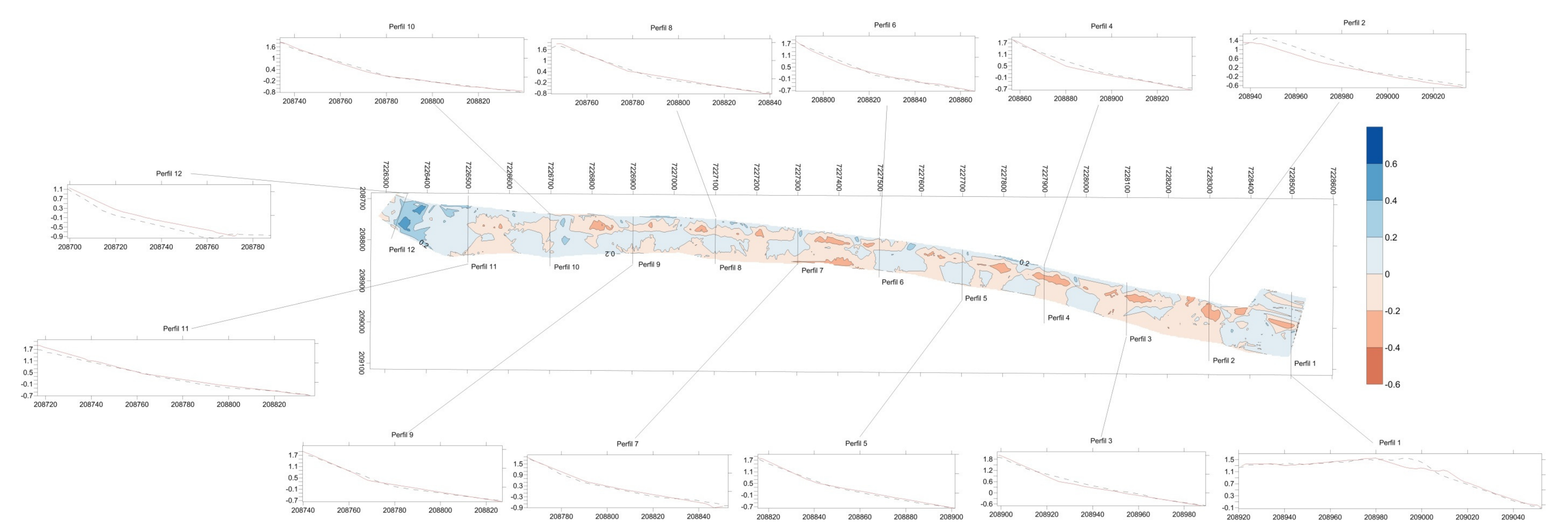

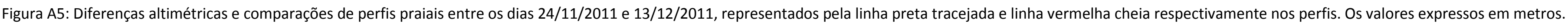

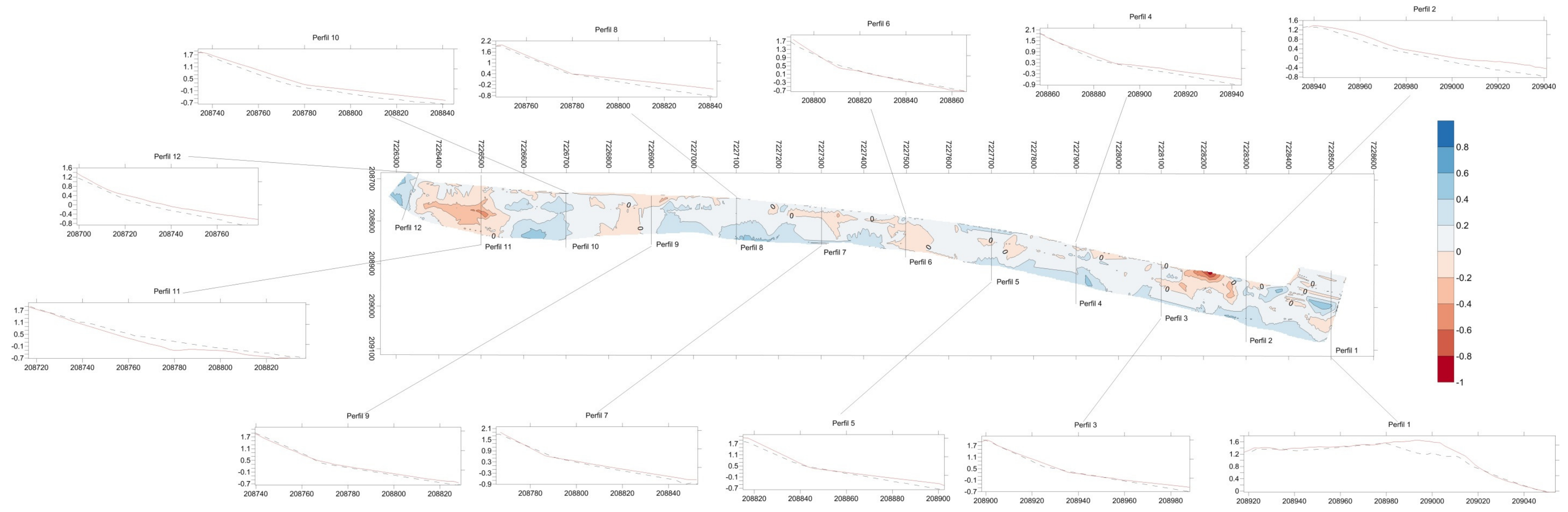

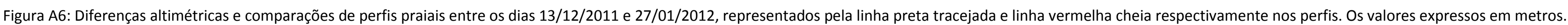




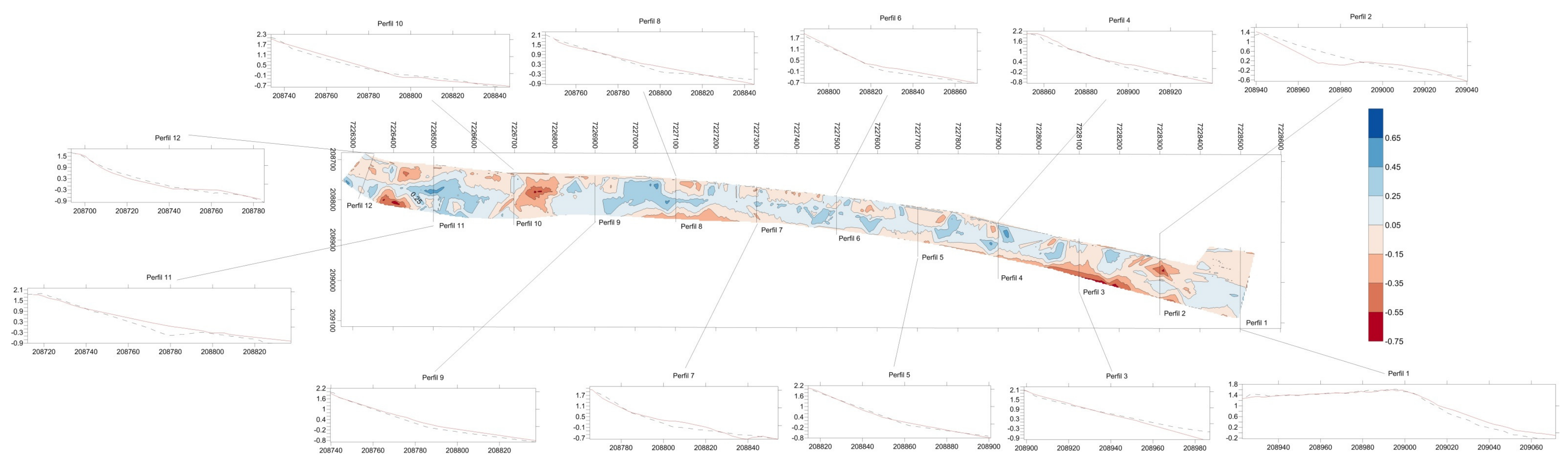

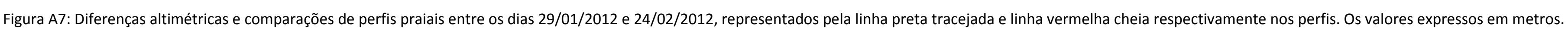

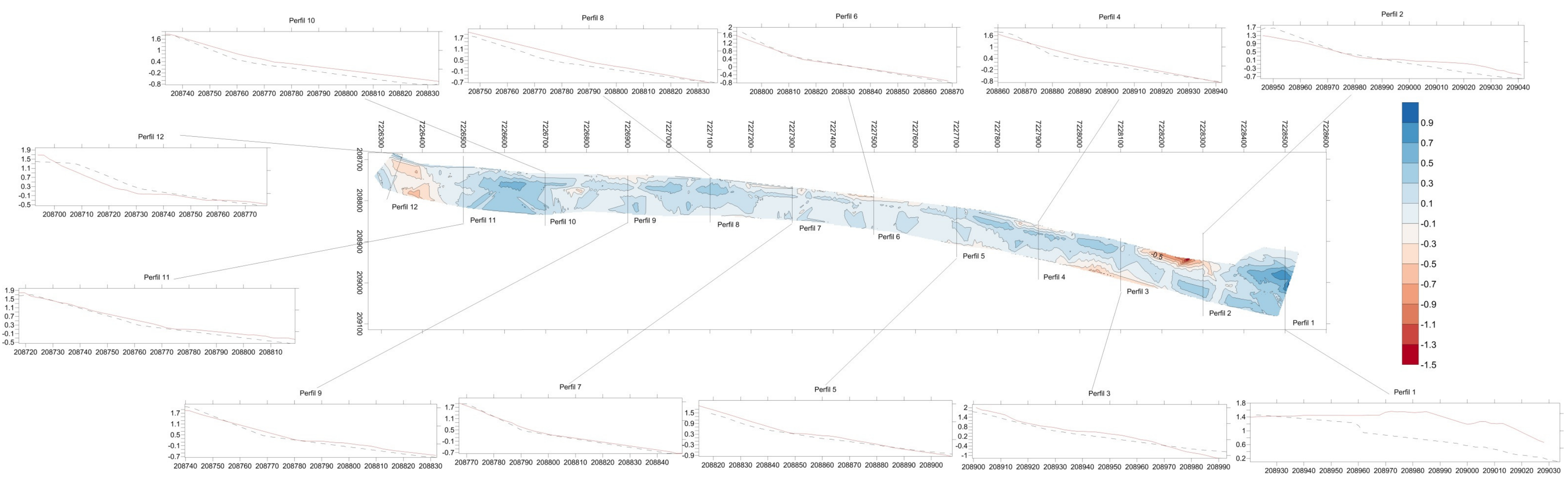

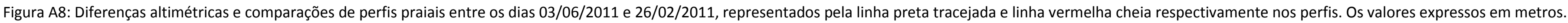


2. Setor 2 - Área Sul

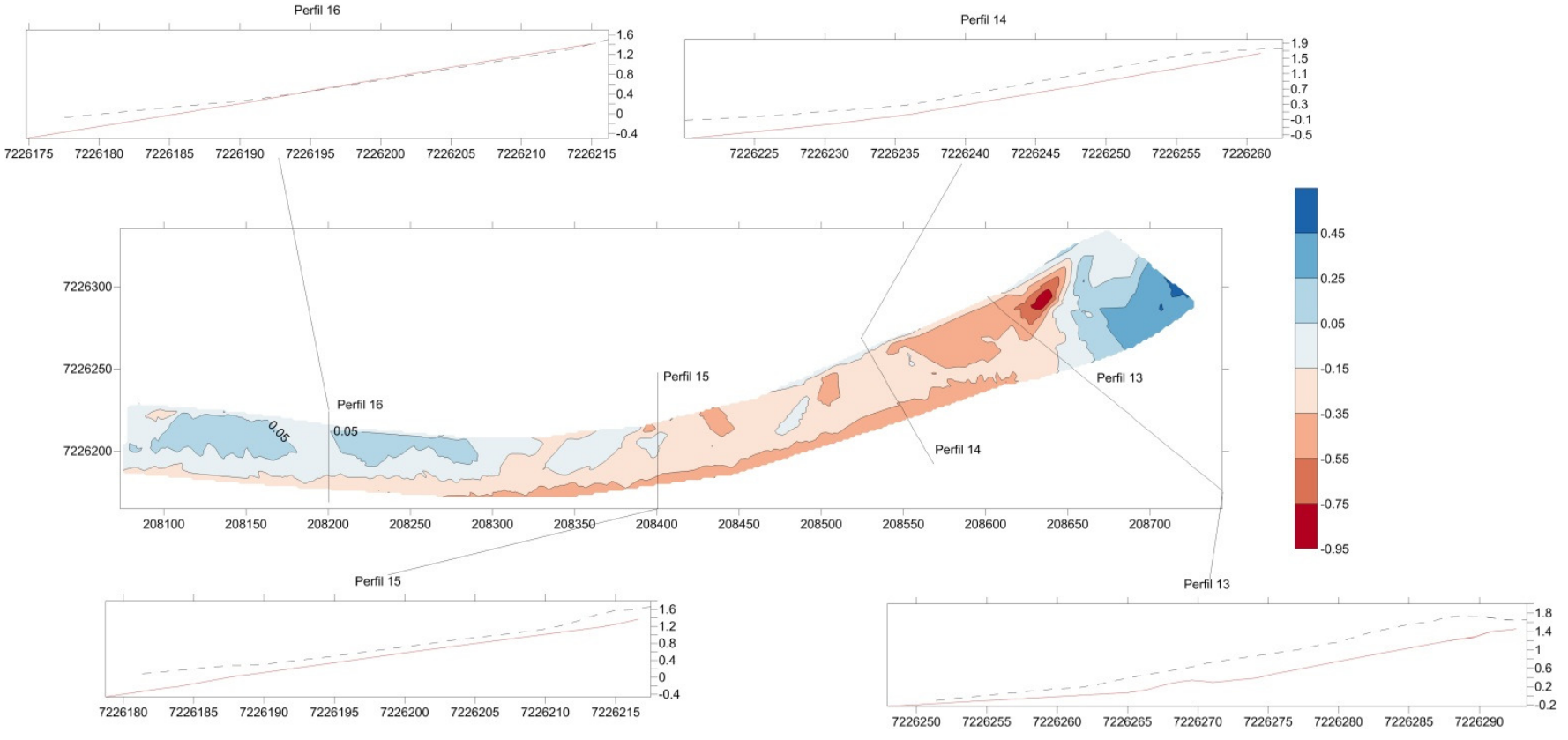

Figura A7: Diferenças altimétricas e comparações de perfis praiais entre os dias 06/06/2011 e 19/07/2011, representados pela linha preta tracejada e linha vermelha cheia respectivamente nos perfis. Os valores expressos em metros.

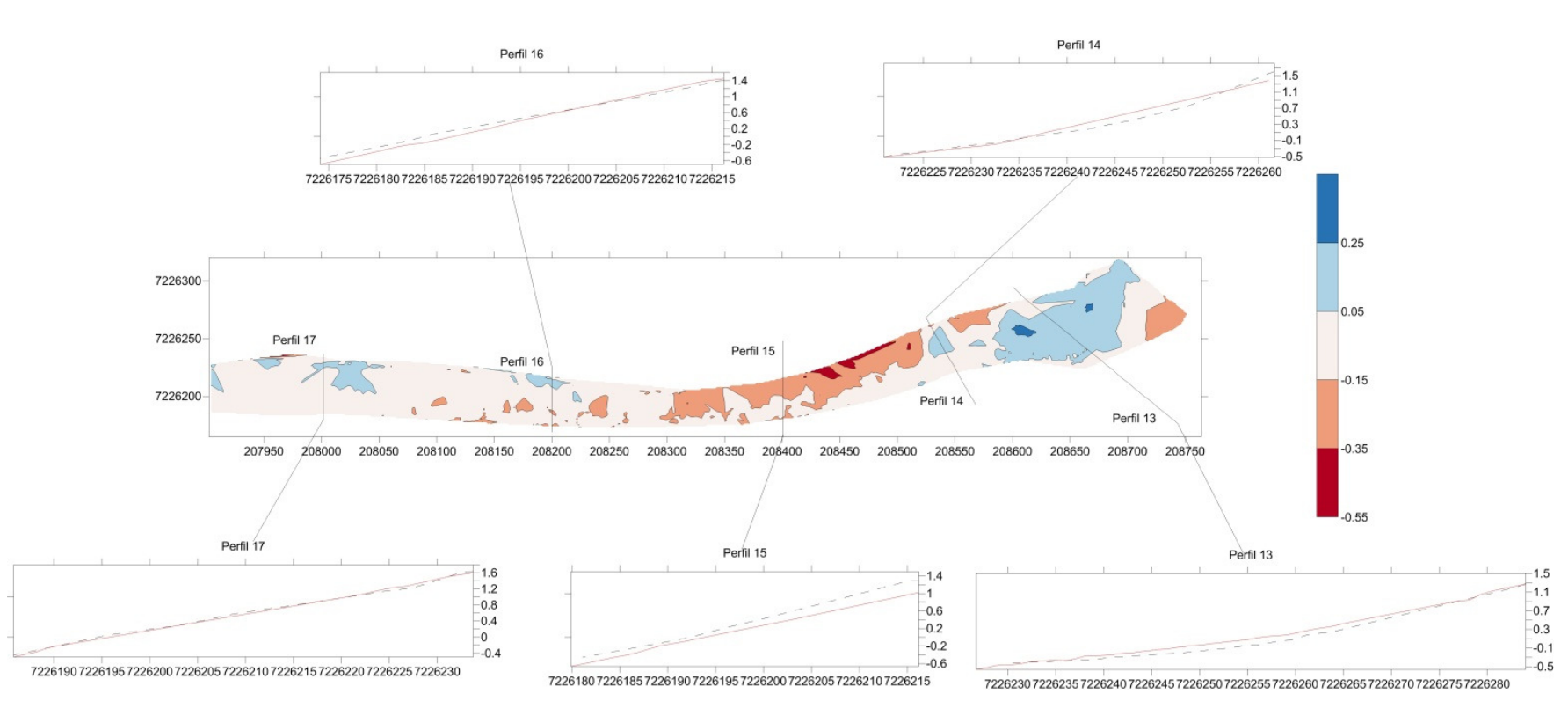

Figura A8: Diferenças altimétricas e comparações de perfis praiais entre os dias 27/07/2011 e 12/08/2011 representados pela linha preta tracejada e linha vermelha cheia respectivamente nos perfis. Os valores expressos em metros.

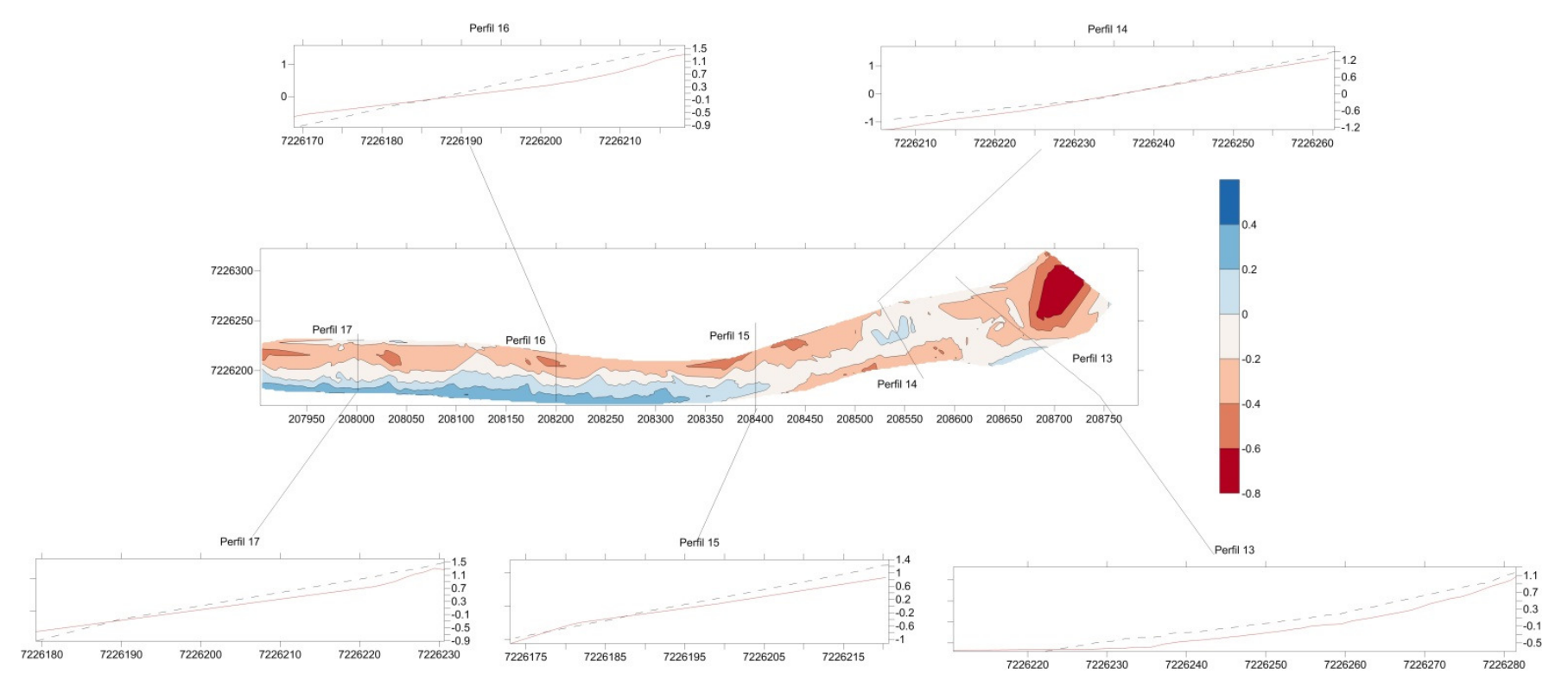

Figura A9: Diferenças altimétricas e comparações de perfis praiais entre os dias 12/08/2011 e 27/09/2011, representados pela linha cheia e linha tracejada respectivamente nos perfis. Os valores expressos em metros.

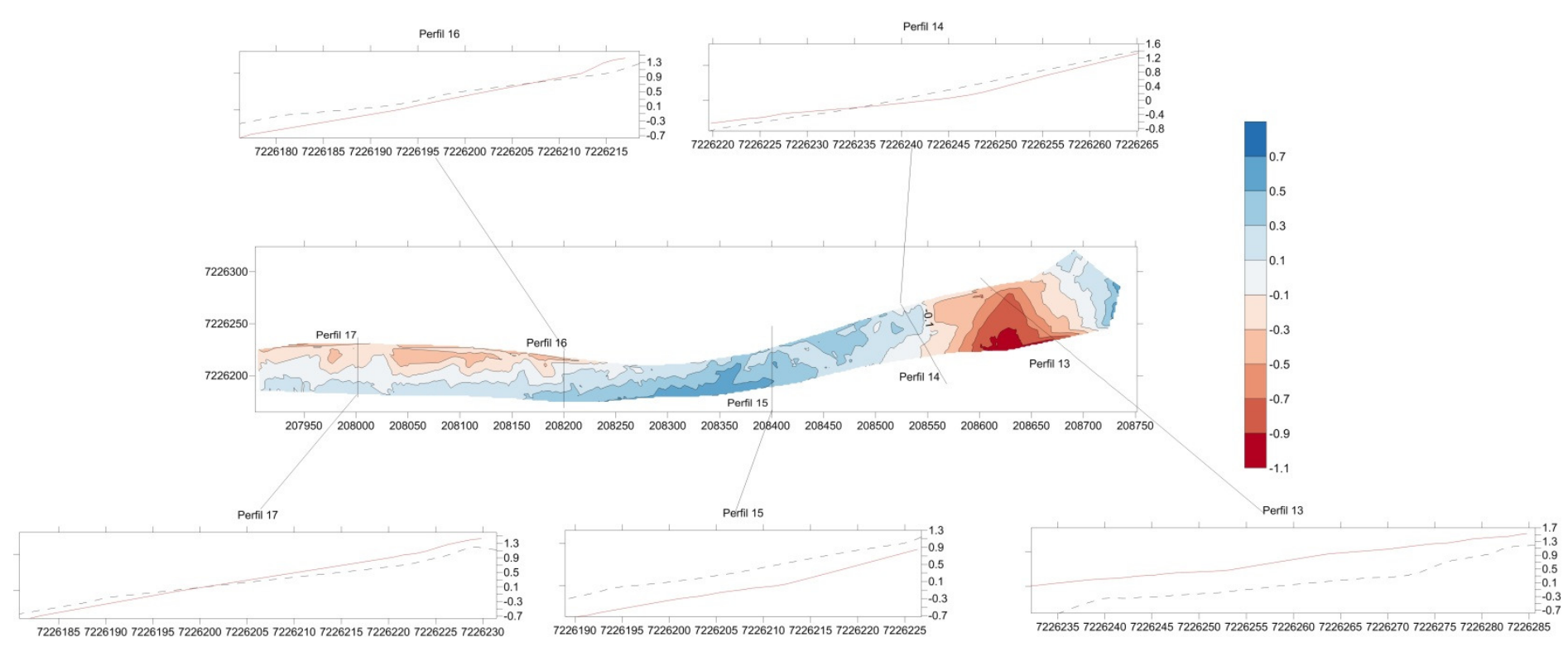

Figura A10: Diferenças altimétricas e comparações de perfis praiais entre os dias 29/09/2011 e 21/11/2011 representados pela linha preta tracejada e linha vermelha cheia respectivamente nos perfis. Os valores expressos em metros. 

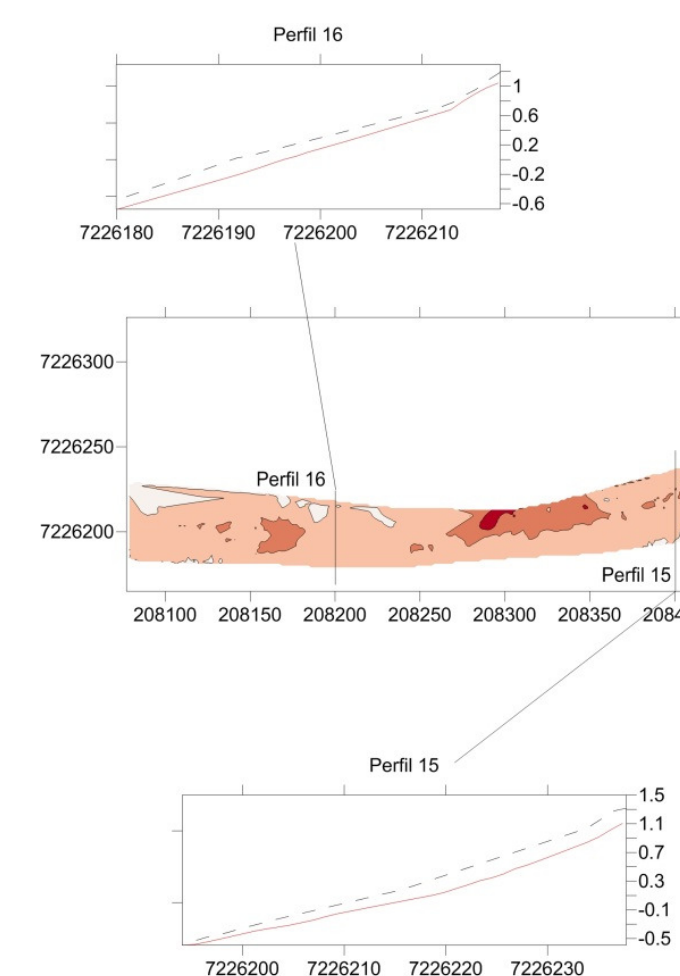

Figura A11: Diferenças altimétricas e comparações de perfis praiais entre os dias 24/11/2011 e 13/12/2011, representados pela linha preta tracejada e linha vermelha cheia respectivamente nos perfis. Os valores expressos em metros.

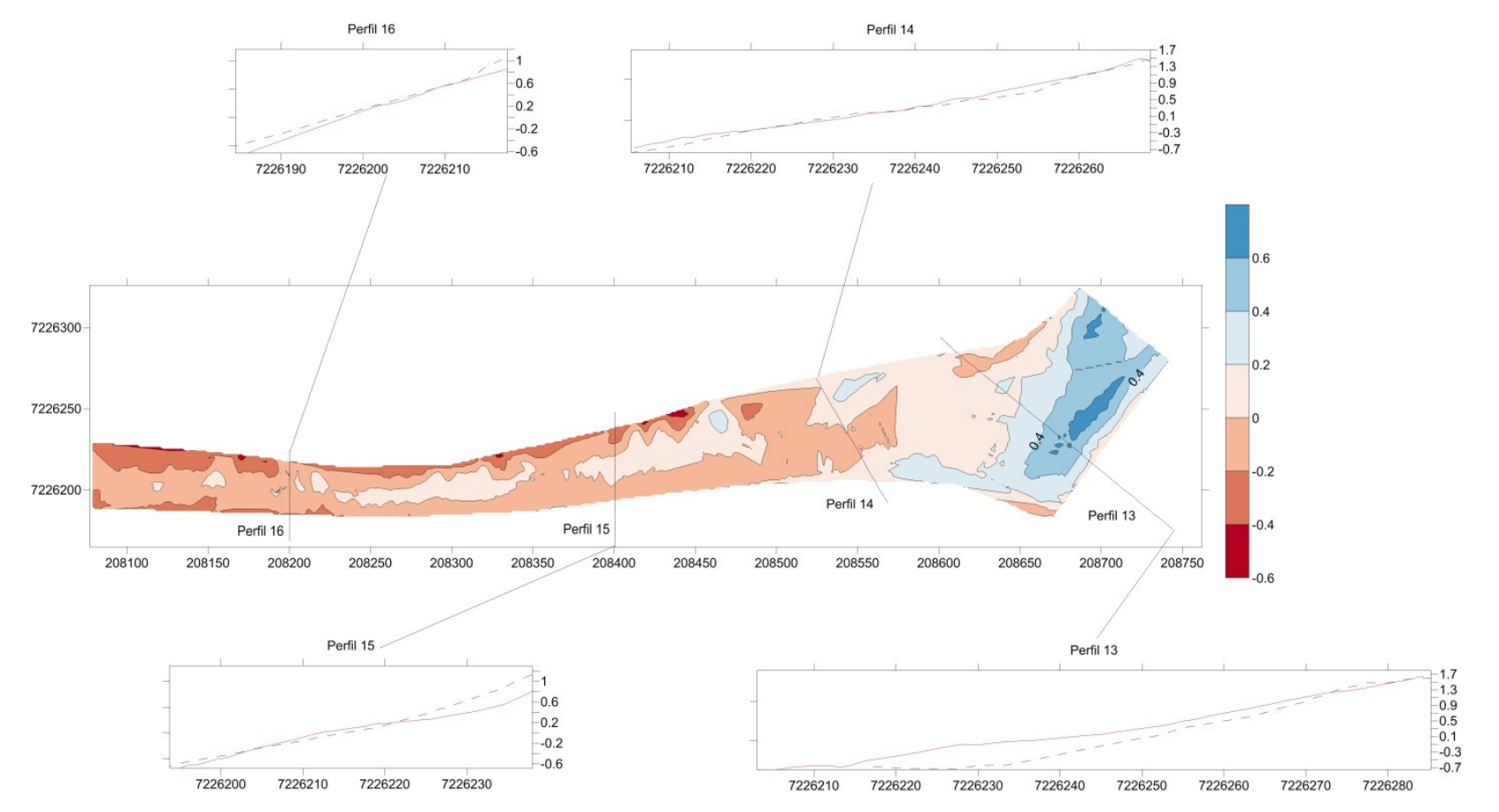

Figura A12 Diferenças altimétricas e comparações de perfis praiais entre os dias 13/12/2011 e 27/01/2012, representados pela linha preta tracejada e linha vermelha cheia respectivamente nos perfis. Os valores expressos em metros.

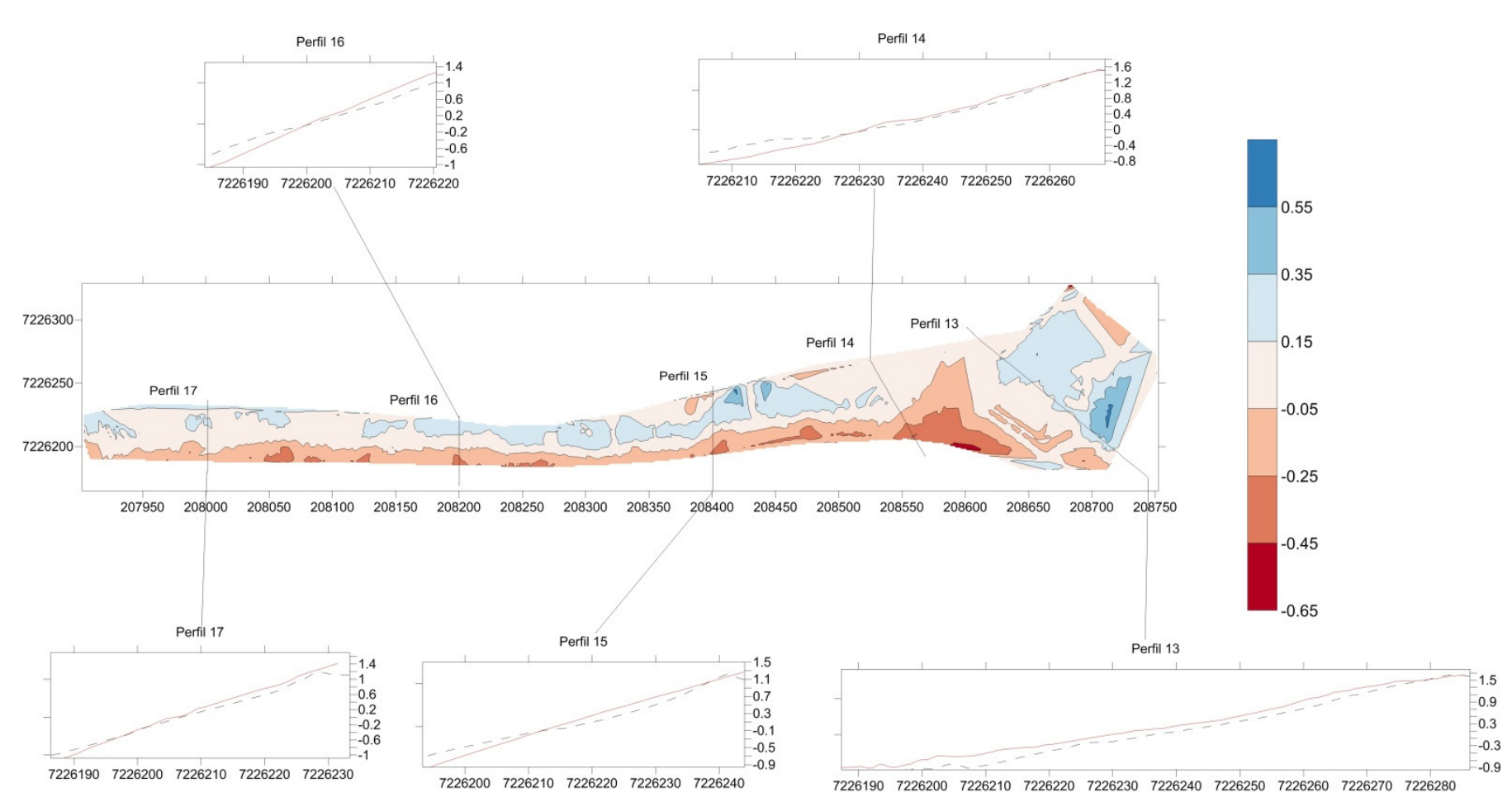

Figura A13: Diferenças altimétricas e comparações de perfis praiais entre os dias 29/01/2012 e 24/02/2012, representados pela linha preta tracejada e linha vermelha cheia respectivamente nos perfis. Os valores expressos em metros.

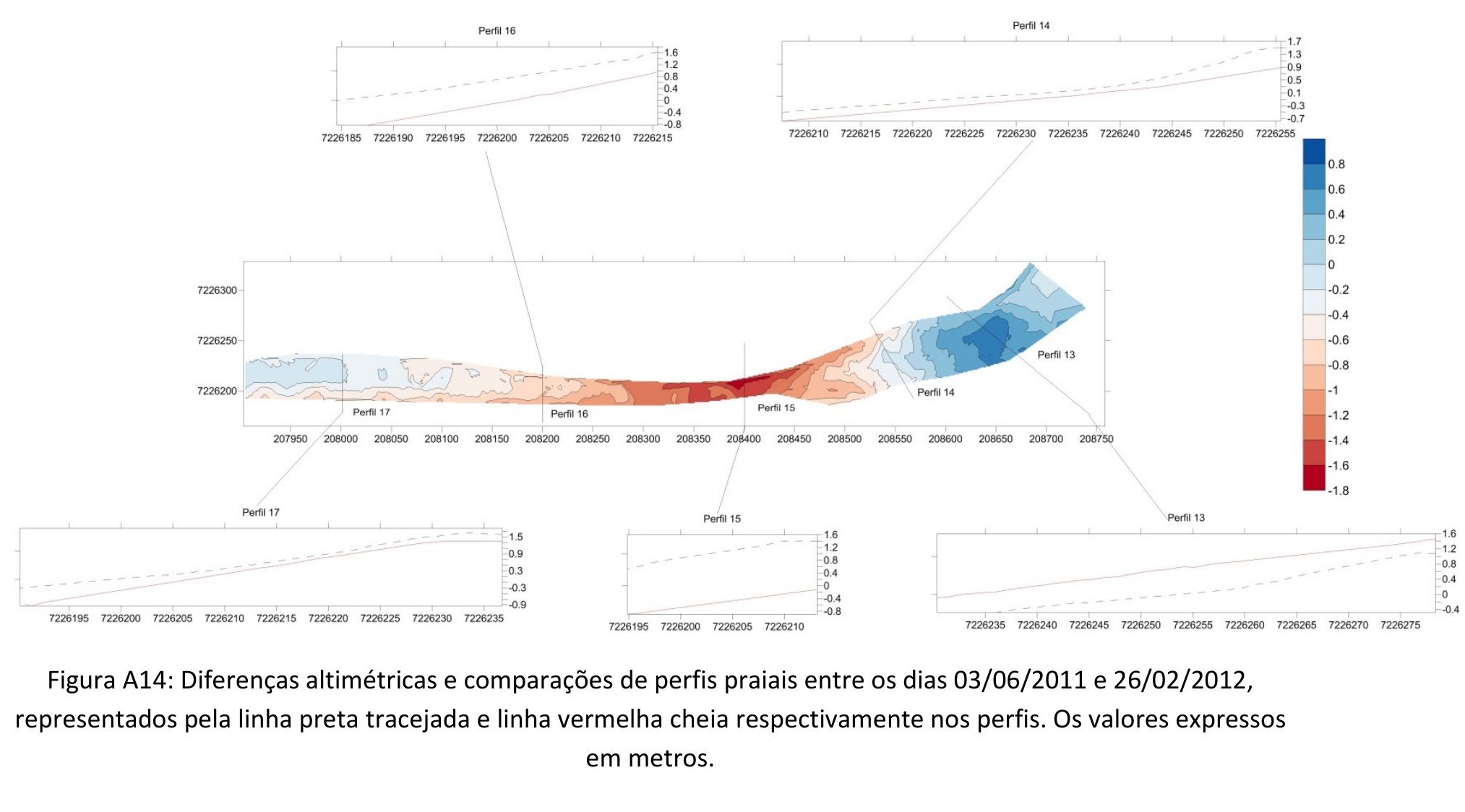




\section{Setor 1}

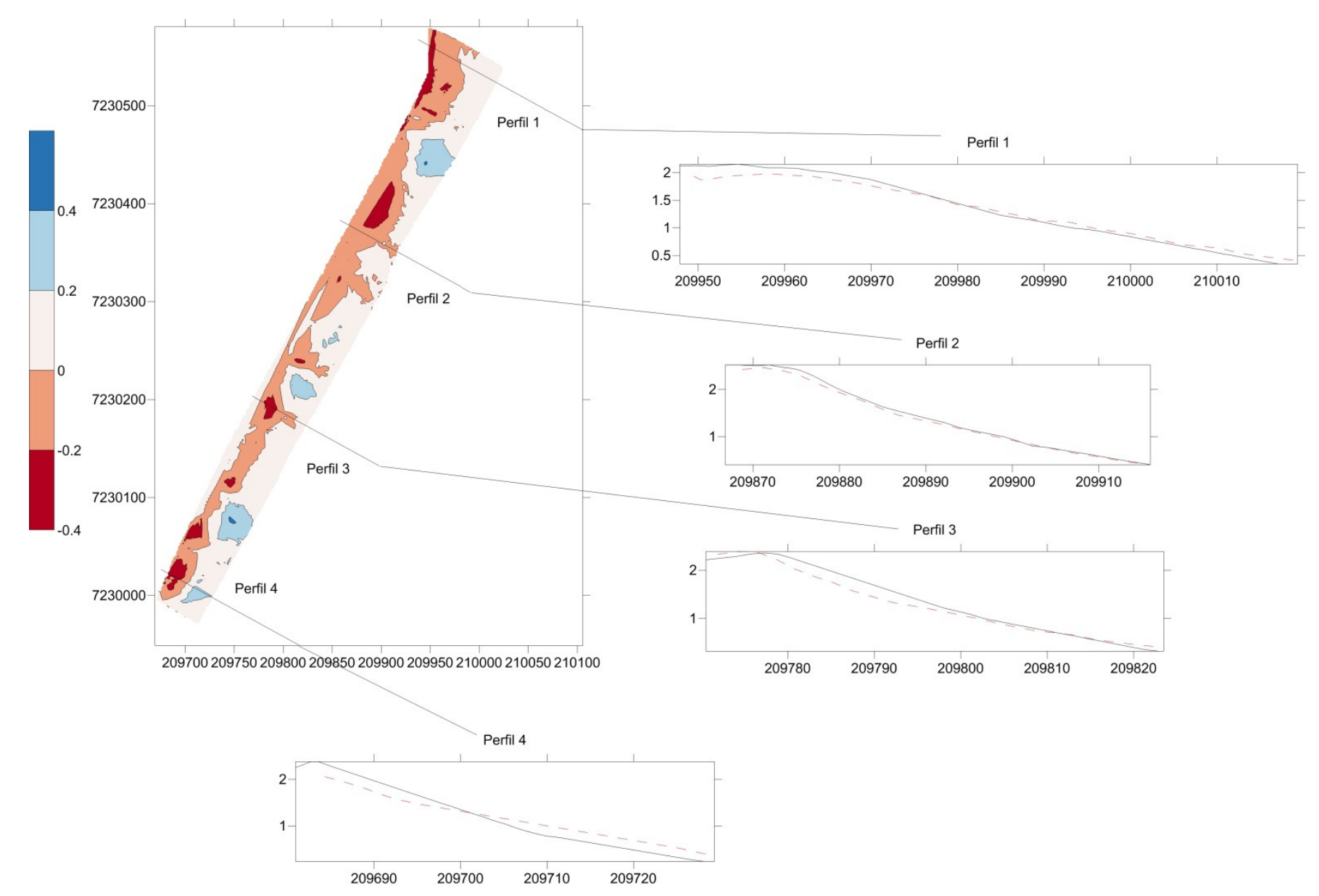

Figura A15: Diferenças altimétricas e comparações de perfis praiais entre os dias 07/06/2011 e 19/07/2011, representados pela linha preta tracejada e linha vermelha cheia respectivamente nos perfis. Os valores expressos em metros.

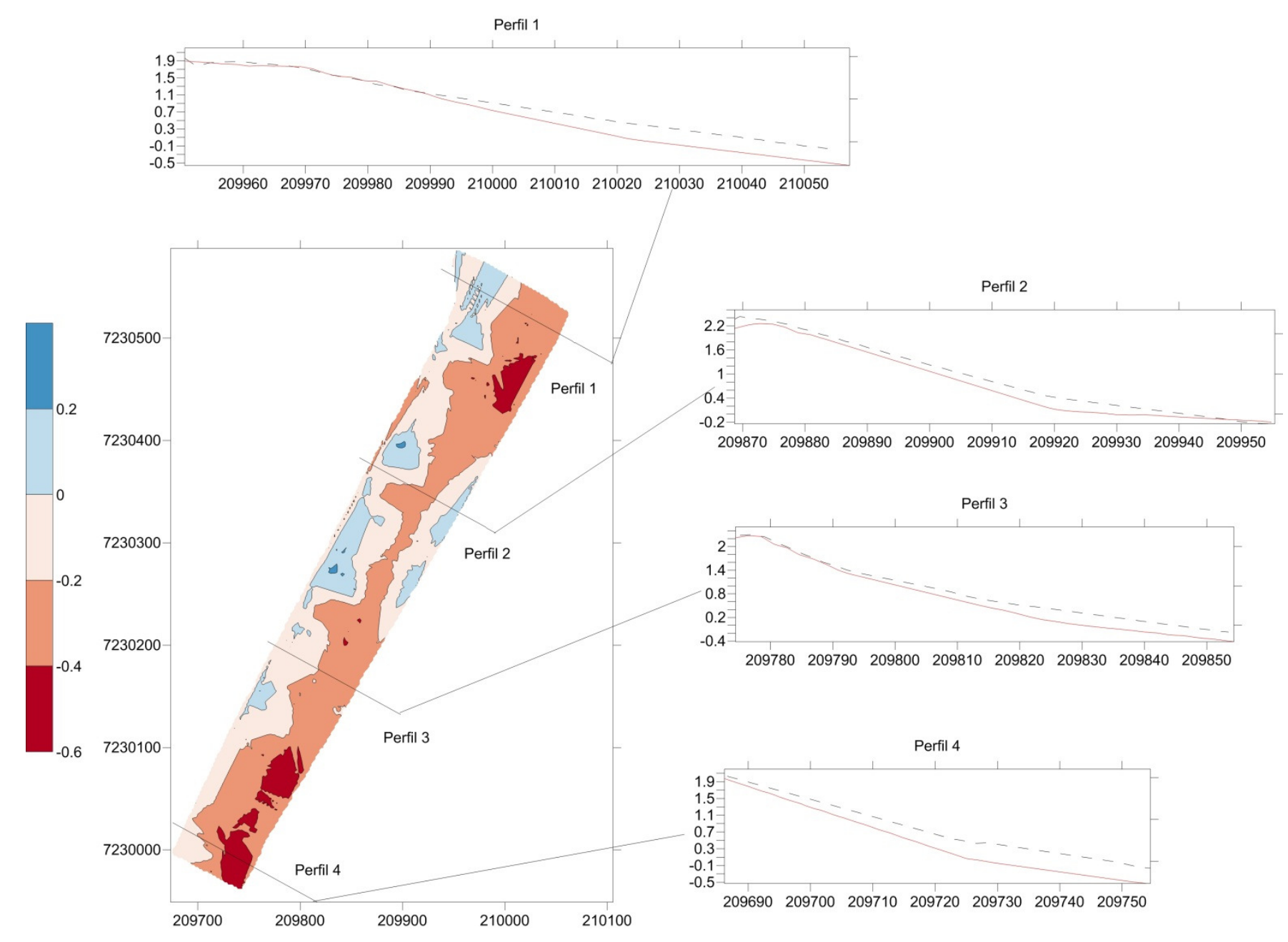

Figura A16 Diferenças altimétricas e comparações de perfis praiais entre os dias 26/07/2011 e 28/09/2011 representados pela linha preta tracejada e linha vermelha cheia respectivamente nos perfis. Os valores expressos

em metros. 

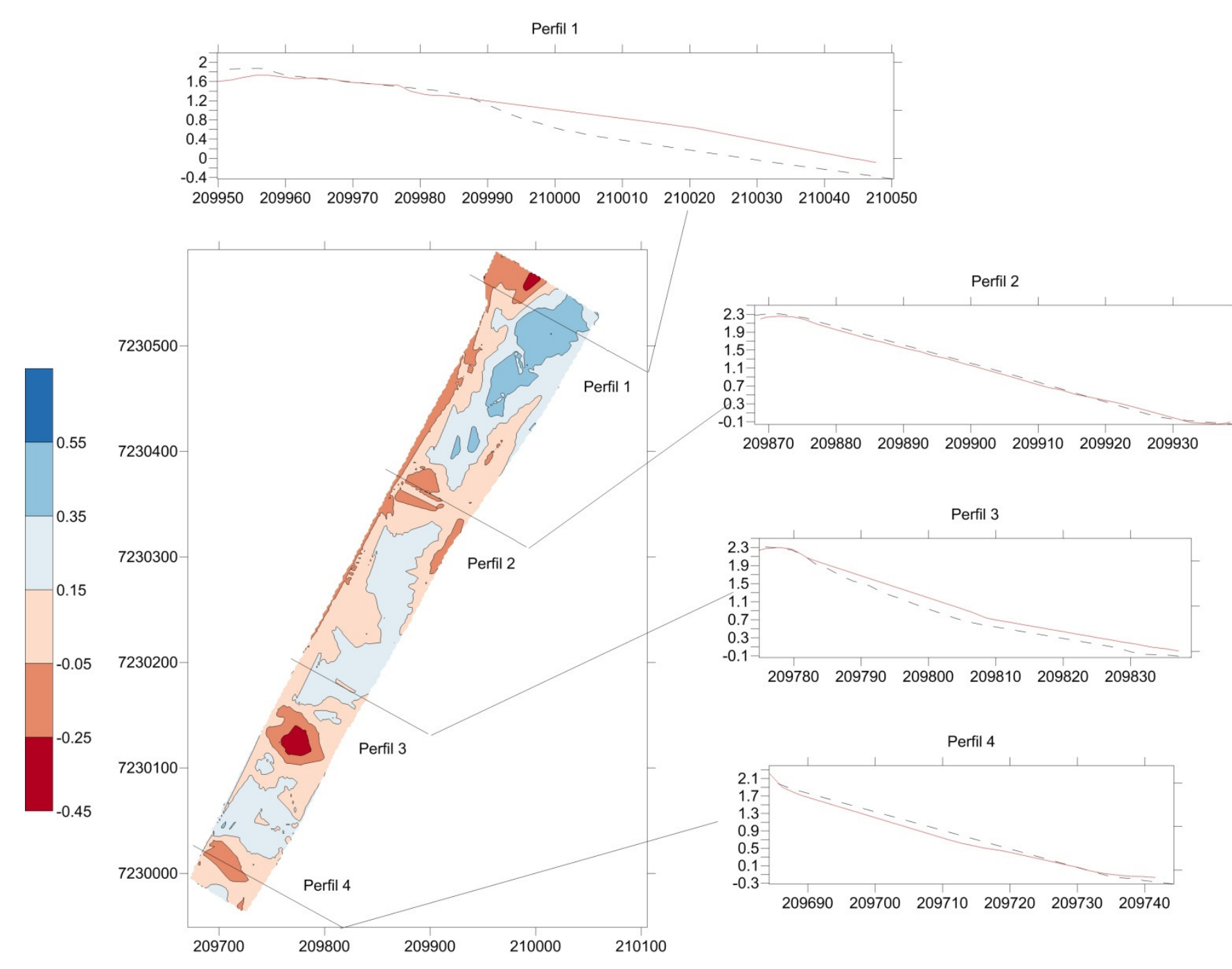

209870209880209890209900209910209920209930

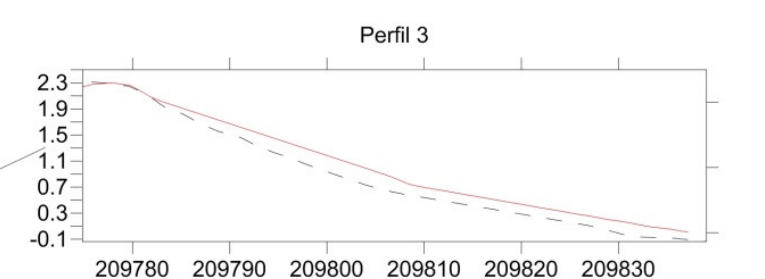

209780209790209800209810209820209830

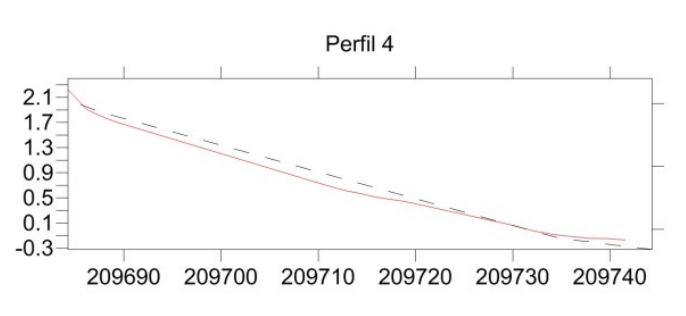

Figura A17: Diferenças altimétricas e comparações de perfis praiais entre os dias 29/09/2011 e 21/11/2011, representados pela linha preta tracejada e linha vermelha cheia respectivamente nos perfis. Os valores expressos em metros.

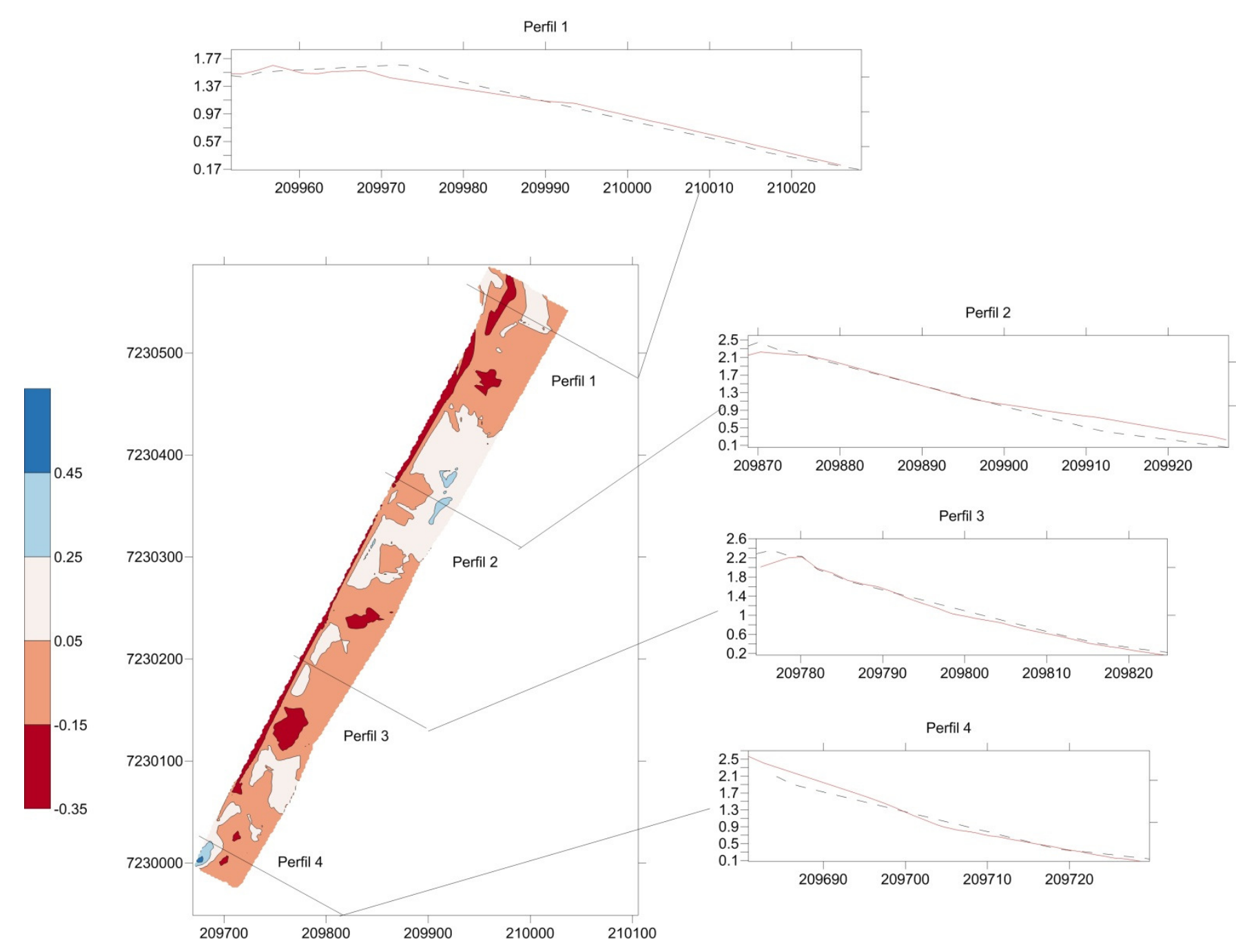

Figura A18: Diferenças altimétricas e comparações de perfis praiais entre os dias 24/11/2011 e 13/12/2011, representados pela linha preta tracejada e linha vermelha cheia respectivamente nos perfis. Os valores expressos em metros. 

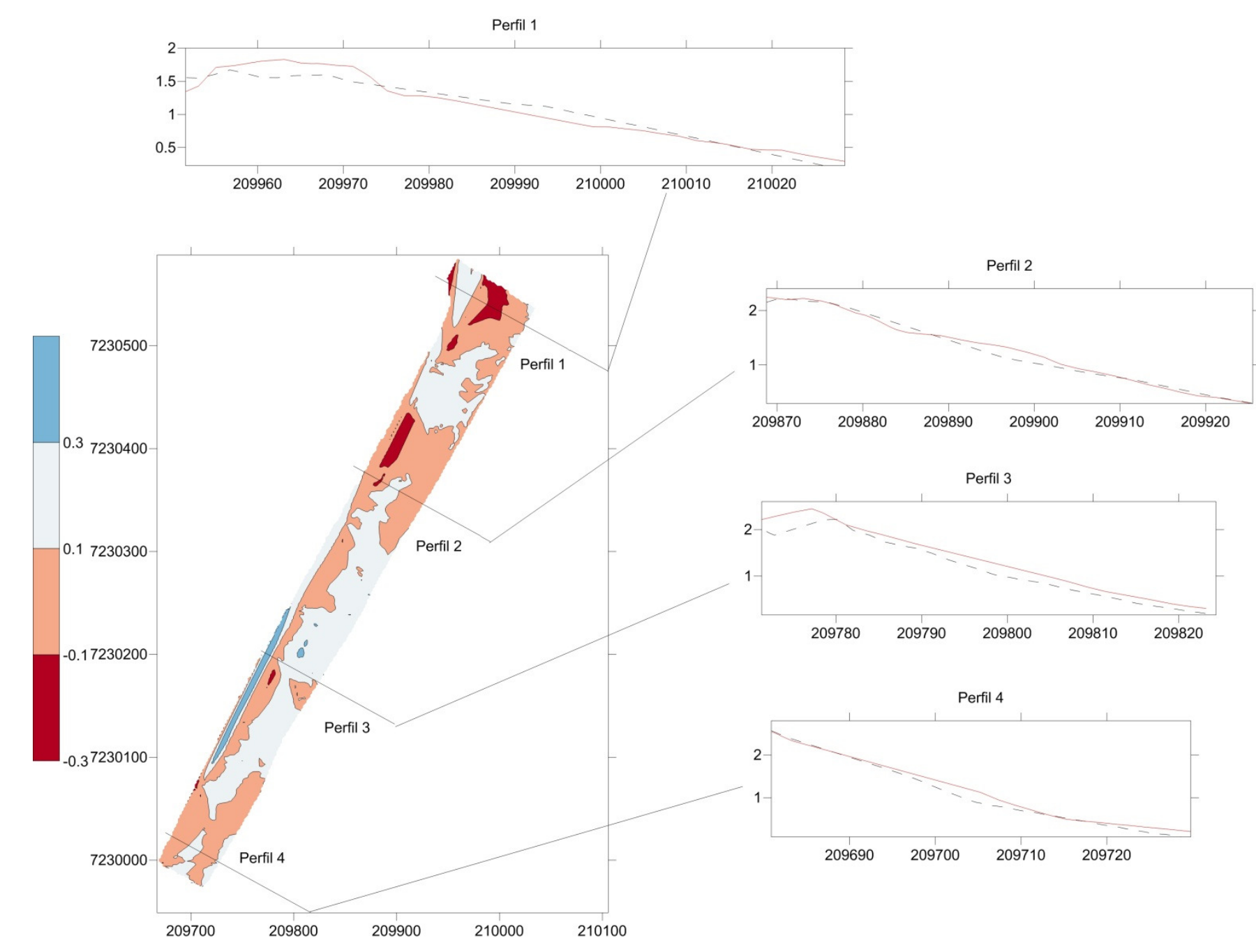

Figura A19: Diferenças altimétricas e comparações de perfis praiais entre os dias 13/12/2011 e 28/01/2012 representados pela linha preta tracejada e linha vermelha cheia respectivamente nos perfis. Os valores expressos em metros.

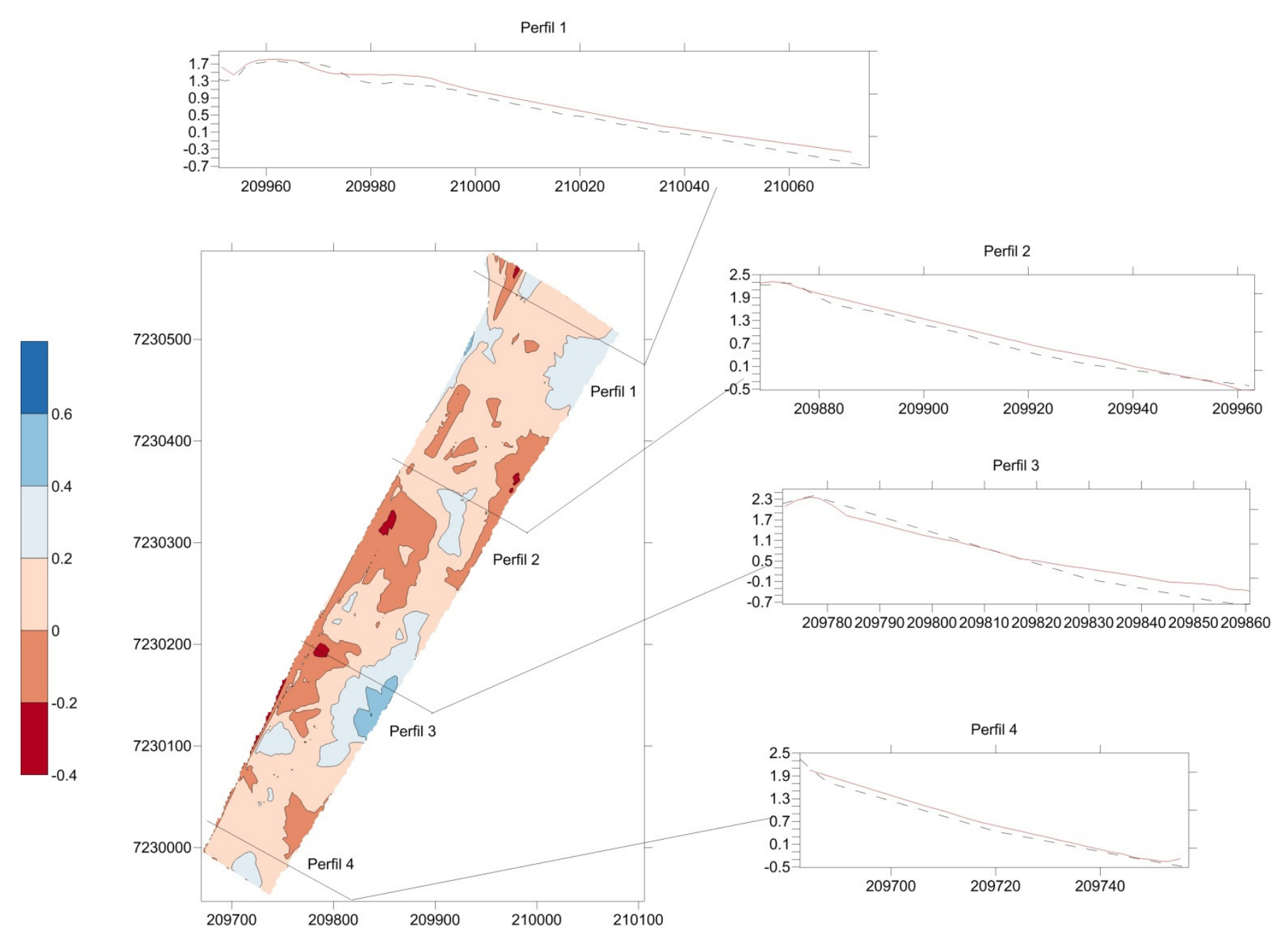

Figura A20: Diferenças altimétricas e comparações de perfis praiais entre os dias 29/01/2012 e 24/02/2012 representados pela linha preta tracejada e linha vermelha cheia respectivamente nos perfis. Os valores expressos em metros. 


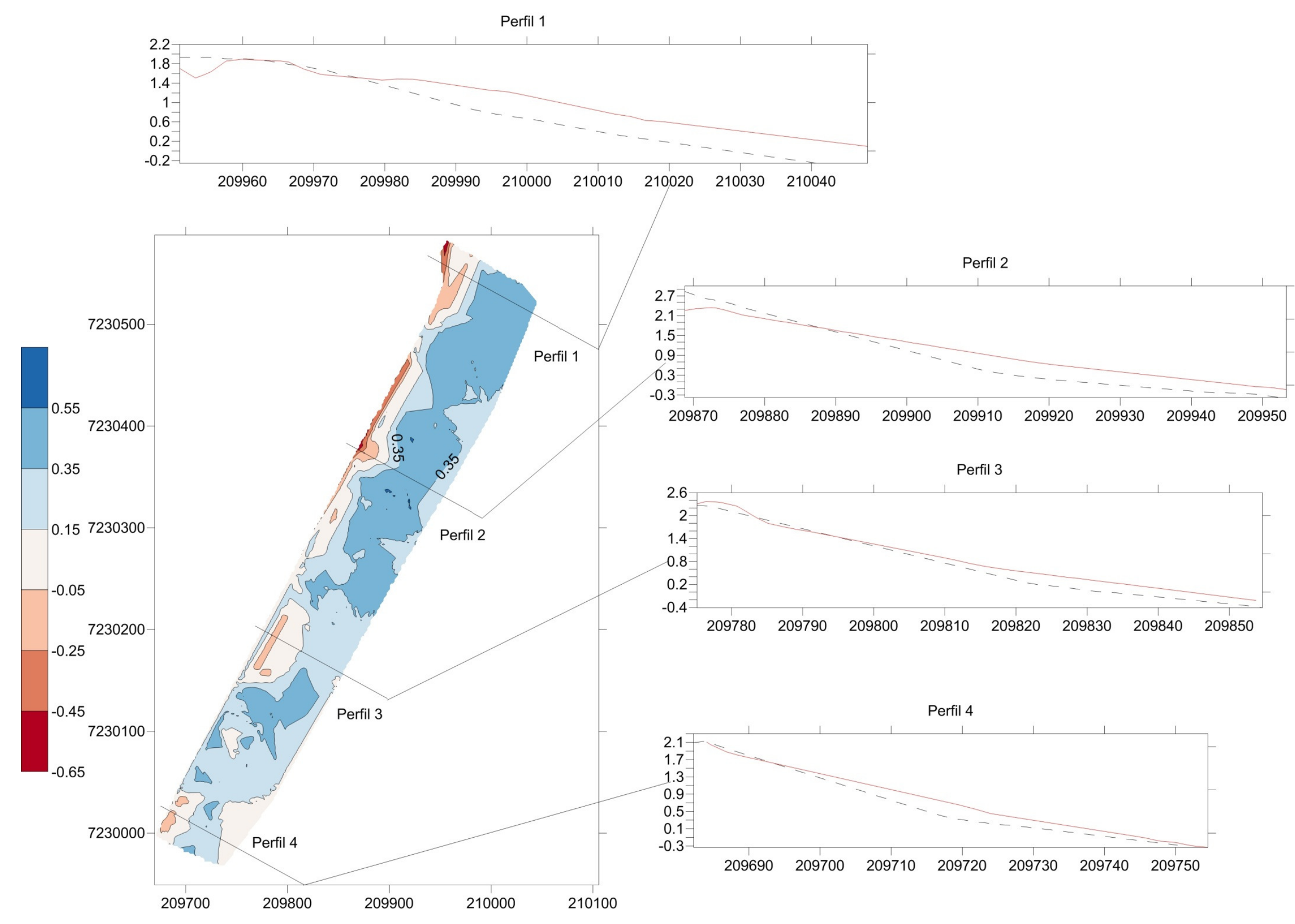

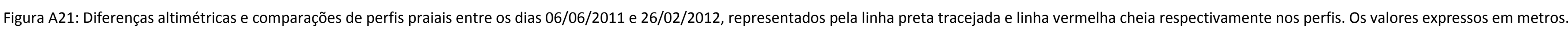


Escala Diária: Setor 2 -Área Leste

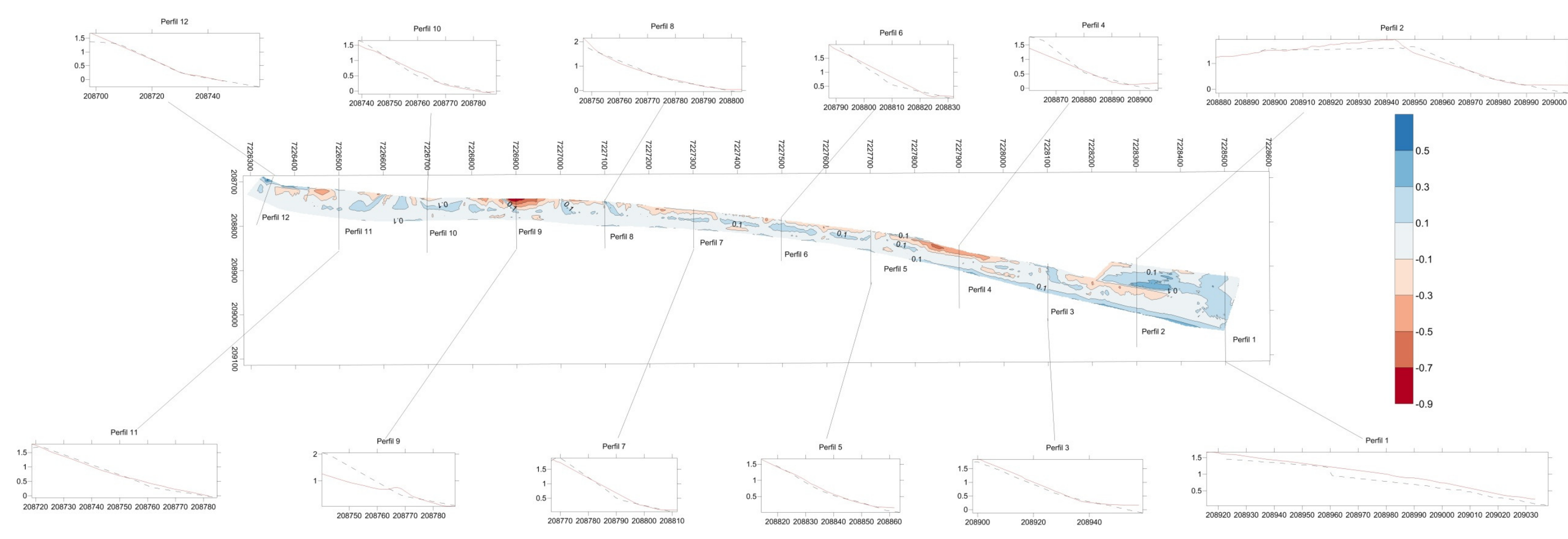

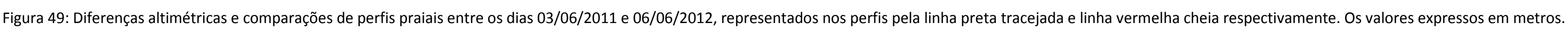

Escala Diária: Setor 2 - Área Sul

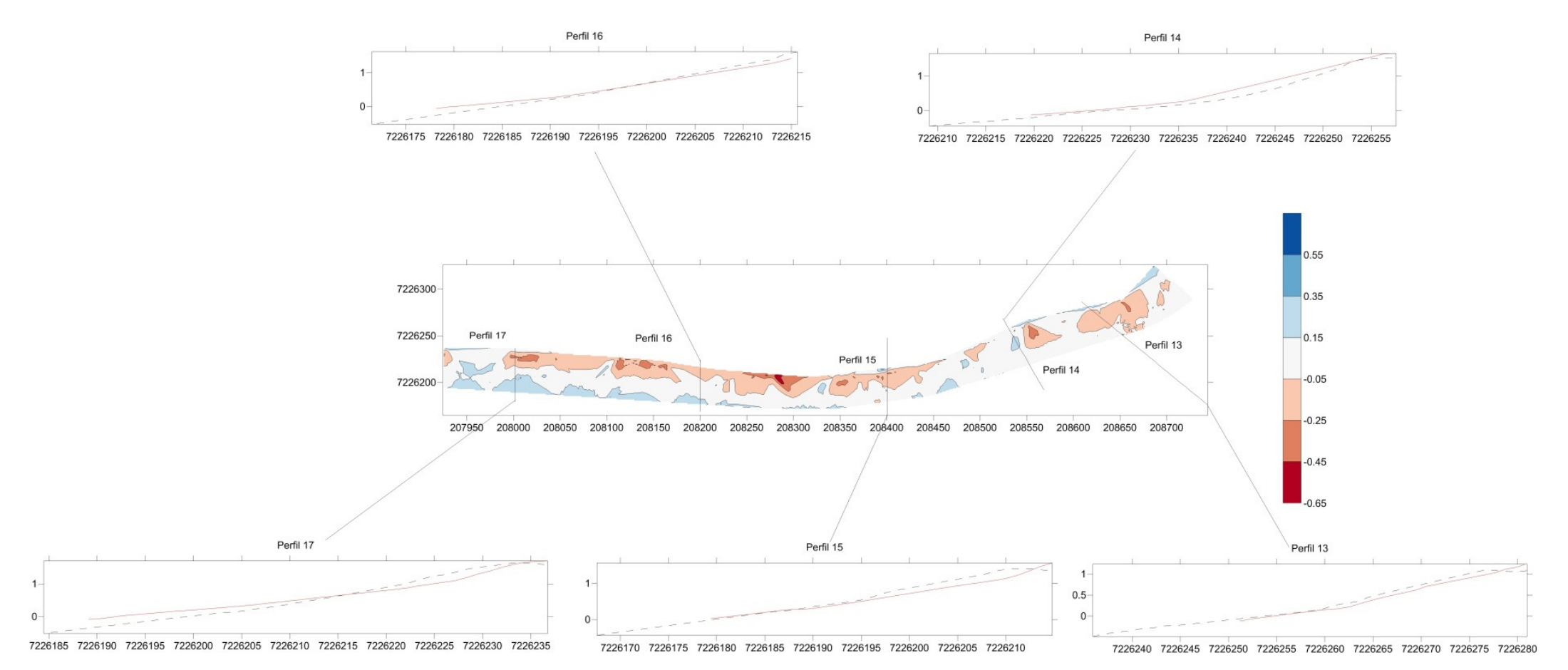

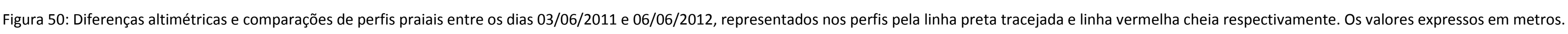




\section{Anexo II}

Neste anexo se encontram os gráficos produzidos com os resultados das simulações numéricas. As figuras são compostas por vetores de direção de onda sobrepostos a um campo de intensidade de altura de onda. 


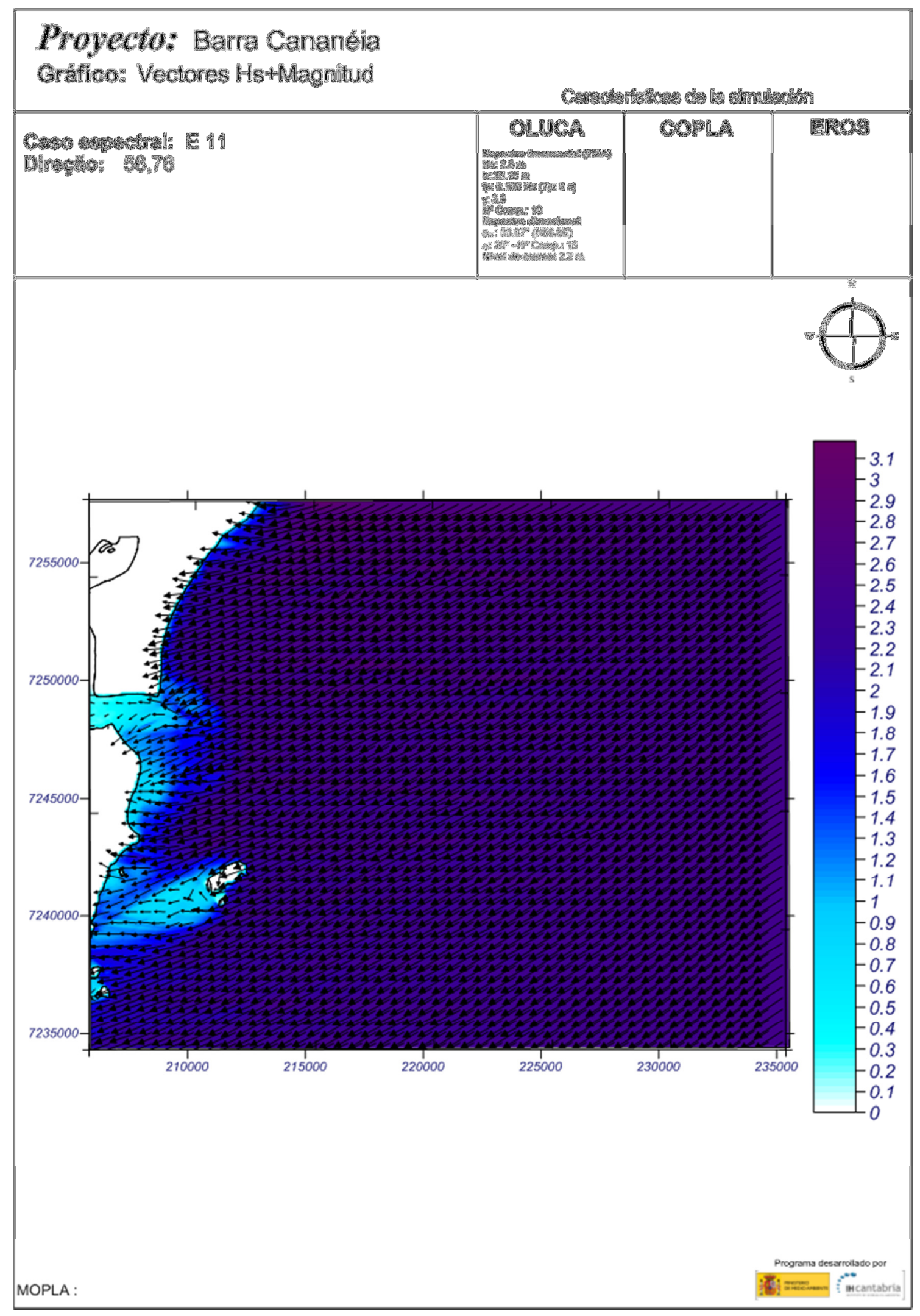

Figura B1: Resultados da propagação do Caso E11. 


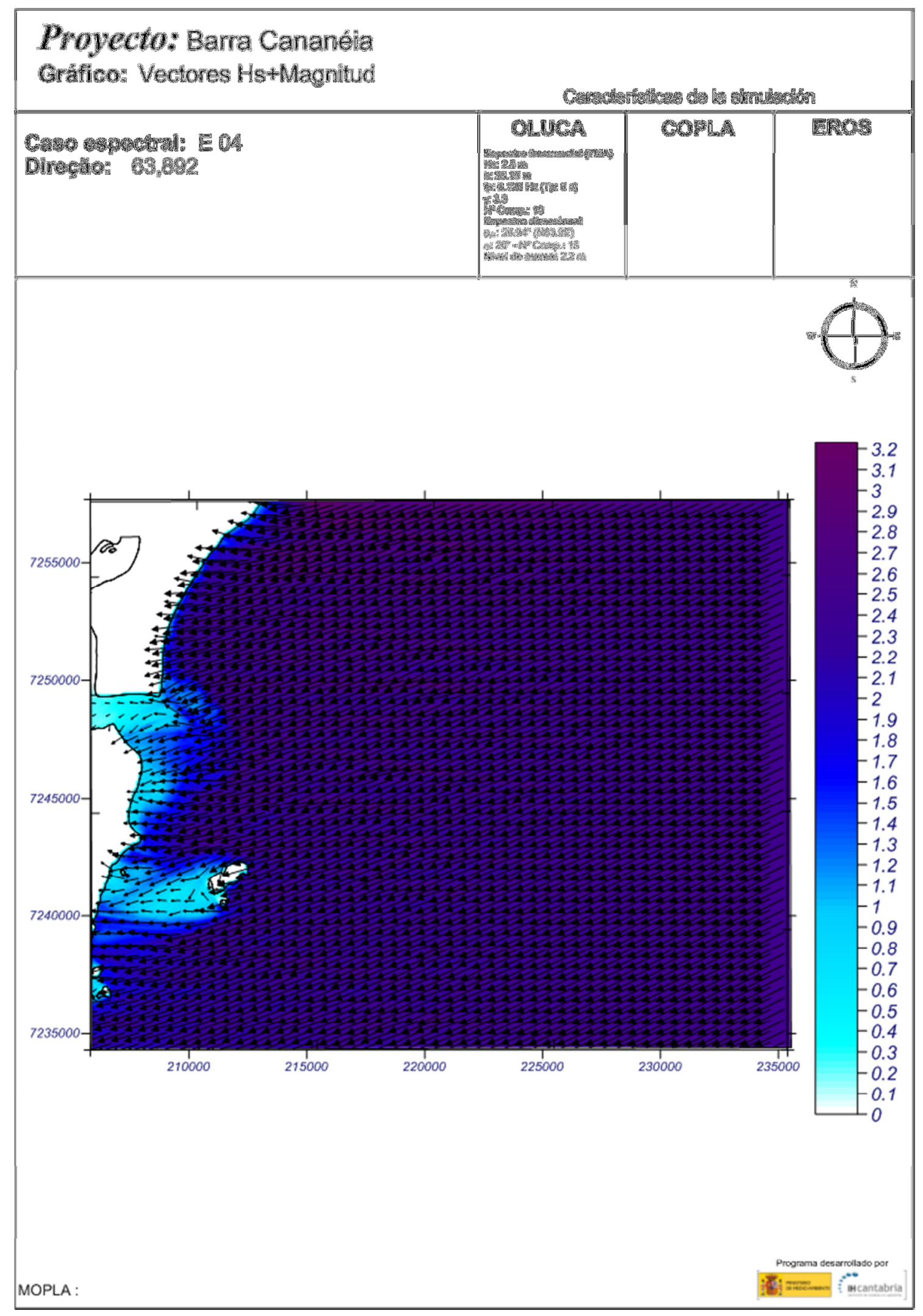

Figura B2: Resultados da propagação do Caso E 04. 


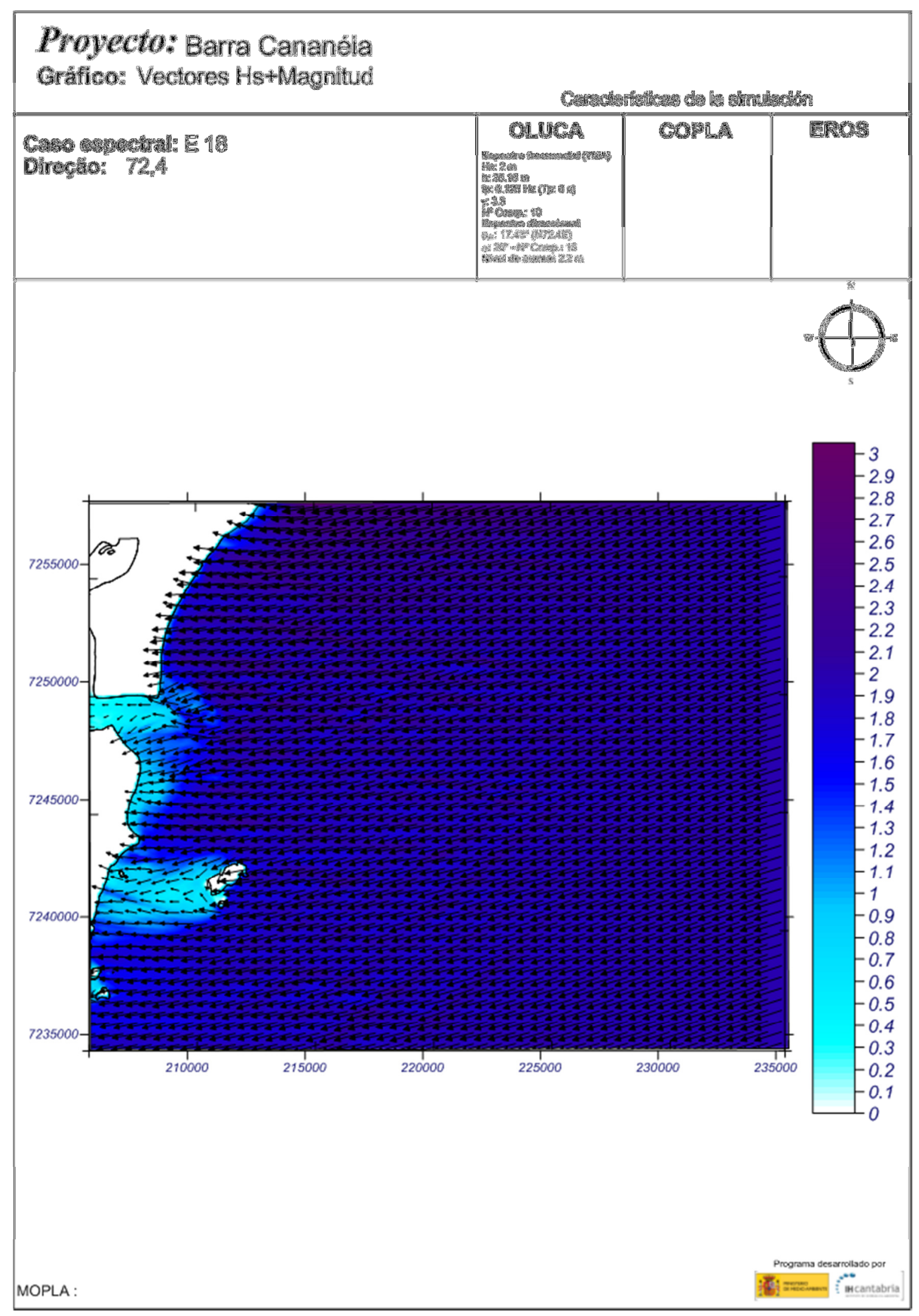

Figura B3: Resultados da propagação do Caso E 18. 


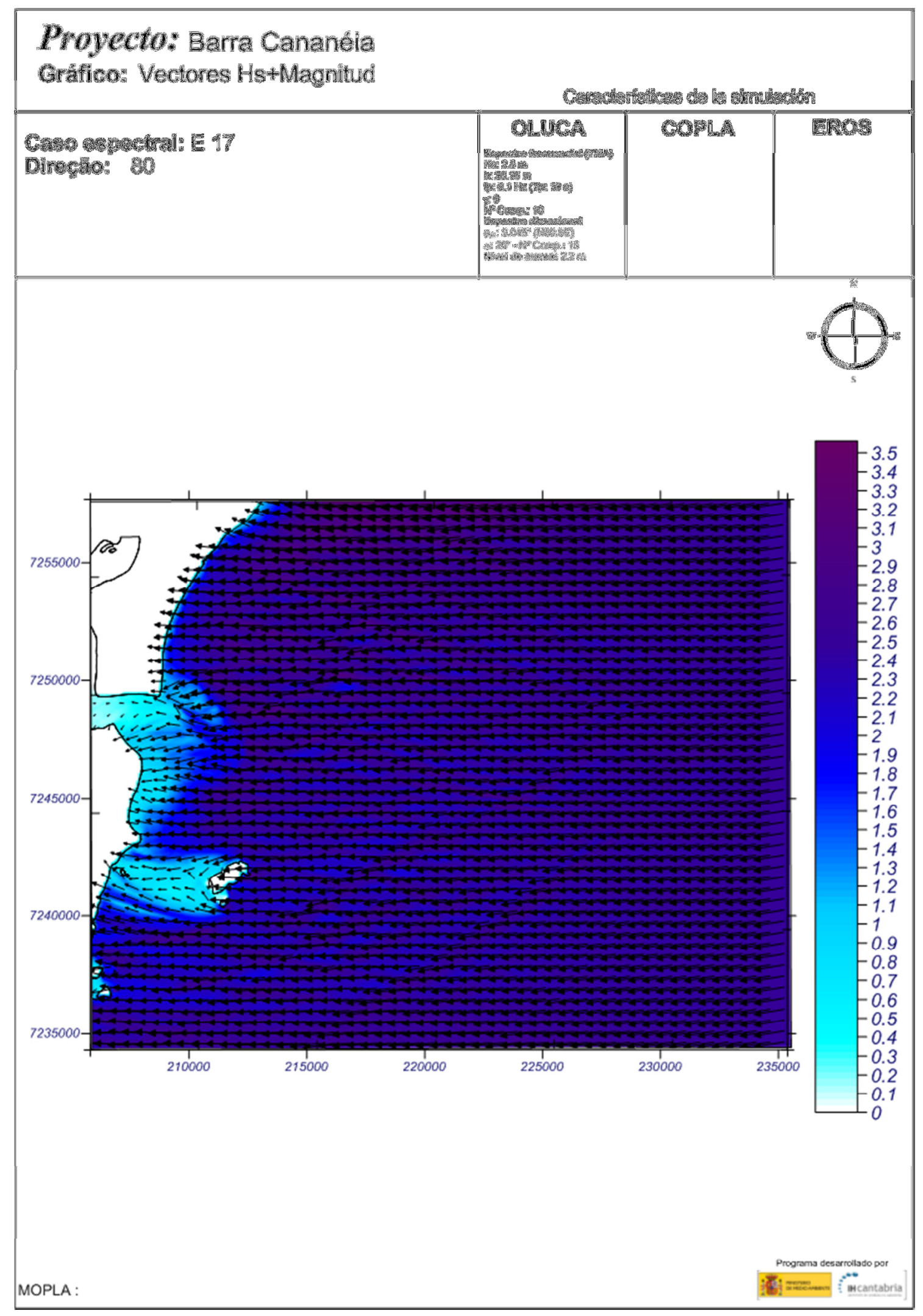

Figura B4: Resultados da propagação do Caso E 17. 


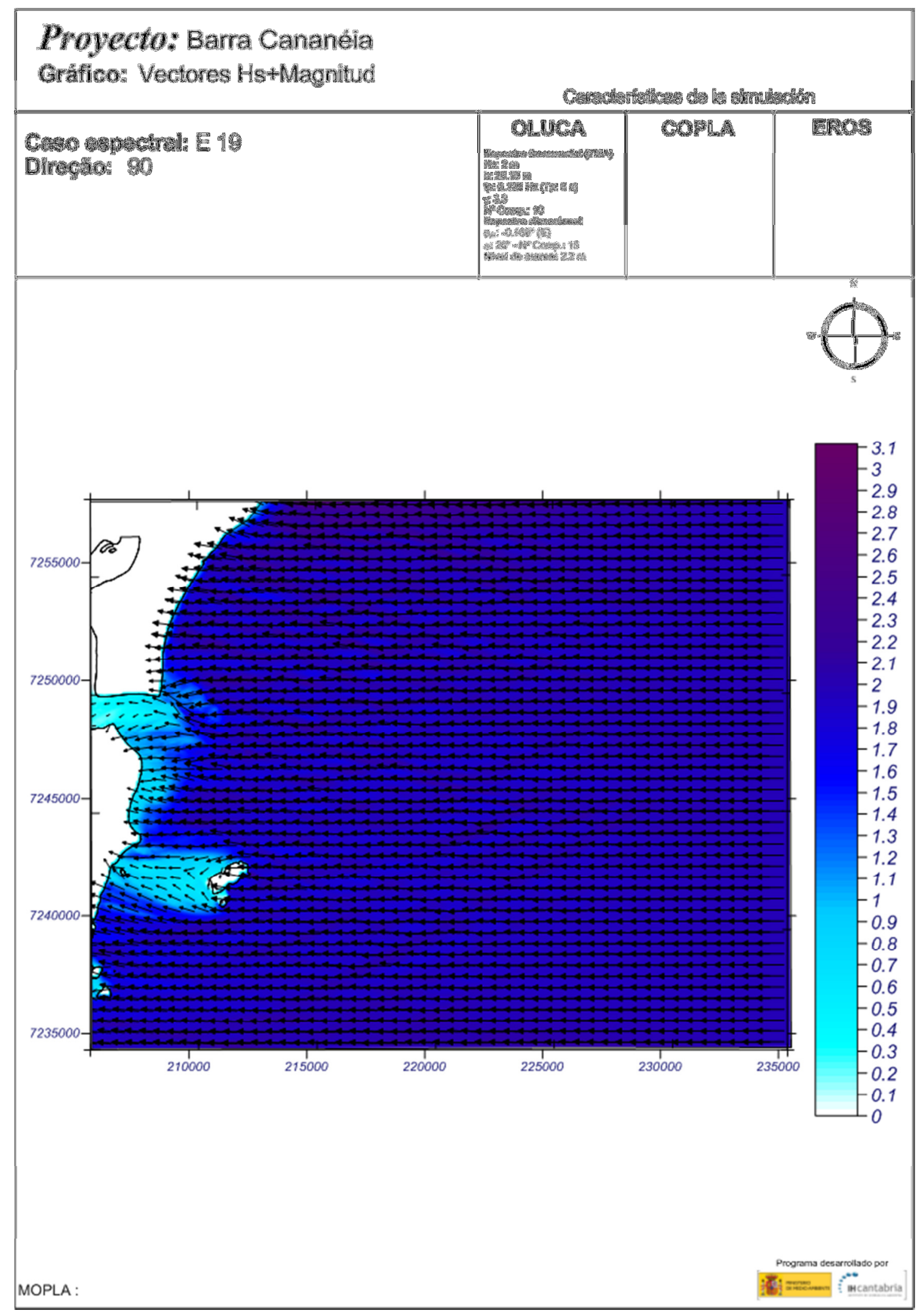

Figura B5: Resultados da propagação do Caso E 19. 


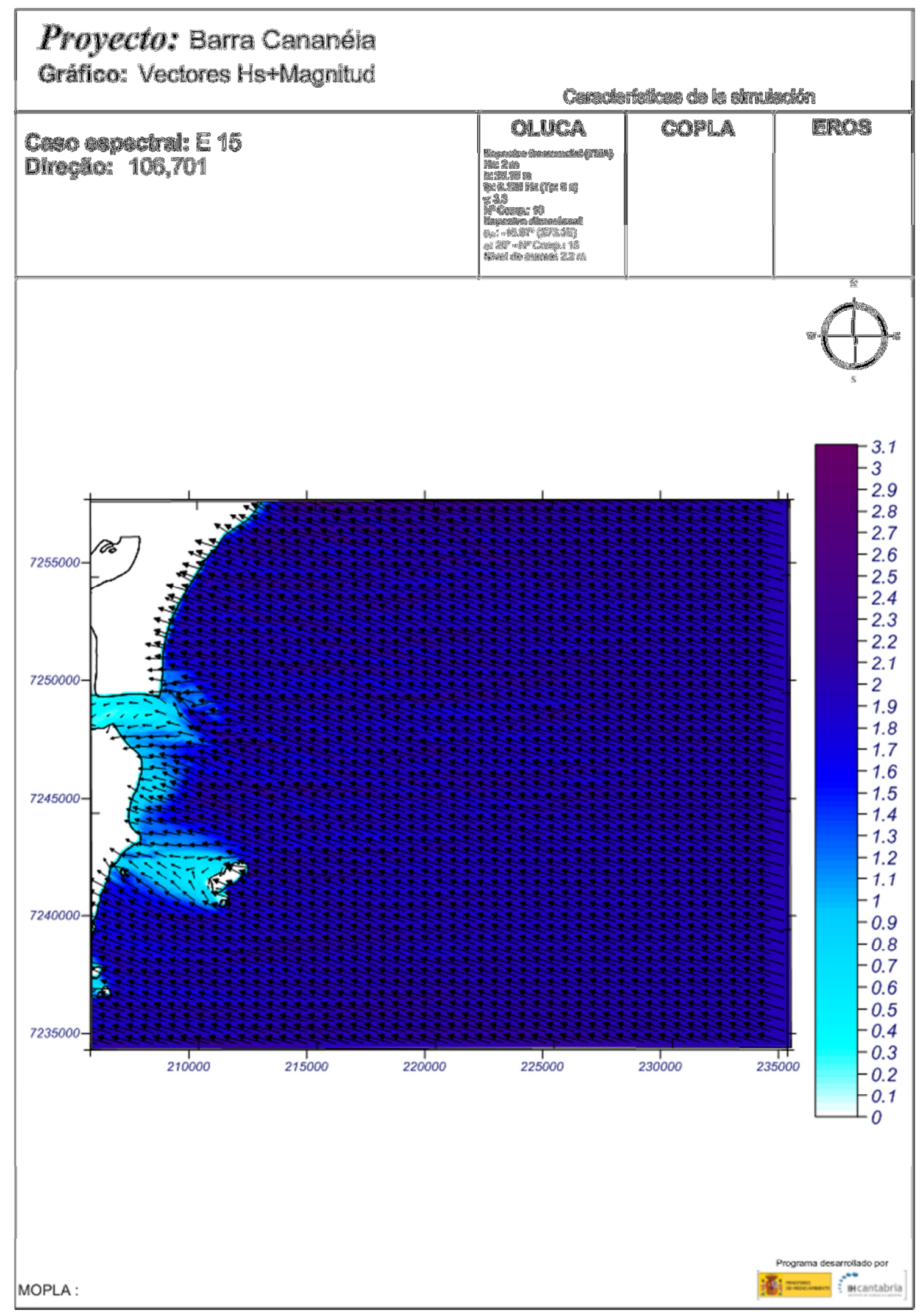

Figura B6: Resultados da propagação do Caso E 15. 


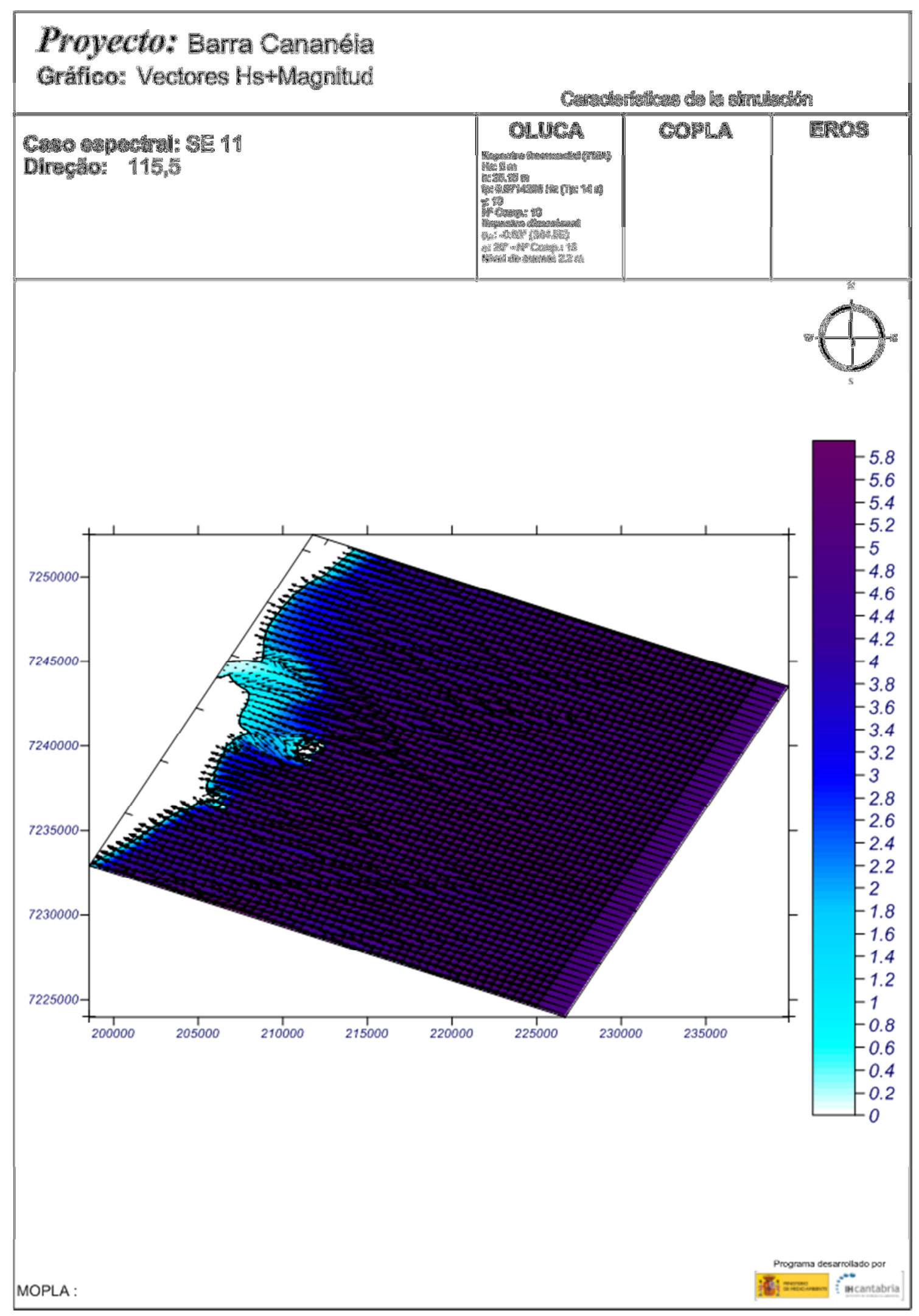

Figura B7: Resultados da propagação do Caso E 11. 


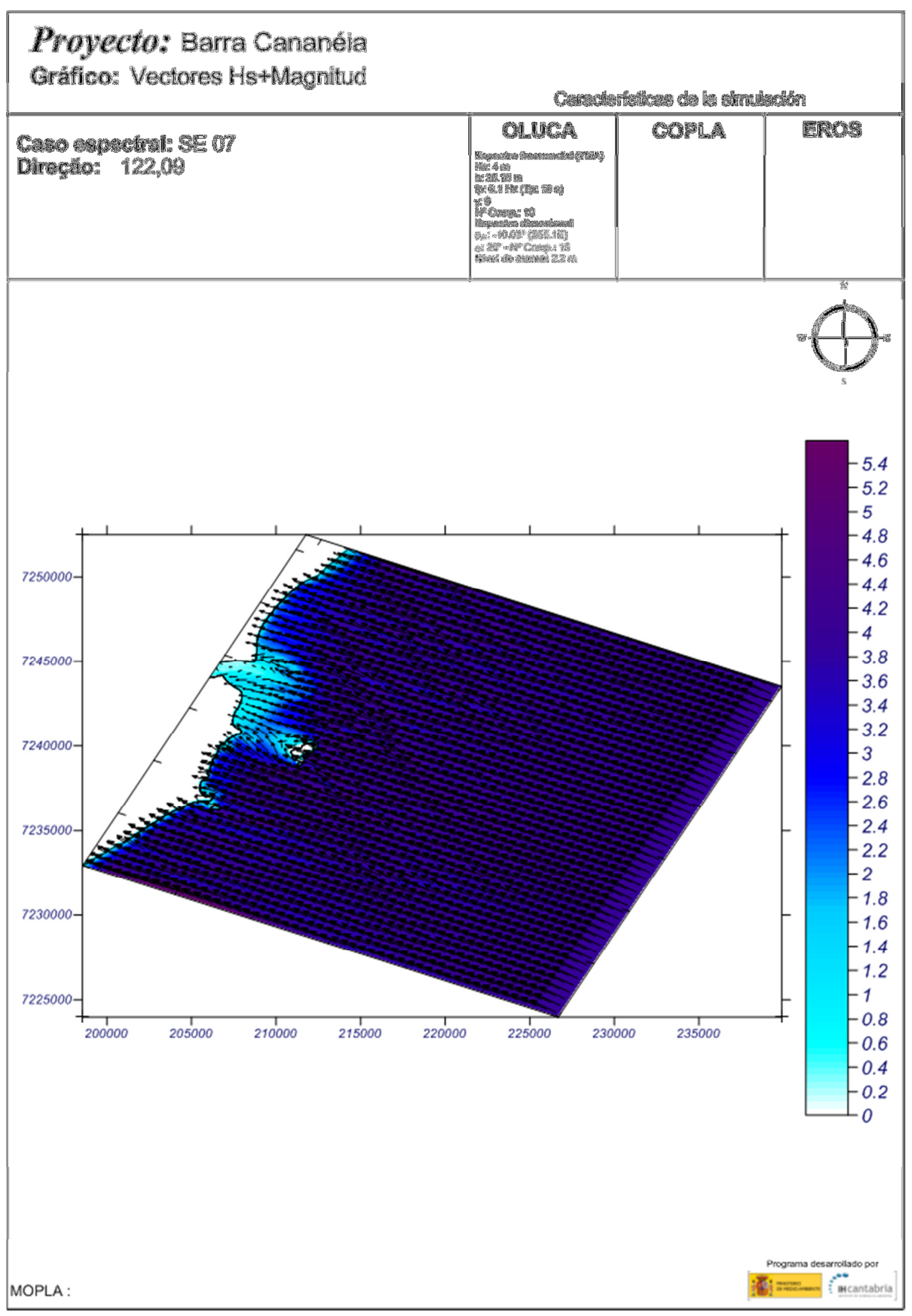

Figura B8: Resultados da propagação do Caso SE 07. 


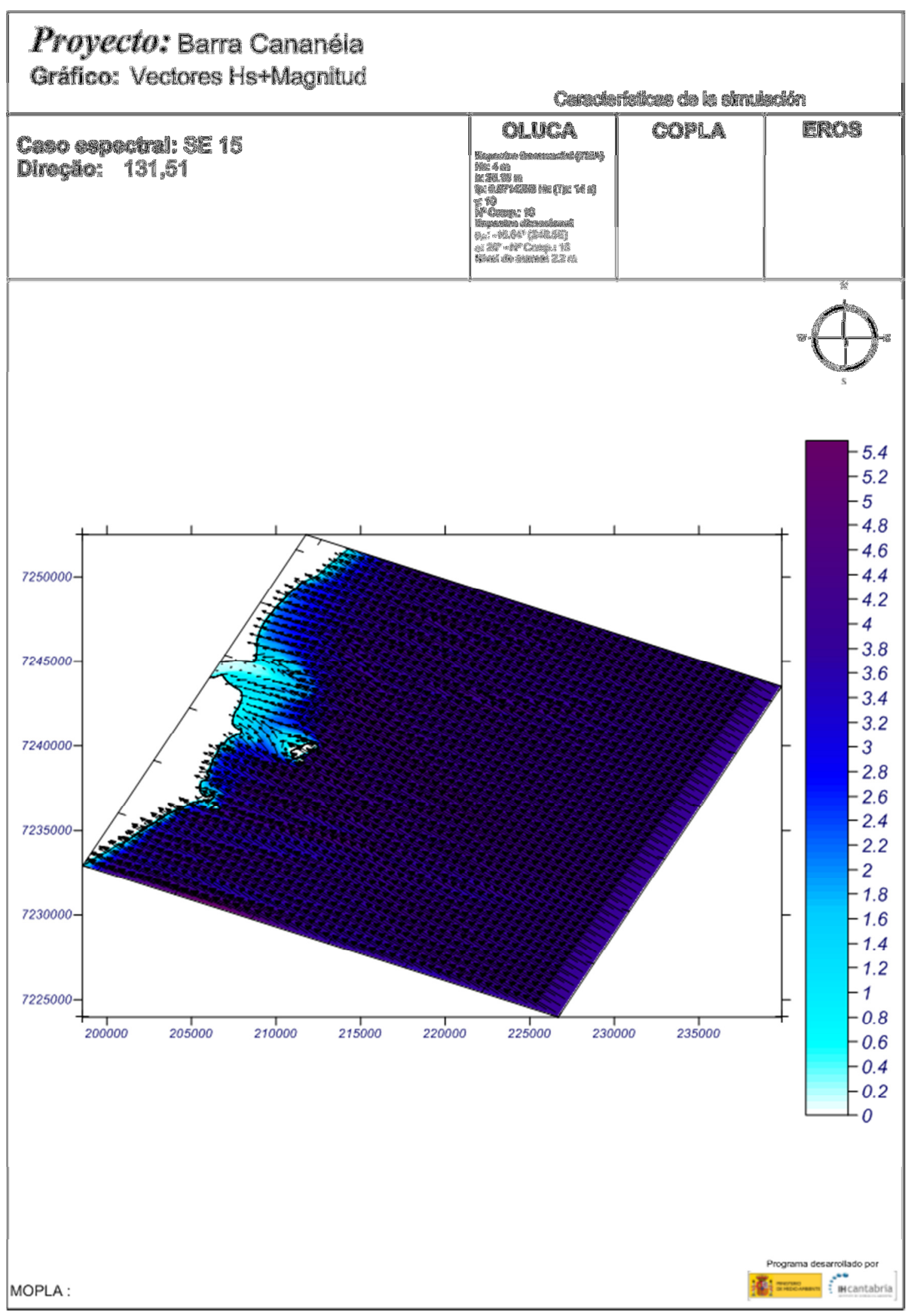

Figura B9: Resultados da propagação do Caso SE 15. 


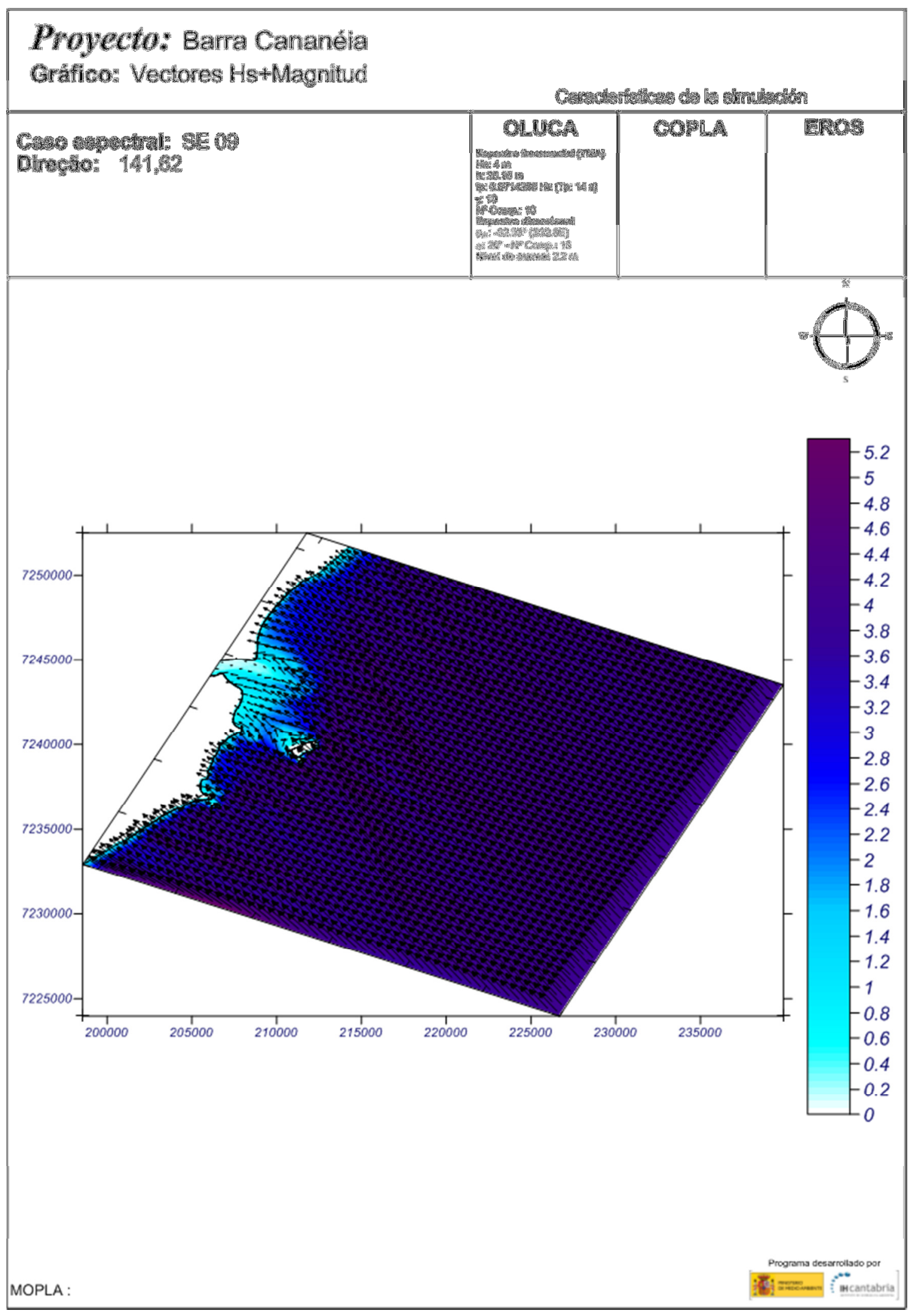

Figura B10: Resultados da propagação do Caso SE 09. 


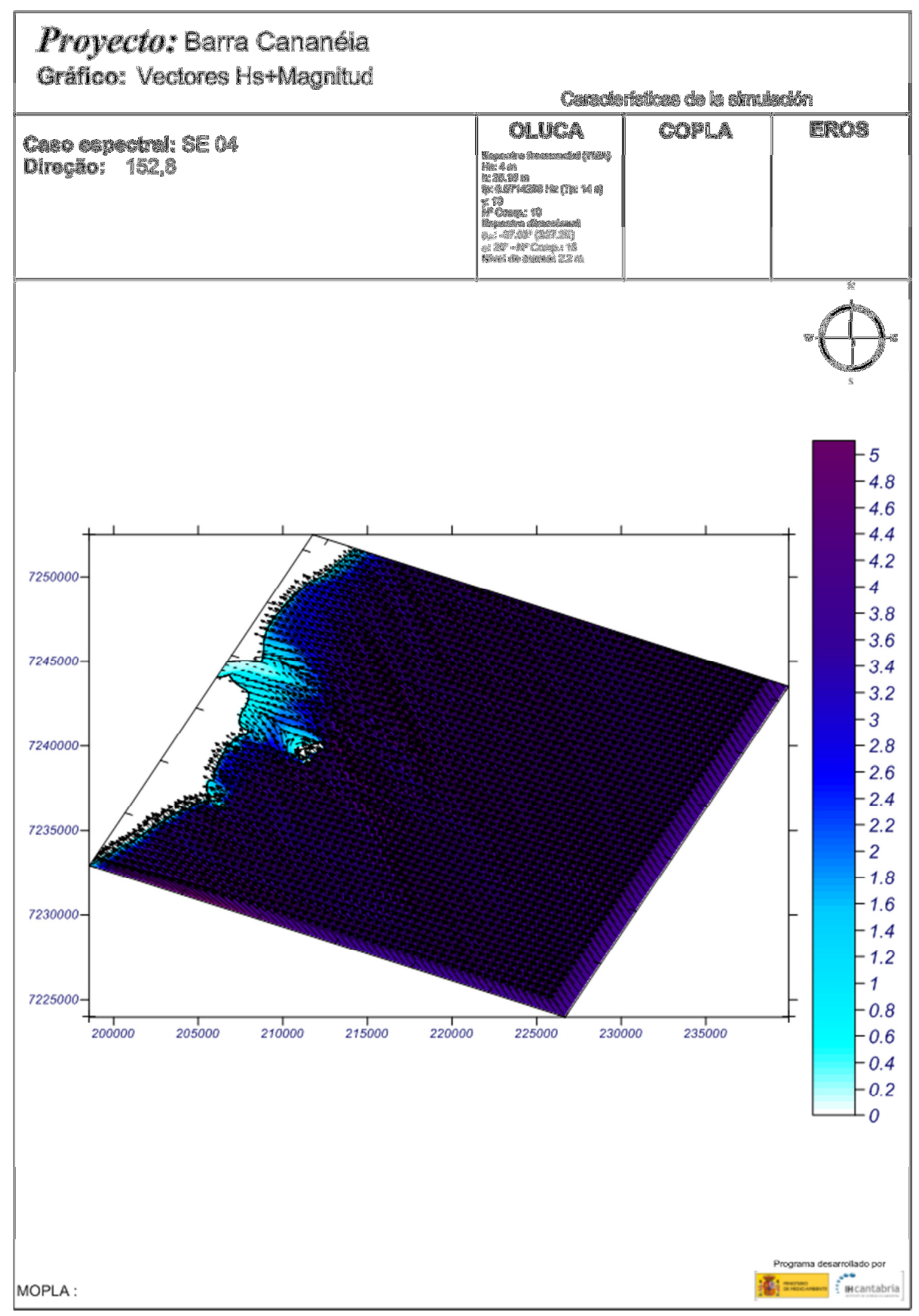

Figura B11: Resultados da propagação do Caso SE 04. 


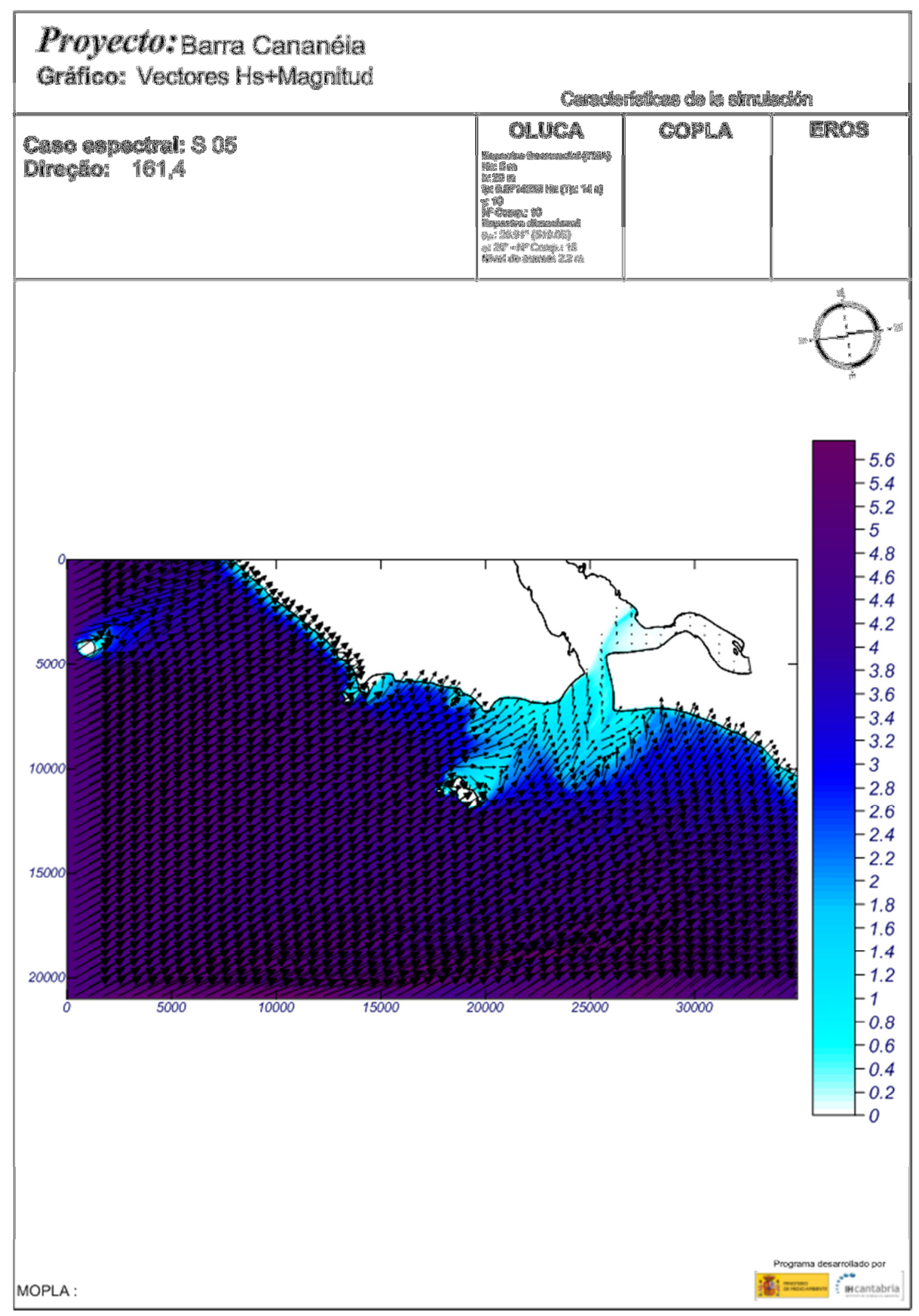

Figura B12: Resultados da propagação do Caso SE 05. 


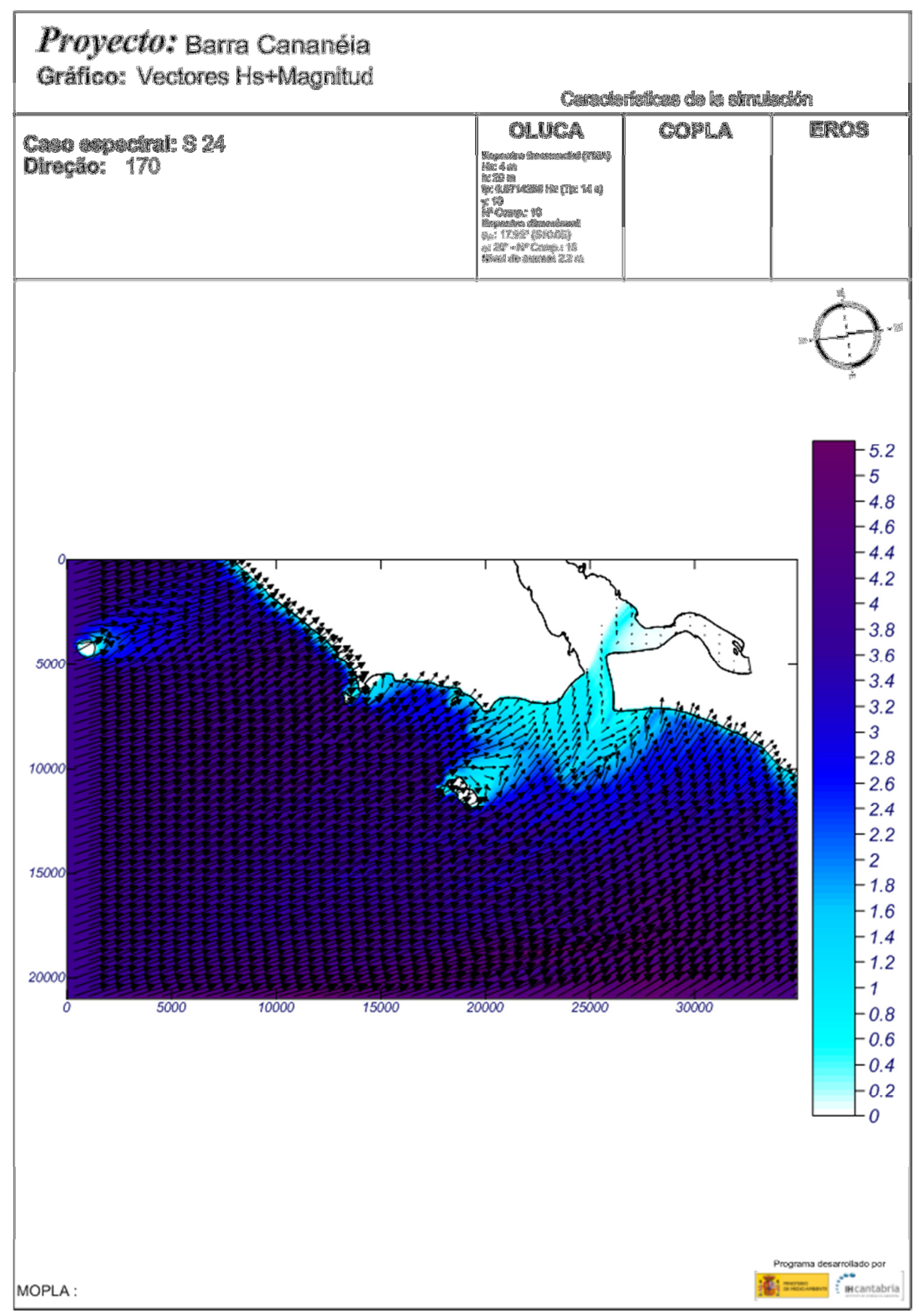

Figura B13: Resultados da propagação do Caso SE 24. 


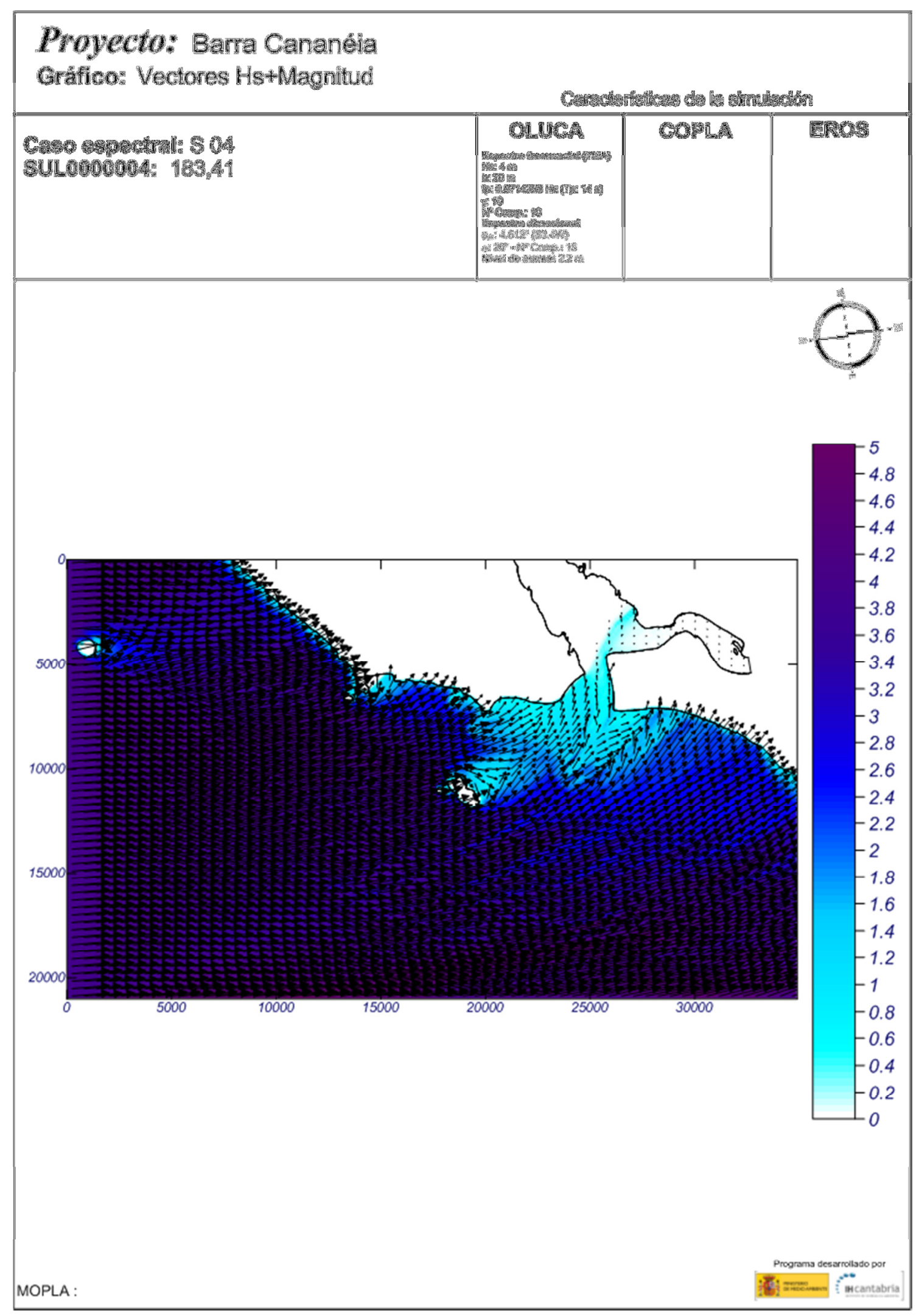

Figura B14: Resultados da propagação do Caso S 04. 


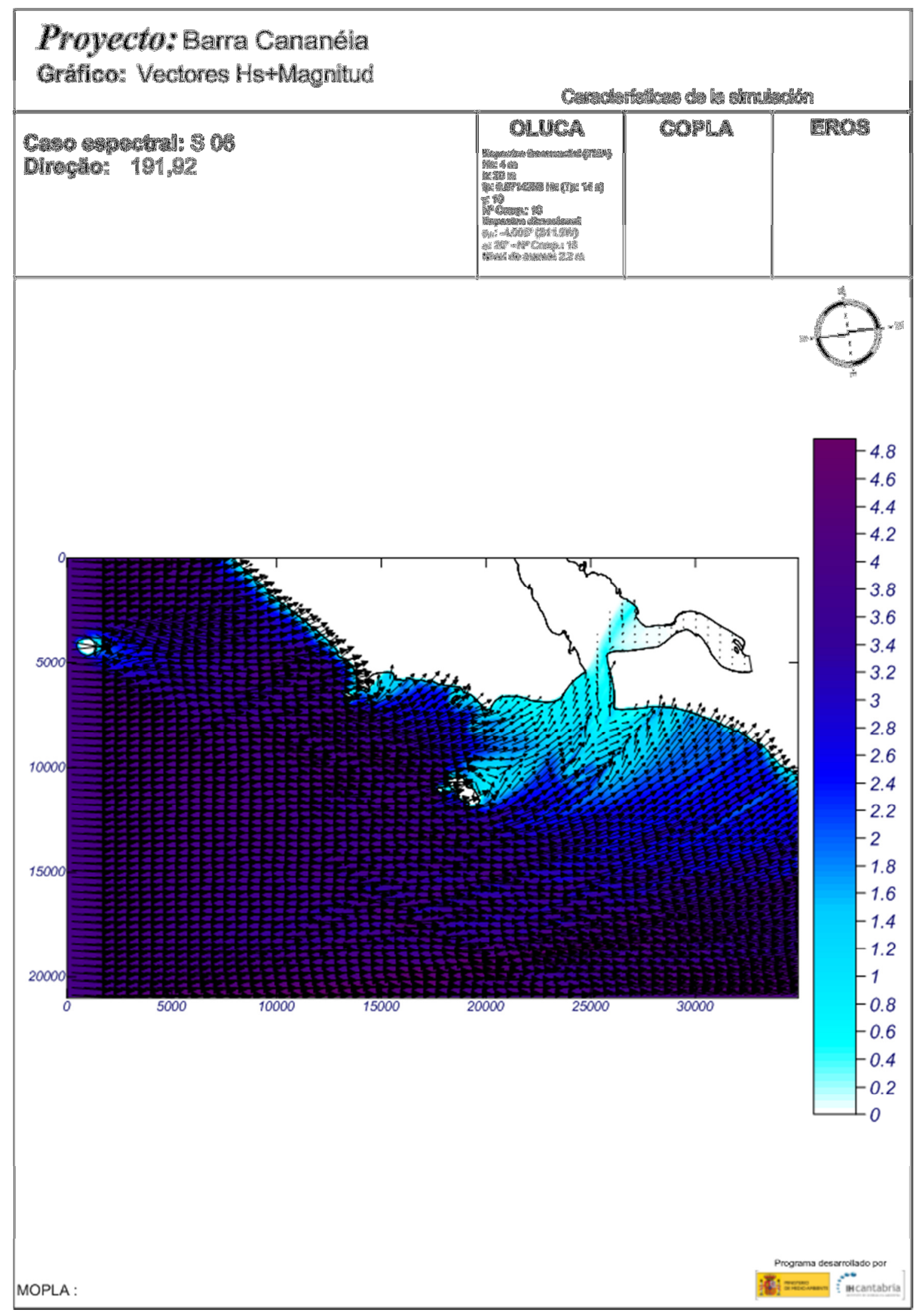

Figura B15: Resultados da propagação do Caso S 06. 


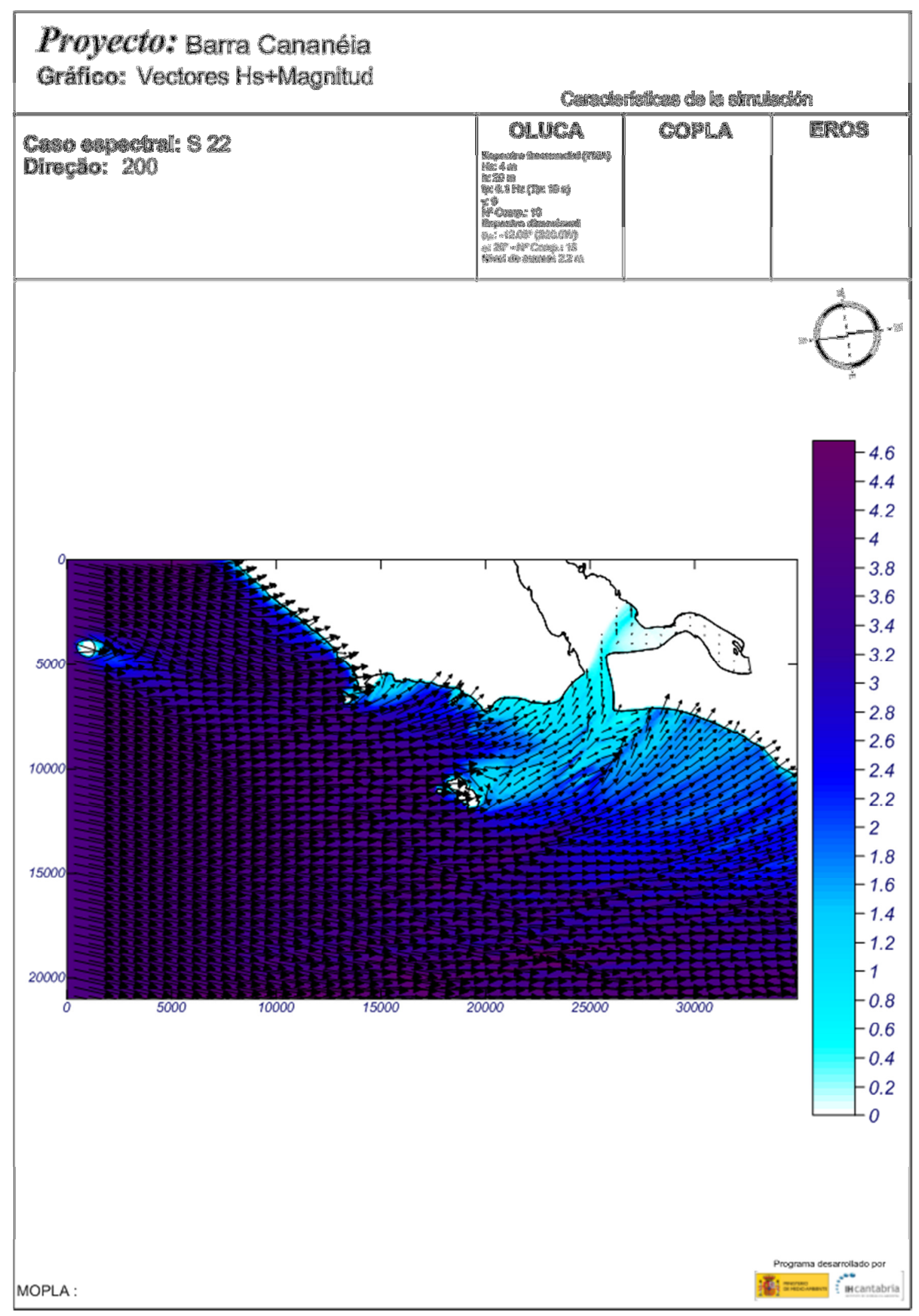

Figura B16: Resultados da propagação do Caso S 22. 


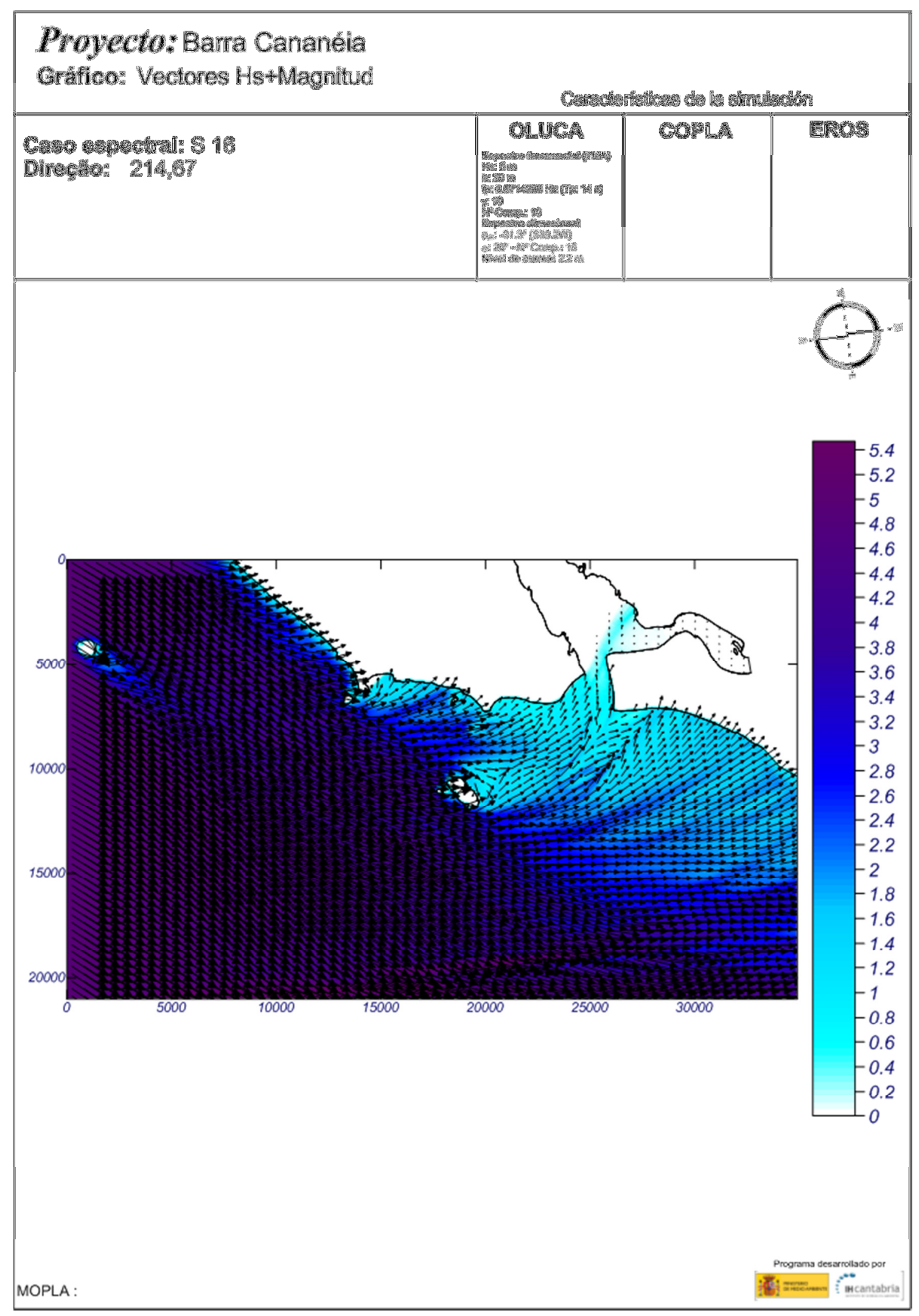

Figura B17: Resultados da propagação do Caso S 16. 


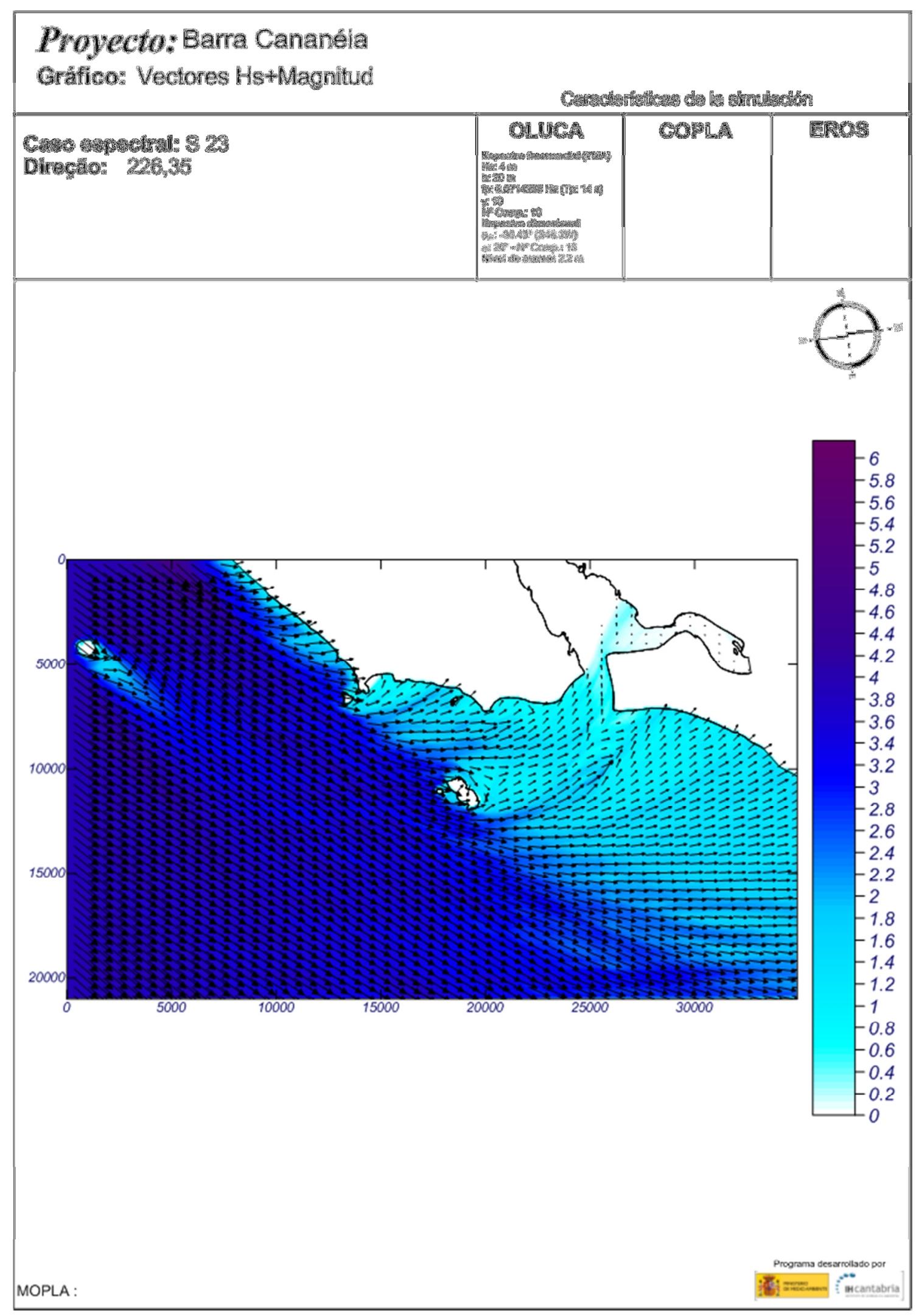

Figura B18: Resultados da propagação do Caso S 23. 